\title{
The Occurrence of East Texas Caddo Ceramic Vessel Sherds in Central Texas Archaeological Region Sites, ca. A.D. 900 to the late 18th Century
}

Timothy K. Perttula

Heritage Research Center, Stephen F. Austin State University

Follow this and additional works at: https://scholarworks.sfasu.edu/ita

Part of the American Material Culture Commons, Archaeological Anthropology Commons, Environmental Studies Commons, Other American Studies Commons, Other Arts and Humanities Commons, Other History of Art, Architecture, and Archaeology Commons, and the United States History Commons

Tell us how this article helped you.

This Article is brought to you for free and open access by the Center for Regional Heritage Research at SFA ScholarWorks. It has been accepted for inclusion in Index of Texas Archaeology: Open Access Gray Literature from the Lone Star State by an authorized editor of SFA ScholarWorks. For more information, please contact cdsscholarworks@sfasu.edu. 


\section{The Occurrence of East Texas Caddo Ceramic Vessel Sherds in Central Texas Archaeological Region Sites, ca. A.D. 900 to the late 18th Century}

\section{Creative Commons License}

\section{(c) (1) \&}

This work is licensed under a Creative Commons Attribution-NonCommercial 4.0 International License 


\section{The Occurrence of East Texas Caddo Ceramic Vessel Sherds in Central Texas Archaeological Region Sites, ca. A.D. 900 to the late $18^{\text {th }}$ Century}

Timothy K. Perttula, with contributions by David Glen Robinson

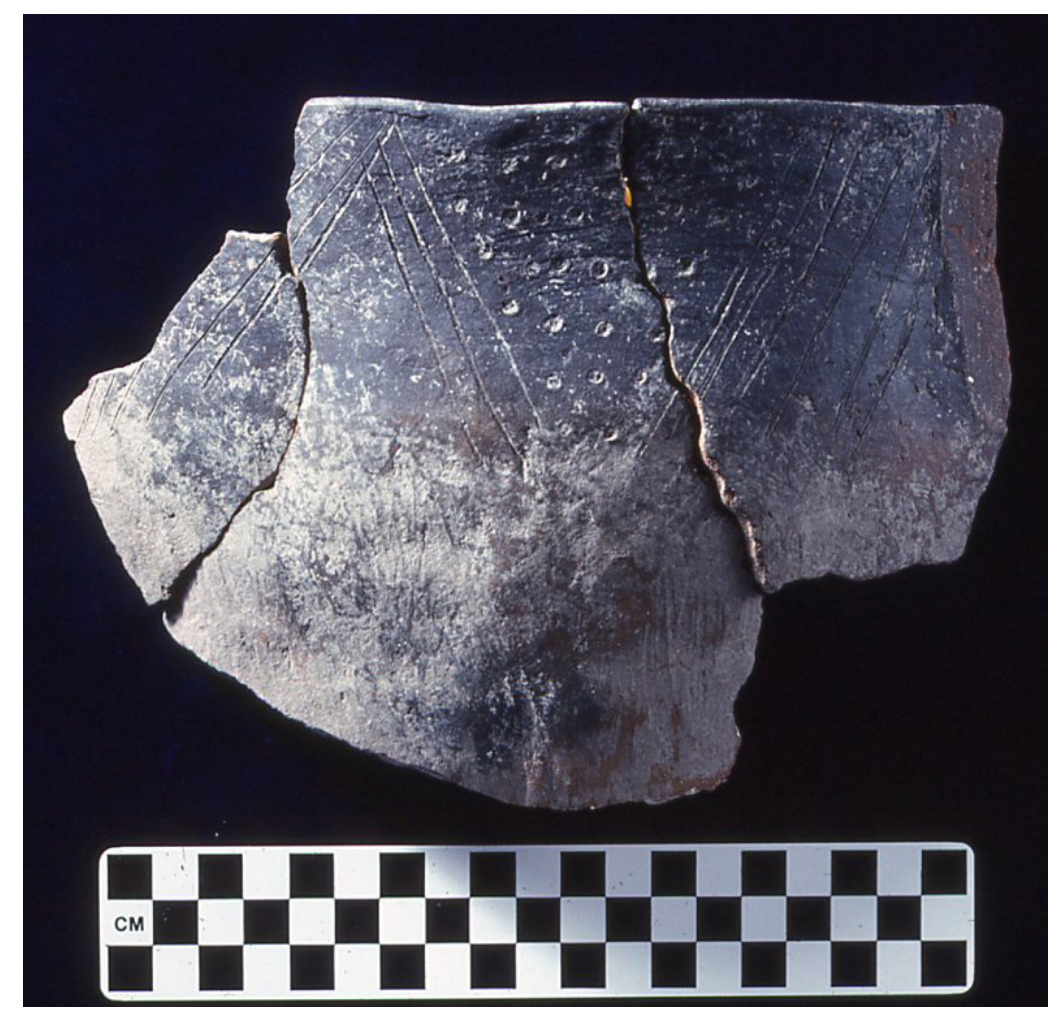

Special Publication No. 47

Friends of Northeast Texas Archaeology, Austin and Pittsburg 
Friends of Northeast Texas Archaeology Editor, Timothy K. Perttula 10101 Woodhaven Dr.

Austin, Texas 78753

tkp4747@aol.com

Friends of Northeast Texas Archaeology, Distribution, Bo Nelson, 344 CR 4154

Pittsburg, Texas 75686

RBoNelson@aol.com

Cover art: Maydelle Incised rim sherd from 41BC73. Image courtesy of Thomas R. Hester 


\section{Table of Contents}

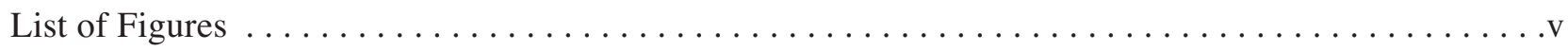

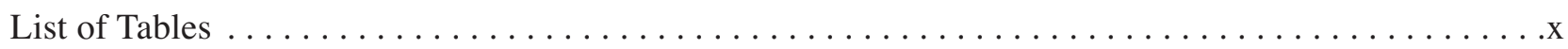

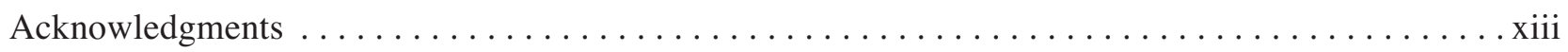

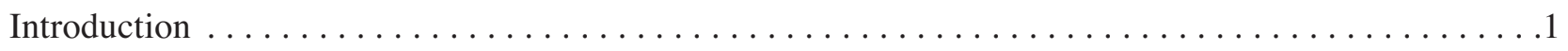

County by County Descriptions of Sites in Central Texas with Ancestral Caddo Ceramics

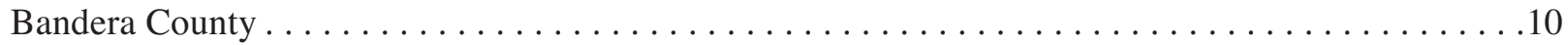

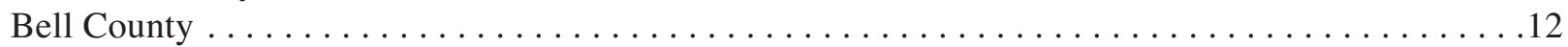

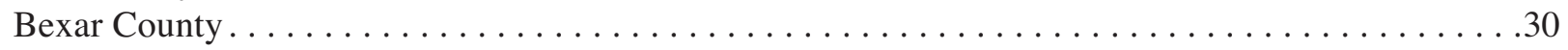

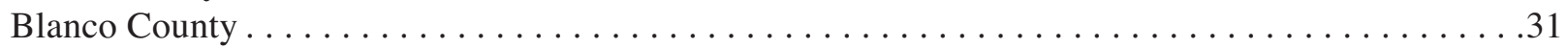

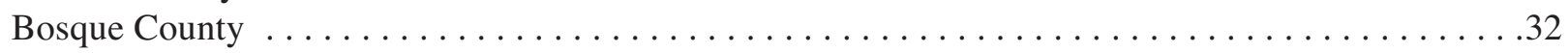

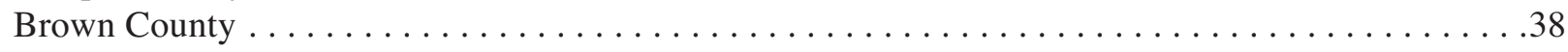

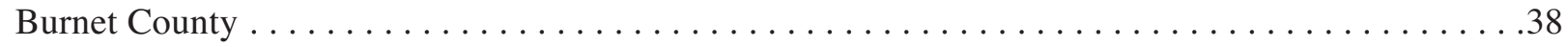

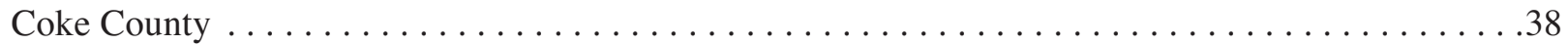

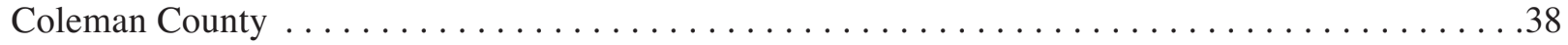

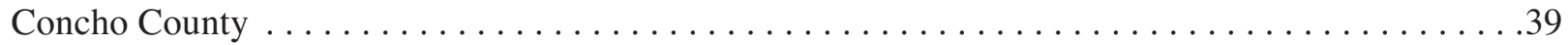

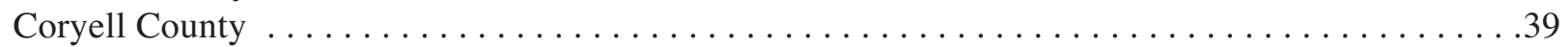

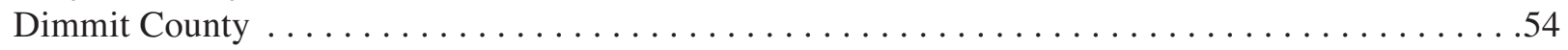

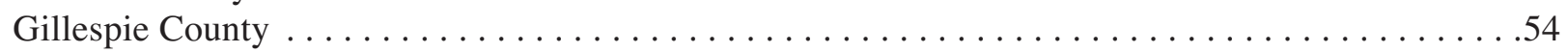

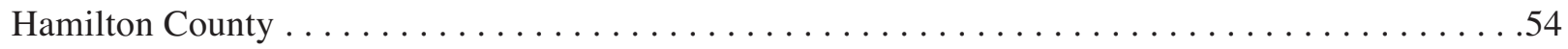

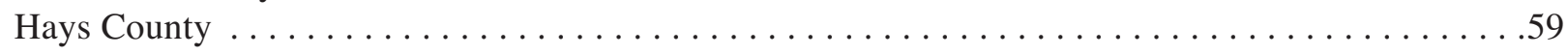

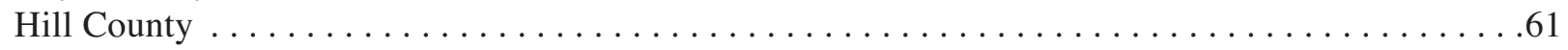

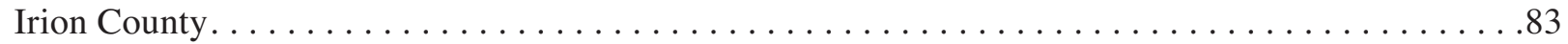

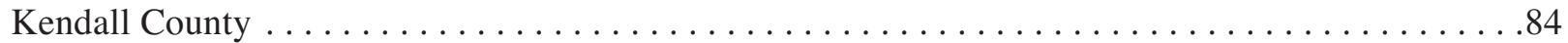

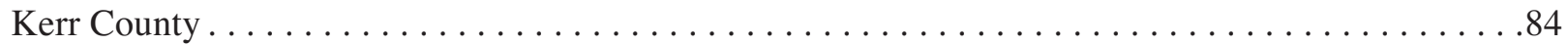

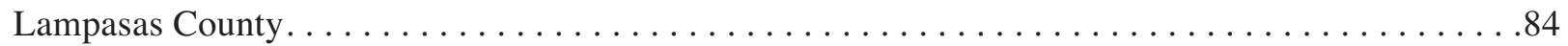

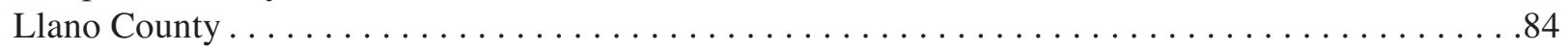

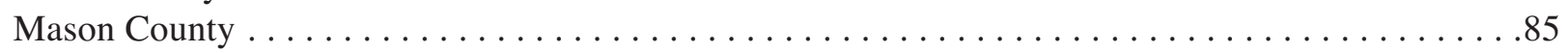

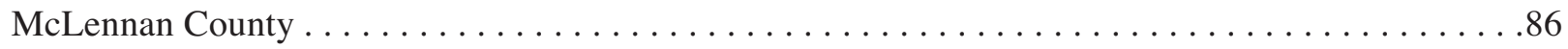

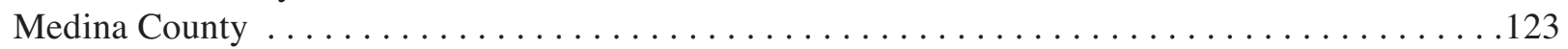

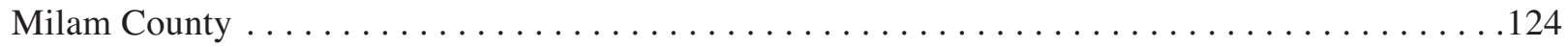

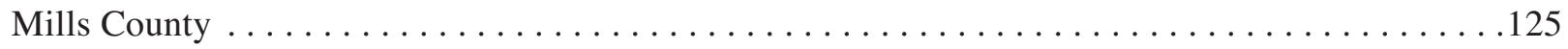

Nolan County. . . . . . . . . . . . . . . . . . . . . . . . . . . . . 126

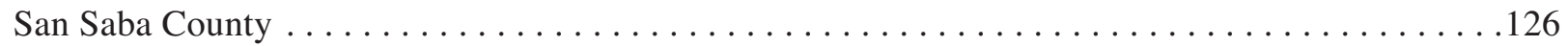

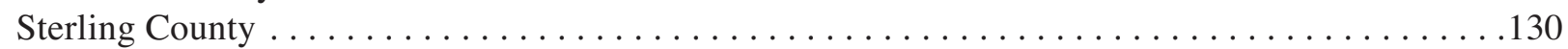

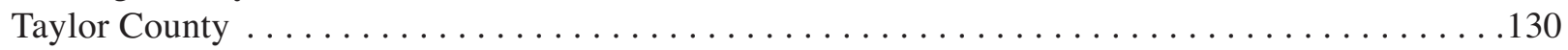

Tom Green County. . . . . . . . . . . . . . . . . . . . . . . . . . . . . . 131

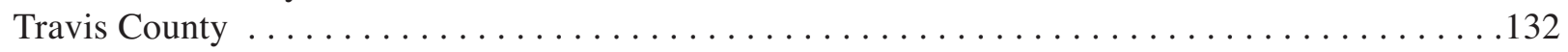

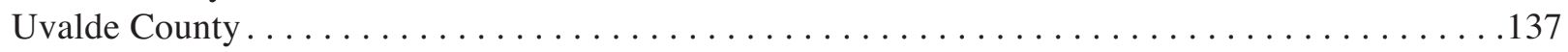

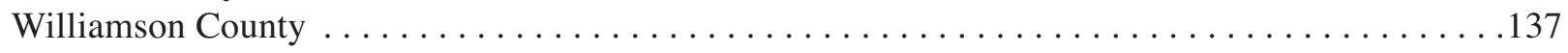


Summary and Synthesis . . . . . . . . . . . . . . . . . . . . . . . . . . . . . . 149

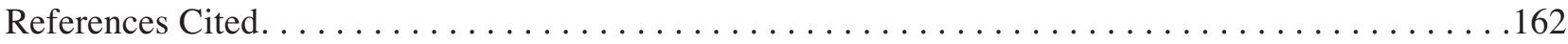

Appendix 1, Megascopic and Ceramic Petrographic Analysis of a Prehistoric Caddo Sherd from Williamson County, Texas

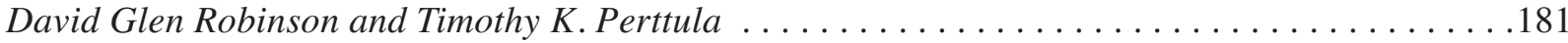




\section{The Occurrence of East Texas Caddo Ceramic Vessel Sherds in Central Texas}

\section{List of Figures}

Figure 1. The Caddo archeological area and the Central Texas area counties that have sites with Caddo ceramic vessel sherds, on map showing natural regions of Texas. Figure prepared by Lance Trask. . . . .2

Figure 2. The Caddo archeological area and the number of sites and/or collections in Central Texas area counties that have sites with Caddo ceramic vessel sherds. Figure prepared by Lance Trask. . . . . . . . 3

Figure 3. Maydelle Incised sherd from an unreported site in Bandera County, Texas. . . . . . . . . . 10

Figure 4. Brushed-incised body sherd from the Shirley Nedry collection, Bandera County, Texas.. . . .12

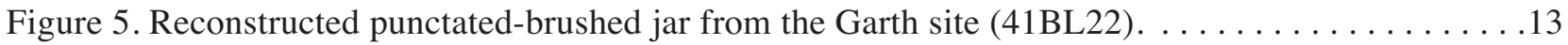

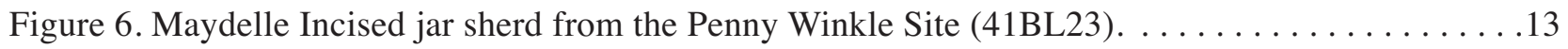

Figure 7. Distribution of ceramic sherds in the excavations at the Bowmer site . . . . . . . . . 17

Figure 8. Decorative elements represented among the engraved sherds at the Bowmer site: a-d, Vessel 1; e, another engraved vessel. Provenience: a, N1005 E1007, Surface to 99.75 m; b, N1004 E1007, 99.80-99.75 m; c, N1001 E1007, 99.70-99.65 m; d, N1006 E1005, 99.90-99.85 m; e,

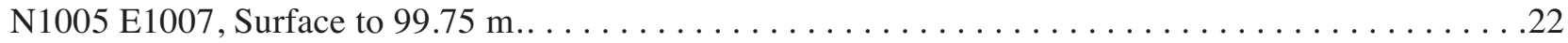

Figure 9. Distribution of engraved sherds at the Bowmer site $\ldots \ldots \ldots \ldots \ldots \ldots \ldots \ldots \ldots \ldots$

Figure 10. Distribution of brushed and brushed-incised sherds at the Bowmer site (41BL116) . . . .25

Figure 11. Clusters of Caddo sites with high proportions (>than 40 percent) of bone-tempered sherds

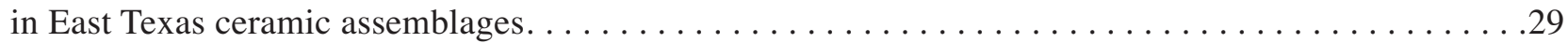

Figure 12. Decorative elements on Maydelle Incised rim sherd from Stealth Cave (41BX1253). . . . .31

Figure 13. Maydelle Incised rim sherd from 41BC73. Image courtesy of Thomas R. Hester. . . . . . .31

Figure 14. Cross-hatched incised sherds from Horn Shelter $\# 2$ (41BQ46) $\ldots \ldots \ldots \ldots \ldots \ldots \ldots$

Figure 15. Bivariate plot of chromium and potassium (log base-10 ppm) showing the relationship between the main CT reference groups and the new samples from 41BQ285. The new samples are individually plotted. Ellipses represent $90 \%$ confidence intervals for membership in the groups. . . . 35

Figure 16. Location of the Grimes-Houy Shelter, Grimes-Houy Burned Rock Midden, and Ament Midden sites on the Leon River in Coryell County, Texas.. . . . . . . . . . . . . . . . . . . . 40

Figure 17. Weches Fingernail Impressed sherds from the Grimes-Houy Burned Rock Midden site. . . .43

Figure 18. Selected decorative elements on utility ware sherds from the Grimes-Houy Burned Rock

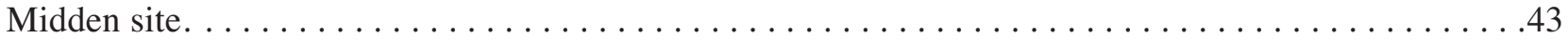


Figure 19. Selected decorative elements on fine ware sherds from the Grimes-Houy Burned Rock

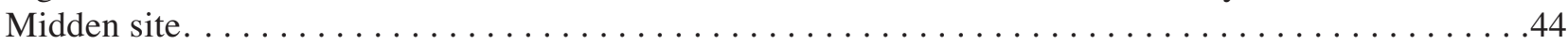

Figure 20. Elbow pipe bowl rim sherd from the Grimes-Houy Burned Rock Midden site. . . . . . . . .45

Figure 21. Location of the Urbankte site in the Leon River basin in Coryell County, Texas. . . . . . . .45

Figure 22. Early Caddo period ceramic sherds from the Urbankte site $\ldots \ldots \ldots \ldots \ldots \ldots \ldots \ldots$

Figure 23 . Engraved body sherd from the Urbankte site. $\ldots \ldots \ldots \ldots \ldots \ldots \ldots \ldots \ldots \ldots \ldots$

Figure 24. Decorative elements on incised body sherd from the Ament Midden site. . . . . . . . . 48

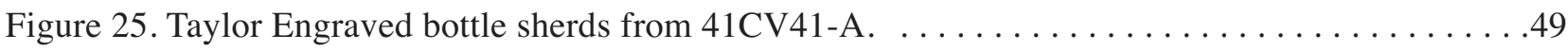

Figure 26. Decorative elements on engraved rim sherd from unreported site near $41 \mathrm{CV} 92 \ldots \ldots \ldots .50$

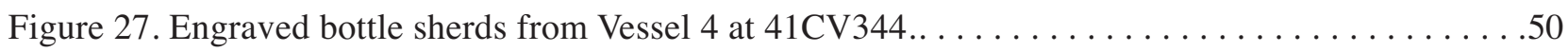

Figure 28. Hume Engraved bottle sherds from the Chrisner's Ranch site: a, photo image; b, drawing

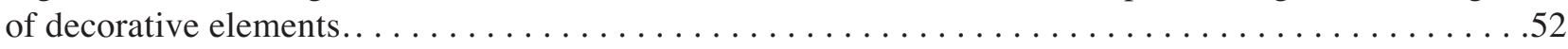

Figure 29. Maydelle Incised sherd from the Chrisner's Ranch site $\ldots \ldots \ldots \ldots \ldots \ldots \ldots \ldots \ldots . .52$

Figure 30. Decorated sherds from the Frank Simmons/McLeod Farm in Coryell County, Texas. . . . . .53

Figure 31. Maydelle Incised jar rim sherd from 41DM134. Image provided courtesy of Thomas R.

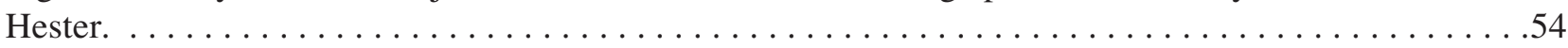

Figure 32. The distribution of areas in East Texas with high proportions of brushed Caddo ceramic

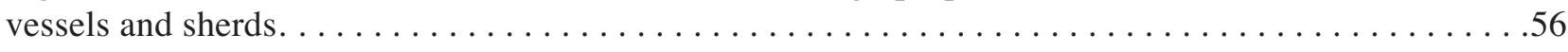

Figure 33. Decorative elements on selected sherds from the Blum Rockshelter site............63

Figure 34. Weches Fingernail Impressed sherds from the Lavender site (41HI30) in Hill

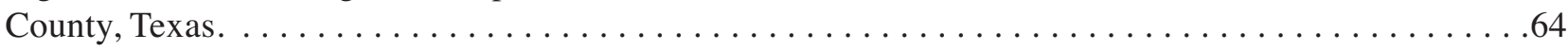

Figure 35. Selected decorative elements on utility ware and fine ware sherds from the Sour Mash

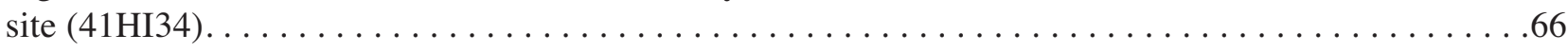

Figure 36. Selected decorated sherds from 40A5-11/15 in Hill County, Texas. . . . . . . . . . . .71

Figure 37. Decorative elements on Dunkin Incised vessel sherd from Site 375 in the Frank Bryan

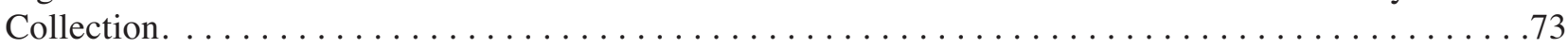

Figure 38. Decorative elements on an engraved sherd from Site 383 in the Frank Bryan Collection... .74

Figure 39. Decorative elements on incised rim sherd from Site 384 in the Frank Bryan Collection. . . .75 
Figure 40. Decorative elements on engraved sherds from Site 391 in the Bryan Collection. . . . . . . .77

Figure 41. Decorative elements on Pennington Punctated-Incised rim sherd from Site 392 . . . . . . 77

Figure 42. Decorative elements on sherds from Site 393 in the Bryan Collection... . . . . . . . . . .78

Figure 43. Selected decorative elements on sherds from Site 377 in the Bryan Collection......... .82

Figure 44. Selected decorative elements on sherds from Site 390 in the Bryan Collection. . . . . . . .83

Figure 45. Decorative elements on Maydelle Incised rim sherd from 41LL76 $\ldots \ldots \ldots \ldots \ldots$

Figure 46. Maydelle Incised rim sherd from 41LL415. Photograph courtesy of Charles Hixson. . . . . .85

Figure 47. Womack Engraved sherds in the Watt-Redder collection from the Stone site (41ML38)... .91

Figure 48. Brushed vessel sherds in the Watt-Redder collection from the Stone site (41ML38).. . . .992

Figure 49. Selected decorated sherds from the Clark site in the Frank Watt Collections... . . . . . . .96

Figure 50. Decorative elements on sherds from the Clark site (41ML39): a, brushed rim; b, incised-

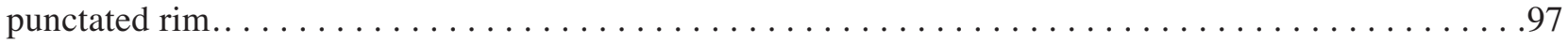

Figure 51. Decorative elements on Hood Engraved, var. Hood bowl from the Cement Hill site. . . . . 998

Figure 52. Location of the Chupik site (41ML44) in the Brazos River floodplain, based on

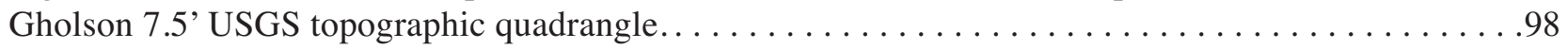

Figure 53. Ceramic artifact clusters at the Chupik site $(41 \mathrm{ML} 44) \ldots \ldots \ldots \ldots \ldots \ldots \ldots \ldots \ldots$

Figure 54. Selected decorative elements on utility ware sherds from the Chupik site (41ML44):

a, body sherd with diagonal opposed fingernail punctated rows; b-g, incised rim and body sherds. . . 103

Figure 55. Weches Fingernail Impressed rim and body sherds from the Chupik site (41ML44). . . . .104

Figure 56. Selective decorative elements on incised-punctated utility ware sherds from the Chupik

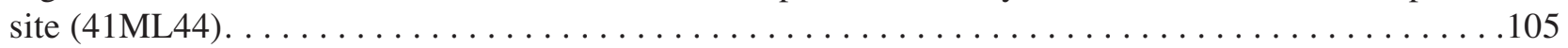

Figure 57. Selected engraved decorative elements in the fine ware sherds from the Chupik site

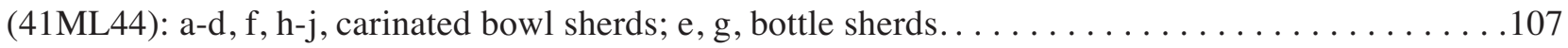

Figure 58. Selected decorated sherds from the Asa Warner site in the Mayborn Museum Complex

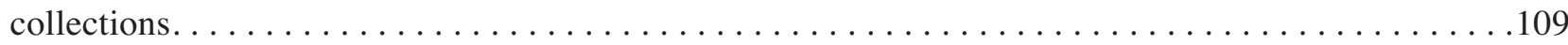

Figure 59. Decorative elements on selected utility ware sherds from the Asa Warner site (41ML46): a, cross-hatched incised body sherd; b, Dunkin Incised body sherd; c, Kiam Incised rim sherd;

d, incised-punctated body sherd. 
Figure 60. Decorative elements on selected fine ware sherds from the Asa Warner site (41ML46): a, opposed engraved rim sherd; b, cross-hatched engraved zone body sherd; c-d, body sherds with hatched zones and panels; e-f, engraved-punctated bottle body sherds; g, engraved bottle sherd. . . . .113

Figure 61. Pinched decorative elements of the large jar from the Cement Hill 2 site (41ML66).. . . . .114

Figure 62. Appliqued decorative element on the large jar from the Cement Hill 2 site...........115

Figure 63. Decorative elements on a reconstructed drawing of the large jar from the Cement Hill 2 site. . . . . . . . . . . . . . . . . . . . . . . . . . . . . . . . . . . . . . . . . 115

Figure 64. Fingernail punctated body sherd from the Warner \#1 site (39D3-1) in McLennan County,

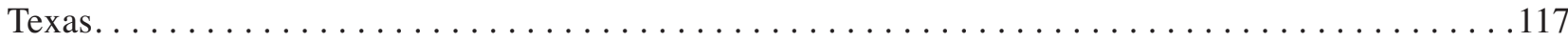

Figure 65. Selected decorated sherds from the Warner \#11 site, McLennan County, Texas. . . . . . . 118

Figure 66. Selected decorated sherds from the Warner \#12 site in McLennan County, Texas.. . . . . . 119

Figure 67. Engraved sherds from the Warner \#12 site in the Mayborn Museum Complex collections. .120

Figure 68. Fingernail punctated sherds from the Tarpley site $(41 \mathrm{ME} 147) \ldots \ldots \ldots \ldots \ldots \ldots \ldots \ldots$

Figure 69. Horizontal and vertical incised sherds from Vessel 3 at the Tarpley site (41ME147)......123

Figure 70. Lower rim and body sherds from a Dunkin Incised vessel in the Victor Turner collection from Milam County. Photograph courtesy of Thomas R. Hester. . . . . . . . . . . . . . . . . . . 125

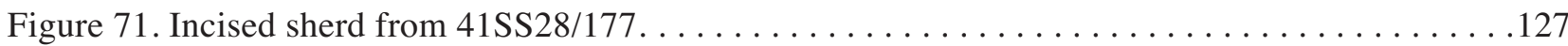

Figure 72. Plain grog-tempered body sherd from 41SS28/177: a cross-section; b, vessel sherd

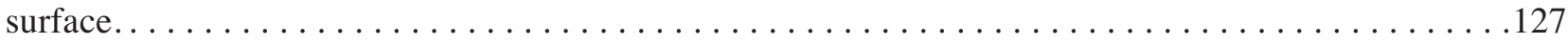

Figure 73. Engraved bottle sherd from the Baker site (41SS192). Photo provide courtesy of Charles Hixson. . . . . . . . . . . . . . . . . . . . . . . . . . . . . . . . . . . . . . . . 129

Figure 74. Selected decorative elements on ancestral Caddo ceramic sherds from 41TA123 . . . . . 130

Figure 75 . Decorative elements on Patton Engraved body sherd from $41 \mathrm{TG} 45 \ldots \ldots \ldots \ldots \ldots \ldots$

Figure 76. Brown painted rim sherd with brown painted bands and a loop handle from the Collins

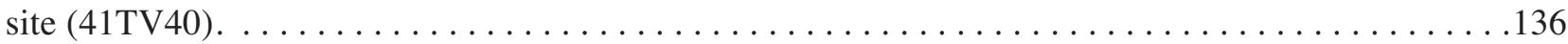

Figure 77. Decorative elements on a Patton Engraved body sherd from the Cedar Park Mound site. . .137

Figure 78. Decorative elements on Holly Fine Engraved vessel sherds from the Cluck Spring site,

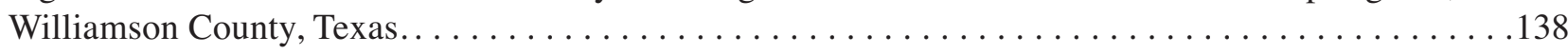

Figure 79. Vessel 1 from the Barker site (from Sorrow 1970:Figure 5) and brushed-incised body

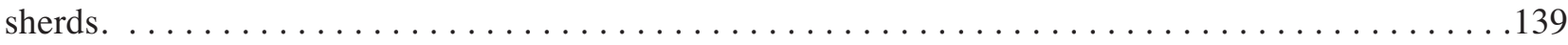


Figure 80. Decorative elements on engraved carinated bowl rim sherd from the Loeve site (41WM133).

Figure 81. Reconstructed form for Vessel 1 at the Rowe Valley site (41WM437). after Perttula et al.

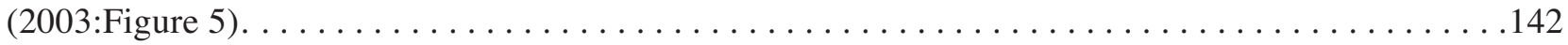

Figure 82. Photographs of sections of Vessel 1: a, rim section; b, rim-body section; c, lower rim-body section. Courtesy of Lauren Bussiere, Texas Archeological Research Laboratory, The University of Texas at Austin. . . . . . . . . . . . . . . . . . . . . . . . . . . . . . . . 143

Figure 83. Decorative elements on Patton Engraved vessel from the Rowe Valley site (Vessel 2,

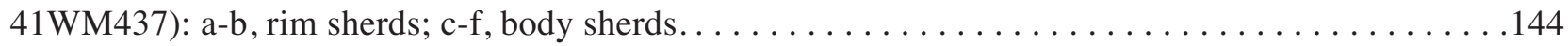

Figure 84. Reconstructed vessel form for Vessel 3 at the Rowe Valley site (41WM437), after

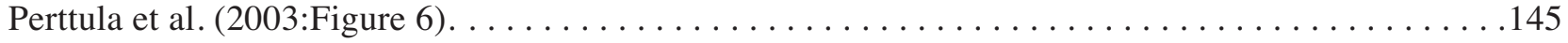

Figure 85 . Fingernail punctated sherd from $41 \mathrm{WM} 763 \ldots \ldots \ldots \ldots \ldots \ldots \ldots \ldots \ldots \ldots \ldots \ldots$

Figure 86. Holly Fine Engraved bottle sherd from a site in Williamson County, Texas, found by Darrell

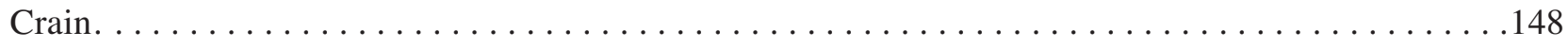

Figure 87. Distribution of sites with Mossy Grove culture Goose Creek Plain, var. unspecified

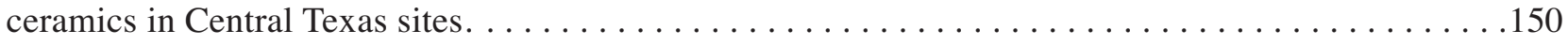

Figure 88. Woodland period sites and cultures in East and Southeast Texas (from Ellis 2013).......151

Figure 89. Distribution of sites with ca. A.D. 900-1200 ancestral Caddo ceramics in Central

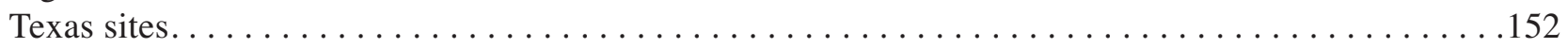

Figure 90. Distribution of sites with ca. A.D. 1200-1400 ancestral Caddo ceramics in Central Texas

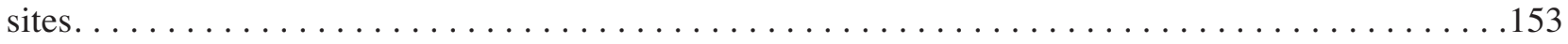

Figure 91. Distribution of sites with ca. A.D. 1400-1680 ancestral Caddo ceramics in Central Texas

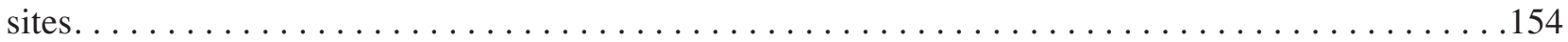

Figure 92. Distribution of recognized Late Caddo period phases in East Texas and the southern

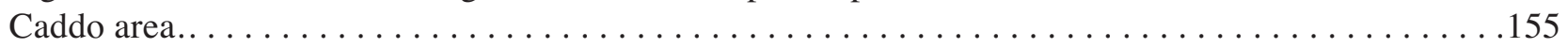

Figure 93. Distribution of sites with ca. post-A.D. 1680 ancestral Caddo ceramics in Central Texas

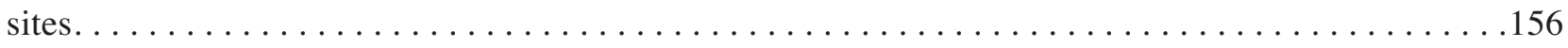

Figure 94. Historic Caddo phases and locales with Historic Caddo settlements in East Texas. . . . . . . 157 


\section{List of Tables}

Table 1. Sites likely with Caddo ceramics in the Central Texas region, continued. . . . . . . . . . 4

Table 2. Shirley Nedry Sherd Collection from Bandera County, Texas . . . . . . . . . . . . . .11

Table 3. Provenience of the ceramic sherds from the Bowmer site (41BL116) . . . . . . . . 15

Table 4. Detailed analysis of the ceramic sherds from the Bowmer site $(41 \mathrm{BL} 116) \ldots \ldots \ldots \ldots \ldots$

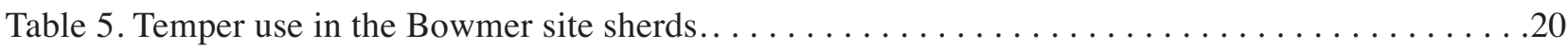

Table 6. Surface treatment on the sherds from the Bowmer site $(41$ BL116) $\ldots \ldots \ldots \ldots \ldots \ldots$

Table 7. Firing conditions of the sherds from the Bowmer site $(41 \mathrm{BL} 116) \ldots \ldots \ldots \ldots \ldots \ldots \ldots$

Table 8 . Mean thickness of the body wall of the Bowmer site (41BL116) sherds. . . . . . . . 27

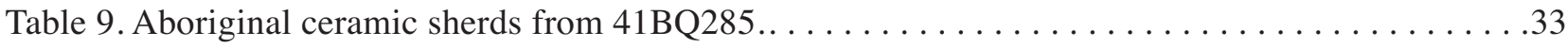

Table 10. Ceramic sherds from the Grimes-Houy Burned Rock Midden site (41CV21)... . . . . . . .41

Table 11. Decorative methods and elements represented in the utility ware and fine ware sherds from the Grimes-Houy Burned Rock Midden $(41 \mathrm{CV} 21) \ldots \ldots \ldots \ldots \ldots \ldots \ldots \ldots \ldots \ldots \ldots$

Table 12. Ceramic artifacts from the Urbankte site (41CV26) in the TARL collections. ..........46

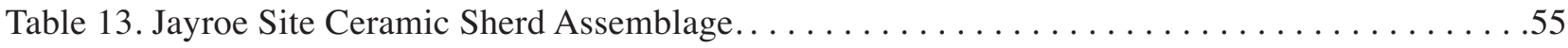

Table 14. Caddo ceramic wares at the Blum Rockshelter $(41 \mathrm{HI} 8) \ldots \ldots \ldots \ldots \ldots \ldots \ldots \ldots \ldots \ldots$

Table 15. Decorative methods and elements in the utility ware and fine ware sherds from the Blum

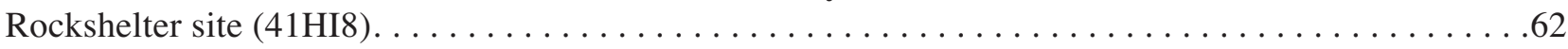

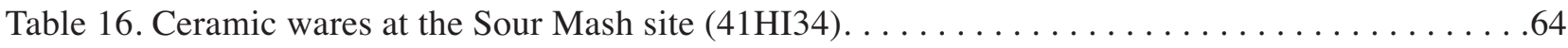

Table 17. Decorative methods and elements in the utility ware and fine ware sherds from the

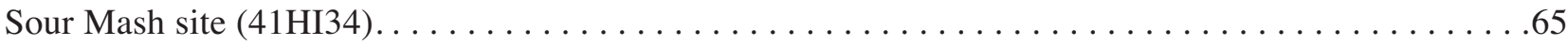

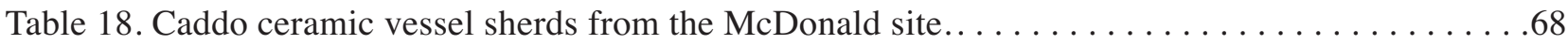

Table 19. Ceramic sherds from 40 A5-11/15 in Hill County, Texas. . . . . . . . . . . . . . .71

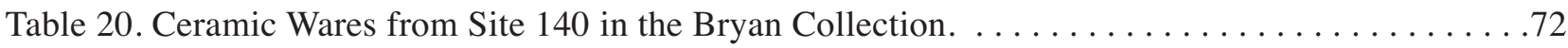

Table 21. Ceramic Wares from Site 372 in the Bryan Collection. . . . . . . . . . . . . . 72

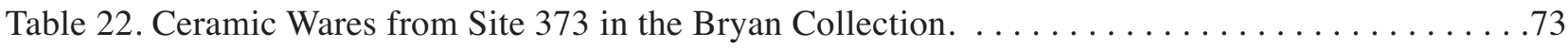




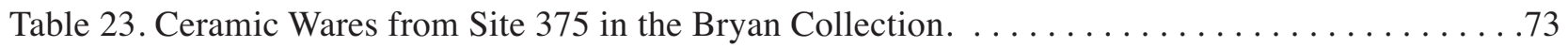

Table 24. Ceramic Wares from Site 377 in the Bryan Collection. . . . . . . . . . . . . . . .74

Table 25. Ceramic Wares from Site 383 in the Bryan Collection. . . . . . . . . . . . . . .74

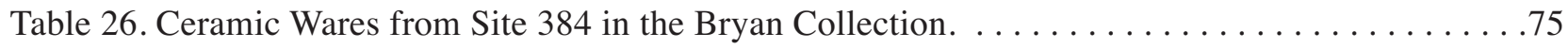

Table 27. Ceramic Wares from Site 385 in the Bryan Collection. . . . . . . . . . . . . . . 75

Table 28. Ceramic Wares from Site 386 in the Bryan Collection. . . . . . . . . . . . . . .75

Table 29. Ceramic Wares from Site 387 in the Bryan Collection. .................... 76

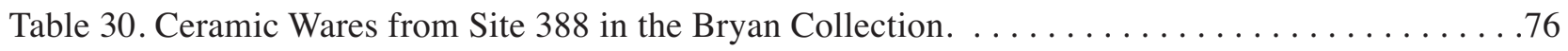

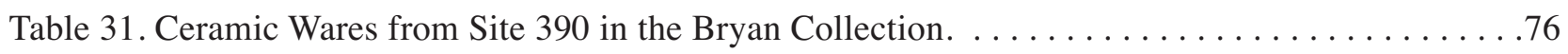

Table 32. Ceramic Wares from Site 391 in the Bryan Collection. . . . . . . . . . . . . . . . 77

Table 33. Ceramic Wares from Site 392 in the Bryan Collection. . . . . . . . . . . . . . . .77

Table 34. Ceramic Wares from Site 393 in the Bryan Collection. . . . . . . . . . . . . . . 78

Table 35. Decorative methods and elements in the Site 377 ceramic assemblage. . . . . . . . . . . .79

Table 36. Decorative methods and elements in the Site 390 ceramic assemblage.............80

Table 37. Ceramic sherds from the Watt and Redder collections from the Stone site (41ML38).. . . .87

Table 38. Temper categories in Wichita Indian sites in Texas and Oklahoma . . . . . . . . . . 88

Table 39. Decorative methods and elements on the decorated sherds from the Stone site ceramic

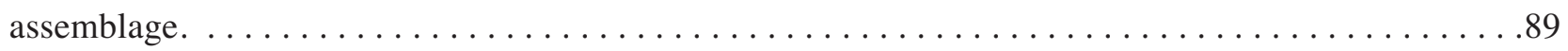

Table 40. Ceramic wares in the TARL collection from the Stone site $(41 \mathrm{ML} 38) \ldots \ldots \ldots \ldots \ldots$

Table 41. Decorative methods represented in $18^{\text {th }}$ century Wichita sites in Oklahoma and Texas......94

Table 42. Frank Watt Collection from the Clark site (41ML39) in the Mayborn Museum Complex

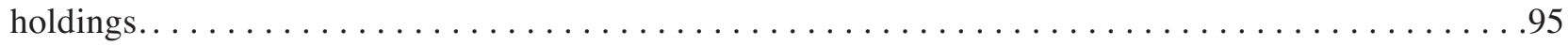

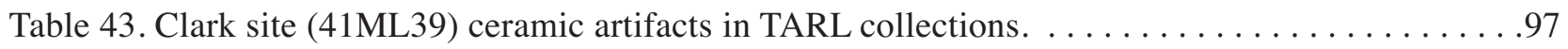

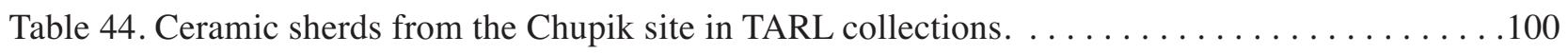

Table 45. Decorative methods and elements in utility ware sherds from the Chupik site (41ML44)... 101

Table 46. Decorative methods and elements in fine ware sherds from the Chupik site (41ML44). . . 105 
Table 47. Ceramic sherds from the Asa Warner site (41ML46) in the TARL collections. . . . . . . . . 109

Table 48. Decorative methods and elements in utility ware and fine ware sherds in the TARL

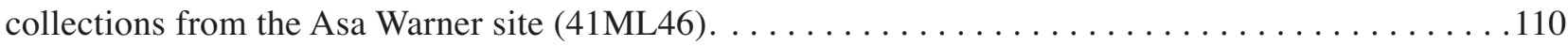

Table 49. Sherd sample from the Warner \#1 site, McLennan County, Texas. . . . . . . . . . . . . . 116

Table 50. Sherd sample from the Warner \#11 site, McLennan County, Texas. . . . . . . . . . . . . 117

Table 51. Sherd sample from the Warner \#12 site, McLennan County, Texas. . . . . . . . . . . . . . . . 119

Table 52. K. H. Aynesworth Collection from McLennan County, Texas. . . . . . . . . . . . . . . 121

Table 53. Caddo ceramic sherds from the Hughes site on Aquilla Creek, McLennan County, Texas. . .122

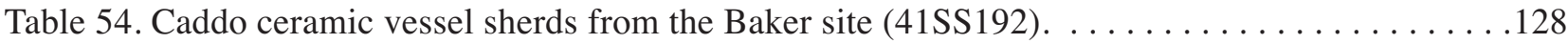

Table 55. Ancestral Caddo ceramic vessel sherds from 41TA123 . . . . . . . . . . . . . . . . 130

Table 56. Ancestral Caddo ceramic vessel sherds from $41 \mathrm{TV} 5 \ldots \ldots \ldots \ldots \ldots \ldots \ldots \ldots \ldots \ldots \ldots \ldots$

Table 57. Ancestral Caddo wares at the Collins site $(41 \mathrm{TV} 40) \ldots \ldots \ldots \ldots \ldots \ldots \ldots \ldots \ldots \ldots \ldots$

Table 58. Ancestral Caddo utility ware decorative methods and elements from the Collins site

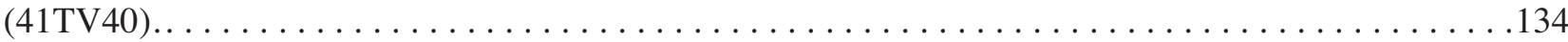

Table A-1. Color recordings using Munsell Soil Color charts of the Williamson County sherd. . . . . 183

Table A-2. Ceramic petrography of a Williamson County Caddo sherd: proportions of a 200

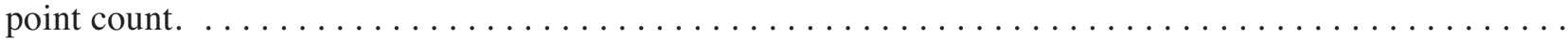
183 


\section{Acknowledgments}

First and foremost, I want to thank Brett Cruse of the Texas Historical Commission. His support for the project has been crucial in bringing it to completion, as is the financial support of the Texas Historical Commission.

There are several institutions and people that I also must thank for their help and assistance in completing this project. Foremost, the staff at the Texas Archeological Research Laboratory at The University of Texas at Austin (TARL) and the Mayborn Museum Complex at Baylor University opened their collections for my examination, and I especially thank Marybeth Tomka and Lauren Bussiere of TARL and Sabrina Thomas and Anita Benedict at the Mayborn Museum Complex.

Colleagues shared information and photo images, as well as pointed me towards sites with ceramics that warranted consideration in this study. They include Thomas R. Hester, Harry J. Shafer, Edward B. Jelks, Karl Kibler, Andy Malof, Carey Weber, Eric Schroeder, Richard Drass, Sarah Trabert, Charles Hixson, and Dan Prikryl. Dan, in particular, was of great help in obtaining sherd collections on loan from the Mayborn Museum Complex at Baylor University. Heath Bentley and Julian A. Sitters, both of AmaTerra Environmental, Inc., located a report at TARL on a site in Mills County with ancestral Caddo ceramics, and they were gracious enough to provide me with a PDF of the 1974 report. I also appreciate the opportunity provided by Elton Prewitt to study the interesting ceramic vessel sherds from the Rowe Valley site (41WM437), and to include their analysis in this study.

Several avocational archeologists also shared information on ceramic sherds of probable ancestral Caddo origin they have found on Central Texas sites, and allowed me to document them and include the findings in this study. They include Darrell Crain, Buddy Whitley, and Marcus Whittle.

I also thank Shirley Nedry for her permission to analyze the sherds in her collection from Bandera County, Texas. I also appreciate the help of Stephen Bishop, Texas Historical Commission Archeology Steward, for coordinating the study of the Nedry collection, providing notes and sherd photographs from Texas Parks \& Wildlife Department archaeologists on the sherds, and for mailing the sherds to me for examination.

The figures and photographs in this report were prepared by a number of people, particularly by Lance Trask. Others were provided by Lauren Bussiere, Sandy Hannum, Thomas R. Hester, Charles Hixson, Harry J. Shafer, Darrell Crain, and Buddy Whitley. The formatting and printing of this report was done by OneTouchPoint in Austin, Texas. 



\section{Introduction}

The development and maintenance of long-distance trade networks for both economic, social, and religious purposes was a notable feature of the ancestral Caddo tradition from its very beginnings, and this includes the Caddo peoples that lived in East Texas. Bison hides, salt, raw materials such as copper, galena, stone, and marine shell, and finished objects such as pottery vessels (and possibly their contents), were part of the trading system.

Much of the archaeological evidence for the Caddo long-distance trade and exchange networks of prestige goods occur in contexts dating from ca. A.D. 800 to 1400, with long-distance trade outside of the East Texas communities seemingly declining after that time. Certainly, the best-known examples of Caddo long-distance exchange are seen in the grave offerings from mound burials from the premier civicceremonial centers like Spiro, Crenshaw, Gahagan, Mounds Plantation, and Mineral Springs in eastern Oklahoma, southwestern Arkansas, and northwestern Louisiana (see Girard et al. 2014), respectively, and George C. Davis (41CE19) in East Texas. Exchanged goods in components dating from ca. A.D. 1000-1300 - the apex of the Caddo's participation in long-distance trade network of prestige goodsinclude a wide variety of prestige goods such as ceramic vessels, ceremonial tools, marine shell gorgets and conchs, shell columella beads, stone pipes, copper masks and repoussé, copper-covered ornaments, and large chert bifaces. However, in the case of ancestral Caddo ceramic vessels, they were also traded and exchanged by Caddo peoples throughout the length of their settlement in East Texas for other kinds of goods as well as to help cement alliances, and this pattern of trade and exchange became especially common after ca. A.D. 1400 between certain parts of East Texas (i.e., the Neches River basin) and Central Texas aboriginal inhabitants, as Krieger (1946:Map 1) had indicated more than 70 years ago.

Evidence of this trade and exchange is clearly denoted by the wide distribution of Caddo ceramic vessels from: Mississippian sites in Missouri, Arkansas, Louisiana, and Alabama; Plains Village sites in the Central and Southern Plains (i.e., the Washita River, Great Bend of the Arkansas River, Great Oasis, and Mill Creek cultures), and among hunting-gathering groups in the Texas Panhandle, Caprock Canyonlands, the La Junta area at the confluence of the Rio Grande and Conchos river (see Kelley 1986:83), mission sites in South Texas and the central Texas Coast with Historic Caddo ceramics from the Neches-Angelina river basins (cf. Lakeman 2001), and Central Texas (see Perttula 2002a). Ceramic petrographic investigations also document the regular intra-regional exchange of ceramic vessels among Caddo groups in East Texas. When the de Soto-Moscoso entrada encountered Caddo groups in East Texas in 1542, and then in later $17^{\text {th }}$ century Spanish entradas (Foster 2008:201-202), the chroniclers did note the presence of cotton and turquoise that must have come from the Southwestern Pueblos (see Krieger 1946), indicating that long-distance Caddo interregional trade and exchange continued into the $16^{\text {th }}$ and late 17th centuries. Further evidence of the continued interregional trade after the late $17^{\text {th }}$ century are sherds from Patton Engraved vessels from La Junta (Kelley 1986).

In this monograph (see also Perttula 2017a, 2017c), I discuss the character of the ceramic vessel sherds found on Central Texas sites, and one site in Dimmit County in southern Texas, that may have been made by Caddo peoples living in East Texas (Figures 1 and 2). These sherds have been the subject primarily of technological and stylistic analysis, but petrographic analysis and instrumental neutron activation analysis has also been done by other researchers for some assemblages. The purpose of these analyses has been to characterize these sherds with respect to their technological, stylistic, petrographic, and geochemical diversity, and also to establish if these sherds are from vessels manufactured locally or extra-locally. Specifically, the concern has been to establish through these various analyses if the sherds from certain Central Texas sites are from aboriginal vessels made in the general vicinity of the site from local clays, were made in other parts of Central Texas, or are sherds from vessels made in the Caddo area of East Texas. 
At the present time, there are 34 counties in the overall region with sites that are likely to have Caddo ceramic vessel sherds (Figure 1 and Table 1), based on published descriptions, macroscopic analyses, and petrographic/chemical analyses. These counties are in the Blackland Prairie, Edwards Plateau, Llano Uplift, the southern part of the Rolling Plains, and the South Texas Brush Country. Most of the known sites and/or collections occur in the Blackland Prairie and Edwards Plateau in the Brazos River and Leon River basins. Of the 163 known sites and/or collections identified to date (Table 1), 16.6 percent are in McLennan County, another 14.7 percent are in Hill County, 13.5 percent are in Coryell County, 8.6 percent are in Williamson County, and 6.1 percent are in Bell County (Figure 2).

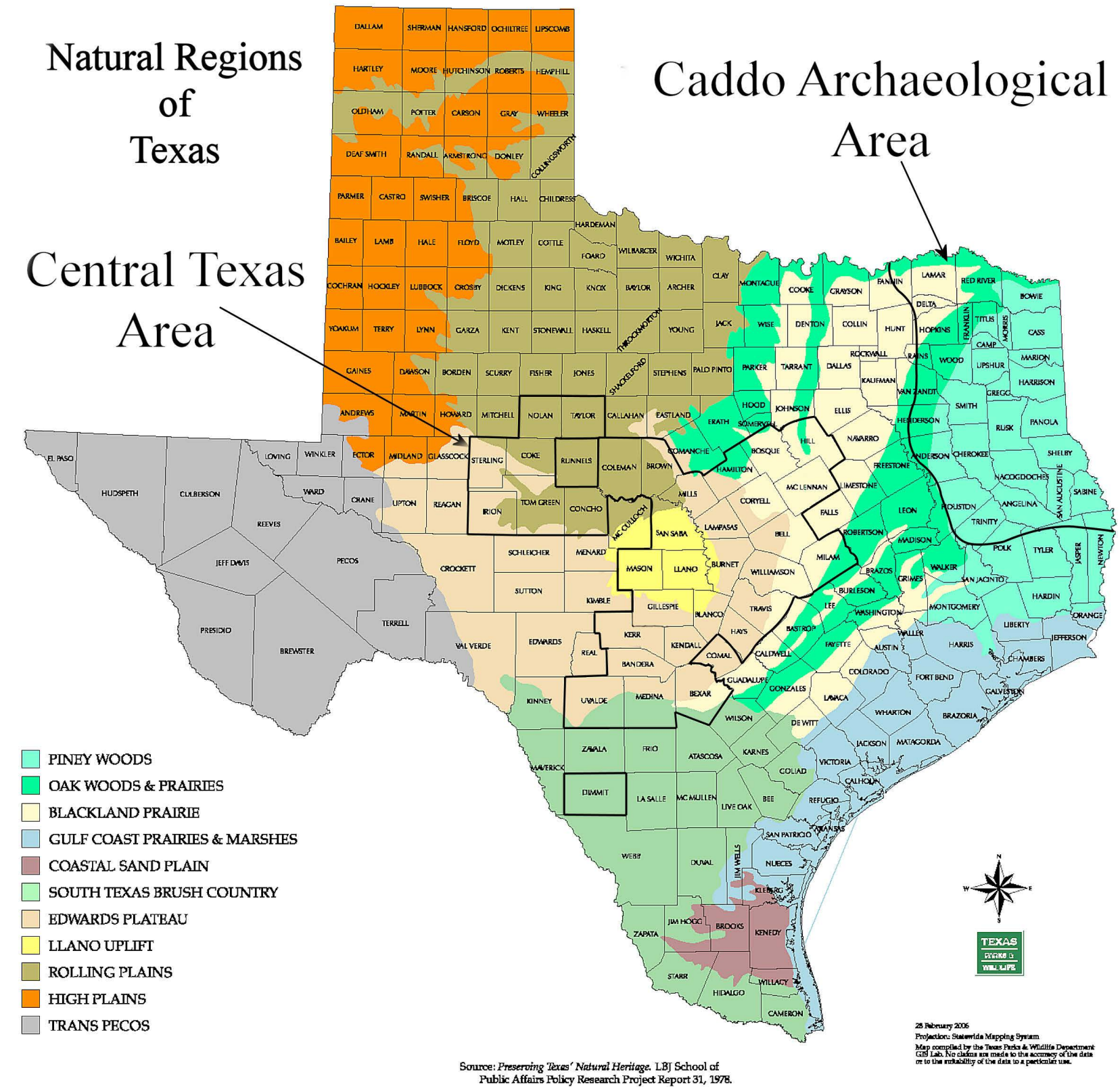

Figure 1. The Caddo archeological area and the Central Texas area counties that have sites with Caddo ceramic vessel sherds, on map showing natural regions of Texas. Figure prepared by Lance Trask. 


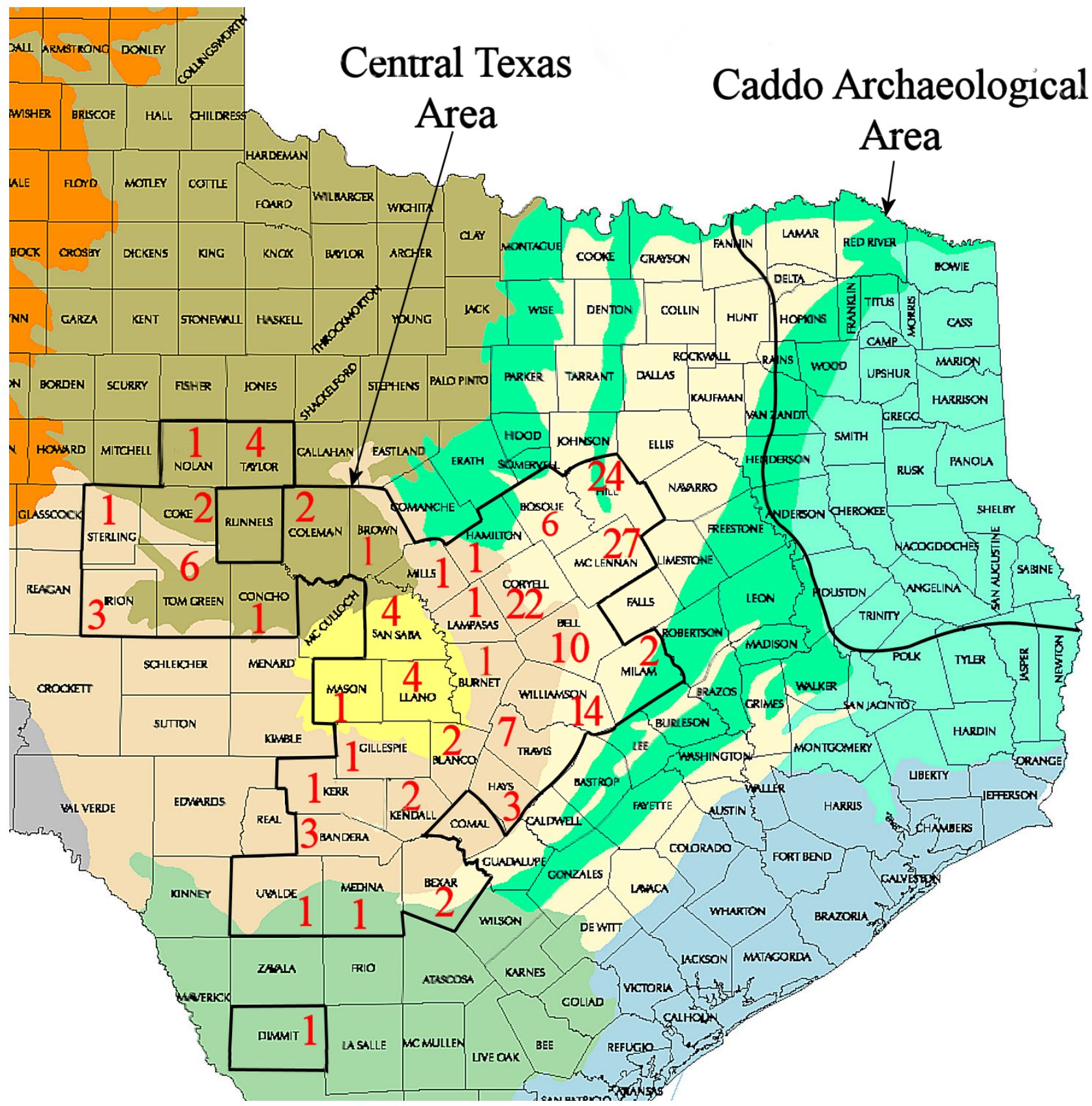

Figure 2. The Caddo archeological area and the number of sites and/or collections in Central Texas area counties that have sites with Caddo ceramic vessel sherds. Figure prepared by Lance Trask.

Table 1. Sites likely with Caddo ceramics in the Central Texas region.

Site Number Site Name

Bandera

41BN33

No Trinomial

No Trinomial
Rainey

Paul Olsen Collection

Shirley Nedry Collection
References

Henderson 2001

T. R. Hester, 2011 personal communication

Stephen Bishop, 2017 personal communication 
Table 1. Sites likely with Caddo ceramics in the Central Texas region, continued.

\begin{tabular}{|c|c|c|}
\hline Site Number & Site Name & References \\
\hline \multicolumn{3}{|l|}{ Bell County } \\
\hline 41BL22 & Garth & Creel et al. 2013; Shafer et al. 1964; Shafer 2012 \\
\hline 41BL23 & Penny Winkle & $\begin{array}{l}\text { Creel et al. 2013; Perttula et al. 2003; } \\
\text { Shafer et al. } 1964\end{array}$ \\
\hline 41BL58 & Simmons & Shafer et al. 1964 \\
\hline 41BL65 & Domino & Shafer 2006; Shafer et al. 1964 \\
\hline 41BL104 & Evoe Terrace & Sorrow et al. 1967; Creel et al. 2013 \\
\hline 41BL116 & Bowmer & Voltin 1996; Malof 2001; Perttula 2012 \\
\hline 41BL117 & & TARL files \\
\hline 41BL125 & & Kehl 1987, 1990 \\
\hline 41BL323 & Gault & Creel et al. 2013 \\
\hline No trinomial & $5^{\text {th }}$ Street Rd. & Creel et al. 2013 \\
\hline \multicolumn{3}{|l|}{ Bexar County } \\
\hline $41 \mathrm{BX} 17$ & Granburg & Schuetz 1966 \\
\hline 41BX1253 & Stealth Cave & Kibler 2002; Veni et al. 1998 \\
\hline \multicolumn{3}{|c|}{ Blanco County } \\
\hline $41 \mathrm{BC} 73$ & Wolf & $\begin{array}{l}\text { Highley and Lenefield 1977; Chandler 1995; } \\
\text { T. R. Hester, } 2016 \text { personal communication }\end{array}$ \\
\hline $41 \mathrm{BC} 114$ & Wheatley & Creel et al. 2013; Greer 1976 \\
\hline \multicolumn{3}{|l|}{ Bosque } \\
\hline$\overline{41 \mathrm{BQ} 20}$ & Brawley's Cave & Olds 1965 \\
\hline 41BQ46 & Horn Shelter No. 2 & Forrester 1985 \\
\hline 41BQ285 & & $\begin{array}{l}\text { Creel et al. 2013; Griffith et al. 2010; } \\
\text { Perttula et al. } 2010\end{array}$ \\
\hline 41BQ293 & & Jones 2009 \\
\hline 41BQ295 & & Jones 2009 \\
\hline No Trinomial & Ann's Cave & Mayborn Museum Collection \\
\hline \multicolumn{3}{|l|}{ Brown } \\
\hline 41BR307 & & Creel et al. 2013 \\
\hline \multicolumn{3}{|l|}{ Burnet } \\
\hline 41BT1 & Grelle & TARL files \\
\hline \multicolumn{3}{|l|}{ Coke } \\
\hline $41 \mathrm{CK} 66$ & & Creel et al. 2013; Shafer 1969 \\
\hline 41CK120 & Pavo & Creel et al. 2013; Shafer 1969 \\
\hline \multicolumn{3}{|l|}{ Coleman } \\
\hline No Trinomial & Frank Mills Collection & Smith 1936 \\
\hline No Trinomial & Millard Collection & Creel et al. 2013 \\
\hline
\end{tabular}


Table 1. Sites likely with Caddo ceramics in the Central Texas region, continued.

\begin{tabular}{|c|c|c|}
\hline Site Number & Site Name & References \\
\hline \multicolumn{3}{|l|}{ Concho } \\
\hline$\overline{41 C C 131}$ & Currie & Treece et al. 1993 \\
\hline \multicolumn{3}{|l|}{ Coryell } \\
\hline $41 \mathrm{CV} 17$ & Grimes-Houy Shelter & Miller and Jelks 1952; Perttula 2016a \\
\hline $41 \mathrm{CV} 21$ & Grimes-Houy Midden & Miller and Jelks 1952; Perttula 2016a \\
\hline $41 \mathrm{CV} 26$ & Urbankte & $\begin{array}{l}\text { Miller and Jelks 1952; Perttula and Shafer 2016; } \\
\text { Perttula 2016b }\end{array}$ \\
\hline $41 \mathrm{CV} 33$ & Ament Shelter & Miller and Jelks 1952; Perttula 2016a \\
\hline $41 \mathrm{CV} 34$ & Ament Midden & Shafer, 2015 personal communication \\
\hline $41 \mathrm{CV} 41-\mathrm{A}$ & & $\begin{array}{l}\text { Creel et al. 2013; Perttula et al. 2003; Abbott and } \\
\text { Trierweiler 1995; Mehalchick et al. } 2003\end{array}$ \\
\hline $41 \mathrm{CV} 48$ & & $\begin{array}{l}\text { Creel et al. 2013; Perttula et al. 2003; } \\
\text { Trierweiler } 1996\end{array}$ \\
\hline $41 \mathrm{CV} 61$ & Stone Rockshelter & Henry et al. 1980 \\
\hline $41 \mathrm{CV} 62$ & L. E. Robertson Shelter & Henry et al. 1980 \\
\hline Near 41CV92 & & $\begin{array}{l}\text { Perttula et al. 2003; Shafer 2006; Thomas 1978; } \\
\text { Mehalchick et al. } 2003\end{array}$ \\
\hline $41 \mathrm{CV} 344$ & & $\begin{array}{l}\text { Creel et al. 2013; Perttula et al. 2003; } \\
\text { Mehalchick et al. } 2003\end{array}$ \\
\hline $41 \mathrm{CV} 960$ & & Abbott and Trierweiler 1995; Mehalchick et al. 2003 \\
\hline $41 \mathrm{CV} 1038$ & & Mehalchick et al. 2003 \\
\hline No Trinomial & Johnson Hole & Miller and Jelks 1952 \\
\hline No Trinomial & Kinsey Farm Spring & Mayborn Museum Collection \\
\hline No Trinomial & Frank Simmons/McLeod Farm & Mayborn Museum Collection \\
\hline No Trinomial & Gun Cornfield & Mayborn Museum Collection \\
\hline No Trinomial & $\mathrm{C}-34$ & TARL Records (Cecil Calhoun) \\
\hline No. 10 & $39 C 3-7$ & Watt 1953 \\
\hline No. 11 & $39 \mathrm{C} 3-14$ & Watt 1953 \\
\hline No. 12 & 39C3, Peugh Branch & Watt 1953 \\
\hline No trinomial & Chrisner's Ranch & Marcus Whittle, 2017 personal communication \\
\hline \multicolumn{3}{|l|}{ Dimmit } \\
\hline 41DM134 & & Thomas R. Hester, 2017 personal communication \\
\hline \multicolumn{3}{|l|}{ Gillespie } \\
\hline 41GL321 & & Malof and Evans 2016 \\
\hline \multicolumn{3}{|l|}{ Hamilton } \\
\hline$\overline{41 \mathrm{HM} 51}$ & Jayroe & $\begin{array}{l}\text { Broehm and Kibler 2004; Kibler and Broehm 2005; } \\
\text { Kibler } 2012\end{array}$ \\
\hline \multicolumn{3}{|l|}{ Hays } \\
\hline 41HY 14 & & Creel et al. 2013 \\
\hline 41HY202-A & Barton (North) & Creel et al. 2013; Ricklis and Collins 1994 \\
\hline 41HY209-T & Mustang Branch & Creel et al. 2013; Ricklis and Collins 1994 \\
\hline
\end{tabular}


Table 1. Sites likely with Caddo ceramics in the Central Texas region, continued.

\begin{tabular}{|c|c|c|}
\hline Site Number & Site Name & References \\
\hline \multicolumn{3}{|l|}{$\underline{\text { Hill }}$} \\
\hline 41HI1 & Kyle Rockshelter & Creel et al. 2013; Jelks 1962 \\
\hline 41HI8 & Blum Rockshelter & Creel et al. 2013; Jelks 1953 \\
\hline 41HI9 & Stansbury & Stephenson 1970 \\
\hline 41HI17 & Bear Creek Shelter & Lynott 1978 \\
\hline $41 \mathrm{HI} 30$ & Lavender & TARL files \\
\hline 41HI34 & Sour Mash & TARL files \\
\hline 41HI50 & Collins & Creel et al. 2013 \\
\hline 41HI53 & Pictograph Shelter & Stephenson 1970 \\
\hline 41HI54 & Buzzard Shelter or Cave & Long 1961; Stephenson 1970 \\
\hline 41HI55 & Sheep Shelter & Stephenson 1970 \\
\hline 41HI105 & McDonald & Creel et al. 2013; Brown et al. 1987 \\
\hline 41HI109 & & Brown 1987 \\
\hline 41HI111 & & Creel et al. 2013; Brown 1987 \\
\hline 41HI134 & & Skinner 1972; Creel et al. 2013 \\
\hline 41HI154 & & Creel et al. 2013; Brown 1987 \\
\hline $41 \mathrm{HI} 210$ & Indian Springs & Skinner and Gallagher 1974 \\
\hline $41 \mathrm{HI} 237$ & & Skinner 1972 \\
\hline 41HI239 & & Creel et al. 2013 \\
\hline 41HI241 & & Creel et al. 2013 \\
\hline No trinomial & Little Buzzard Shelter or Cave & Long 1961 \\
\hline No trinomial & $40 \mathrm{~A} 5-11 / 15$ & Mayborn Museum Complex \\
\hline No trinomials & $\begin{array}{l}\text { Frank Bryan Collection, Hill } \\
\text { and McLennan Counties }\end{array}$ & TARL collections \\
\hline No. 3 & & Bryan 1936:Map 13 \\
\hline No. 4 & & Bryan 1936:Map 13 \\
\hline \multicolumn{3}{|l|}{ Irion } \\
\hline 41IR28 & & Creel et al. 2013 \\
\hline 41IR38 & & Creel et al. 2013; Creel 1990 \\
\hline 41IR50 & Suggs TD Ranch & Creel et al. 2013 \\
\hline \multicolumn{3}{|l|}{ Kendall } \\
\hline$\overline{41 \mathrm{KE} 66}$ & & Chandler 1995 \\
\hline No trinomial & north of Comfort, Texas & Chandler 1995 \\
\hline \multicolumn{3}{|l|}{$\underline{\text { Kerr }}$} \\
\hline No trinomial & near Hunt, Texas & Chandler 1995 \\
\hline \multicolumn{3}{|l|}{ Lampasas } \\
\hline No trinomial & Salt Creek & Field 1956 \\
\hline
\end{tabular}


Table 1. Sites likely with Caddo ceramics in the Central Texas region, continued.

\begin{tabular}{|c|c|c|}
\hline Site Number & Site Name & References \\
\hline \multicolumn{3}{|l|}{$\underline{\text { Llano }}$} \\
\hline 41LL4 & Fall Creek & Creel et al. 2013; Jackson 1938 \\
\hline 41LL76 & Spencer Collection & Creel et al. 2013; Assad and Potter 1979 \\
\hline 41LL413 & Charlotte Graham Collection & Creel et al. 2013 \\
\hline 41LL415 & & Charles Hixson, 2017 personal communication \\
\hline \multicolumn{3}{|l|}{ Mason } \\
\hline $41 \mathrm{MS} 32$ & Honey Creek & Black et al. 1997; Ellis 1997 \\
\hline \multicolumn{3}{|l|}{ McLennan } \\
\hline$\overline{41 \mathrm{ML} 28}$ & Gas Plant & Creel et al. 2013; Jensen 1967 \\
\hline 41ML35 & Baylor & $\begin{array}{l}\text { Creel et al. 2013; Story and Shafer 1965; } \\
\text { Mehalchick and Kibler } 2008\end{array}$ \\
\hline 41ML38 & Stone & Jelks 1970; Watt 1953; Turner-Pearson 2008 \\
\hline 41ML39 & Clark & Watt 1965, 1978; Perttula 2016b \\
\hline $41 \mathrm{ML} 43$ & Cement Hill & Bryan 1935; Watt 1953 \\
\hline 41ML44 & Chupik & Creel et al. 2013; Watt 1941, 1953; Perttula 2016b \\
\hline 41ML46 & Asa Warner & $\begin{array}{l}\text { Creel et al. 2013; Watt 1953, 1956; Perttula 2016b } \\
\text { Turner 1997; Richmond et al. } 1985\end{array}$ \\
\hline 41ML66 & Cement Hill 2 & Atlee 2004 \\
\hline 41ML119 & Tonk Creek Shelter & Perkins 1956 \\
\hline 41ML162 & McMillan & Mehalchick and Kibler 2008 \\
\hline 41ML185 & & Scott et al. 2002 \\
\hline No Trinomial & Camp 3 & Mayborn Museum Collection \\
\hline No Trinomial & Charles Pierce & Mayborn Museum Collection \\
\hline No Trinomial & Near Cement Plant & Bryan 1937 \\
\hline No Trinomial & Fadul Farm & Mayborn Museum Collection \\
\hline No Trinomial & Flag Lake & Watt 1953 \\
\hline No Trinomial & Gene's Farm & Mayborn Museum Collection \\
\hline No Trinomial & Hughes & Mayborn Museum Collection \\
\hline No Trinomial & Mass Burial & Meroney 1936 \\
\hline No Trinomial & Aynesworth Collection & Mayborn Museum Collection \\
\hline No Trinomial & Warner \#1 & Mayborn Museum Collection \\
\hline No Trinomial & Warner \#11 & Mayborn Museum Collection \\
\hline No Trinomial & Warner \#12 & Mayborn Museum Collection \\
\hline No Trinomial & White Rock Creek & Mayborn Museum Collection \\
\hline No. 9 & $39 \mathrm{~B} 5-23$ & Watt 1953 \\
\hline No. 13 & 39B9-2, Gas Bridge & Watt 1953 \\
\hline No. 21 & 39B5-19, Kellum Place & Watt 1953 \\
\hline
\end{tabular}

\section{Medina}

41ME147 Eagle Bluff

T. R. Hester, 2015 personal communication 
Table 1. Sites likely with Caddo ceramics in the Central Texas region, continued.

\begin{tabular}{|c|c|c|}
\hline Site Number & Site Name & References \\
\hline \multicolumn{3}{|l|}{$\underline{\text { Milam }}$} \\
\hline 41MM341 & J. B. White & Gadus et al. 2006; Perttula 2001; Fields 2017 \\
\hline No trinomial & V. Turner Collection & T. R. Hester (2017 personal communication) \\
\hline \multicolumn{3}{|l|}{$\underline{\text { Mills }}$} \\
\hline $41 \mathrm{MI} 4$ & Trotter & Saylor 1974 \\
\hline \multicolumn{3}{|l|}{$\underline{\text { Nolan }}$} \\
\hline 41NL19 & Roby 4:5 & Creel et al. 2013 \\
\hline \multicolumn{3}{|l|}{ San Saba } \\
\hline $41 S S 2$ & Fall Creek No. 2 & Creel et al. 2013; Jackson 1938 \\
\hline $41 \mathrm{SS} 20$ & Finis Frost & Green and Hester 1973 \\
\hline $41 \mathrm{SS} 28 / 177$ & & $\begin{array}{l}\text { Prikryl et al. 2010; } \\
\text { Buddy Whitley, } 2016 \text { personal communication }\end{array}$ \\
\hline 41SS192 & Baker & Charles Hixson, 2017 personal communication \\
\hline \multicolumn{3}{|l|}{ Sterling } \\
\hline $41 \mathrm{ST} 87$ & Davis Hackberry Spring & $\begin{array}{l}\text { Riemenschneider } 1996 \text {; } \\
\text { Eric Schroeder, } 2017 \text { personal communication }\end{array}$ \\
\hline
\end{tabular}

\section{Taylor}

41TA 123

41TA124

41TA 125

41TA186

\section{Tom Green}

$41 \mathrm{TG} 45$

$41 \mathrm{TG} 48$

$41 \mathrm{TG} 91$

41TG346

$41 \mathrm{TG} 424$

41TG541

\section{Travis}

41TV5

41TV29

$41 \mathrm{TV} 40$

$41 \mathrm{TV} 42$

41TV 104

$41 \mathrm{TV} 142$

41TV441

\section{Uvalde}

41UV2
Abilene 4:13

Steadman \#31

Rush

Ben M. Cox Collection

Nancy Edwards Collection

Collins

Smith Rockshelter

Sneed

Hillcrest Bluff

Toyah Bluff

Kincaid Rockshelter
Creel et al. 2013; Creel 1990

Creel et al. 2013

Creel et al. 2013

Creel et al. 2013

Creel et al. 2013; Creel 1990

Creel et al. 2013; Creel 1990

Creel 1990

Creel et al. 2013; Quigg and Peck 1995

Creel et al. 2013

Creel et al. 2013

Creel et al. 2013

Creel et al. 2013

Creel et al. 2013; Suhm 1955, 1956

Suhm 1956, 1957

Creel et al. 2013

Creel et al. 2013

Karbula 2003; Creel et al. 2013

Creel et al. 2013 
Table 1. Sites likely with Caddo ceramics in the Central Texas region, continued.

\begin{tabular}{lll}
\hline Site Number & Site Name & References \\
\hline Williamson & & \\
\hline 41WM8 & Cedar Park Mound & Creel et al. 2013 \\
41WM24 & Cluck Spring & Shafer 2006 \\
41WM71 & Barker & Creel et al. 2013; Perttula et al. 2003; Sorrow 1970 \\
41WM118 & & Creel et al. 2013 \\
41WM124 & Bryan Fox & Creel et al. 2013; Hays 1982 \\
41WM130 & Hoxie Bridge & Bond 1978 \\
41WM133 & Loeve & Creel et al. 2013 \\
41WM163 & & Hays 1982 \\
41WM230 & Loeve-Fox & Prewitt 1974 \\
41WM258 & Bigon-Kubala & Hays 1982 \\
41 WM267 & & Carey Weber, 2016 personal communication \\
41 WM437 & Rowe Valley & Creel et al. 2013; Prewitt 2012; Rush et al. 2015; \\
41 WM763 & & Richmond et al. 1985 \\
No Trinomial & D. C. Crain & TARL files \\
& & T. R. Hester, 2013 personal communication; D. C. \\
& & Crain, 2016 personal communication \\
\hline
\end{tabular}

In the text that follows, I present data gathered on these likely Caddo ceramic sherds from sites and collections in the aforementioned 34 Central Texas and South Texas counties. The presentation moves from one county to another in alphabetical order. In some cases, the ceramic sherd data are summarized from published CRM reports, or from the instrumental neutron activation analysis summarized in Creel et al. (2013), but in other cases, the ceramic sherd data derives from detailed ceramic sherd analyses I have completed on a number of Central Texas ceramic assemblages from (1) curated collections at the Texas Archeological Research Laboratory (TARL) at the University of Texas at Austin, and (2) the Mayborn Museum Complex at Baylor University, as well as the examination of ceramic sherds held by private individuals. 


\section{County by County Descriptions of Sites in Central Texas with Ancestral Caddo Ceramics}

In this section of the report I describe and/or analyze ceramic sherds or vessels by county from aboriginal sites and collections in Central Texas and immediately surrounding counties that in all likelihood are ancestral Caddo vessels and sherds made by Caddo potters in East Texas communities between ca. A.D. 900 and the late $18^{\text {th }}$ century. The level of detail varies considerably between sites and collections, principally depending upon whether I had access to the site collections to conduct stylistic and technological analyses, or had to rely on information presented in CRM reports on ceramic sherds, or had to rely on photographs of sherds from collections in private hands.

\section{Bandera County}

\section{Rainey (41BN33)}

This multiple component prehistoric site is adjacent to a sinkhole on an upland ridge slope in the Sabinal River basin in Bandera County. A single grog-tempered body sherd from an ancestral Caddo vessel decorated with broad and parallel incised lines (Henderson 2001:265 and Figure 161f) was recovered from Feature 16 outside the sinkhole. The ceramic type of the sherd is undetermined, but a calibrated radiocarbon age range of A.D. 1484-1635 on charcoal from Feature 16 suggests the sherd is likely from a Late Caddo period Maydelle Incised jar sherd (Henderson 2001:260 and Table 37).

\section{Paul Olsen Collection, Unrecorded Site}

The Paul Olsen collection from an unrecorded site in Bandera County (Thomas R. Hester, 2011 personal communication) has a single ancestral Caddo incised-punctated sherd, probably from a Maydelle Incised jar. The rim sherd has vertical and curvilinear incised panels filled with rows of tool punctations. On either side of these panels are sets of at least two vertical incised lines (Figure 3).

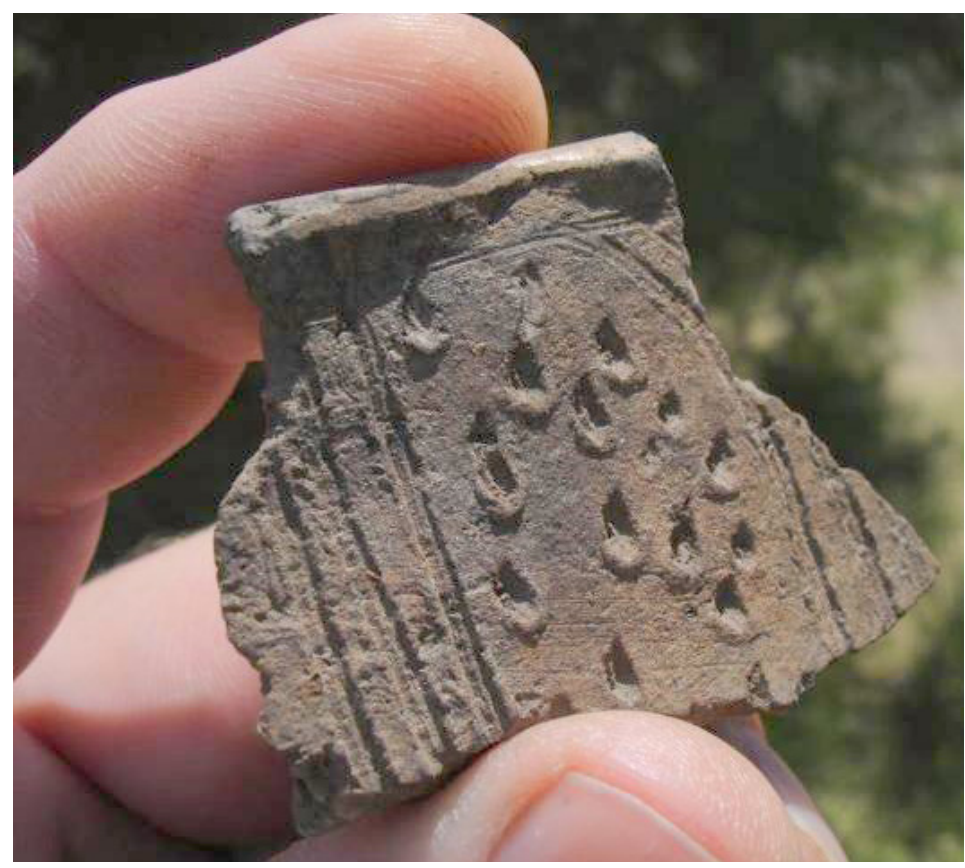

Figure 3. Maydelle Incised sherd from an unreported site in Bandera County, Texas. 


\section{Shirley Nedry Collection, Bandera County, Texas}

Shirley Nedry has collected eight ceramic vessel sherds from the surface of an unrecorded prehistoric site just south of the Albert and Bessie Kronkosky State Natural Area on Red Bluff Creek in the Medina River drainage. With her permission, these sherds have been made available for detailed analysis.

The sherds include seven body sherds and one base sherd, likely from at least three different vessels based on firing conditions and temper identified in each sherd core section (Table 2). Five of the sherds have grog temper (i.e., crushed vessel sherds), two have grog and small pieces of burned bone, and one sherd has grog and bone temper and a sandy paste; this sherd was made from a naturally sandy clay.

Table 2. Shirley Nedry Sherd Collection from Bandera County, Texas

\begin{tabular}{|c|c|c|c|c|c|}
\hline Sherd No. & $\begin{array}{l}\text { Sherd } \\
\text { type }\end{array}$ & $\begin{array}{l}\text { Temper } \\
\text { Conditions }\end{array}$ & $\begin{array}{l}\text { Firing } \\
\text { treatment }\end{array}$ & $\begin{array}{l}\text { Surface } \\
(\mathrm{mm})\end{array}$ & Thickness \\
\hline $1 *$ & body & grog & $\mathrm{G}$ & int. SM & 8.8 \\
\hline 2 & body & $\begin{array}{l}\text { grog-bone- } \\
\text { sandy paste }\end{array}$ & $\mathrm{E}$ & int. SM & 8.1 \\
\hline 3 & base & grog & $\mathrm{E}$ & - & 9.5 \\
\hline 4 & body & grog-bone & $\mathrm{G}$ & ext. SM & 8.4 \\
\hline $5 a$ & body & grog & $\mathrm{B}$ & - & 6.0 \\
\hline $5 b$ & body & grog & $\mathrm{G}$ & $\begin{array}{l}\text { int./ext. } \\
\text { SM }\end{array}$ & 6.7 \\
\hline 6 & body & grog-bone & $\mathrm{G}$ & - & 7.9 \\
\hline 7 & body & grog & $\mathrm{B}$ & $\begin{array}{l}\text { int./ext. } \\
\text { SM }\end{array}$ & 9.1 \\
\hline
\end{tabular}

*this is the only decorated sherd in the collection

$\mathrm{SM}=$ smoothed

The sherds in the collection are from vessels fired in different ways. Two (from a jar and a bowl) were fired and cooled in a low oxygen or reducing environment (B on Table 2), leaving the sherd core and both surfaces a very dark grayish-brown color. Two sherds (a body sherd and base sherd from jars) were incompletely oxidized during firing ( $\mathrm{E}$ on Table 2). The remaining four sherds (three from jars and one from a bowl) are from vessels fired in a reducing environment, but removed from the fire to cool in the open air ( $\mathrm{G}$ on Table 1). These sherds have a dark core and a thin oxidized zone at the exterior surface. Ancestral Caddo vessels in East Texas are typically fired in this manner.

Six of the sherds are likely from thick-walled jars (with body and base thickness greater than $7.9 \mathrm{~mm}$ (see Table 2). The other two sherds are from bowls with vessel wall thicknesses between 6.0-6.7 mm.

One of the sherds in the Shirley Nedry collection is from a decorated vessel (Sherd 1). This body sherd has parallel brushing marks and overlapping opposed incised lines (Figure 4). The decoration on this sherd compares favorably to Spradley Brushed-Incised, a utility ware found on Historic Caddo Allen phase sites (dating from ca. A.D. 1680-1800) in the Neches-Angelina river basins in East Texas. It consists of parallel brushing elements with overlapping straight incised lines that are opposed or perpendicular to the brushing (Marceaux 2011:140 and Figure 5.2; Perttula and Selden 2014:Figure 42). 


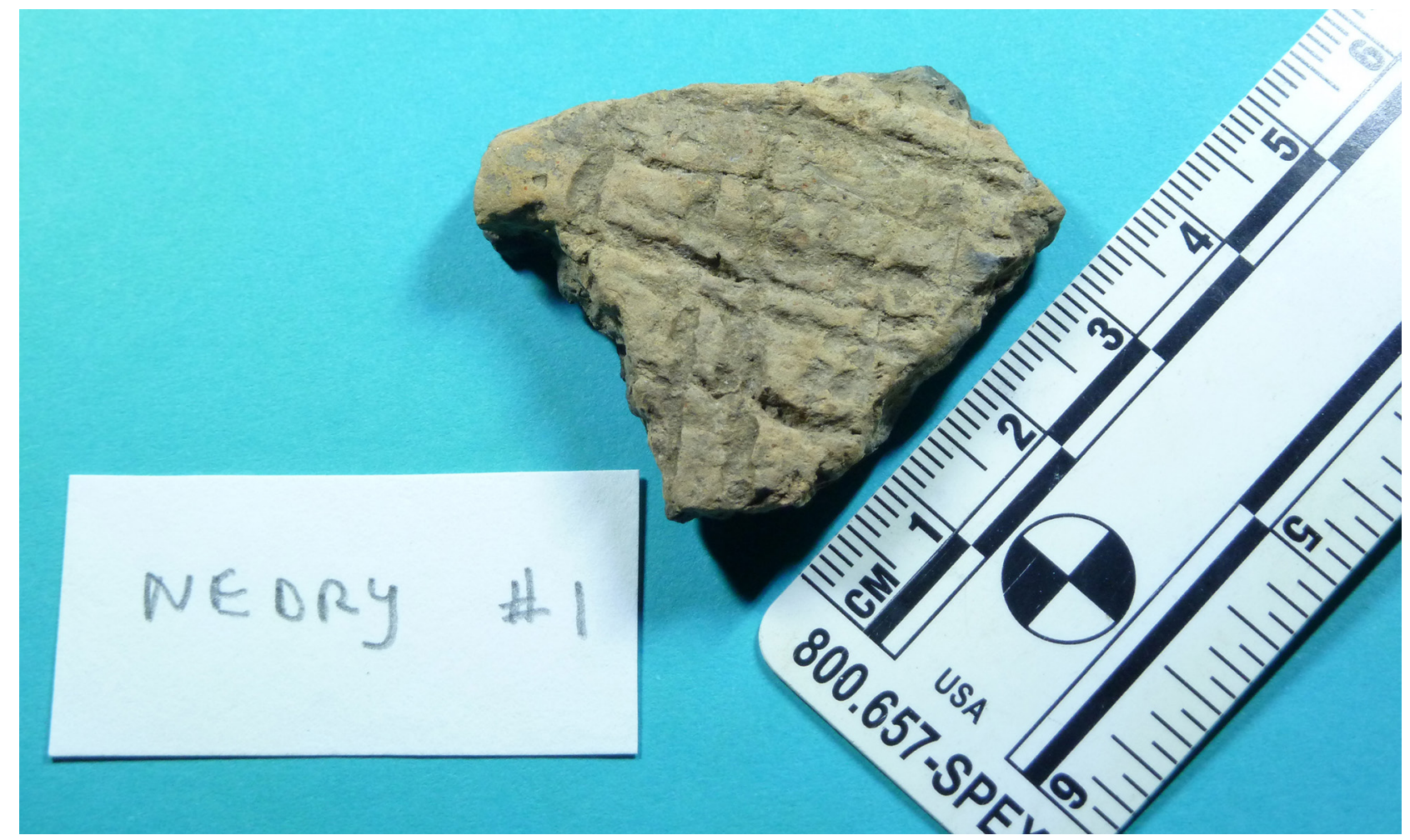

Figure 4. Brushed-incised body sherd from the Shirley Nedry collection, Bandera County, Texas.

The tempers used in vessel manufacture of the sherds in the Nedry collection, as well as the firing conditions, and the one decorated sherd likely from a Spradley Brushed-Incised vessel, indicate that these sherds are from at least three different ancestral Caddo vessels made in East Texas sometime after A.D. 1680. It is most likely that they were made by Caddo potters belonging to a Historic Hasinai Caddo group living in the Neches and Angelina River basins, and through exchange and social networks, the vessels were moved to an aboriginal central Texas group that had settled in what is now Bandera County, Texas.

\section{Bell County}

\section{Garth Site (41BL22)}

Caddo ceramics from the Garth site, on the Leon River, include one grog-tempered sherd with a red slip, a plain grog-tempered body sherd (Shafer et al. 1964), as well as bone-tempered sherds from a jar with a tool punctated rim and a vertical brushed body (Figure 5) (Shafer 2012:Figure 11). Another sherd, tempered with grog and bone, has opposed brushed-incised marks and lines (INAA, UT00384). These sherds suggest use of the site after ca. A.D. 1200, when both red-slipped and brushed vessels were commonly made by certain East Texas Caddo potters. Shafer (2012:48) has noted that "Late Prehistoric sites along the eastern margins of the Leon River and its tributaries had an unusual quantity of ceramics, both locally made and Caddo in origin."

\section{Penny Winkle (41BL23)}

Shafer et al. (1964) recovered 13 sherds from at least four Caddo ceramic vessels at the Penny Winkle site in the Leon River basin at Belton Reservoir. The site has both Austin and Toyah phase diagnostics, but the ceramics appear to be part of the Toyah phase component. 


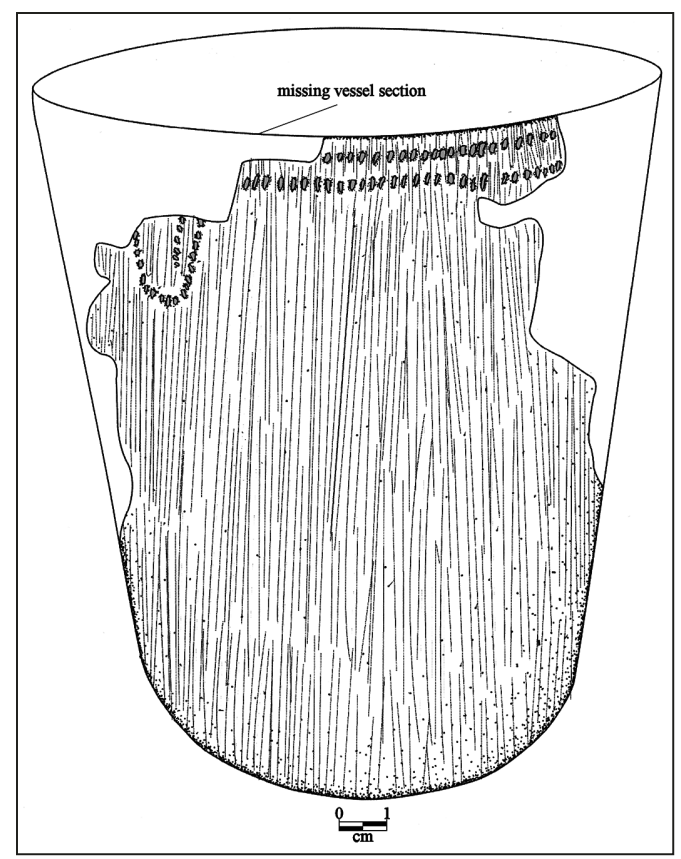

Figure 5. Reconstructed punctatedbrushed jar from the Garth site (41BL22).

The recovered sherds include 10 plain sherds (most are grog-tempered, and are from one vessel) and three grog-tempered sherds from decorated vessels. One carinated bowl sherd has an engraved-brushed design (Shafer et al. 1964:Figure 15g), a jar sherd has brushing marks (Shafer et al. 1964:Figure 15h), and another jar sherd is from a Maydelle Incised vessel with diagonal opposed incised lines (Figure 6); samples of sherds from the Maydelle Incised jar and the parallel brushed body sherd were analyzed for INAA and petrography (Perttula et al. 2003:11). These decorated sherds are consistent with a Late Caddo period Frankston phase ceramic assemblage from the upper Neches River basin in East Texas.

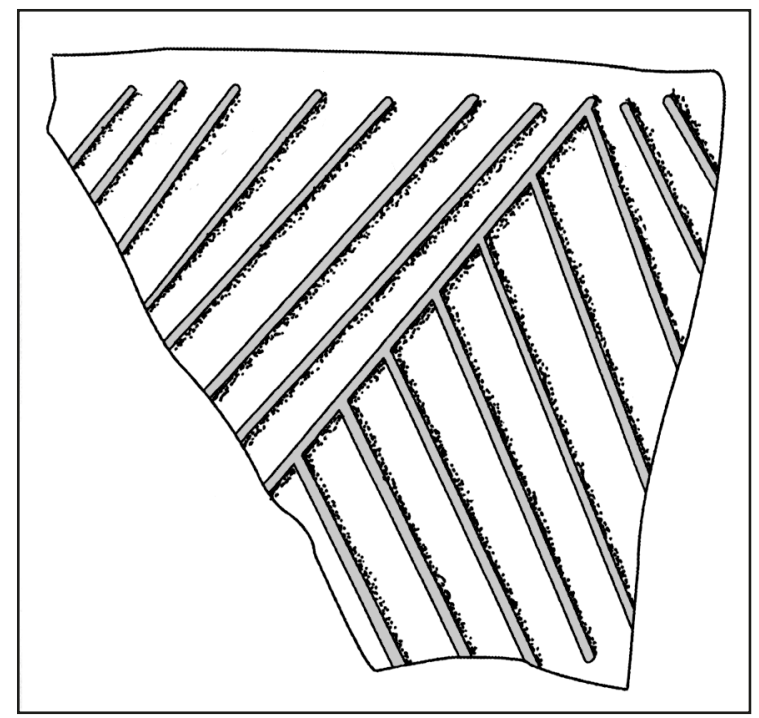

Figure 6. Maydelle Incised jar sherd from the Penny Winkle Site (41BL23). 


\section{Simmons (41BL58)}

The single ancestral Caddo ceramic sherd in the Simmons site assemblage at TARL is a plain grogtempered body sherd.

\section{Domino (41BL65)}

This site has a single grog-tempered rim sherd with horizontal incised lines (Shafer et al. 1964:65-68 and Figure 15j). This sherd is likely from a Davis Incised or Kiam Incised vessel (see Suhm and Jelks 1962:Plates 18 and 45), both types among the assemblage of Early Caddo ceramic wares from the Neches River basin in East Texas, as well as other river basins in the region. The occupation of the site during the Austin phase is consistent with this temporal attribution for the ceramic rim sherd.

\section{Evoe Terrace (41BL104)}

Sorrow et al. (1967:58-59) recovered 16 ceramic vessel sherds from three different parts of the Evoe Terrace site; the site is on an alluvial terrace on the south side of the Lampasas River. Eight of the sherds from Area A are from a single pinched jar, with no obvious temper. The eight sherds recovered in Area B are from two different vessels, neither with any decoration; the temper on one of the vessels was suggested to probably be bone, and the other vessel may not have had a temper, but only a sandy paste (Sorrow et al. 1967:58). Two of the three body sherds in Area D are plain and apparently have only a sandy paste or small particles of bone added as temper (Sorrow et al. 1967:59). The other sherd is described as having a "single, straight, engraved line...or a scratched line" (Sorrow et al. 1967:58), and bone temper.

The ancestral Caddo sherds at this site in the TARL collections include a grog-bone-tempered body sherd with a single straight incised line (perhaps from a Maydelle Incised vessel, INAA UT00024) from Area D, and a grog-tempered body sherd with a straight pinched ridge (INAA, UT00025), from Area A. Both sherds are from Late Caddo period, Frankston phase vessels. Leon Plain sherds are also in the ceramic assemblage, along with numerous Perdiz arrow points and Cliffton arrow point preforms (Sorrow et al. 1967:59).

\section{Bowmer Site (41BL116)}

A total of 56 sherds and 25 sherdlets have been recovered from the Bowmer site during various archaeological investigations (Table 3), beginning with Voltin (1996). All of the sherds from the Bowmer site occur from the surface to a maximum of $99.60 \mathrm{~m}$ elevation, or from the surface to ca. 30 $\mathrm{cm}$ bs. There is a single uni-modal peak in sherd densities by the bottom depth of the levels that contain sherds - $99.75 \mathrm{~m}$ (ca. $15 \mathrm{~cm}$ bs) elevation - but sherds from levels with bottom depths between $99.85 \mathrm{~m}$ (ca. $5 \mathrm{~cm} \mathrm{bs)} \mathrm{and} 99.65 \mathrm{~m}$ (ca. $25 \mathrm{~cm}$ bs) are also relatively abundant. 
Table 3. Provenience of the ceramic sherds from the Bowmer site (41BL116).

\begin{tabular}{|c|c|c|c|c|}
\hline $\begin{array}{l}\text { Provenience } \\
\text { (N and E grid } \\
\text { coordinates) }\end{array}$ & Depth (m bd) & No. of plain sherds & No. of decorated sherds & $\mathrm{N}$ \\
\hline 992-1008 & $99.25-99.20$ & 1 & - & 1 \\
\hline $1001-1002$ & 99.761 & 1 & - & 1 \\
\hline 1001-1006 & Surface-99.75 & 2 & - & 2 \\
\hline $1001-1007$ & $\begin{array}{l}\text { Surface-99.75 } \\
99.70-99.65\end{array}$ & $\begin{array}{l}2 \\
-\end{array}$ & $\begin{array}{l}1 \\
1\end{array}$ & $\begin{array}{l}3 \\
1\end{array}$ \\
\hline $1002-1002$ & $99.913-99.60$ & 1 & 1 & 2 \\
\hline $1002-1006$ & $99.70-99.65$ & 1 & - & 1 \\
\hline $1003-1002$ & $\begin{array}{l}99.85-99.75 \\
99.75-99.70\end{array}$ & $\begin{array}{l}1 \\
1\end{array}$ & - & $\begin{array}{l}1 \\
1\end{array}$ \\
\hline $1003-1003$ & $99.75-99.70$ & - & 1 & 1 \\
\hline 1003-1004 & $\begin{array}{l}99.75-99.70 \\
99.70-99.65\end{array}$ & $\begin{array}{l}2 \\
1\end{array}$ & - & $\begin{array}{l}2 \\
1\end{array}$ \\
\hline 1003-1006 & $99.70-99.65$ & 1 & - & 1 \\
\hline 1004-978 & $\begin{array}{l}99.70-99.65 \\
99.65-99.60\end{array}$ & $\begin{array}{l}1 \\
1\end{array}$ & $\begin{array}{l}2 \\
1\end{array}$ & $\begin{array}{l}3 \\
2\end{array}$ \\
\hline 1004-1001 & $\begin{array}{l}99.90-99.85 \\
99.75-99.70\end{array}$ & $\begin{array}{l}1 \\
1\end{array}$ & - & $\begin{array}{l}1 \\
1\end{array}$ \\
\hline 1004-1003 & $\begin{array}{l}99.80-99.75 \\
99.75-99.70\end{array}$ & $\begin{array}{l}- \\
1\end{array}$ & $\begin{array}{l}1 \\
-\end{array}$ & $\begin{array}{l}1 \\
1\end{array}$ \\
\hline 1004-1005 & $99.80-99.75$ & 1 & - & 1 \\
\hline 1004-1007 & $99.80-99.75$ & 1 & 1 & 2 \\
\hline 1005-1004 & $99.80-99.75$ & 1 & - & 1 \\
\hline $1005-1007$ & Surface-99.75 & 2 & 2 & 4 \\
\hline 1006-1003 & $99.90-99.85$ & 1 & - & 1 \\
\hline 1006-1004 & $\begin{array}{l}99.90-99.85 \\
99.80-99.75\end{array}$ & $\begin{array}{l}4 \\
-\end{array}$ & $\begin{array}{l}- \\
1\end{array}$ & $\begin{array}{l}4 \\
1\end{array}$ \\
\hline
\end{tabular}


Table 3. Provenience of the ceramic sherds from the Bowmer site (41BL116), continued.

\begin{tabular}{|c|c|c|c|c|}
\hline $\begin{array}{l}\text { Provenience } \\
\text { (N and E grid } \\
\text { coordinates) }\end{array}$ & Depth (m bd) & No. of plain sherds & No. of decorated sherds & $\mathrm{N}$ \\
\hline \multirow[t]{2}{*}{$1006-1005$} & $99.95-99.90$ & 2 & - & 2 \\
\hline & $99.90-99.85$ & 1 & 1 & 2 \\
\hline $1006-1006$ & $99.85-99.80$ & 2 & - & 2 \\
\hline \multirow[t]{2}{*}{ 1006-1007 } & $99.85-99.80$ & 1 & - & 1 \\
\hline & $99.75-99.70$ & 1 & - & 1 \\
\hline \multirow[t]{2}{*}{$1023-983$} & $99.85-99.80$ & 1 & 1 & 2 \\
\hline & $99.75-99.70$ & - & 1 & 1 \\
\hline $1025-983$ & $99.85-99.80$ & - & 1 & 1 \\
\hline $1025-984$ & $99.85-99.80$ & - & 2 & 2 \\
\hline Totals & & 38 & 18 & 56 \\
\hline
\end{tabular}

The prehistoric occupation that left the aboriginal sherds was not substantial with respect to the thickness of the archaeological deposits. Units with sherds from more than one $5 \mathrm{~cm}$ level (see Table 3 ) indicate that they come from mean depths of only $5.7-19 \mathrm{~cm}$ bs, suggesting the ceramic-bearing prehistoric occupation was approximately $13 \mathrm{~cm}$ in thickness.

The aboriginal ceramic sherds from the Bowmer site were found in units covering an area of approximately $33 \mathrm{~m}$ (north-south) x $29 \mathrm{~m}$ (east-west), or $957 \mathrm{~m}^{2}$. In the northwestern part of the excavations, the sherd density is 1.0 sherd per $\mathrm{m}^{2}$. This compares to 2.5 sherds per $\mathrm{m}^{2}$ in the western part of the excavations, and only 1.1 sherds per $\mathrm{m}^{2}$ in the main excavation block (Figure 7). Only one sherd was recovered from excavations south of the N1000 grid line. The overall density across the site is only 1.1 sherd per $\mathrm{m}^{2}$, suggesting that there are approximately 1050 sherds from at least an estimated 14 vessels (see below) distributed across this part of the Bowmer site.

The ceramic sherds from the Bowmer site consist exclusively of body sherds from thin-walled vessels tempered, fired, burnished/smoothed, and decorated in several different ways. The detailed analysis of each of the sherds from the Bowmer site is provided in Table 4. 


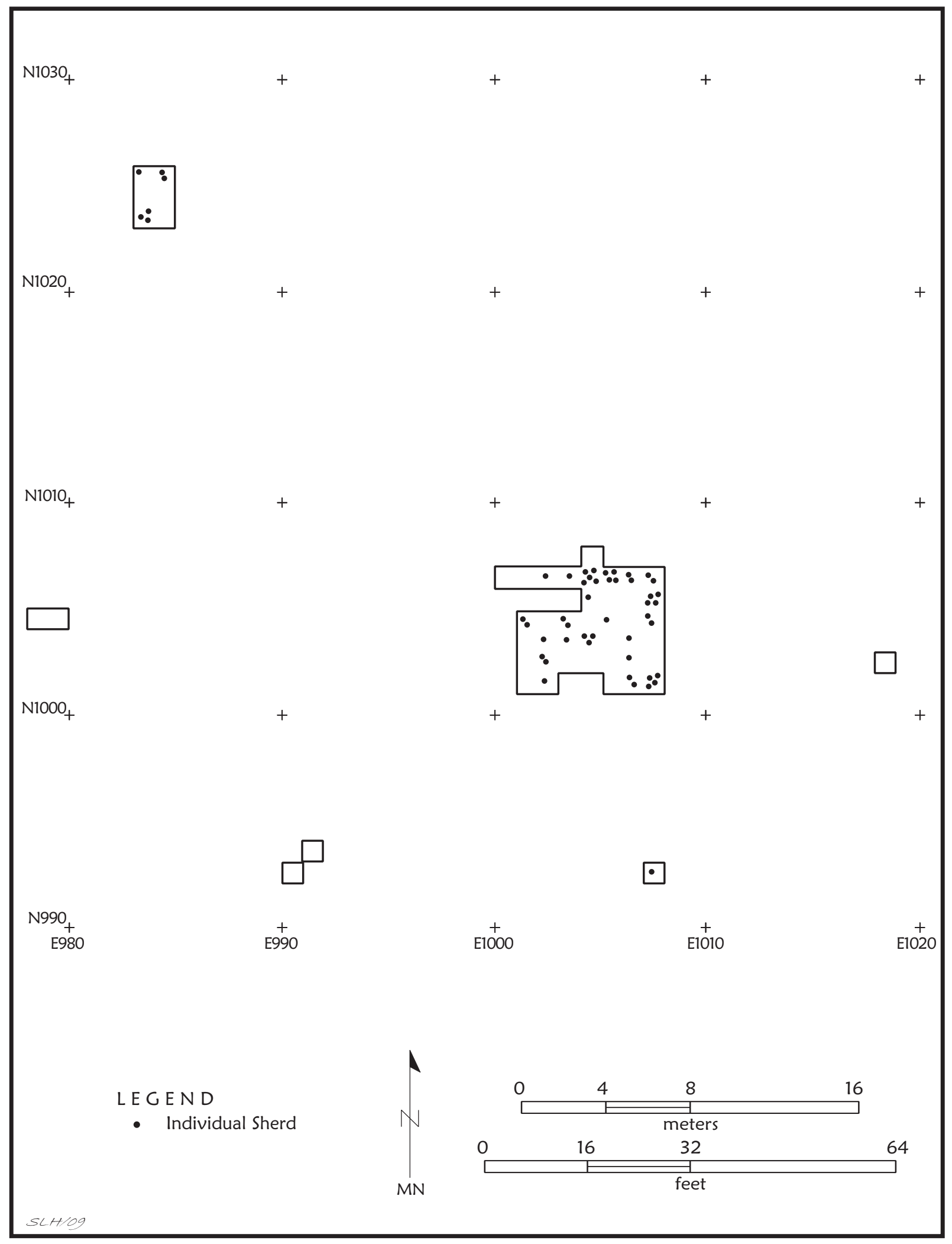

Figure 7. Distribution of ceramic sherds in the excavations at the Bowmer site. 
Table 4. Detailed analysis of the ceramic sherds from the Bowmer site (41BL116).

\begin{tabular}{|c|c|c|c|c|c|c|c|}
\hline $\begin{array}{l}\text { Provenience } \\
\text { ( } \mathrm{N} \text { and } \mathrm{E} \\
\text { grid coordinates) }\end{array}$ & $\begin{array}{l}\text { Depth } \\
\text { (m bd) }\end{array}$ & Sherd Type & $\begin{array}{l}\text { Dec. } \\
(\mathrm{mm})\end{array}$ & Temper & ST & $\mathrm{TH}$ & FC \\
\hline 992-1008 & $99.25-99.20$ & body & plain & $\mathrm{b}$ & - & 5.1 & $\mathrm{~A}$ \\
\hline 1001-1002 & 99.761 & body & plain & $b-h$ & E B & 4.9 & $\mathrm{~A}$ \\
\hline \multirow[t]{2}{*}{ 1001-1006 } & \multirow[t]{2}{*}{ Surf-99.75 } & body & plain & $b-h$ & I B & 5.5 & $\mathrm{~A}$ \\
\hline & & body & plain & $b-h$ & E B & 5.2 & $\mathrm{~A}$ \\
\hline \multirow[t]{4}{*}{$1001-1007$} & \multirow[t]{3}{*}{ Surf-99.75 } & body & Eng. & $\mathrm{h}$ & E B & 5.6 & $\mathrm{~A}$ \\
\hline & & body & plain & $b-h$ & E B & 4.9 & $\mathrm{~A}$ \\
\hline & & body & plain & $b-h$ & E B & 7.6 & $\mathrm{D}$ \\
\hline & $99.70-99.65$ & body & Eng. & $b-h$ & $\mathrm{I} / \mathrm{E} \mathrm{B}$ & 6.0 & $\mathrm{~A}$ \\
\hline \multirow[t]{2}{*}{$1002-1002$} & \multirow[t]{2}{*}{$99.913-99.60$} & body & plain & $b-h$ & I B & 5.7 & $\mathrm{~A}$ \\
\hline & & body & Eng. & b-h & E B & 5.5 & $\mathrm{~A}$ \\
\hline $1002-1006$ & $99.70-99.65$ & body & plain & b-h & $\mathrm{I} / \mathrm{E} \mathrm{B}$ & 5.1 & $\mathrm{~A}$ \\
\hline $1003-1001$ & $99.80-99.75$ & body & plain & $b-g$ & $\mathrm{I} / \mathrm{E} \mathrm{B}$ & 4.5 & $\mathrm{G}$ \\
\hline 1003-1002 & $99.75-99.70$ & body & plain & $\mathrm{b}$ & - & 6.7 & B \\
\hline $1003-1003$ & $99.75-99.70$ & body & Eng. & none & I/E SM & 4.5 & $\mathrm{G}$ \\
\hline \multirow[t]{3}{*}{ 1003-1004 } & \multirow[t]{2}{*}{$99.75-99.70$} & body & plain & $\mathrm{g}$ & E B & 5.6 & A \\
\hline & & body & plain & $\mathrm{b}$ & $\mathrm{I} / \mathrm{E} \mathrm{B}$ & 5.0 & $\mathrm{~A}$ \\
\hline & $99.70-99.65$ & body & plain & b-h & $\mathrm{I} / \mathrm{E} \mathrm{B}$ & 5.3 & $\mathrm{~A}$ \\
\hline 1003-1006 & $99.70-99.65$ & body & plain & $\mathrm{b} / \mathrm{SP}$ & - & 6.9 & K \\
\hline \multirow[t]{4}{*}{ 1004-978 } & \multirow[t]{3}{*}{$99.70-99.65$} & body & B-I & $\mathrm{b}$ & - & 6.4 & $\mathrm{H}$ \\
\hline & & body & B-I & $\mathrm{b}$ & - & 6.6 & $\mathrm{H}$ \\
\hline & & body & plain & $\mathrm{b}$ & - & 6.5 & $\mathrm{H}$ \\
\hline & $99.65-99.60$ & body & $\mathrm{B}$ & $\mathrm{b}$ & I SM & 6.3 & $\mathrm{~B}$ \\
\hline $1004-978$ & $99.65-99.60$ & body & plain & $\mathrm{b}$ & I B & 2.8 & $\mathrm{~F}$ \\
\hline \multirow[t]{2}{*}{ 1004-1001 } & $99.90-99.85$ & body & plain & $b-h$ & E B & 5.6 & $\mathrm{~A}$ \\
\hline & $99.75-99.70$ & body & plain & $\mathrm{b}-\mathrm{h}$ & E B & 5.4 & $\mathrm{~A}$ \\
\hline \multirow[t]{2}{*}{ 1004-1003 } & $99.80-99.75$ & body & $\mathrm{B}$ & $b-h$ & I B & 4.8 & $\mathrm{~A}$ \\
\hline & $99.75-99.70$ & body & plain & $\mathrm{b}-\mathrm{h}$ & - & 5.7 & $\mathrm{C}$ \\
\hline 1004-1005 & $99.80-99.75$ & body & plain & $\mathrm{b}$ & $\mathrm{I} / \mathrm{E} \mathrm{B}$ & 3.9 & $\mathrm{D}$ \\
\hline
\end{tabular}


Table 4. Detailed analysis of the ceramic sherds from the Bowmer site (41BL116), continued.

\begin{tabular}{|c|c|c|c|c|c|c|c|}
\hline $\begin{array}{l}\text { Provenience } \\
\text { ( } \mathrm{N} \text { and } \mathrm{E} \\
\text { grid coordinates) }\end{array}$ & $\begin{array}{l}\text { Depth } \\
\text { (m bd) }\end{array}$ & Sherd Type & $\begin{array}{l}\text { Dec. } \\
(\mathrm{mm})\end{array}$ & Temper & ST & $\mathrm{TH}$ & $\mathrm{FC}$ \\
\hline \multirow[t]{2}{*}{ 1004-1007 } & \multirow[t]{2}{*}{$99.80-99.75$} & body & Eng. & $\mathrm{b}-\mathrm{h}$ & $\mathrm{I} / \mathrm{E} \mathrm{B}$ & 6.2 & $\mathrm{~A}$ \\
\hline & & body & plain & $\mathrm{b}-\mathrm{h}$ & I B & 5.4 & $\mathrm{~A}$ \\
\hline $1005-1004$ & $99.80-99.75$ & body & plain & b-h & $\mathrm{I} / \mathrm{E} \mathrm{B}$ & 5.9 & A \\
\hline \multirow[t]{4}{*}{ 1005-1007 } & \multirow[t]{4}{*}{ Surf-99.75 } & body & plain & b-h & I/E SM & 5.5 & A \\
\hline & & body & Eng. & $\mathrm{b}-\mathrm{h}$ & E B & 5.9 & $\mathrm{~A}$ \\
\hline & & body & Eng. & b-h & $\mathrm{I} / \mathrm{E} \mathrm{B}$ & 5.3 & $\mathrm{C}$ \\
\hline & & body & plain & b-h & - & 5.6 & $\mathrm{~A}$ \\
\hline $1006-1003$ & $99.90-99.85$ & body & plain & $\mathrm{b}$ & $\mathrm{I} / \mathrm{E} \mathrm{B}$ & 5.9 & $\mathrm{H}$ \\
\hline \multirow[t]{5}{*}{ 1006-1004 } & \multirow[t]{4}{*}{$99.90-99.85$} & body & plain & b-h & E B & 5.1 & A \\
\hline & & body & plain & $\mathrm{b}$ & $\mathrm{I} / \mathrm{E} \mathrm{B}$ & 4.2 & $\mathrm{H}$ \\
\hline & & body & plain & $\mathrm{b}-\mathrm{h}$ & E B & 4.9 & $\mathrm{~A}$ \\
\hline & & body & plain & $\mathrm{b}-\mathrm{h}$ & $\mathrm{I} / \mathrm{E} \mathrm{B}$ & 5.2 & $\mathrm{~A}$ \\
\hline & $99.80-99.75$ & body & Eng. & $\mathrm{b}-\mathrm{h}$ & E B & 5.6 & $\mathrm{~A}$ \\
\hline \multirow[t]{4}{*}{ 1006-1005 } & \multirow[t]{2}{*}{$99.95-99.90$} & body & plain & $\mathrm{b}$ & $\mathrm{I} / \mathrm{E} \mathrm{B}$ & 4.1 & $\mathrm{~F}$ \\
\hline & & body & plain & $\mathrm{b}$ & $\mathrm{I} / \mathrm{E} \mathrm{B}$ & 4.0 & $\mathrm{~F}$ \\
\hline & \multirow[t]{2}{*}{$99.0-99.85$} & body & Eng. & $\mathrm{b}-\mathrm{h}$ & $\mathrm{I} / \mathrm{E} \mathrm{B}$ & 5.4 & $\mathrm{~A}$ \\
\hline & & body & plain & $\mathrm{b}-\mathrm{h}$ & $\mathrm{I} / \mathrm{E} \mathrm{B}$ & 6.2 & $\mathrm{~A}$ \\
\hline \multirow[t]{2}{*}{ 1006-1006 } & \multirow[t]{2}{*}{$99.85-99.80$} & body & plain & $\mathrm{b}-\mathrm{h}$ & E B & 5.6 & $\mathrm{~A}$ \\
\hline & & body & plain & b-h & E B & 5.5 & A \\
\hline \multirow[t]{2}{*}{ 1006-1007 } & $99.85-99.80$ & body & plain & b-h & $\begin{array}{l}\text { E B/ } \\
\text { I SM }\end{array}$ & 4.6 & $\mathrm{H}$ \\
\hline & $99.75-99.70$ & body & plain & $\mathrm{h}$ & - & 3.3 & $\mathrm{G}$ \\
\hline \multirow[t]{2}{*}{$1023-983$} & \multirow[t]{2}{*}{$99.85-99.80$} & body & plain & $\mathrm{b}$ & - & 5.1 & $\mathrm{~K}$ \\
\hline & & body & I & $\mathrm{b}$ & I B & 5.4 & $\mathrm{~F}$ \\
\hline $1023-983$ & $99.75-99.70$ & body & tP & $\mathrm{b}$ & - & 5.8 & $\mathrm{~F}$ \\
\hline $1025-983$ & $99.85-99.80$ & body & B-I & $\mathrm{b}$ & - & 5.6 & $\mathrm{~F}$ \\
\hline \multirow[t]{2}{*}{$1025-984$} & \multirow[t]{2}{*}{$99.85-99.80$} & body & B-I & $\mathrm{b}$ & - & 5.5 & $\mathrm{~F}$ \\
\hline & & body & I & $\mathrm{b}$ & I B & 5.4 & $\mathrm{~B}$ \\
\hline
\end{tabular}

Decoration: $\mathrm{tP}=$ tool punctated; Eng.= engraved; $\mathrm{B}=$ brushed; $\mathrm{B}-\mathrm{I}=$ brushed-incised; $\mathrm{I}=$ incised

Temper: $\mathrm{b}=$ bone; $\mathrm{h}=$ hematite; $\mathrm{g}=$ grog or fired clay; $\mathrm{o}=$ organics; $\mathrm{SP}=$ sandy paste

$\mathrm{ST}=$ surface treatment: $\mathrm{I}=$ interior; $\mathrm{E}=$ exterior; $\mathrm{SM}=$ smoothed; $\mathrm{B}=$ burnished/floated

FC=firing condition (see Teltser 1993; Perttula 2005): A, oxidizing; B, reducing; C-E, incompletely oxidized; F-H, reducing, but cooled in a high oxidizing environment; $\mathrm{I}-\mathrm{L}=$ =incompletely oxidized, possibly smudged; $\mathrm{X}=$ multiple oxidized and reduced bands in the sherd core section

TH=thickness 
Approximately half of the sherds from the Bowmer site excavations are from a single vessel (either a bowl or a carinated bowl) found in the main block (referred to hereafter as Vessel 1). This vessel, represented by 29 body sherds, is bone and hematite-tempered, has a relatively simple engraved decoration (see below), is well burnished on both interior and exterior vessel surfaces, and was fired and cooled in a high oxygen environment (cf. Teltser 1993:Figure 2a). The other sherds - based on temper, decoration, wall thickness, and firing conditions - are from as many as 13 other vessels, either plain $(n=7)$ or decorated $(n=6)$; none of these vessels are represented by more than six sherds, indicating a high degree of fragmentation/breakage and vessel dispersion across the Bowmer site.

Based on the breakage patterns of the sherds, the pottery from the Bowmer site was made using clay coils. Although there are no rim or base sherds in the sherd assemblage, it is likely that vessel construction began with the base and then proceeded by stacking the coils one upon another, progressing up the vessel body to the rim. These coils were welded together by "pressing each rope [or clay coil] down on the vessel's interior surface while pressing and pulling up on the pot's exterior" (Johnson 1994:205).

The prevalence of burned and crushed bone temper in the sherds from the Bowmer site (Table 5) clearly demonstrates that these sherds are almost exclusively from bone-tempered wares, regardless of the other aplastics that were documented in the sherd pastes. Similar bone-tempered ceramic assemblages, some of which have sherds from engraved vessels, are documented over a large part of Central and southern Texas in both prehistoric and early historic archaeological contexts, and the plain wares are commonly referred to (although not necessarily with good reason) as Leon Plain when such sherds are found in Late Prehistoric (post-ca. A.D. 1200) contexts and Goliad ware when found in early to late historic $18^{\text {th }}$ century mission contexts (Hester 1989; Ricklis 1995, 1999, 2000). In fact, "despite the difference in names, no clear-cut technological distinctions have been successfully recognized; hence Leon Plain and Goliad ware probably represents a continuation of the same pottery tradition" (Walter 2007:87). Approximately 96 percent of the sherds from the Bowmer site have bone temper (Table 5).

Table 5. Temper use in the Bowmer site sherds.

\begin{tabular}{|c|c|c|c|c|}
\hline Temper & Vessel 1 & Other engraved wares & Utility ware & Plain sherds \\
\hline bone & - & - & $88.9 *$ & 62.5 \\
\hline bone-hematite & 100.0 & 50.0 & 11.1 & 18.8 \\
\hline bone/sandy paste & - & - & - & 6.3 \\
\hline bone-grog & - & - & - & 6.3 \\
\hline hematite & - & - & - & 6.3 \\
\hline none & - & 50.0 & - & - \\
\hline \multicolumn{5}{|l|}{$\begin{array}{l}\text { summary temper } \\
\text { analysis }\end{array}$} \\
\hline sherds with bone & 100.0 & 50.0 & 100.0 & 93.7 \\
\hline sherds with hematite & 100.0 & 50.0 & 11.1 & 25.1 \\
\hline sherds with grog & - & - & - & 6.3 \\
\hline
\end{tabular}

$*=$ percentage 
Tempers were added to the paste to hold the constituents of vessels together, but not limit the natural plasticity of the clays chosen for vessel manufacture; too much temper added to the paste, and the clay would be too limp to manipulate and shape, but too little temper, and a vessel would be likely to spall and break when it was being fired. Although not quantified here, the amount of bone added to the paste ranged from less than 5 percent to between 5-25 percent of the clay paste. Crushed and burned bone was likely added to a vessel's paste by these aboriginal potters because crushed and burned bone produces with little effort angular particle shapes whose coarseness gave vessels tempered with it the ability to withstand thermal shock. Johnson (1994:205) also has suggested that the addition of bone temper-as well as the absolute amount of the distinctive temper added to the paste - was "to counteract the tackiness of the highly plastic, fine-grained clay that they preferred... if not enough bone is added to such clay, the greenware will ruinously crack and spit." That the bone temper in the Bowmer site ceramic sherds was fine to mediumtextured suggests that the clay used for vessel manufacture was not particularly fine-grained or highly plastic as that documented by Johnson (1994) from various Toyah phase sites in Central Texas.

Hematite, which is a fairly common occurrence on the site (Andy Malof, April 2009 personal communication) may have been added to the paste of certain vessels strictly as a matter of personal choice by individual potters, but it may have served a useful purpose nonetheless. That is, the occurrence of crushed grains of hematite in the paste would have enhanced a vessel's ability to melt and fuse the paste constituents during firing, thus resulting in a dense, hard body, and a reduced vessel porosity (Rice 1987:96). Similarly, the addition of a coarse temper like hematite pieces would have aided a vessel's ability to withstand thermal shock. Vessels with crushed pieces of hematite are particularly prevalent in the engraved Vessel 1 (see Table 4).

One plain sherd has small pieces of fired clay or grog temper (see Table 5) along with fine or moderate amounts of bone temper. Whether these pieces represent deliberately added crushed sherd fragments - as is so commonly seen in East Texas Caddo ceramic wares - or incidental inclusions incorporated in the clay paste during its preparation for vessel manufacture has not been determined. Perhaps the potters of this bone-grog-tempered vessel recognized that the addition of grog or fired clay to the vessel paste slowed the oxidation process during firing, creating darker-colored vessels in a reducing firing environment (or lighter tan, orange, and brown colors in oxidizing environments), while allowing them to be fired longer, and producing a harder ceramic vessel (Rice 1987:354; Teltser 1993:532, 540). Since grog has expansion coefficients generally comparable to the coefficients of the clay paste most commonly seen in aboriginal pottery vessels, this would have contributed further to the ability of fired vessels to withstand heat-related stresses, as well as increasing their flexural strength (Rice 1987:362).

Only one (1.8 percent) of the Bowmer bone-tempered sherds has a sandy paste (see Table 5), and the remainder have a silty to clayey paste. The occurrence of a single sandy paste vessel sherd suggests that only rarely did the aboriginal potters there make use of a naturally sandy clay for vessel manufacture (i.e., the clay contains some natural tempering particles in the form of sand).

Technological and petrographic studies of Late Prehistoric ceramics from Central and South Texas sites indicate that bone-tempered sandy paste pottery is relatively common in $13^{\text {th }}$ to $17^{\text {th }}$ century sites. Depending upon their location in these regions, if sandy paste bone-tempered pottery was manufactured, it accounts for as little as 22-50 percent of the sherds or vessel groups (Hester and Parker 1970; Black 1986a, 1986b; Ricklis and Collins 1994; Quigg and Peck 1995; Perttula 2009) to as much as 70-100 percent (Black 1986b; Rogers and Perttula 2005). The most reasonable explanation for the technological diversity documented in Central and South Texas bone-tempered pottery is that it is both (1) a reflection of situational (physical and geological) variations in the character of the clay sources that were available for vessel manufacture, and (2) the knowledge that aboriginal potters had about clay as well as ceramic 
pastes and fabrics (the quantity and proportion of aplastics and other inclusions, both natural and additive) that could be brought to bear to insure the successful manufacture of plain bone-tempered pottery vessels that had different intended functions. It is important to document both the natural variation that must exist in the clay sources in the region (e.g., Neff and Glascock 2005:C-12 to C-13) that would have been suitable for ceramic manufacture, as well as the intra-regional variation in pottery fabrics (i.e., the mixture of clay and temper to make pottery) that is suspected to have characterized the ceramic assemblages produced by a diverse number of aboriginal groups at different times and in different places across this large region.

The 18 decorated sherds in the Bowmer site sherd assemblage are equally divided between fine wares $(n=9)$ and utility wares $(n=9)$. The fine wares include the engraved vessel sherds from bowls and/or carinated bowls, while the utility wares are the coarse paste decorated vessels, usually cooking or storage jars and simple bowls. These wares, when found on Caddo sites in East Texas, are known to have been made and used differently, based on functional, technological, and stylistic analyses on numerous Caddo sherd assemblages in the broader East Texas region, with uses ranging from food service, cooking of food stuffs, as containers for liquids, and for plant food/seed crop storage. How do the decorated sherds from the Bowmer site compare to Caddo decorated vessel sherds?

The Vessel 1 decorated sherds $(n=7)$ include several different finely engraved elements (Figure 8ad) that are found on the rim and /or upper body of a bowl or carinated bowl; there are no rim sherds or sherds broken at the carination to definitively establish its form. Based on the combination of engraved elements, the engraved motif consists of a single horizontal engraved line at the base of an engraved panel on the rim and upper body, and the panel is composed of a series of at least four diagonal opposed engraved lines (Figure 8a-b). Comparable decorative elements and motifs are found in Caddo fine wares from Early Caddo (ca. A.D. 900-1200) and Middle Caddo period (ca. A.D. 1200-1400) contexts in East Texas, although because of the generalized motif, the specific defined ceramic type is not known. The Vessel 1 engraved sherds are confined to the main block excavation at the Bowmer site (Figure 9).

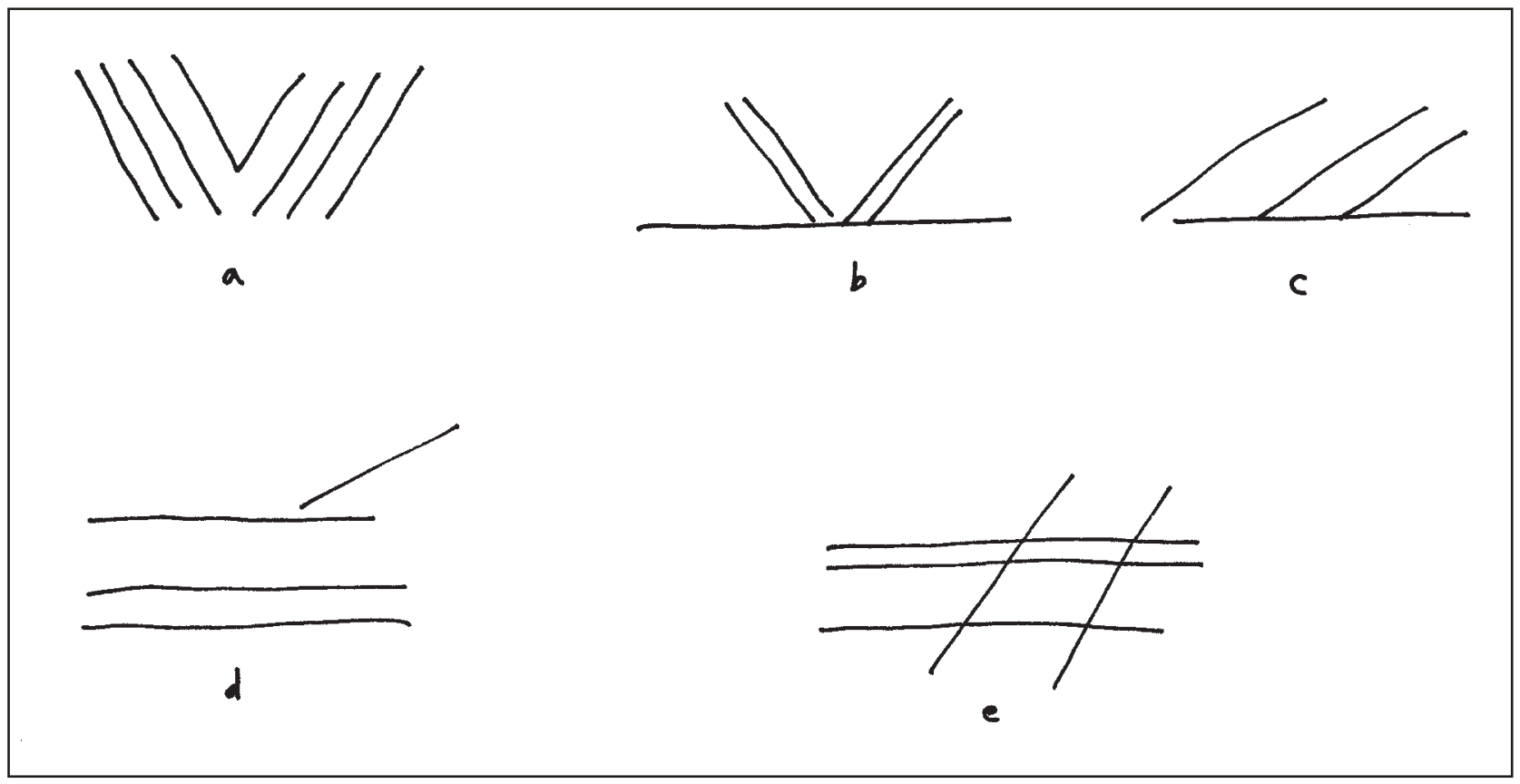

Figure 8. Decorative elements represented among the engraved sherds at the Bowmer site: a-d, Vessel 1; e, another engraved vessel. Provenience: a, N1005 E1007, Surface to 99.75 m; b, N1004 E1007, 99.8099.75 m; c, N1001 E1007, 99.70-99.65 m; d, N1006 E1005, 99.90-99.85 m; e, N1005 E1007, Surface to $99.75 \mathrm{~m}$. 


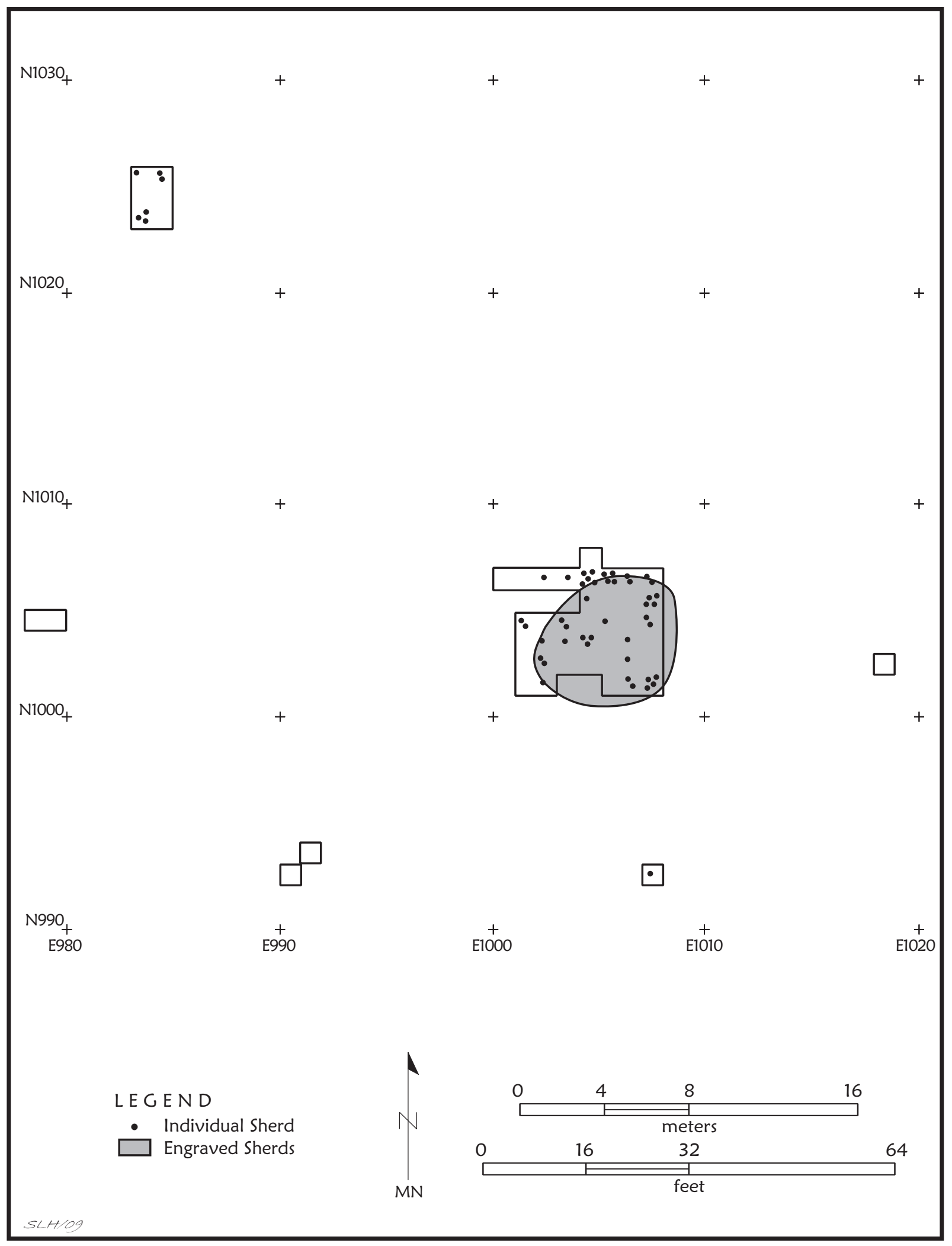

Figure 9. Distribution of engraved sherds at the Bowmer site. 
The two other engraved sherds are from two different vessels. One of the sherds has a set of parallel engraved lines, while the other has both parallel engraved lines and broadly-spaced cross-hatched lines (see Figure 8e). If it were not for differences in temper, firing conditions, or body wall thickness, the design and execution of the finely engraved sherds could comfortably also be attributed to Vessel 1. It seems likely that the Vessel 1 and other engraved sherds are part of a ceramic assemblage left during a single occupational episode dating before ca. A.D. 1400.

The utility wares include body sherds from an estimated four (or possibly five) bone-tempered vessels with punctated $(n=1)$, incised $(n=2)$, brushed $(n=2)$, and brushed-incised $(n=4)$ decorative elements. The one punctated sherd has a single row of tool punctates. The incised body sherds include one with a single straight incised line and another with widely-spaced sets of parallel lines. The temporal or typological affiliation of these sherds is not known.

The brushed and brushed-incised sherds have a northern and western distribution in the Bowmer site excavations (Figure 10), different from that documented for the fine wares. Two of the sherds have parallel (probably oriented vertically on the vessel body) brushing marks, while three of the brushedincised sherds have sets of parallel and closely-spaced brushed and incised lines, likely also oriented vertically on the body of utility ware jars. The last brushed-incised sherd has parallel brushing marks on the exterior vessel surface and a single straight incised line on the vessel interior surface.

Sherds from brushed, brushed-incised, and brushed-punctated vessels have been found in prehistoric and early historic aboriginal sites in both Central Texas and East Texas Caddo sites (Suhm 1955; Ricklis and Collins 1994:Table 47; Perttula et al. 2003; Shafer 2006). In both regions, brushed pottery appears to be present only in post-A.D. 1200/1300 sites, although it is not usually particularly abundant in Central Texas sites, since ceramic vessel sherds of any kind are generally sparse in this region. Brushed pottery in the Big Cypress, middle Sabine, and Neches-Angelina river basins in East Texas comprises at least 40-60 percent of all the decorated sherds in many large ceramic assemblages; brushed pottery becomes especially common after the $15^{\text {th }}$ century A.D. in this part of the Caddo area, reaching proportions of more than 80 percent in some early historic Caddo sites (Perttula 2013; Perttula et al. 2003:11). Much of the brushed pottery in East Texas Caddo sites is bone-tempered, as is the case with brushed Central Texas pottery.

Many of the pottery sherds from the three Bowmer site have been either smoothed or burnished on one or both vessel surfaces: burnishing of interior and exterior sherd surfaces is particularly common in the assemblage, more so on the Vessel 1 and plain sherds (Table 6). Sherds with burnished and/or floated (i.e., a rubbing of the vessel surface that "brings to the surface many fine-grained particles," Johnson 1994:193) exterior surfaces comprise between 50-79.3 percent of the sherds; 33-50 percent of the sherds also have burnishing on interior vessel surfaces. Smoothed vessel surfaces are not common among any of the wares. 


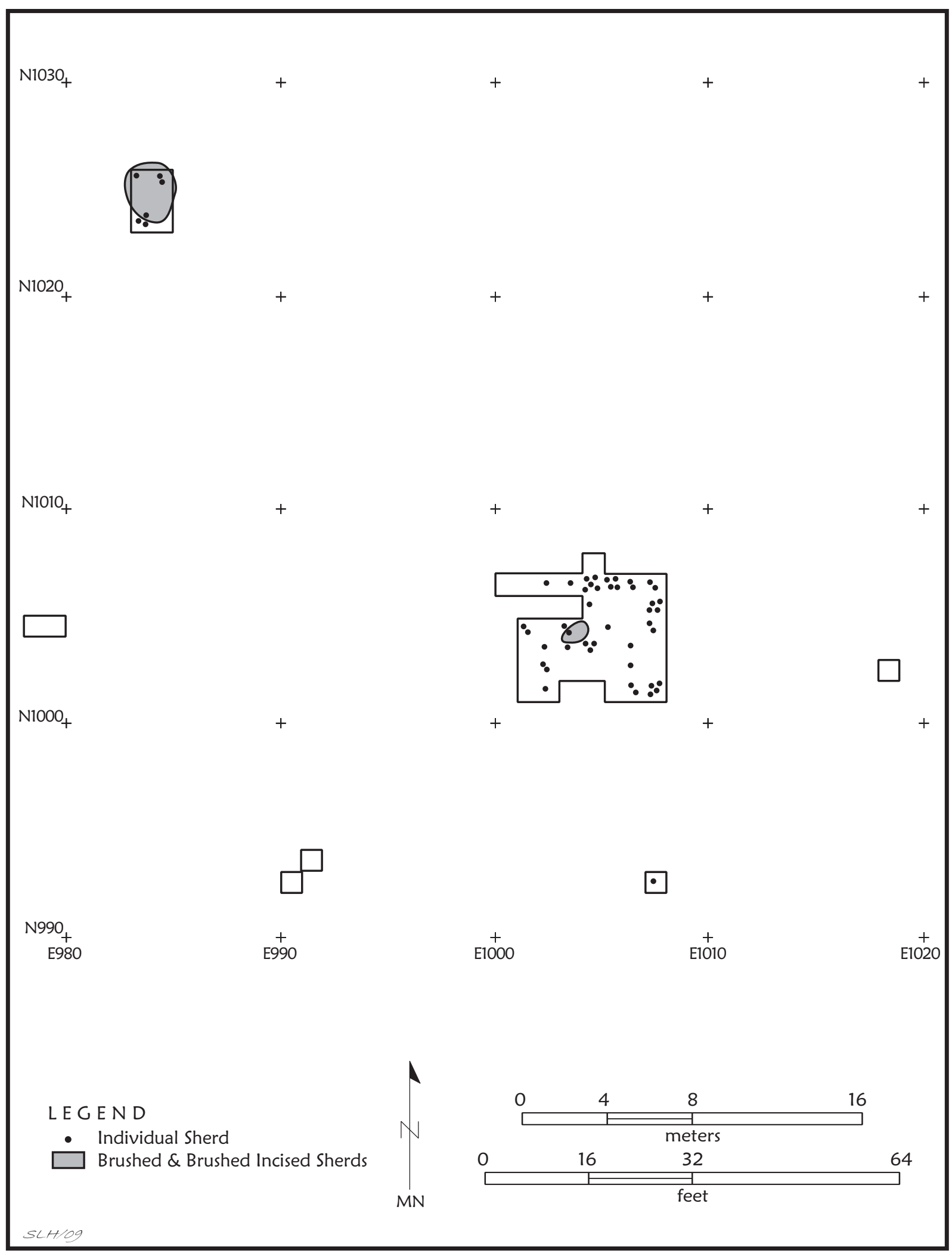

Figure 10. Distribution of brushed and brushed-incised sherds at the Bowmer site (41BL116). 
Table 6. Surface treatment on the sherds from the Bowmer site (41BL116).

\begin{tabular}{lllll}
\hline Surface Treatment & Vessel 1 & Other engraved & Utility ware & Plain sherds \\
\hline int. smoothed & $3.4^{*}$ & 50.0 & 11.1 & 6.3 \\
ext. smoothed & 3.4 & 50.0 & - & - \\
int. burnished & 41.4 & 50.0 & 33.3 & 50.0 \\
ext. burnished & 79.3 & 50.0 & - & 50.0 \\
\hline
\end{tabular}

$*=$ percentage

When done, the burnishing or smoothing of the pottery from the Bowmer site was likely completed primarily to lower the permeability of particular vessels (cf. Rice 1996:148), to better hold liquids or food stuffs (cf. Johnson 1994:193) in plain or engraved bowls or carinated bowls, or to increase their heating effectiveness (in the case of utility ware cooking jars) Smoothing also served to better weld the vessel coils together before firing.

Given that burnishing is more prevalent on sherd exterior surfaces in the sherd assemblage from the site (see Table 6) - but is still commonly seen on interior vessel surfaces - suggests that many of the sherds are from vessels that were not used for cooking per se, but probably instead to serve and hold foods and liquids. The practice of smoothing or burnishing interior surfaces of such vessels would have been advantageous in the repeated use of such serving vessels. Additionally, the exterior smoothing and burnishing was probably also designed for stylistic and display purposes, creating a flat and lustrous surface (cf. Johnson 1994:193), even if that surface was not decorated.

The pottery from the Bowmer site was fired in a variety of ways. The engraved Vessel 1 sherds were fired and cooled in a high oxygen environment (Table 7). The potters that made this engraved vessel were successful in firing it at a sufficiently high temperature and duration that the paste was completely oxidized, producing a durable vessel that was not subject to diminished strength from cumulative thermal fatigue, cracks, or fractures.

Table 7. Firing conditions of the sherds from the Bowmer site (41BL116).

\begin{tabular}{lllll}
\hline Firing Condition & V.1 & Other engraved & Utility ware & Plain sherds \\
\hline Oxidizing & $100.0^{*}$ & - & 11.1 & - \\
Incompletely oxidized & - & 50.0 & - & 18.3 \\
Reducing & - & - & 22.2 & 6.3 \\
$\begin{array}{l}\text { Reducing, cooled in } \\
\text { the open air }\end{array}$ & - & 50.0 & 66.7 & 62.5 \\
$\begin{array}{l}\text { Smothered, sooted, } \\
\quad-\end{array}$ & - & - & 12.5 \\
\hline
\end{tabular}

$*$ percentage

The other engraved sherds were from vessels either incompletely oxidized during firing, or fired in a low oxygen or reducing environment (probably smothered in a bed of coals from a wood fire). Between 68.8-88.9 percent of the utility ware and plain ware sherds were also fired in a reducing environment (see Table 7). Many of these sherds were from vessels that were subsequently cooled in a high oxygen 
environment (i.e., fire-hardened vessels were removed from the fire to cool), where either one or both vessel surfaces had thin oxidized or light-colored (reddish-brown to yellowish-brown) surface colors. The more heterogeneous firing conditions in the remainder of the vessel sherd assemblage suggests that as long as the porosity of the vessels being used at the Bowmer site was not excessive, and there was a good balance between clay plasticity and temper constituents, they were not fired for as long a time as the harder engraved wares, but they were still quite serviceable vessels.

Two plain sherds from the Bowmer site have a distinctive core, much of the core having a light oxidized exterior and a thin dark interior cross-section (see Table 7), suggesting they are from vessels that have been smothered, sooted, or smudged during firing. Aten and Bollich (2002:54-55) note that this manner of vessel firing is characteristic of a sandy paste pottery ware such as Goose Creek Plain, var. unspecified. They also suggest that vessels with this kind of firing may have been placed in a fire with the "orifice [of the vessel] facing into the fire." Furthermore, the sherds with cores lighter than the surfaces may have come from vessels where "after extended firing that burned off all organics, the fire may have been smothered to cause reduction and darkening of the exterior surface."

Regardless of the ware, the vessel sherds from the Bowmer site have thin body walls (Table 8). Mean body wall thickness ranges only from 4.95-5.76 $\mathrm{mm}$.

Table 8. Mean thickness of the body wall of the Bowmer site (41BL116) sherds.

\begin{tabular}{llll}
\hline Ware & Mean thickness $(\mathrm{mm})$ & Standard deviation $(\mathrm{mm})$ & Coefficient of variation \\
\hline Vessel 1 & 5.46 & 0.28 & 5.1 \\
Other engraved & 4.90 & 0.40 & 8.2 \\
Utility ware & 5.76 & 0.46 & 8.0 \\
Plain sherds & 4.95 & 1.16 & 23.4 \\
\hline
\end{tabular}

The quite uniform thickness of vessel body sherds between the different wares at the Bowmer site-especially the engraved and utility wares with CV values ranging only from 5.1-8.2 (see Table 8) - suggest that the aboriginal potters were adept at the manufacture and finishing of vessels with a narrowly defined idea regarding the acceptable thickness of usable vessels. The plain sherds are much more variable in thickness, likely because there are several different vessels represented (estimated seven vessels) in the plain sherds, and some of these may have been of different sizes, or are from functionallyspecific classes of pottery that have thicker walls than other kinds of vessels in use (cf. Ulrich 2006:125).

In summary, the ceramic vessel sherds from the Bowmer site include 29 from Vessel 1, an engraved bone-tempered bowl or carinated bowl, two other engraved sherds from separate vessels, nine utility ware brushed, brushed-incised, incised, and punctated sherds from an estimated four vessels, most likely jars, and 16 plain sherds from an estimated seven vessels. These sherds are from uniformly thin-walled (4.9-5.76 $\mathrm{mm})$, smoothed to burnished, and bone- or bone-hematite-tempered vessels made from a silty or clayey paste that were either fired in a high oxygen or oxidizing environment (Vessel 1) or in a low oxygen or reducing environment (utility wares and plain sherds), then left to cool in the open air. In these technological characteristics, the bone- and bone-hematite-tempered vessel sherds from the Bowmer site are very similar to $13^{\text {th }}$ to $17^{\text {th }}$ century A.D. aboriginal sherd assemblages from a number of Central and South Texas Toyah phase sites (see Perttula 2009:Table 11), and would suggest that these sherds are from vessels made by groups that ranged across both regions. However, the diversity of decorated sherds from the Bowmer site, particularly the engraved sherds from a minimum of three vessels, may tell a different story with respect to the origins and cultural affiliation of these vessel sherds. 
While not found in great numbers, engraved sherds from vessels of apparent Caddo origin have been found at a number of sites in Central Texas (see Watt 1953; Jelks 1962; Sorrow et al. 1967; Stephenson 1970; Ricklis and Collins 1994; Turner 1997; Perttula et al. 2003; Shafer 2006), particularly sites "restricted to the eastern margin of the Edwards Plateau and the prairie environment immediately to the east and northeast of the plateau" (Ricklis and Collins 1994:305 and Figure 155). These engraved wares are from contexts that in East Texas Caddo sites would date from Early Caddo (ca. A.D. 900-1200) to Historic Caddo (ca. A.D. 1680-1800) times, but with an apparent peak in Caddo style engraved pottery in Central Texas prairie sites dating before ca. A.D. 1300 (cf. Shafer 2006). The Bowmer site engraved wares, although from an undated context, may also be from an occupation that falls in this early period. However, the recovery of brushed pottery from Bowmer-if this pottery is associated with the engraved wares, which seems likely given its depth in the archaeological deposits and the small occupation area with ceramic sherds - suggests (if temporal comparisons with the East Texas Caddo area are appropriate with respect to brushed utility wares, since some brushed pottery may have been made in Central Texas and were not Caddo trade wares, see Suhm 1955:19) that the occupation would have been after ca. A.D. 1200/1250, and perhaps even after ca. A.D. 1300.

Shafer (2006:5) has strongly suggested that "[a]rguable prehistoric Caddoan [sic] groups occupied the central Brazos valley and its tributaries by A.D. 1100 if not earlier, based on cross-dating artifact styles from the George C. Davis site... Terminal dates are ca. A.D. 1250-1300, based on cross-dating and extant dates" from prehistoric sites in Central Texas. Shafer considers these groups the Prairie Caddo. He goes on to hypothesize that the southern Prairie Caddo (i.e., the central Brazos and its tributaries) permanently occupied "portions of the central Brazos valley with intermittent and interdigitated Caddo presence in the peripheries to the west and south" (Shafer 2006:7). The Bowmer site is located in one of these proposed peripheral areas to the west of the Brazos River.

It has been further suggested by Shafer (2006:10) that Caddo ceramics made at the George C. Davis site in the middle Neches River valley were moving or being exported to outlying settlements in the southern Prairie Caddo area. This pottery was thought to have been obtained during feasting activities at the George C. Davis site, and then apparently carried back to Central Texas and used "essentially for domestic roles" (Shafer 2006:26). He also suggests that "the absence of fine engraved pottery would be expected in small hunting camps," while larger villages on the Brazos and various tributaries would have a "variety of vessels in both form and decoration" (Shafer 2006:10). It is not known if the Bowmer site is considered a hunting camp, but Malof (2009 personal communication) suggests it is a base camp used seasonally, probably during the late summer/early fall; the occupational area is small. Nevertheless, this site, located in a peripheral part of the central Brazos river basin, contains an impressive diversity among its small sample of sherds of engraved wares (none specifically identified as coming from Early Caddo types), decorated utility wares, and sherds from plain vessels. All of it is bone-tempered, which is prima facie evidence that these sherds did not come from the George C. Davis site, as almost all the pottery from this site is grog-tempered (Shafer 2006:25).

Another possibility, one I favor, is that Caddo vessels manufactured in a number of different regions in East Texas (see Perttula et al. 2003:Figure 16) were only very occasionally traded or exchanged for various reasons (not just feasting) with aboriginal hunter-gatherer groups whose territorial range included the Central Brazos river basin. These same hunter-gatherer groups did make their own pottery, primarily a plain bone-tempered ware as well as probably a brushed-punctated utility ware (Boothe Brushed) that closely resembles Bullard Brushed in character. On the basis of a stylistic, petrographic, and chemical analysis of sherds from 11 Central Texas sites (Perttula et al. 2003:Figure 1), Perttula et al. (2003:63) concluded that: 
The generally low number of Caddoan [sic] pottery sherds found on many central Texas sites, and the fact that the pottery was not made from central Texas clays, indicates that the sherds are from vessels traded to local central Texas hunter-gatherers, not vessels produced by Caddoan [sic] peoples who had settled in or were periodically using the central Texas region.

From these findings, the majority of the vessel sherds from the Bowmer site-almost certainly the engraved vessel sherds - are likely to be from vessels made by Caddo potters living in East Texas. Where within this Caddo region is not known presently because the stylistic character of the engraved sherds is not regionally distinctive. The fact that the engraved sherds are from bone-tempered vessels does not help narrow down the region of vessel production because bone-tempered Caddo pottery-whether from plain or decorated vessels - is present in a number of different areas across East Texas (Figure 11). Probably the best known area of bone-tempered Caddo pottery in East Texas, also associated with the manufacture of brushed pottery and distinctive hatched and curvilinear zoned engraved wares, is in the Angelina-lower Sabine river basins, especially after ca. A.D. 1250 (Perttula 2008:Figure 12-3, 2015a:Figure 11). Perhaps some of the Bowmer vessels originated in this part of Hasinai Caddo territory?

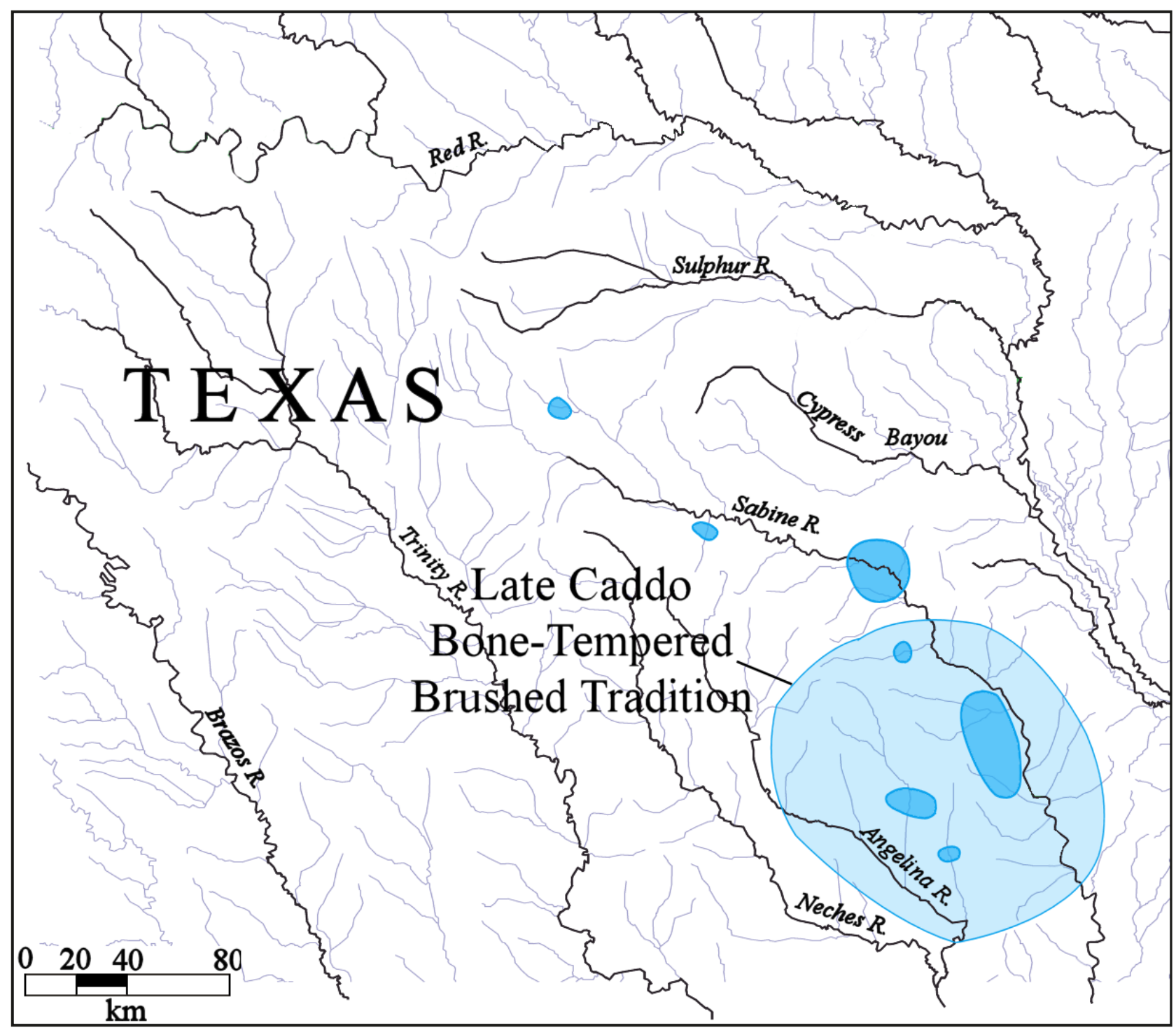

Figure 11. Clusters of Caddo sites with high proportions (>than 40 percent) of bone-tempered sherds in East Texas ceramic assemblages. 


\section{$41 B L 117$}

There are both Toyah phase Leon Plain ceramic sherds and ancestral Caddo ceramic sherds in the TARL collections from 41BL117. The latter include three plain grog-tempered body sherds, a grog-bonetempered body sherd with a row of fingernail punctations, and a grog-bone-tempered body sherd with closely-spaced parallel incised lines.

\section{$41 B L 125$}

This aboriginal site is on Pepper Creek near its confluence with the Leon River (Kehl 1987, 1990). A surface collection obtained in the mid-1960s had 25 ceramic sherds from ancestral Caddo vessels, including a jar and a carinated bowl. These sherds were decorated with brushed, engraved, incised, and punctated decorative elements (Kehl 1990:8), and five of the engraved sherds had a red clay pigment rubbed in the engraved lines. According to Kehl (1990:8), "about half of the sherds contain grog particles as part of the clay paste." The brushed sherds found at 41BL125 are indicative of use by an aboriginal community after ca. A.D. 1200-1250.

\section{$41 B L 323$}

There is a single ancestral Caddo ceramic vessel sherd at 41BL323 in the TARL collections. It is a plain grog-tempered body sherd that can only be roughly dated to only post-ca. A.D. 800 or thereabouts.

\section{$5^{\text {th }}$ Street Road}

There is a grog-bone-tempered Bullard Brushed body sherd (INAA, UT00382) from this site in the TARL collections. The sherd has both parallel and overlapping brushing marks, and is likely from a Bullard Brushed vessel.

\section{Bexar County}

\section{Granburg Site (41BX17)}

Schuetz (1966:56 and Plate 3g) reports that an incised Caddo sherd was recovered in the archaeological investigations at the Granburg site on Salado Creek in the Blackland Prairie in Bexar County. The sherd is from a Maydelle Incised jar with diagonal opposed incised triangle elements (cf. Suhm and Jelks 1962:Plate 52b).

\section{Stealth Cave (41BX1253)}

A cave in a low bluff along Salado Creek at Fort Bullis contains archaeological deposits, including a Maydelle Incised rim sherd (Veni et al. 1998:70-71 and Figure 10; Kibler 2002) with diagonal opposed incised lines (Figure 12). This indicates some use of the cave after ca. A.D. 1400, as Maydelle Incised is a common utility ware in Late Caddo period communities in both Frankston and Titus phase sites in East Texas. 


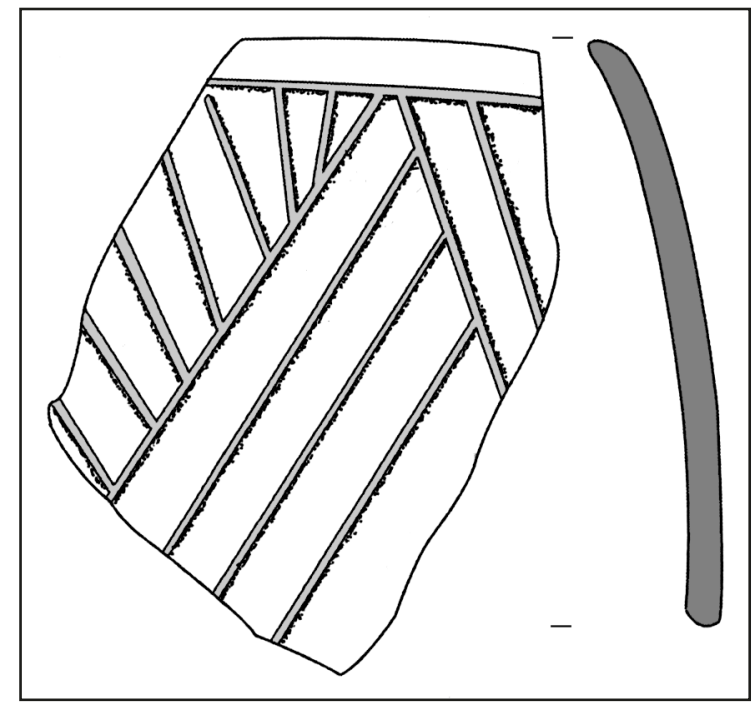

Figure 12. Decorative elements on Maydelle Incised rim sherd from Stealth Cave (41BX1253).

\section{Blanco County}

\section{$41 B C 73$}

This site is a rock shelter near the Pedernales River. Thomas R. Hester (2016 personal communication). An ancestral Caddo Maydelle Incised jar has been found in the site's archaeological deposits (Figure 13). The rim has incised triangle elements filled either with rows of tool punctations or diagonal incised lines pitched in alternating directions around the rim.

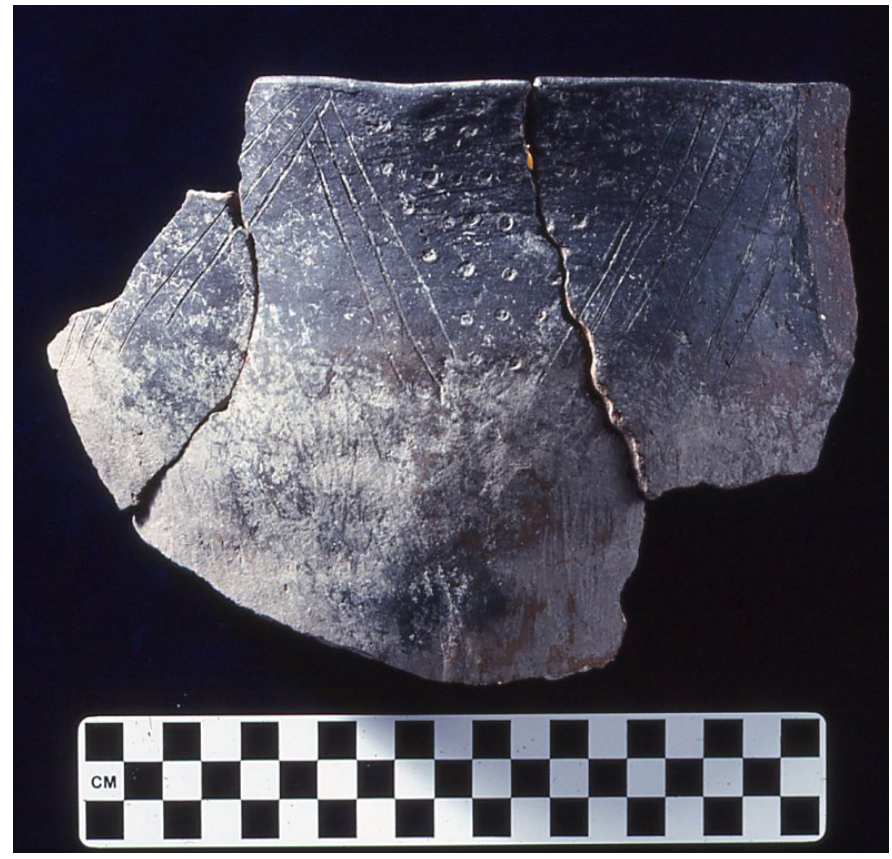

Figure 13. Maydelle Incised rim sherd from 41BC73. Image courtesy of Thomas R. Hester. 


\section{Wheatley (41BC114)}

A single ancestral Caddo sherd was found at the Wheatley site (41BC114) in Pedernales Falls State Park, on an alluvial terrace of the Pedernales River, during 2001 investigations by the Texas Parks and Wildlife Department. The sherd, in the TARL collections, is from a grog-tempered and sandy paste vessel with parallel brushing marks, likely a Bullard Brushed jar sherd.

Earlier, Greer (1976:106 and Table 2) noted that 15 sherds of brushed ceramic sherds, possibly tempered with grog, were recovered at the Wheatley site from two different activity areas $(\mathrm{G}$ and $\mathrm{H})$. Additionally, more than 1200 other sherds from several plain ware vessels were found at the Wheatley site, and these were either bone- or possibly shell-tempered. Greer (1976:140) suggests the site was occupied between ca. A.D. 1150-1300. Because the occurrence of brushed pottery in ancestral Caddo sites in East Texas generally dates after ca. A.D. 1200/1250, and the brushed pottery at the Wheatley site likely originated in the Neches River basin among Middle Caddo (ca. A.D. 1200-1400) and later Frankston phase Caddo peoples of the Late Caddo period, the estimated age of the occupation may be later than Greer (1976) posited.

\section{Bosque County}

\section{Brawley's Cave (41BQ20)}

At least one brushed bone-tempered Caddo ceramic jar sherd has been found in this rock shelter west of the Bosque River. According to Olds (1965:141), the sherd has bone temper, and "a little sand mixed in the paste." This body sherd has parallel brushing marks (Olds 1965:Figure 10i).

\section{Horn Shelter \#2 (41BQ46)}

A small number of ceramic sherds were found in the north end excavations at Horn Shelter \#2; they are in the Mayborn Museum Complex at Baylor University. This includes one bone-tempered Doss Redware body sherd, three plain grog-tempered body and base sherds from a Caddo vessel, and groups of two cross-hatched incised vessels: Vessel 1 ( $n=1$ body sherd) and Vessel 2 ( $n=8$ body sherds) (Figure 14). Both of these vessel sections are from Maydelle Incised jars, suggesting they originated in either the Neches, Sabine, or Big Cypress stream basins in East Texas after ca. A.D. 1300-1400. The one available uncorrected radiocarbon date from the ceramic-bearing deposits in the shelter is A.D. $1340 \pm 135$ (Tx1723) (Watt 1978:119; Forrester 1985:27; Young 1988:Table 1).

\section{$41 B Q 285$}

Site 41BQ285 is located on an alluvial terrace of the North Bosque River on the Grand Prairie. Test excavations were done there in 2006 (Griffith et al. 2010). The five sherds from 41BQ285 that have been studied are from Unit 5, a unit that had an area of burned rock and mussel shell. One sherd (\#51) is from 30-40 cm bs, a second sherd (\#52) is from 40-50 cm bs, and the other three sherds (\#53-1, \#53-2, and \#53-3) are from 50-60 cm bs. Presumably these sherds are from a single prehistoric archaeological component, one apparently associated with the Late Prehistoric Toyah phase (ca. A.D. 1200-1700) (Douglas Boyd, May 2009 personal communication). Based on differences in temper or apparent temper, firing, and decoration (Table 9), the five sherds are apparently from four different vessels; sherds \#53-1 and \#53-3 may be from the same vessel. 


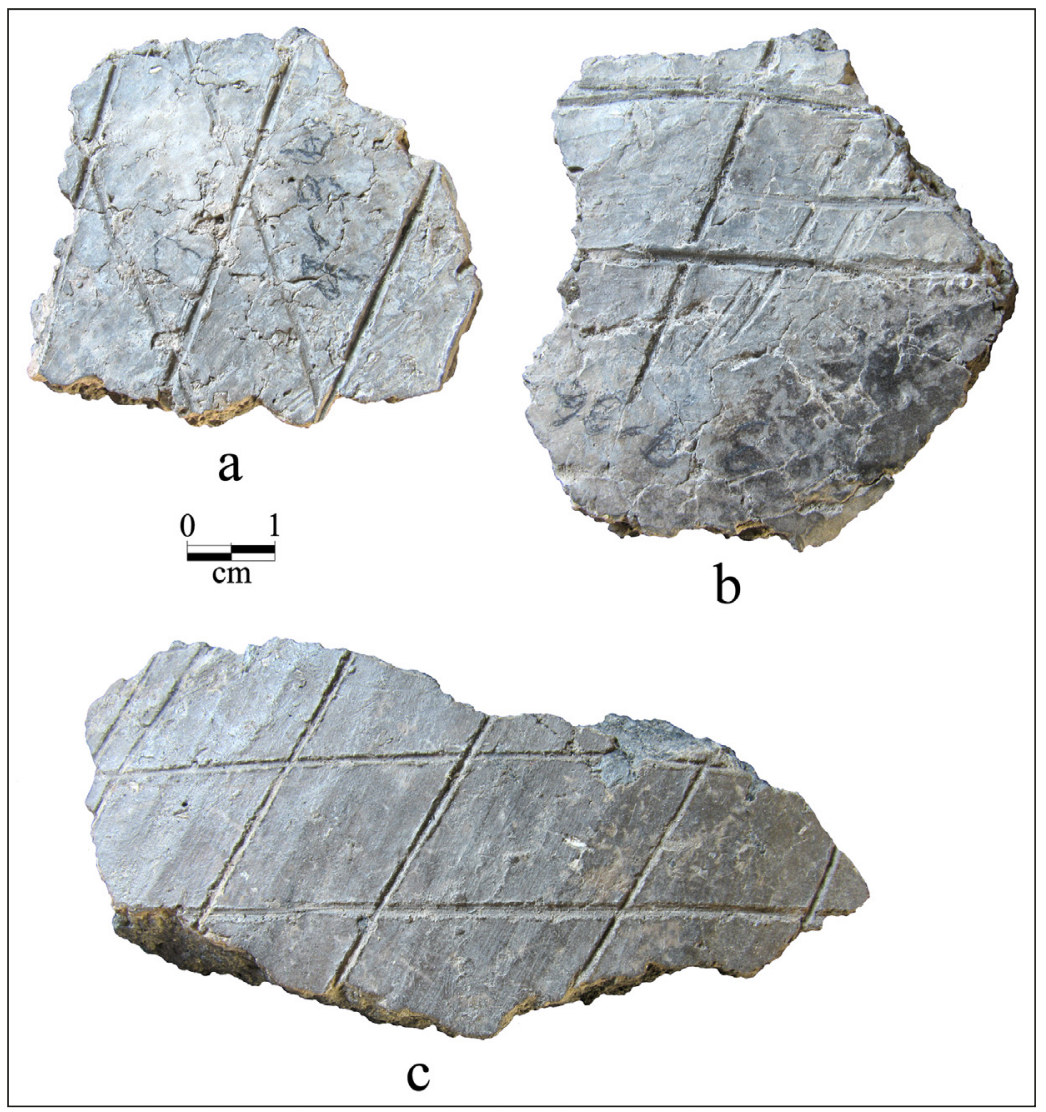

Figure 14. Cross-hatched incised sherds from Horn Shelter \#2 (41BQ46).

Table 9. Aboriginal ceramic sherds from 41BQ285.

\begin{tabular}{|c|c|c|c|c|c|c|}
\hline Sherd No. & $\begin{array}{l}\text { Sherd } \\
\text { type }\end{array}$ & $\begin{array}{l}\text { Surface } \\
\text { Treatment }\end{array}$ & $\begin{array}{l}\text { Visible } \\
\text { Temper }\end{array}$ & $\begin{array}{l}\text { Firing } \\
\text { Conditions }\end{array}$ & $\begin{array}{l}\text { Thickness } \\
(\mathrm{mm})\end{array}$ & Decoration \\
\hline$\# 51$ & $\begin{array}{l}\text { body, } \\
\text { CB }\end{array}$ & $\mathrm{I} / \mathrm{E} \mathrm{B}$ & grog & $\mathrm{F}^{*}$ & $5.8-7.1$ & $\begin{array}{l}\text { diagonal } \\
\text { engraved }\end{array}$ \\
\hline$\# 52$ & body & E B & grog? & $\mathrm{K}$ & 8.2 & plain \\
\hline \#53-1 & body & E B & grog? & $\mathrm{G}$ & 7.7 & plain \\
\hline \#53-2 & body & I SM & $\begin{array}{l}\text { sparse } \\
\text { bone; } \\
\text { sandy } \\
\text { paste }\end{array}$ & K & 7.8 & $\begin{array}{l}\text { single fingernai } \\
\text { punctated }\end{array}$ \\
\hline \#53-3 & body & $\mathrm{I} / \mathrm{E} \mathrm{SM}$ & grog? & G & 7.4 & $\begin{array}{l}\text { single fingernai } \\
\text { punctated }\end{array}$ \\
\hline
\end{tabular}

$\mathrm{CB}=$ carinated bowl; $\mathrm{I}=$ interior vessel surface; $\mathrm{E}=$ =xterior vessel surface; $\mathrm{B}=$ burnished; $\mathrm{SM}=$ smoothed Firing conditions: $\mathrm{F}-\mathrm{G}=$ fired in a reducing environment and cooled in the open air; $\mathrm{K}=$ smothered, sooted, or smudged (see Teltser 1993:Figure 2; Perttula 2005:Figure 5-30) 
Sherd \#51 is from an engraved carinated bowl (see Table 9), a vessel form associated with the manufacture of prehistoric and early historic Caddo ceramics throughout all of East Texas (see Suhm and Jelks 1962). The form of the vessels from which the other four sherds derive is not known-primarily because of the small size of the sherds - but the sherd thickness $(7.4-8.2 \mathrm{~mm})$ and the decoration (fingernail punctated) suggest that they are from utility ware vessels, probably cooking jars; the two exterior burnished sherds \#52 and \#53-1 may be from simple bowls.

Technological, stylistic, petrographic, and instrumental neutron activation analysis (INAA) have all been employed to characterize the nature of the prehistoric ceramic sherds from 41BQ285, but also to ascertain (within reasonable limits) the source and production locales of the five sherds from the Toyah phase occupation at the site (see Perttula et al. 2010). The findings of these various approaches are not completely consistent with each other, and this synthesis of the findings reviews the interpretive possibilities arising from the detailed analysis of the 41BQ285 sherds.

The findings of the petrographic analysis and the INAA of four of the sherds (sherds \#52, \#53-1, \#53-2, and \#53-3) from 41BQ285 are in agreement that they are from sherds manufactured from Central Texas clays (Paste Group 2 and CT 2 chemical group), perhaps alluvial clays available in the immediate vicinity of the site. The stylistic and technological analyses of these four sherds are more ambiguous, primarily because of the fact that two of the sherds are undecorated, and two have simple fingernail punctated designs; there may be incidental fired clay pieces in the pastes (see Table 9). These sherds appear to be from cooking jars, a common vessel form among most prehistoric ceramic traditions in Texas, and otherwise they possess no particular technological or stylistic characteristics that would suggest an East Texas Caddo origin. Thus, it seems reasonable to conclude on the basis of all the analyses that four of the sherds from 41BQ285 represent sherds from a local prehistoric Central Texas ceramic tradition.

Sherd \#51 from 41BQ285 is from a grog-tempered carinated bowl decorated with diagonal engraved lines. On stylistic and technological grounds, as well as based on the vessel form, a form apparently specific to Caddo ceramic traditions in Texas, this particular sherd may reasonably be concluded to be from a Caddo vessel made in East Texas. The petrographic analysis also concludes that this sherd, of Paste Group 1, is from a Caddo vessel made in East Texas. The evidence to support this petrographic analysis conclusion is the use of grog temper added to the paste, the amount of hematite in the paste, as well as the density (pore space) of the paste in comparison to the Paste Group 2 sherds. The INAA, however, of sherd \#51, makes the alternative case that this sherd belongs to the CT 2 chemical group (in fact, the probability of membership of sherd \#51 in the CT 2 chemical group is higher than the other four sherds from 41BQ285, see Perttula et al. 2010:Table 4). Furthermore, no conclusive linkages could be made from the INAA results of sherd \#51 with existing East Texas Caddo chemical groups. What is the most reasonable conclusion, then, concerning the cultural affiliation and production locale of the one engraved and grog-tempered sherd from 41BQ285? The engraved sherd from 41BQ285 appears to be associated with an occupation that would date no earlier than the late $13^{\text {th }}$ century A.D., and might well date after the $15^{\text {th }}$ century A.D.

While Caddo vessels manufactured in a number of different regions in East Texas (see Perttula et al. 2003:Figure 16) may have only been occasionally traded or exchanged for various reasons with aboriginal hunter-gatherer groups whose territorial range included the Central Brazos river basin, these same hunter-gatherer groups did make their own pottery, albeit in low amounts, as indicated by the recovery of locally produced plain and fingernail punctated sherds at 41BQ285 from Paste Group 2, as well as bone-tempered plain and bone-tempered brushed-punctated utility wares (Boothe Brushed) from a number of sites across the region. 
Engraved vessel sherds from Central Texas aboriginal sites, including the one sherd from 41BQ285, are likely to be from vessels made by Caddo potters living in East Texas. Where within this Caddo region the vessel represented by the one engraved sherd at 41BQ285 was made is not known because the stylistic character of the engraved sherd is not regionally distinctive. The fact that the engraved sherd is from a grog-tempered vessel also does not help narrow down the region of vessel production because such Caddo pottery - whether from plain or decorated vessels - is present throughout East Texas in Caddo times.

41BQ285 is located in one of the proposed peripheral areas identified by Shafer (2006) to the west of the Brazos River, and may be considered by some to be a southern Prairie Caddo site. It is not known if 41BQ285 is considered a hunting camp, but Griffith et al. (2010) suggests the site was used for only a limited number of activities and that a wide range of local faunas were exploited by its occupants. These occupants used, broke, and discarded at least one engraved vessel at the site, but during a time period after the George C. Davis site was abandoned (ca. early A.D. 1300s), in the $13^{\text {th }}$ through $16^{\text {th }}$ centuries A.D. (Griffith et al. 2010:Table 3.3). Neither the petrographic analysis or the INAA results suggest, however, that the 41BQ285 vessel was made in the middle Neches River valley, leaving little possibility that its production locale was the George C. Davis Caddo community. This does not mean, however, that a southern Prairie Caddo potter living in the central Brazos River basin did not make the engraved vessel that was subsequently discarded at 41BQ285.

A fourth and final possibility is that the engraved sherd from 41BQ285 was from a vessel made from Central Texas clays, either by Central Texas hunter-gatherers, southern Prairie Caddo, or by an East Texas Caddo group on a foray in the Bosque River basin. The INAA results support the notion that the engraved carinated bowl was made from Central Texas clays (Figure 15), as do certain aspects of

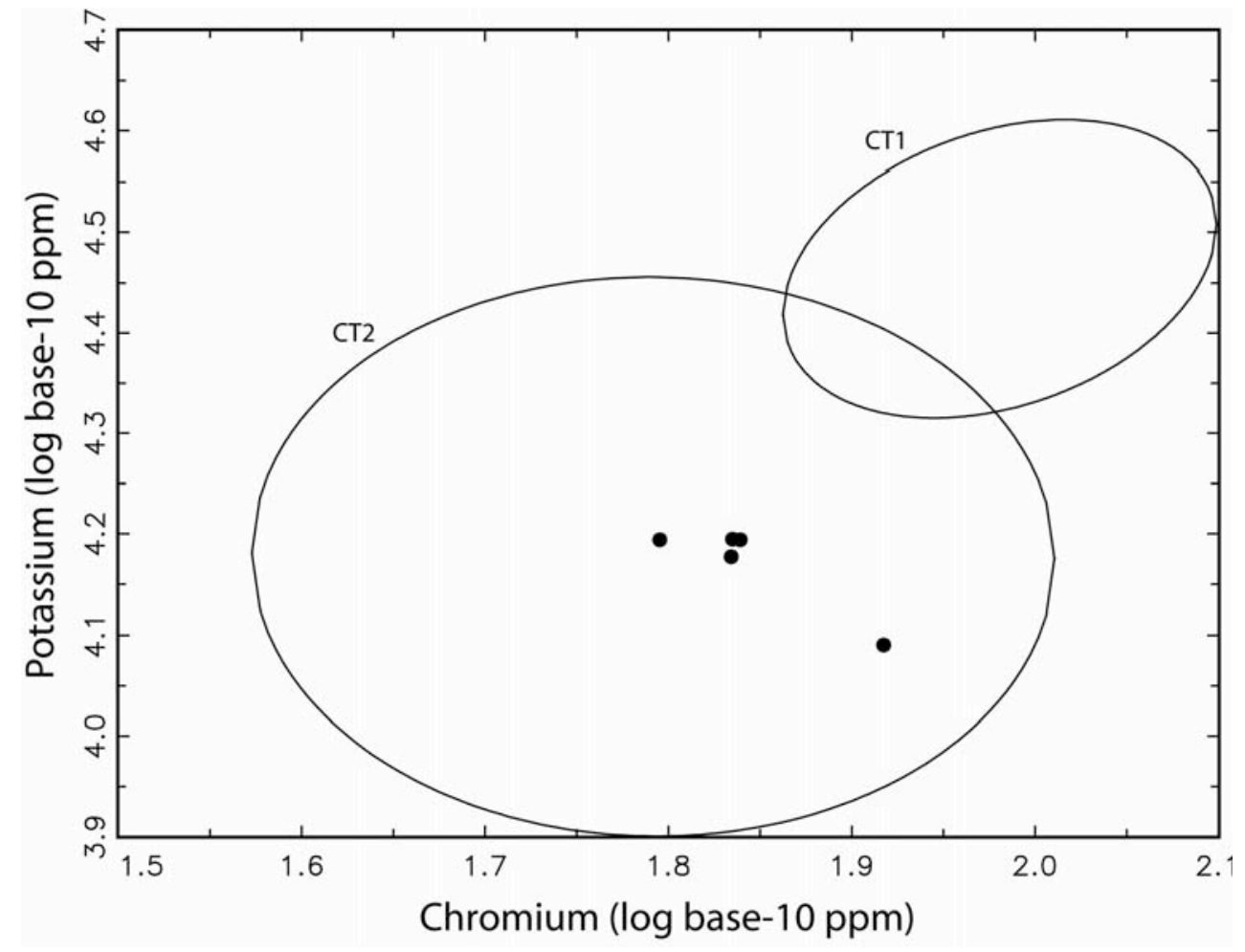

Figure 15. Bivariate plot of chromium and potassium (log base-10 ppm) showing the relationship between the main CT reference groups and the new samples from 41BQ285. The new samples are individually plotted. Ellipses represent $90 \%$ confidence intervals for membership in the groups. 
the petrographic findings. In particular, while grog tempering and hematite are present in the paste of sherd \#51 (and hematite is also present in sherds \#52, \#53-2, and \#53-3, see Perttula et al. 2010:Table 2) at 41BQ285-and are common constituents in East Texas Caddo pottery (Perttula 1999 (ed.):Table 9-14), particularly grog temper, but less so hematite inclusions - there are a number of examples in other Central Texas ceramic assemblages of demonstrably locally produced ceramic wares (i.e., Toyah phase wares, in the main) also containing both inclusions (see Black 1986; Green and Hester 1973; Highley 1986; Perttula 2009a, 2009b; Quigg and Peck 1995; Reese-Taylor 1995; Skelton 1977; Treece et al. 1993; Trierweiler 1996). The "grog" is typically described as fired clay lumps.

In the specific case of hematite, the occurrence of hematite in the paste of Caddo sherds, as detected in a number of petrographic analyses from East Texas Caddo sites in the Sabine, Sulphur, and Big Cypress stream basins, ranges from only 0.6-7.7 percent of the point counts, with a mean percentage of only 3.3 percent (Perttula 1999 (ed.):Table 9-14). Three of the four sherds from 41BQ285, including the engraved sherd (\#51) and two (\#53-2 and \#53-3) of the four other sherds rather convincingly shown by petrographic analysis and INAA to be considered to have come from Central Texas manufactured vessels, have higher hematite point count percentages (see Perttula et al. 2010:Table 2). The presence and proportion of hematite may not be a particularly robust measure of ceramic provenance or production locales.

What is intriguing about the engraved sherd from 41BQ285 is that it contains rock particles of igneous origin (Rock A in Perttula et al. 2010:Table 2). Three of the sherds in Paste Group 2-considered to represent sherds from vessels made with Central Texas clays - also have the same igneous rock particles in their paste. It is not to be expected that East Texas clays would contain igneous particles, as the geological formations in the region are the product of deposition of coastal parent materials, while parent materials in various parts of Central Texas are derived from igneous formations.

All things being equal, it is a curious finding that igneous rock particles are an inclusion in the engraved sherd (\#51) from 41BQ285. That finding, along with the fact that the same igneous rocks are found in most of the other sherds from the site that are considered to be from vessels made from Central Texas clays (Paste Group 2), when coupled with the INAA findings of a high probability of membership in the CT 2 chemical group, lends weight ultimately to the conclusion that this engraved sherd was from a vessel made from a Central Texas clay source. What prehistoric aboriginal group made this sherd remains to be determined.

The engraved sherd has a panel of diagonal engraved lines on the rim of the carinated bowl. This relatively simple geometric design is present on several defined Caddo pottery types, including Holly Fine Engraved, Sanders Engraved, and Spiro Engraved (see Suhm and Jelks 1962), although the engraved lines on Holly Fine Engraved and Spiro Engraved are typically finely executed, while the engraved lines on sherd \#51 are assuredly not finely executed. Such a geometric design on a carinated bowl form is probably also part of the decorative motifs on a number of typologically undefined Early and Middle Caddo pottery vessels and sherds in East Texas. No typological identification is attempted of the 41BQ285 sherds. The Early and Middle Caddo periods in East Texas range from ca. A.D. 1000-1400 in age (Story 1990a), and a Middle Caddo affiliation for the engraved sherd from 41BQ285, would be consistent with the recovery of both Perdiz points and several of the calibrated radiocarbon dates from the site.

Two body sherds (\#53-2 and \#53-3) have single fingernail punctations (see Table 8). Given the size of the sherds, the occurrence of only single fingernail punctates suggests that these two vessels must have had widely-spaced and/or freely-spaced fingernail punctations on the vessel body. 
Four of the five sherds from 41BQ285 are apparently tempered with grog or small amounts of crushed pieces of fired clay (see Table 9). Whether these pieces represent deliberately added crushed sherd fragments - as is so commonly seen in East Texas Caddo ceramic wares - or incidental inclusions incorporated in the clay paste during its preparation for vessel manufacture has not been determined. The absence of identified grog aplastics in the petrographic analysis of three of these four sherds suggest they the small pieces of apparent fired clay are probably incidental inclusions, and not deliberately added pieces of temper, except in the case of the grog-tempered engraved sherd (see Table 8). One of the fingernail punctated sherds has a sparse amount of burned bone temper. Grog is the preferred temper of choice for Caddo pottery throughout much of East Texas and for all temporal periods, particularly in the upper Neches, Sabine, Big Cypress, and Sulphur River basins. Shell-tempered pottery began to be manufactured by Caddo potters after ca. A.D. 1300 in much of the Red River basin in East Texas, while the use of bone as a temper was common around the same time in parts of the Neches and Angelina River basins (see Perttula 2011:Figure 6-70).

Three of the sherds have been burnished on one or both vessel surfaces, and the other two have smoothed vessel surfaces (see Table 9). The one carinated bowl sherd has been burnished on both vessel surfaces, and one fingernail punctated sherd has been smoothed on both vessel surfaces.

Three of the five sherds are from vessels fired in a reducing or low oxygen environment (probably smothered in a bed of coals from a wood fire). These vessels were subsequently exposed to air and/or cooled in a high oxygen environment (i.e., fire-hardened vessels were removed from the fire to cool), where either one or both vessel surfaces had thin oxidized or light-colored (red to reddish-brown) surface colors. Two sherds have a distinctive core, with a light exterior and core, except for a thin dark band along the interior surface (firing condition $\mathrm{K}$ on Table 9). These vessels with this kind of firing may have been placed in a fire with the "orifice [of the vessel] facing into the fire" (Aten and Bollich 2002:54-55). Furthermore, the sherds with cores lighter than one or both surfaces may have come from vessels where "after extended firing that burned off all organics, the fire may have been smothered to cause reduction and darkening of the exterior surface."

\section{$41 B Q 293$}

Two plain grit-tempered sherds from the same vessel (fired and cooled in a reducing environment and smoothed on the exterior), and found on the surface, were recovered in investigations of a Toyah phase component at 41BQ293 (Jones 2009:56-57 and Figure 8.7). The "grit" in the paste may be sand particles, or crushed rocks, but this is not mentioned in Jones (2009). INAA results suggest this vessel may have originated in East Texas, but this could not be determined with confidence.

\section{$41 B Q 295$}

The two plain grit-tempered sherds from 41BQ295 were analyzed by INAA, and the results suggest that the sherds are from vessels that may have also originated in East Texas (Jones 2009:92-93). One sherd was found on the surface and the other from 50-60 cm bs. Ferguson and Glascock (2009:273283) state that because of regional clay similarities between East Texas and parts of Central Texas, "it is not possible to confidently state that any of these samples are Caddo," but CT 2 INAA group is indistinguishable from the "Titus" INAA group (i.e., Sabine and Big Cypress areas of East Texas). 


\section{Ann's Cave}

Ann's Cave is a rock shelter in the North Bosque River valley, just north of the community of Valley Mills, Texas. In addition to well-preserved animal bones and perishable organic remains, three ancestral Caddo grog-tempered sherds are in the collection from the site at the Mayborn Museum Complex at Baylor University. One is a plain body sherd, another has three or more rows of fingernail punctations, and the last sherd has an exterior red-slipped and burnished surface.

\section{Brown County}

\section{$41 B R 307$}

The one grog-bone-tempered body sherd in the TARL collections from an ancestral Caddo vessel at this site has parallel engraved lines. Its age is uncertain, other than to postdate ca. A.D. 900.

\section{Burnet County}

\section{Grelle (41BT1)}

The Grelle site sherd collection at TARL has Leon Plain bone-tempered sherds, thick $(>10.0 \mathrm{~mm})$ plain bone-tempered ceramic sherds, and an ancestral Caddo plain body sherd. This sherd has grog temper and a sandy paste, and is $10.2 \mathrm{~mm}$ thick. The thickness of the sherd suggests it may be from a Williams Plain vessel, most commonly manufactured in the northern part of East Texas, as well as eastern Oklahoma, during the Woodland period (see Ellis 2013), although it was still being made in the Formative Caddo period (ca. A.D. 800-1000).

\section{Coke County}

\section{$41 C K 66$}

This Colorado River alluvial terrace site at the Humble Crossing Recreation Area at Lake Spence has eight brushed sherds from an ancestral Caddo manufactured jar. Found along with these vessel sherds was a possible Caddo bowl ( $\mathrm{n}=87$ sherds) from a bulldozed/stock tank area.

\section{Pavo Site (41CK120)}

The Caddo ceramic vessel sherds from the Pavo site include two plain body sherds from a grogtempered vessel and another sherd with appliqued elements, probably from a Late Caddo period, Titus phase, Harleton Appliqued vessel (see Shafer 1969:71 and Figure 39k-1). The Pavo site is located on an alluvial terrace of the Colorado River.

\section{Coleman County}

\section{Millard Collection}

Three sherds in the Millard Collection are from ancestral Caddo vessels. One is a plain grogtempered rim (INAA, UT00167), another is a Maydelle Incised body sherd with diagonal and opposed incised lines (INAA, UT00168), and a third is a grog-tempered body sherd from a Keno Trailed vessel with parallel trailed lines (INAA, UT00165). 


\section{Frank Mills Collection}

The Frank Mills collection from Coleman County has a brushed-punctated jar with an everted rim and small handles (Smith 1936:Plate 15:1). The rim has three horizontal rows of tool punctations above a vessel body with vertical brushing marks that extend to the vessel base. This ancestral Caddo vessel has been identified as Bullard Brushed by Suhm and Jelks (1962:Plate 11b).

\section{Concho County}

\section{Currie (41CC131)}

Aboriginal ceramic sherds were relatively common $(n=700)$ in Cultural Unit 2 at the Currie site (41CC131), located on an alluvial terrace of the Concho River a short distance upstream from its confluence with the Colorado River (Treece et al. 1993:119). Radiocarbon dates from this component date from the $16^{\text {th }}$ century A.D. (Treece et al. 1993:Table 4.23). Of the 700 sherds at the Currie site, there are two engraved sherds with parallel or vertical lines, at least one with an apparent red slip bounded by two engraved lines (Treece et al. 1993:Figure 4.34d-e, g). A third sherd is described as having crosshatched incised lines filled with red paint (Treece et al. 1003:208 and Figure 4.34f). It is much more likely that this sherd is engraved, and has had a red clay pigment rubbed in the engraved lines; this is a very common embellishment on Caddo fine ware ceramics in East Texas. Another body sherd has a series of vertical incised lines on the vessel body (Treece et al. 1993:Figure 4.34c). The decorative elements on these sherds are consistent with ancestral Caddo ceramics, and the fact that they are bone-tempered would not exclude them from consideration because bone-tempered ceramics were commonly produced by Caddo potters in the Sabine and Angelina river basins in East Texas.

Treece et al. (1993:207) also note that the assemblage has 16 bone-tempered sherds with grass or brush impressions. These sherds may also be from an ancestral Caddo vessel or vessels, perhaps originating in the Late Caddo bone-tempered brushed tradition wares made after ca. A.D. 1400 in the mid-Sabine and Angelina River basins (see Figure 9).

\section{Coryell County}

\section{Grimes-Houy Shelter (41CV17)}

The Grimes-Houy shelter is above a spring pool on a tributary of Horse Creek, itself a tributary to the Leon River (Figure 16); the confluence of Horse Creek and the Leon River is ca. $0.3 \mathrm{~km}$ to the west of the shelter (Miller and Jelks 1952:190). The shelter is ca. $18 \mathrm{~m}$ in length, 1.8-4.6 $\mathrm{m}$ in width, and width a ceiling height of 1.8-3.6 m. The River Basin Survey (RBS) archaeologists excavated in the shelter in January 1951.

A total of 26 ceramic sherds are in the TARL collections from the Grimes-Houy Shelter. Almost 70 percent $(n=18)$ are from vessels tempered with grog, and the remaining 31 percent are from grog-bonetempered vessels. Ten sherds are plain body sherds from either grog- $(n=5)$ or grog-bone-tempered $(n=5)$ vessels. The remaining 16 sherds are from the decorated portions of utility ware vessels. Miller and Jelks (1952:191) noted that Darl Hill had recovered sherds from a vessel "very similar to one from the Clements Site in Cass County [41CS25] which was found in association with European trade material. The fragments were found by Mr. Hill within a very restricted space and the vessel they represent was probably grave furniture included with one of the burials" at the site. Unfortunately, Miller and Jelks (1952) do not describe or illustrate the vessel sherds recovered by Mr. Hill. The Clements (41CS25) 


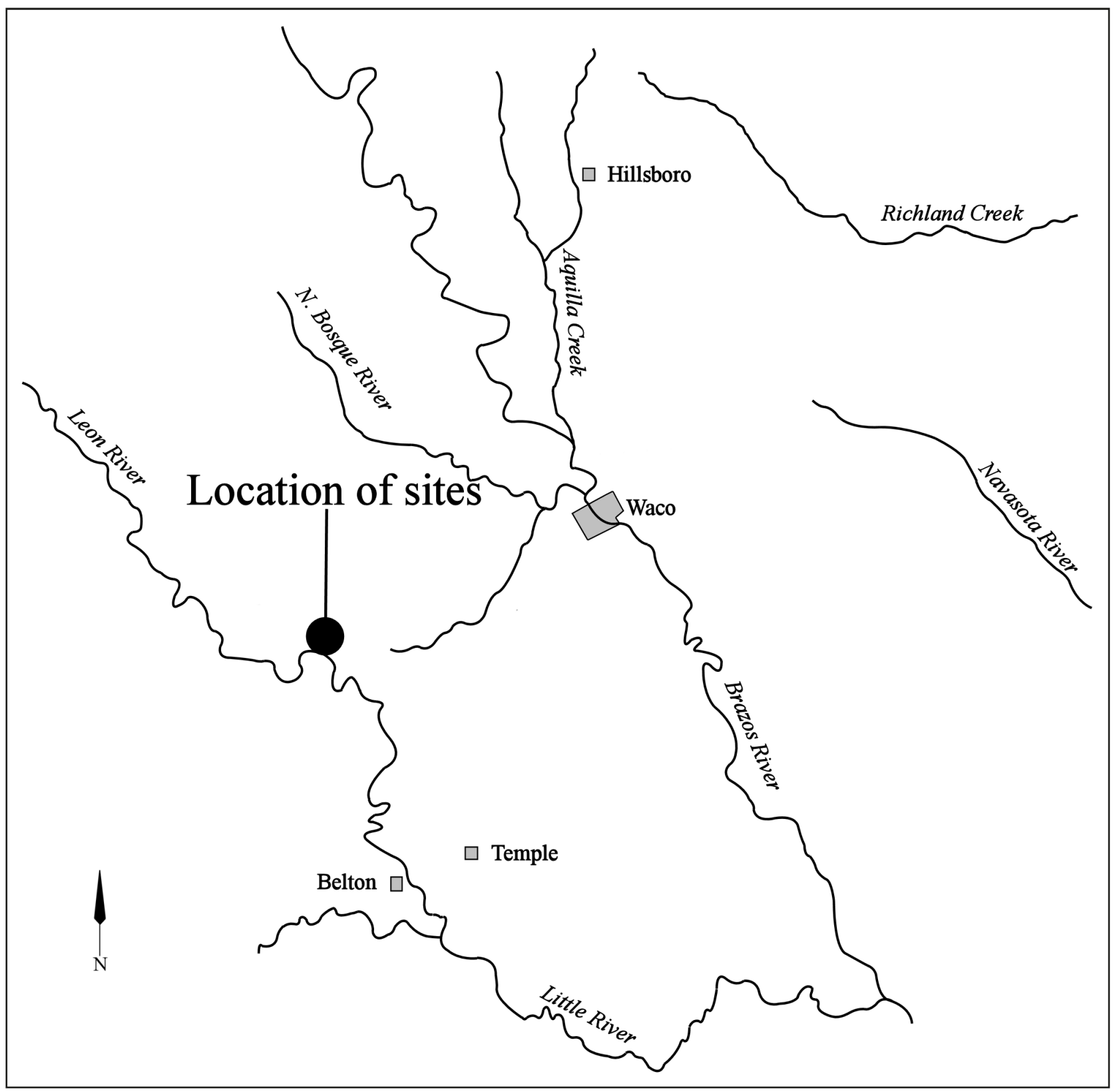

Figure 16. Location of the Grimes-Houy Shelter, Grimes-Houy Burned Rock Midden, and Ament Midden sites on the Leon River in Coryell County, Texas.

site is a Nasoni Caddo cemetery in the eastern part of the Big Cypress Creek basin in the East Texas Pineywoods. The decorative styles and distinctive vessel forms represented in the ceramic vessel assemblage from the site suggest that the burials dated from ca. A.D. 1680-1730, in the early Historic Caddo period (Perttula 2015b).

There are decorated body sherds with parallel brushing marks $(n=5)$, parallel brushed-incised marks and lines $(n=5)$, parallel brushing marks with parallel and overlying incised lines $(n=1)$, and parallel incised lines $(\mathrm{n}=2)$. These are likely from Maydelle Incised and Bullard Brushed vessels (Suhm and Jelks 1962). Three rim and upper body sherds have three horizontal rows of tool punctations on the rim and diagonal opposed brushed-incised marks and lines on the upper vessel body. Notably, about 88 percent of the decorated utility ware sherds from the Grimes-Houy Shelter are from brushed vessels. 


\section{Grimes-Houy Burned Rock Midden (41CV21)}

The Grimes-Houy Burned Rock Midden site is atop a canyon wall, ca. 60 m northwest of the GrimesHouy Shelter (Miller and Jelks 1952:192). The burned rock midden was ca. 15 x 9 m in length and width, with deposits a maximum of $0.6 \mathrm{~m}$ in depth. RBS excavations took place in February and March 1951. Miller and Jelks (1952:195) noted that the sherds recovered in the excavations were from 0-30 cm bs, and "all appear to be of Caddoan [sic] styles. Five sherds from one vessel were identified as type Holly Fine Engraved, and at least two more vessels were represented by a series of brushed and plain sherds." The Holly Fine Engraved vessel sherds were found in the top $30 \mathrm{~cm}$ of the burned rock midden, along with brushed and plain sherds (Miller and Jelks 1952:195); the presence of the Holly Fine Engraved as well as the brushed sherds indicate that the shelter was occupied in both ca. A.D. 900-1200 and post-A.D. 1200 times.

The TARL collection of ceramic vessel sherds from the Grimes-Houy Burned Rock Midden includes 67 sherds from plain, utility, and fine ware vessels (Table 10). About 61 percent of the sherds are from grog-tempered vessels, another 32.8 percent are from grog-bone-tempered vessels, and 6 percent are from bone-tempered vessels. There are also two ceramic pipe sherds in the collection from the site.

Table 10. Ceramic sherds from the Grimes-Houy Burned Rock Midden site (41CV21).

\begin{tabular}{lllll}
\hline Ware & Grog & Grog-Bone & Bone & N \\
\hline Plain & 18 & 14 & 1 & 33 \\
Utility & 15 & 6 & 2 & 23 \\
Fine & 8 & 2 & 1 & 11 \\
\hline Totals & 41 & 22 & 4 & 67 \\
\hline
\end{tabular}

The highest proportion of grog-tempered vessels occur among the fine wares (72.7 percent), while the highest proportion of grog-bone-tempered sherds are in the plain wares ( 42.4 percent). Bone-tempered sherds are equally abundant in both the utility wares ( 8.7 percent) and the fine wares ( 9.1 percent) (see Table 10).

The 34 decorated sherds from the Grimes-Houy Burned Rock Midden are from utility ware (68 percent) and fine ware (32 percent) vessels. Sixty percent of the rim sherds are from utility wares and the remaining 40 percent are from fine wares (Table 11).

Table 11. Decorative methods and elements represented in the utility ware and fine ware sherds from the Grimes-Houy Burned Rock Midden (41CV21).

\begin{tabular}{llll}
\hline Decorative method/element & Rim & Body & $\mathrm{N}$ \\
\hline
\end{tabular}

\section{Utility Ware}

\section{Brushed}

parallel brushing marks

$--$


Table 11. Decorative methods and elements represented in the utility ware and fine ware sherds from the Grimes-Houy Burned Rock Midden (41CV21), continued.

\begin{tabular}{|c|c|c|c|}
\hline Decorative method/element & Rim & Body & $\mathrm{N}$ \\
\hline \multicolumn{4}{|l|}{ Incised } \\
\hline diagonal incised lines & 1 & 2 & 3 \\
\hline diagonal opposed incised lines & 1 & 2 & 3 \\
\hline parallel incised lines, broad lines & - & 1 & 1 \\
\hline parallel incised lines, widely-spaced & - & 2 & 2 \\
\hline straight incised line & - & 1 & 1 \\
\hline vertical and diagonal opposed incised lines & - & 1 & 1 \\
\hline \multicolumn{4}{|l|}{ Incised-Punctated } \\
\hline diagonal opposed incised lines above row of tool punctates & - & 1 & 1 \\
\hline $\begin{array}{l}\text { horizontal crescent-shaped fingernail punctated rows between } \\
\text { horizontal incised lines }\end{array}$ & - & 3 & 3 \\
\hline $\begin{array}{l}\text { horizontal crescent-shaped fingernail punctated rows between } \\
\text { horizontal incised lines on rim and fingernail punctated rows } \\
\text { on the vessel body }\end{array}$ & 1 & - & 1 \\
\hline incised triangle filled with tool punctated rows & 1 & - & 1 \\
\hline $\begin{array}{l}\text { incised triangle filled with tool punctated rows and separate } \\
\text { vertical rows of tool punctations }\end{array}$ & 1 & - & 1 \\
\hline \multicolumn{4}{|l|}{ Pinched } \\
\hline parallel pinched rows & - & 1 & 1 \\
\hline \multicolumn{4}{|l|}{ Punctated } \\
\hline fingernail punctated rows & - & 2 & 2 \\
\hline tool punctated rows on the rim & 1 & - & 1 \\
\hline
\end{tabular}

\section{Fine Ware}

\section{Engraved}

closely-spaced parallel engraved lines cross-hatched and diagonal opposed engraved lines curvilinear engraved lines* curvilinear engraved line and curvilinear cross-hatched zone curvilinear engraved lines and curvilinear hatched zone horizontal and diagonal engraved lines horizontal and diagonal opposed engraved lines row of engraved triangle elements horizontal engraved lines and hatched zones

\begin{tabular}{ccc} 
& 1 & 1 \\
& - & 1 \\
& 1 & 1 \\
1 & 1 \\
1 & 1 \\
& - & 2 \\
& 2 & 2 \\
1 & - & 1 \\
\hline & 24 & 34
\end{tabular}

Totals

*Bottle sherd 
The most distinctive of the utility ware sherds from the Grimes-Houy Burned Rock Midden are the rim and body sherds from Early Caddo period Weches Fingernail Impressed, var. Weches (see Stokes and Woodring 1981:184-185) jars. These vessel sherds have horizontal incised panels on the rim filled with single rows of crescent-shaped fingernail punctations (Figure 17a-b) One Weches Fingernail Impressed, var. Weches rim and upper body sherd also has rows of fingernail punctations on the upper body (Figure 17c).

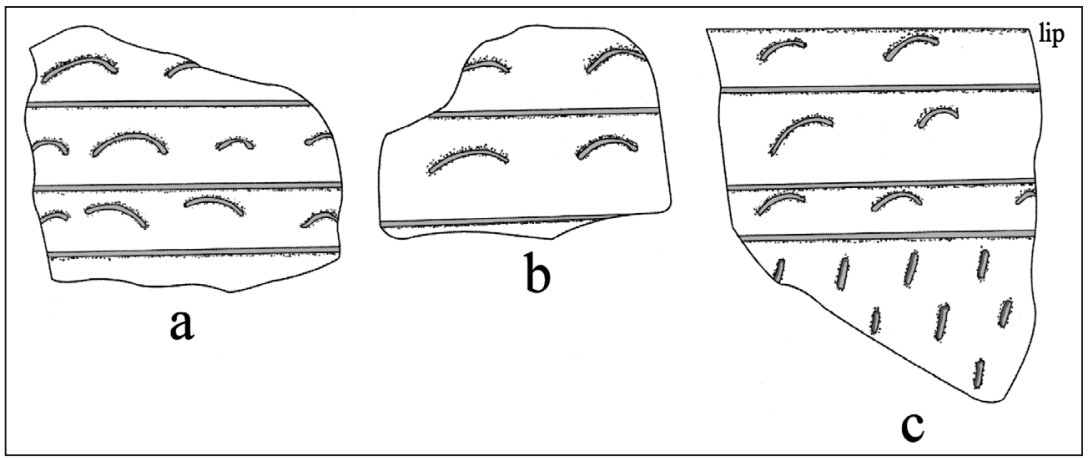

Figure 17. Weches Fingernail Impressed sherds from the GrimesHouy Burned Rock Midden site.

Dunkin Incised rim and body sherds are also common in the utility wares. These include rim and body sherds with diagonal opposed incised lines (Figure 18a-c), and another body sherd with diagonal opposed incised lines that originate along a vertical incised line (Figure 18d). One other Dunkin Incised sherd has closely-spaced diagonal opposed incised lines on the rim above a single row of tool punctations at the rim-body juncture (Figure 18g). Other Dunkin Incised sherds in the Grimes-Houy Burned Rock Midden collection have diagonal incised lines pitched from left to right across the rim.

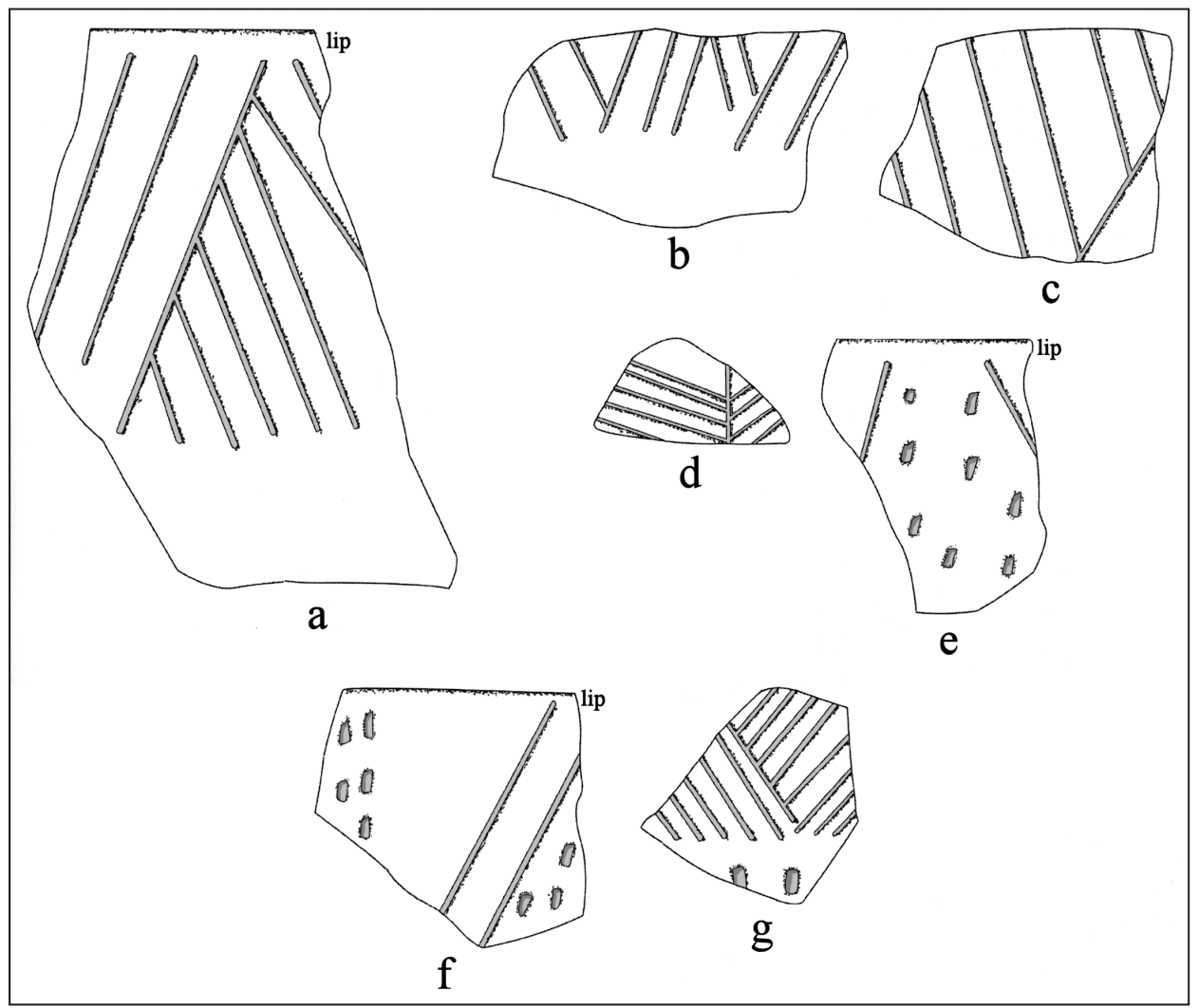

Figure 18. Selected decorative elements on utility ware sherds from the Grimes-Houy Burned Rock Midden site. 
Two incised-punctated rim sherds have triangular incised zones filled with rows of tool punctations (see Figure 18e-f). Three rim and body sherds have rows of either tool or fingernail punctations (see Table 10). One sherd, probably from a Hollyknowe Pinched vessel (cf. Webb and McKinney 1975), or less likely from a Killough Pinched vessel, has parallel rows of pinched ridges. Lastly, there is a single body sherd in the collection from a Bullard Brushed vessel with parallel brushing marks.

The fine ware sherds in the Grimes-Houy Burned Rock Midden ceramic assemblage (see Table 11) are from engraved bottles, bowls, and carinated bowls. The one engraved bottle sherd has sets of fine curvilinear engraved lines (Figure 19e), and it likely from a Holly Fine Engraved bottle (see Suhm and Jelks 1962:Plate 40e, g). Carinated bowl rim sherds have horizontal and diagonal engraved lines (Figure 19a), cross-hatched and diagonal opposed engraved lines, horizontal and diagonal opposed engraved lines (Figure 19d), as well as horizontal engraved lines with pendant hatched zones (Figure 19b).

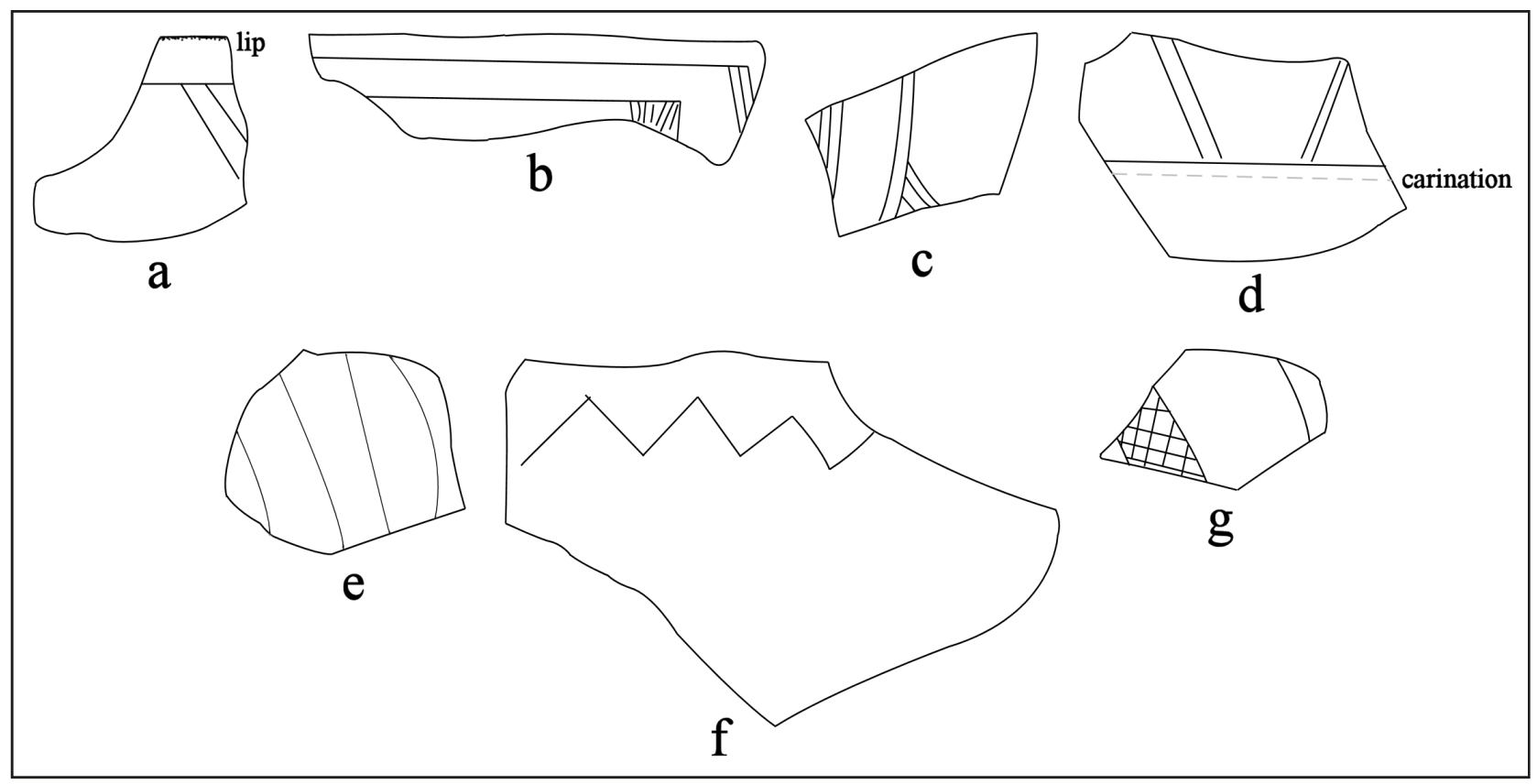

\section{Figure 19. Selected decorative elements on fine ware sherds from the Grimes-Houy Burned Rock Midden site.}

A large grog-tempered bowl rim sherd from the site has a single row of engraved triangle elements (see Figure 19f). Another grog-tempered vessel sherd is decorated with a curvilinear engraved line as well as a narrow curvilinear engraved zone filled with finely engraved cross-hatched engraved lines (see Figure 19g). One body sherd has curvilinear engraved lines and a curvilinear hatched zone (see Figure 19c), and these decorative elements resemble the decorative elements on a Poynor Engraved, var. Cook vessel (see Perttula 2011:Figure 6-64).

The first of the pipe sherds from the Grimes-Houy Burned Rock Midden is a plain and grog-tempered long-stemmed pipe stem and bowl fragment $6.1 \mathrm{~mm}$ in thickness. This sherd may be from an Early Caddo period Graves Chapel variety of the Red River pipe (Hoffman 1967:9). The second sherd is from a bone-tempered elbow pipe, and it comprises much of the elbow pipe bowl (Figure 20). The elbow pipe is at least $45 \mathrm{~mm}$ in height, has a $26.5 \mathrm{~mm}$ orifice diameter, a flat lip, with bowl walls that are $5.4 \mathrm{~mm}$ thick. The pipe bowl is decorated with three discontinuous horizontal engraved lines at the top of the bowl 
(Figure 20), analogous to the Var. B elbow pipe form found in upper Neches River basin Caddo sites dating from ca. A.D. 1400-1560 (Perttula 2011:215 and Figure 6-23), except that the Grimes-Houy Burned Rock Midden pipe has a much taller bowl.

\section{Urbankte (41CV26)}

The Urbankte site is on the Leon River in Coryell County, at Belton Reservoir; the Leon River is a southward-flowing tributary to the Brazos River (Miller and Jelks 1952) (Figure 21). The Urbankte site ceramics ( $\mathrm{n}=118$ sherds) examined at TARL were heavily bone-tempered ( 88 percent) and had a considerable proportion of brushed sherds (46 percent of the decorated sherds) (Perttula 2015); Miller and Jelks (1952:190) noted that ceramic sherds were "unusually numerous for a Central Texas site." Both characteristics were consistent with a post A.D. 1200-1300 Prairie Caddo occupation, as was the fact that eight of the nine arrow points in the TARL collections from the Urbankte site are Perdiz arrow points. The common occurrence of both Perdiz points and brushed ceramic sherds (see Perttula 2013) suggested then that this reputed Prairie Caddo occupation at the Urbankte site took place sometime after ca. A.D. 1200-1300.

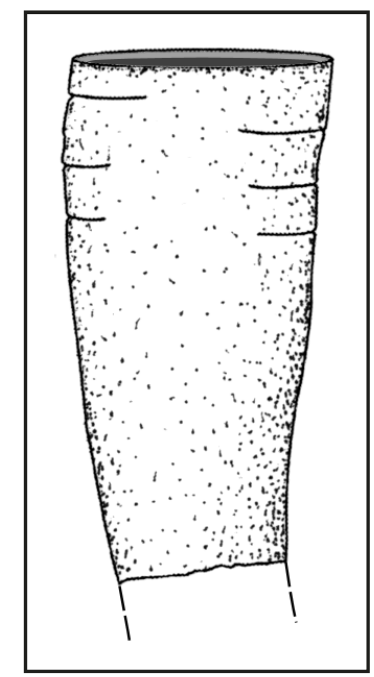

Figure 20. Elbow pipe bowl rim sherd from the GrimesHouy Burned Rock Midden site.

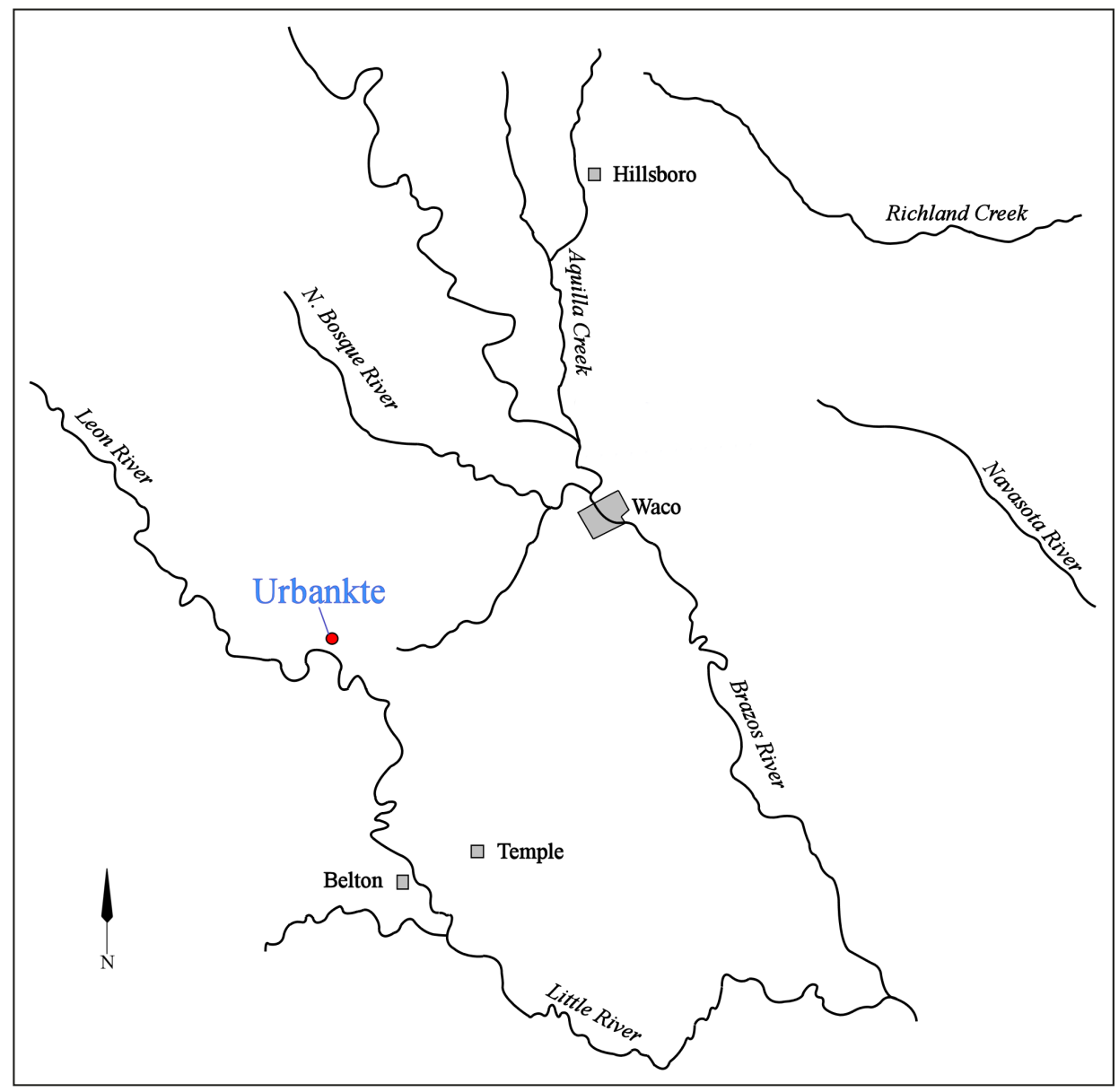

Figure 21. Location of the Urbankte site in the Leon River basin in Coryell County, Texas. 
The 118 ceramic sherds in the TARL collections are from both plain ware, utility ware, and fine ware bowls and jars (Table 12). According to Miller and Jelks (1952:190), "[m]ost of the sherds are too fragmentary for positive typological identification, but the ceramic assemblage as a whole is unquestionably Caddoan [sic]." The two plain ware rims have direct profiles and rounded lips. The bone and grog temper in the vessel sherds was described as large in size and coarse, not finely crushed, as would be common in East Texas Caddo wares.

Table 12. Ceramic artifacts from the Urbankte site (41CV26) in the TARL collections.

\begin{tabular}{|c|c|c|c|}
\hline Ware & grog-tempered & bone-tempered & $\mathrm{N}$ \\
\hline \multicolumn{4}{|l|}{ Plain Ware } \\
\hline plain rim & - & 2 & 2 \\
\hline plain body & 11 & 88 & 99 \\
\hline base & 1 & 3 & 4 \\
\hline \multicolumn{4}{|l|}{ Utility Ware } \\
\hline Brushed & 2 & 4 & 6 \\
\hline Incised & - & 2 & 2 \\
\hline Punctated & - & 2 & 2 \\
\hline \multicolumn{4}{|l|}{ Fine Ware } \\
\hline Engraved & - & 3 & 3 \\
\hline Totals & 14 & 104 & 118 \\
\hline
\end{tabular}

Forty-six percent of the decorated sherds are from brushed vessels (see Table 11). These include a rim (direct profile with a rounded, exterior folded lip) with horizontal brushing marks (Bullard Brushed), and body sherds with parallel $(n=4)$ and overlapping $(n=1)$ brushing marks on utility ware jar bodies. Both incised sherds have parallel incised lines. The two punctated sherds both have rows of circular punctations.

The principal decorated rim and body sherds are from Pennington Punctated-Incised vessels with zoned incised diagonals and triangular elements filled with triangular-shaped tool punctations (Figure 22). There are also likely body sherds from contemporaneous Davis Incised and Dunkin Incised vessels (see Suhm and Jelks 1962) in the collection. There are three engraved fine ware sherds of unidentified type in the Urbankte site ceramic collection (see Table 11 and Figure 23), all from bone-tempered vessels. Two have either parallel or straight lines, while the third sherd has horizontal and vertical opposed engraved lines; these may be the three sherds identified as Holly Fine Engraved by Miller and Jelks (1952:190). The ceramic sherds from the earlier Prairie Caddo component at the Urbankte site are from a ca. A.D. 900-1200 occupation.

In addition to ceramic artifacts, there are nine arrow points in the TARL collections from the Urbankte site. They include eight Perdiz arrow points and one Scallorn arrow point on local Central Texas cherts. The common occurrence of both Perdiz points and brushed ceramic sherds suggests that at least part of the occupation at the Urbankte site took place sometime after ca. A.D. 1200-1300. 


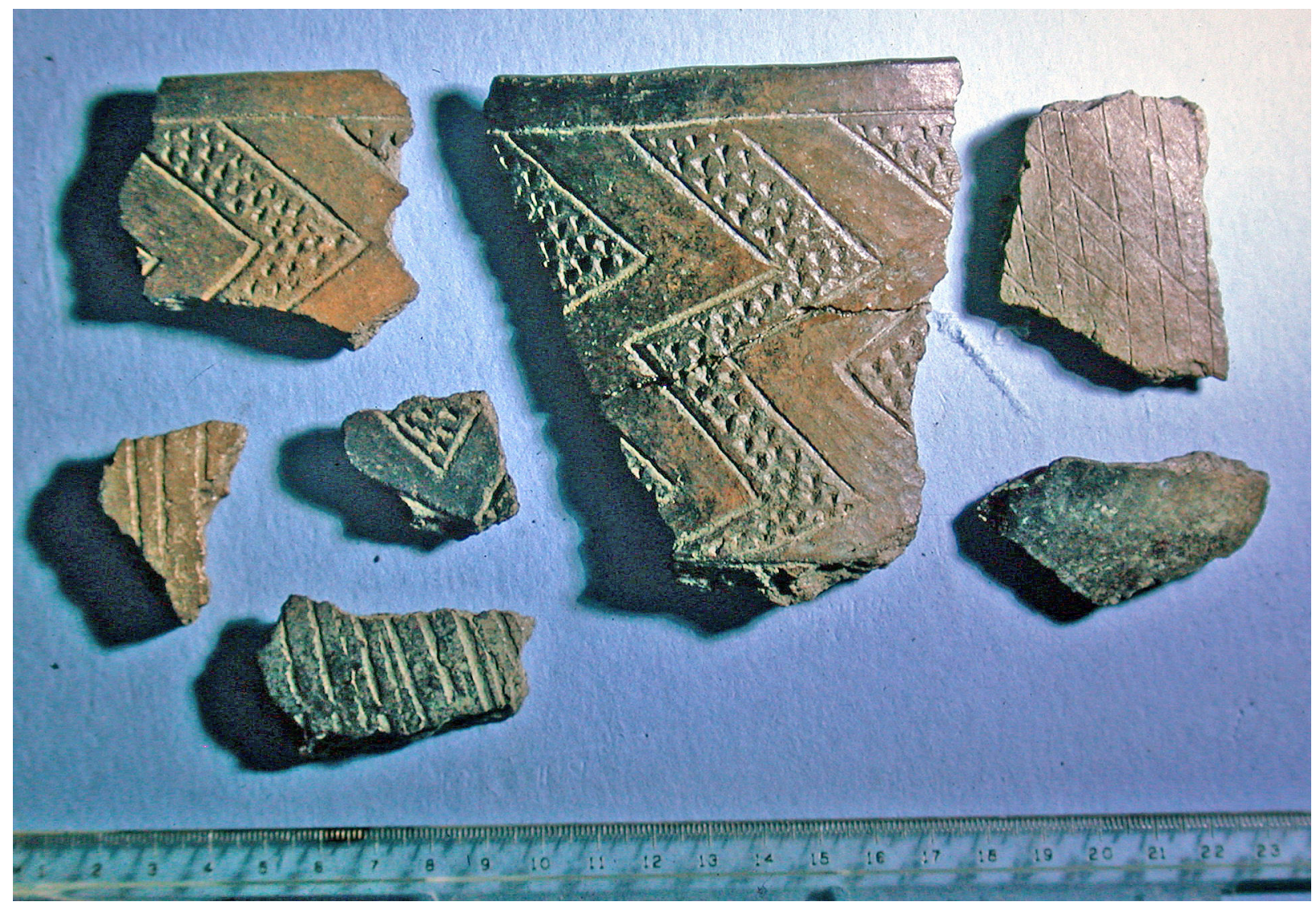

Figure 22. Early Caddo period ceramic sherds from the Urbankte site.

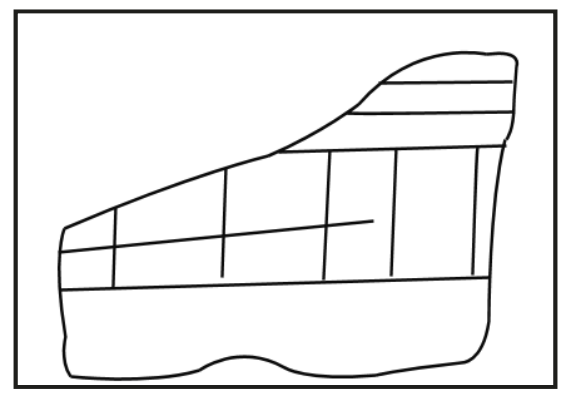

Figure 23. Engraved body sherd from the Urbankte site.
Shafer's collection of ceramic sherds from the Urbankte site (Perttula and Shafer 2016:48) came from a component shallowly buried in the bank of Horse Creek. The ceramic sherds from the earlier Prairie Caddo component at the Urbankte site are from a ca. A.D. 900-1200 occupation. The principal decorated rim and body sherds are from Pennington Punctated-Incised vessels with zoned incised diagonals and triangular elements filled with triangular-shaped tool punctations (see Figure 22). There are also likely body sherds from contemporaneous Davis Incised and Dunkin Incised vessels (see Suhm and Jelks 1962) in the collection.

In summary, the Urbankte site was evidently occupied by Prairie Caddo groups on at least two occasions, one between ca. A.D. 900-1200 (contemporaneous with the Early Caddo period in East Texas) and the other sometime after ca. A.D. 1200-1300, contemporaneous with either the Middle or Late Caddo periods in East Texas. The earlier of the two components had early Caddo period ceramic sherds from Pennington Punctated-Incised and Davis Incised vessels, Bonham-Alba arrow points, and a Gahagan biface. The later component at the Urbankte site was characterized by numerous Perdiz arrow points, many bone-tempered ceramic vessels, and a considerable proportion of brushed sherds from utility ware vessels. 


\section{Ament Shelter (41CV33)}

Ancestral Caddo ceramics were recovered in excavations by Darl Hill, not by the River Basin Surveys (Miller and Jelks 1952:198). Ceramic sherds from the shelter included several from Holly Fine Engraved vessels (Miller and Jelks 1952:Plate 29:1-6), as well as sherds from at least one other vessel (although not specified by Miller and Jelks [1952:201). They do illustrate a Late Caddo Frankston phase decorated elbow pipe recovered by Hill (Miller and Jelks (1952:Plate 29:8), namely a Var. B ceramic elbow pipe bowl (Var. B, see Perttula 2011) from the shelter.

\section{Ament Midden (41CV34)}

This Leon River site had been looted by Darl Hill in the early 1950s. In 1959, Harry J. Shafer visited the site on several occasions, and excavated a $1 \mathrm{x} 1 \mathrm{~m}$ unit in the large burned rock midden; the midden was across from the Ament Shelter (41CV33); as mentioned above, there were ceramic sherds found in the shelter deposits as well as a ceramic pipe (Miller and Jelks 1952:201). Caddo ceramic sherds were recovered by Shafer from the midden excavations (Harry J. Shafer, August 12, 2015 personal communication), and the collections were subsequently donated to TARL. A ceramic pipe bowl sherd was also found in the site by another collector.

The collection of ceramic vessel sherds from the Ament Midden site at TARL includes 16 sherds from grog- $(n=10)$, grog-bone- $(n=3)$, and bonetempered $(n=3)$ vessels. Eleven sherds are plain, among them four rims, six body sherds, and one grog-bone-tempered base sherd; one of the rims is from a carinated bowl.

The five decorated sherds are body sherd from grog-tempered utility ware vessels. One body sherd has a circular appliqued node, one sherd has parallel incised lines, another sherd has parallel incised lines above a row of tool punctations, a body sherd with rows of fingernail punctations, and a body sherd with a set of curvilinear incised lines (Figure 24).

\section{CV41-A}

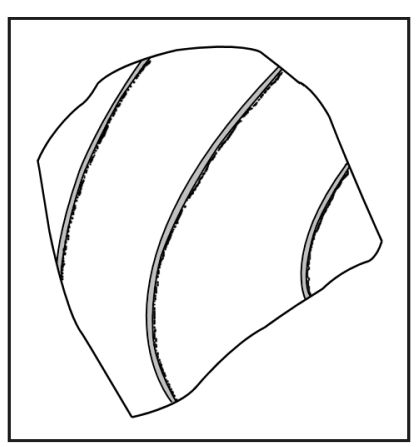

Figure 24. Decorative elements on incised body sherd from the Ament Midden site.

Aboriginal sites with ceramic sherds at Fort Hood are not at all common, with less than 150 sherds known from only 12 archaeological sites, or about 1 percent of the sites recorded on the fort (Weinstein 2015:24 and Table 3-4) at the facility; two sites (41BL183 and 41CV144) have more than 70 percent of the sherds. Both Toyah phase Leon Plain and ancestral Caddo ceramic wares are present in these assemblages, beginning ca. A.D. 900 in the case of Caddo wares, and after ca. A.D. 1200 in the case of the bone-tempered Toyah phase wares. Several sites have engraved Caddo wares that were made between ca. A.D. 900-1600.

41CV41-A is on the Fort Hood Military Reservation in the Leon River basin, and has a Toyah phase component. There are ancestral Caddo ceramic vessel sherds from two different vessels, one rim sherd from an incised vessel (Abbott and Trierweiler 1995:Table 8-17), and seven sherds from a grog-hematitetempered Taylor Engraved bottle with cross-hatched engraved zones and curvilinear scroll lines with pendant triangles (Figure 25). If accurately identified, Taylor Engraved vessels in East Texas Caddo sites (commonly found in sites in the Big Cypress Creek basin and parts of the Red River basin) were apparently made and used between ca. A.D. 1550-1680. 


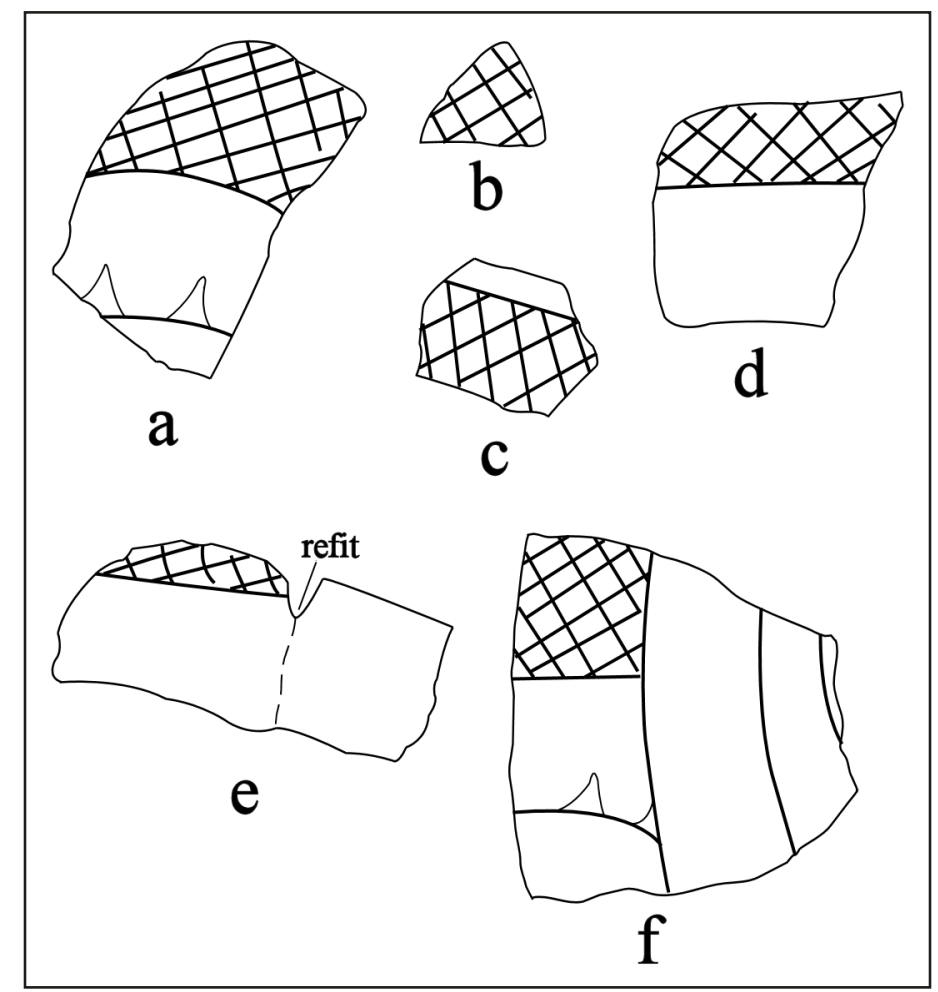

Figure 25. Taylor Engraved bottle sherds from 41CV41-A.

$41 C V 48$

This aboriginal site at Fort Hood is on an alluvial terrace of Owl Creek in the Leon River basin. Excavations recovered sherds from two different vessels in a Toyah phase component, including eight sherds from a thick grog-tempered parallel brushed vessel (Trierweiler 1996:168 and Figure 5.56). Petrographic analysis of the brushed vessel indicates that it is an ancestral Caddo vessel, likely a Bullard Brushed vessel, and Trierweiler (1996:168-169) suggests that the brushed sherds may represent use of the Fort Hood area by "peoples from Northeastern Texas who made brushed ceramics with grog additives. Alternately, the latter may have been a trade vessel as there is no indication of peoples from the northeastern region." Trierweiler (1996:573) goes on to speculate about whether the brushed ceramics are from "either an East Texas influenced Toyah group or an actual utilization of the Fort Hood area by an East Texas group."

\section{Stone Rockshelter (41CV61)}

Fifteen sherds recovered in excavations at the Stone Rockshelter on Hog Creek include five grogtempered sherds that are either exterior burnished or have incised elements from a Maydelle Incised vessel. One sandy paste sherd has exterior brushing marks (Henry et al. 1980). The brushed sherd and Maydelle Incised vessel sherd suggests the occupation at the rockshelter postdates ca. A.D 1200, and most likely dates to the time of the Frankston phase in East Texas, after ca. A.D. 1400.

\section{L.F. Robertson Shelter (41CV62)}

The eight sherds recovered from the archaeological deposits at the L. F. Robertson Shelter include grog-tempered and sandy paste wares. The few decorated sherds are from post-A.D. 1200 Caddo Bullard Brushed jars (Henry et al. 1980). 


\section{Unreported Fort Hood Site in the Vicinity of $41 \mathrm{CV} 92$}

A single grog-tempered rim sherd from a carinated bowl was reported by Thomas (1978:208; see also Perttula 2003:21) from a bluff slope landform near the south bank of the Leon River, and ca. $2 \mathrm{~km}$ northwest of 41CV92. The rim panel has a set of vertical columns that are either filled with cross-hatched lines or open, along with larger areas filled with a series of semicircular engraved lines (Figure 26). The combination of vertical panels and semi-circular engraved lines is a notable feature of Middle Caddo period sites in the middle Sabine River basin, as well as certain later Poynor Engraved motifs and elements seen on upper Neches River basin ceramic vessels (see Perttula 2011:Figure 6-65).

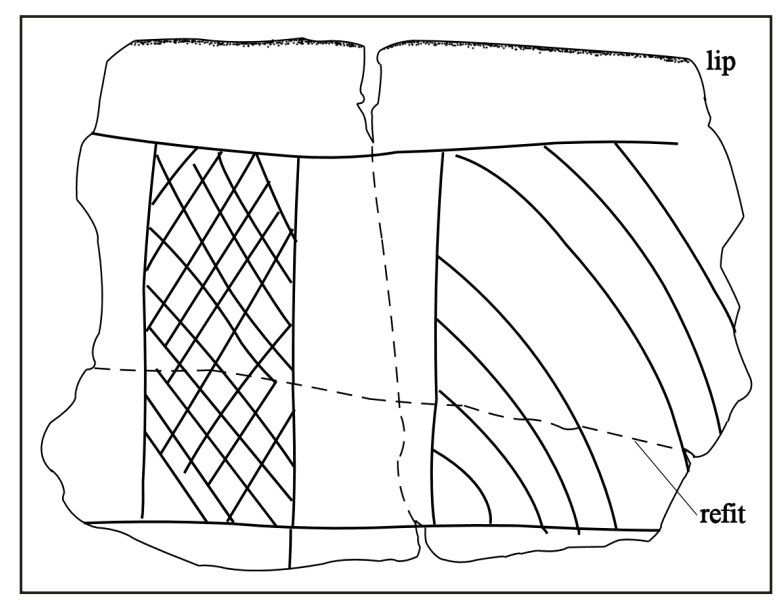

Figure 26. Decorative elements on engraved rim sherd from unreported site near 41CV92.

\section{$41 C V 344$}

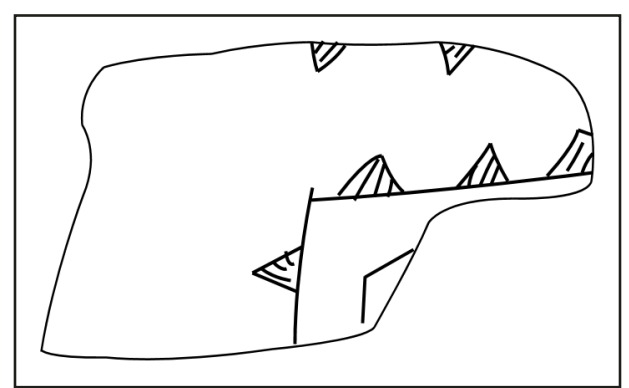

Figure 27. Engraved bottle sherds from Vessel 4 at $41 \mathrm{CV} 344$. engraved bottle has been recovered at the Asa Warner site on the Brazos River in ca. A.D. 1200-1400 archaeological deposits (see Turner 1997:Figure 10), as well as from Middle Caddo period contexts in sites in both the middle Sabine and upper Neches River basins in East Texas.

\section{$41 C V 960$}

This site, on a terrace of Cowhouse Creek at Fort Hood, has a single grog-tempered ancestral Caddo ceramic sherd (Abbott and Trierweiler 1995:491). The sherd is plain, but polished on both vessel surfaces, suggests it is from a carinated bowl. Petrographic analysis by Reese-Taylor (1995) "suggests it was a Caddoan [sic]-influence or traded, Caddoan [sic] grog-tempered vessel" (Abbott and Trierweiler 1995:491).

\section{$41 C V 1038$}

According to Mehalchick et al. (2003:243), eight brushed ceramic vessel sherds have been recovered in investigations at this site at Fort Hood. Found along with the brushed sherds was a single plain bonetempered sherd. 


\section{Watt's Sites No. 10-12}

In a list of aboriginal sites in the central Brazos River basin with ceramic sherds, Watt (1953:84 and Figure 26) lists three sites in the Leon River basin that have ancestral Caddo ceramic vessels. These are No. 10 on Coryell Creek, No. 11 on the Leon River, and No. 12 on a tributary of the Leon River. Between them, the three sites had 13 sherds from post-A.D. 1400 Late Caddo Frankston phase vessels of the Poynor Engraved and Bullard Brushed types.

\section{Chrisner's Ranch}

The Chrisner's ranch site is in southern Coryell County, on an alluvial landform in the Leon River basin (Marcus Whittle, 2017 personal communication). Ancestral Caddo ceramic vessel sherds of apparent Late Caddo, Frankston phase affiliation have been found in three areas of the site. Ceramic sherds known to come from Locality I include three grog-tempered body sherds, one with parallel to overlapping brushed marks (Bullard Brushed) and two with parallel incised lines. Locality II has 20 ancestral Caddo grog $(n=14)$ and grog-bone $(n=6)$-tempered sherds. Fourteen body sherds have parallel brushing marks, two has opposed brushing marks, and one has overlapping brushing marks. All of these are from Bullard Brushed vessels, as well as a lower rim-body sherd with a thumbnail punctated row at the rim-body juncture and horizontal-diagonal brushing on the vessel body.

Locality III has 15 sherds from a single Hume Engraved short-necked bottle (Figure 28a). The bottle is tempered with grog and bone, and has been fired and cooled in a reducing environment. Vessel walls are $10.2 \mathrm{~mm}$ thick. The engraved design consists of two sets of closely-spaced horizontal engraved lines under the lip and at the base of the neck. Between these, and then bisecting them, are several sets of vertical engraved lines (Figure 28b) and a single zig-zag engraved line. If this vessel was made in the upper Neches River basin, which is likely given the distinctive vessel shape (see Suhm and Jelks 1962:Plate 42e), it signifies use of the Chrisner's ranch site after ca. A.D. 1480, when Hume Engraved vessels began to be commonly made and used by ancestral Caddo peoples in this part of East Texas (see Perttula 2011).

It addition to the brushed and engraved sherds in the Chrisner's Ranch ceramic assemblage, there is another utility ware in the collection from the site, but its Locality is not known. This sherd is from a Maydelle Incised jar with incised triangles filled with diagonal opposed incised lines (Figure 29).

\section{$C-34$}

This unrecorded site is a rock shelter in the Leon River basin in Coryell County that was investigated by Cecil Calhoun in 1947; he also investigated nearby 41CV20, a rock shelter with a Perdiz arrow point and perishable artifacts (in the collections of the Texas Archeological Research Laboratory (TARL), but containing no ancestral Caddo ceramic vessel sherds. A June 1967 letter from Calhoun to TARL indicates that "a few East Texas sherds have been found" in the C-34 rock shelter deposits. Unfortunately, no details were provided by Calhoun concerning the kinds of vessel sherds they were.

\section{Gun Cornfield (39C3-3/C3-15)}

There are seven rim and body sherds from ancestral Caddo vessels in Frank Watt's collection from the Gun Cornfield site. Five of the sherds are plain, including a grog-tempered rim sherd and four body sherds; these are from grog- $(n=3)$ and bone- $(n=1)$ tempered vessels. One of the two decorated sherds is a grog-tempered body sherd from a Bullard Brushed vessel with parallel brushing marks, and the other 
$\mathbf{a}$

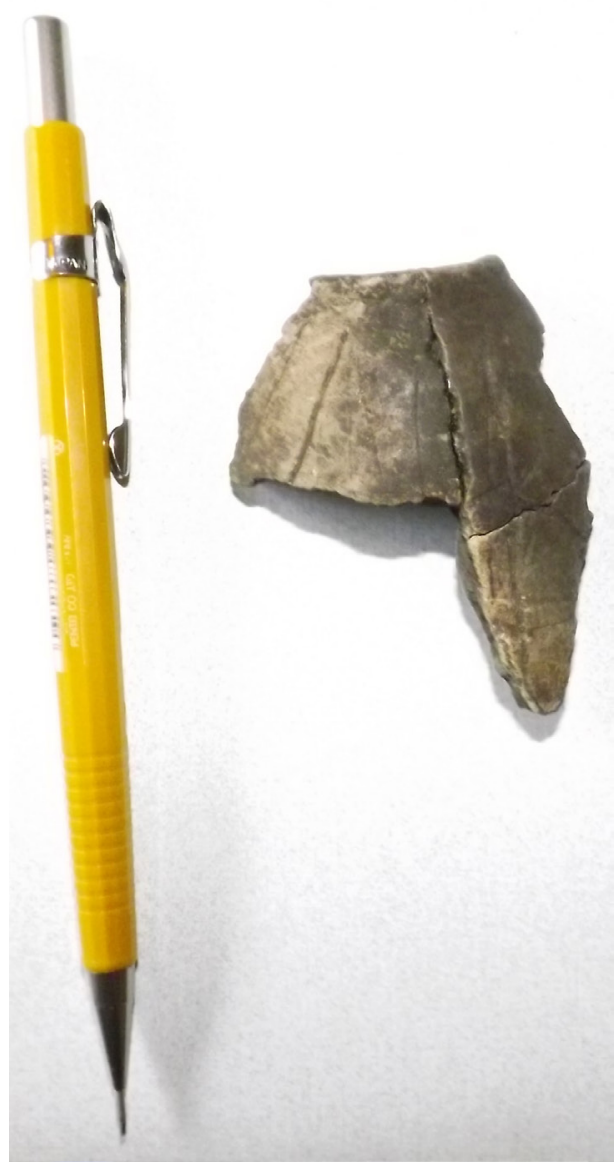

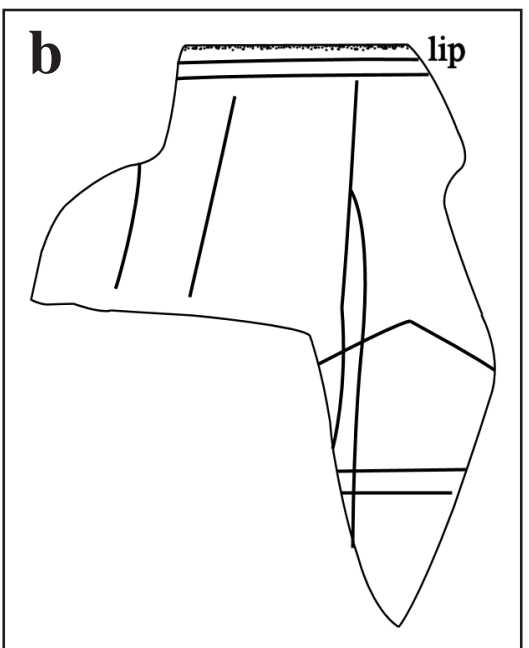

Figure 28. Hume Engraved bottle sherds from the Chrisner's Ranch site: a, photo image; $b$, drawing of decorative elements.

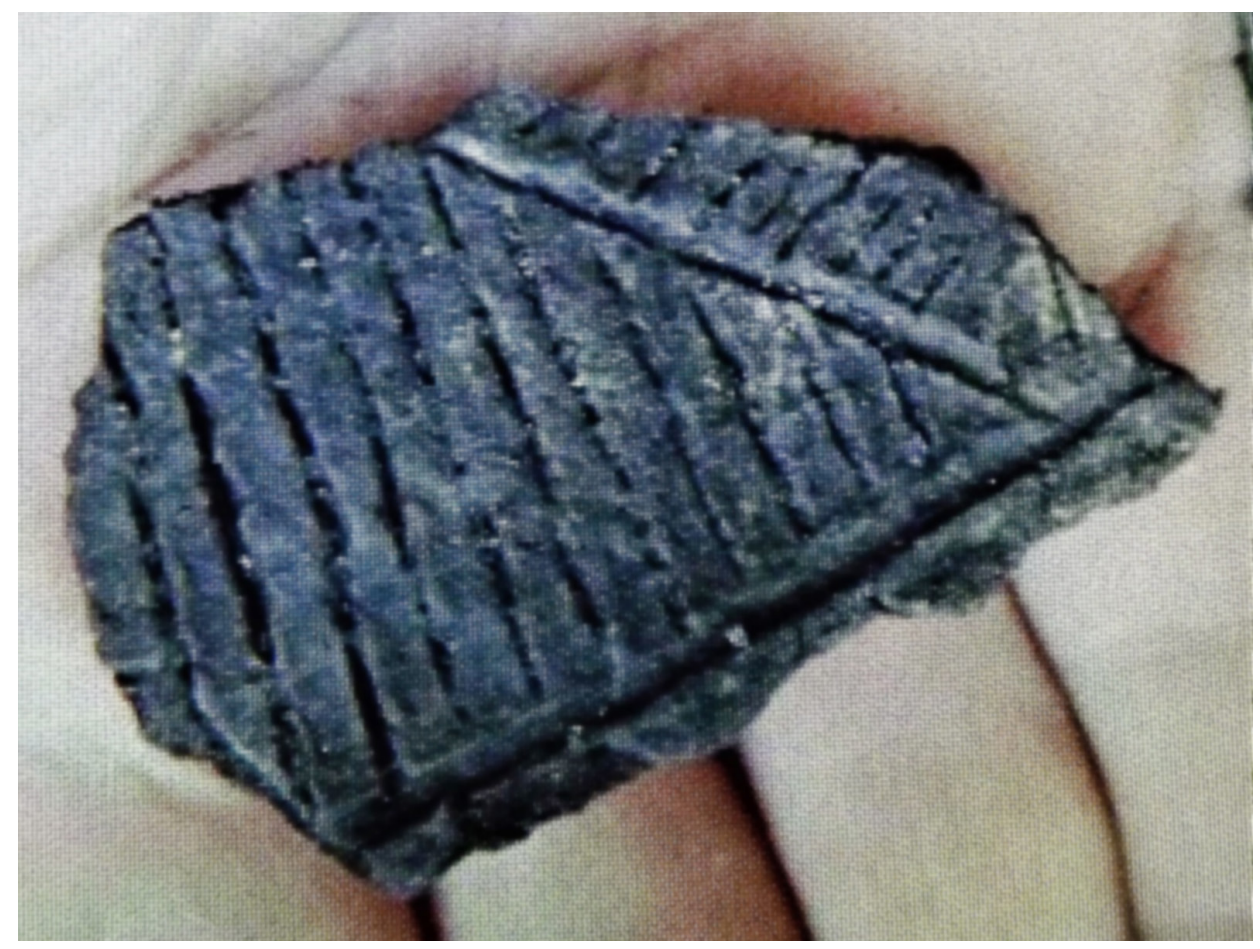

Figure 29. Maydelle Incised sherd from the Chrisner's Ranch site. 
is a grog-tempered lower rim sherd from a La Rue Neck Banded jar. The origin of these sherds-vessels is likely Frankston phase (ca. A.D. 1400-1680) sites in the upper Neches River basin in East Texas.

\section{Frank Simmons/McLeod Farm (39C3-7)}

Frank Watt collected seven ceramic sherds from at least three Caddo vessels at the Frank Simmons/ McLeod Farm site. Six of the seven sherds are from grog-tempered Bullard Brushed vessels, and the other sherd from a Bullard Brushed vessel has bone temper. All of the grog-tempered sherds have either opposed ( $\mathrm{n}=1$ ) or parallel brushing $(\mathrm{n}=5)$ marks (Figure 30a), and the bone-tempered body sherd has opposed brushed-incised marks and lines (Figure 30b).

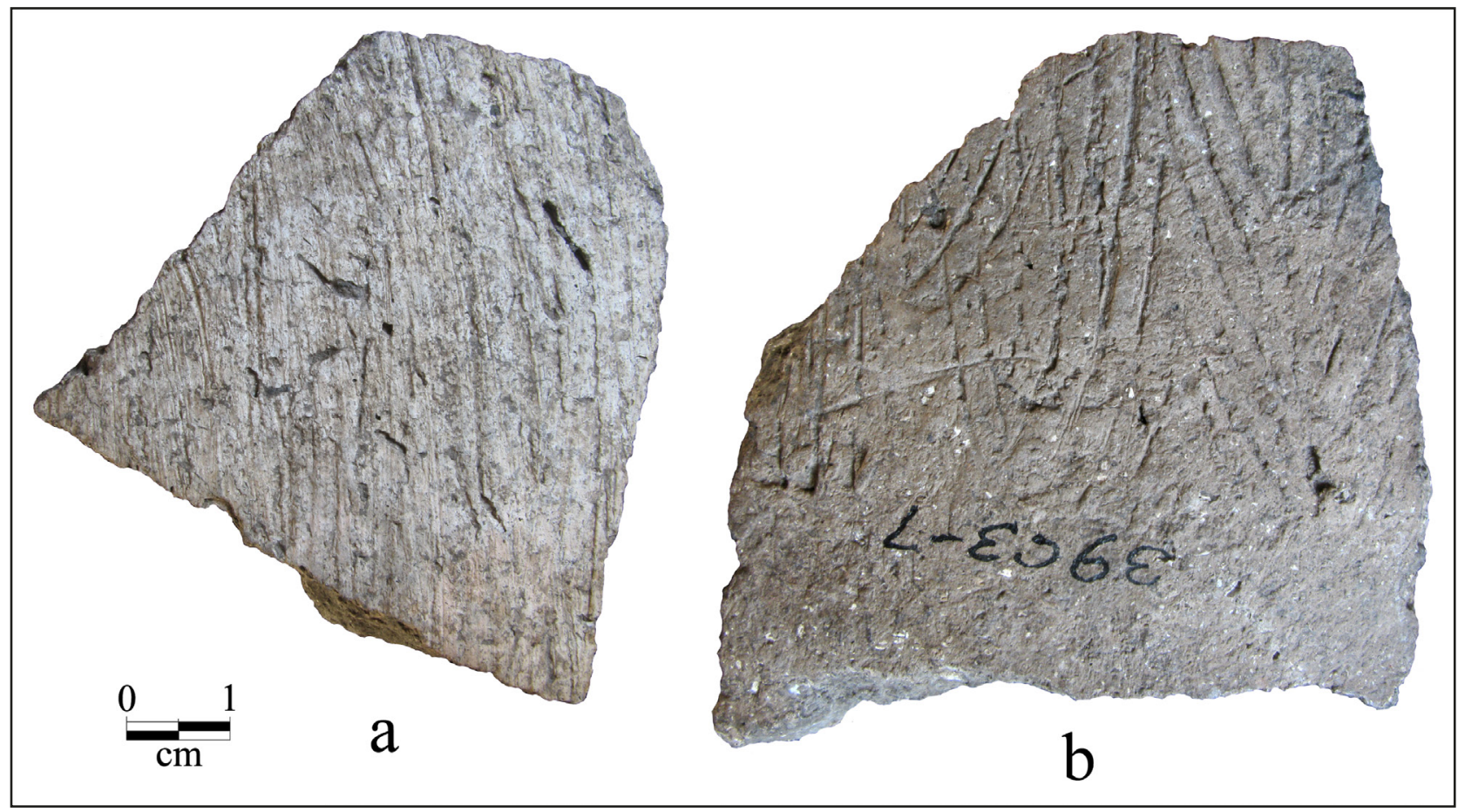

Figure 30. Decorated sherds from the Frank Simmons/McLeod Farm in Coryell County, Texas.

\section{K. H. Aynesworth Collection-Kinsey Farm Spring}

This unrecorded site is in the Leon River basin not far from Gatesville, Texas, and the Fort Hood Military Reservation. The collection has four plain grog-tempered body and base sherds from an ancestral Caddo vessel of uncertain form.

\section{Johnson Hole}

Excavations by Miller and Jelks (1952:197) at the Johnson Hole site on the Leon River at Lake Belton recovered a single Holly Fine Engraved sherd in an Austin phase context. Holly Fine Engraved vessels were manufactured by East Texas Caddo potters between ca. A.D. 900-1200. 


\section{Dimmit County}

\section{$41 D M 134$}

Although this site is in South Texas (see Figures 1-2), in the southwestern part of Dimmit County, it is worth mentioning in this report because the site has a sherd from an ancestral Caddo Maydelle Incised jar (Figure 31). This is the southernmost occurrence of Caddo ceramic vessel sherds in Texas. The rim sherd has a continuous series of incised triangles that are filled with incised lines pitched in opposite directions.

\section{Gillespie County}

\section{$41 G L 321$}

A rim sherd of the post-A.D. 1400 Late Caddo type McKinney Plain has been identified from 41GL321 (Malof and Evans 2016:619 and Figure 289). The sherd has a "polished interior, small exterior pinched knob [appliqued node] and a roughened exterior." McKinney Plain is typically found in post-A.D. 1400 Texarkana phase ancestral Caddo components along the Red River in Bowie County, Texas (see Suhm and Jelks 1962:97 and Plate 49).

\section{Hamilton County}

\section{Jayroe Site (41HM51)}

The ceramic analyses by Gadus (n.d.) of the Jayroe site (41HM51) sherds identified 43 sherds that could be sorted into seven different groups of sherds, from 1 to 12 sherds per group (Table 13). Three of the sherd groups were considered to be part of three different vessels (Vessels No. 1-3) and the four groups of miscellaneous sherds may be part of Vessel No. 1 (sherd groups a and b on Table 13) or from other undefined vessel sherd groups.

Vessels No. 1 and No. 2, as well as miscellaneous sherd groups a, b, and d, have decorative elements, while the sherds from Vessel No. 3 may be from a plain olla-like vessel and miscellaneous sherd group c is a flat base sherd (see Table 13). Each of the sherd groups are from vessels tempered either with grog or grog-bone; Vessels No. 1 and No. 3 have both tempers, as do miscellaneous sherd groups a and c.

Vessel No. 1 is a jar that has a series of horizontal incised lines on the rim (see Gadus n.d.:Figure $1 \mathrm{a}-\mathrm{b})$. It is possible that miscellaneous sherd groups a and $\mathrm{b}$ represent the diagonal brushed body of Vessel No. 1 (see Gadus n.d.:Figure 1c-e), and sherd group c the base (see Gadus n.d.:Figure 1f). These kinds of decorative elements are common features of East Texas Caddo ceramics, especially on utility ware vessels in the Neches-Angelina River basins (see Perttula 2013). Sherds from brushed utility ware vessels, particularly jars, are a distinctive characteristic of both Middle (ca. A.D. 1200-1400), Late (ca. A.D. 1400-1680), and Historic (post-A.D. 1680) Caddo sites in much of East Texas. It also appears to be the case that the relative proportions of brushed utility wares increase through time in those areas where 
Table 13. Jayroe Site Ceramic Sherd Assemblage.

\begin{tabular}{|c|c|c|c|c|}
\hline $\begin{array}{l}\text { Vessel No./ } \\
\text { Sherd Group }\end{array}$ & $\begin{array}{l}\text { No. of } \\
\text { Sherds }\end{array}$ & Description/Temper & Petrography & INAA \\
\hline No. 1 & 11 & $\begin{array}{l}\text { Horizontal incised rim, grog and } \\
\text { grog-bone }\end{array}$ & $\begin{array}{l}\text { EU } 16,97 \\
\text { Group } 2\end{array}$ & $\begin{array}{l}\text { Group A, } \\
\text { Group C }\end{array}$ \\
\hline No. 2 & 8 & $\begin{array}{l}\text { curvilinear appliqued body sherds, } \\
\text { grog }\end{array}$ & $\begin{array}{l}\text { EU 43, } 124, \\
\text { TU 19; Group } 1 \\
\text { and Unidentified }\end{array}$ & $\begin{array}{l}\text { Group B, } \\
\text { Group C }\end{array}$ \\
\hline No. 3 & 12 & $\begin{array}{l}\text { plain olla-like vessel, grog and } \\
\text { grog-bone }\end{array}$ & $\begin{array}{l}\text { EU 57, 131; } \\
\text { Unidentified Group }\end{array}$ & Group B \\
\hline \multicolumn{5}{|c|}{ Miscellaneous Sherds } \\
\hline a. & 8 & $\begin{array}{l}\text { brushed body sherds, grog and } \\
\text { grog-bone }\end{array}$ & $\begin{array}{l}\text { EU } 63, \text { TU } 17 ; \\
\text { Group } 1\end{array}$ & $\begin{array}{l}\text { Group A, } \\
\text { Group B }\end{array}$ \\
\hline b. & 2 & $\begin{array}{l}\text { brushed-incised body sherds, } \\
\text { grog }\end{array}$ & $\begin{array}{l}\text { EU 9; Unidentified } \\
\text { Group }\end{array}$ & Group A \\
\hline c. & 1 & flat base, grog-bone & $\begin{array}{l}\text { TU 17; Unidentified } \\
\text { Group }\end{array}$ & Group A \\
\hline $\mathrm{d}$. & 1 & fingernail punctated rows, grog & - & - \\
\hline
\end{tabular}

brushed vessels were made and used, such that sherds with brushing marks may comprise as much as 90 percent of all the decorated sherds in some post-A.D. 1400 East Texas ceramic assemblages. In the East Texas Caddo ceramic sherd database, only a few ca. A.D. 1200-1430 sites have assemblages with high proportions ( $>60$ percent of the decorated sherd assemblage) of brushed sherds; these occur in the mid-Sabine and Big Cypress Creek drainage basins (see Perttula 2015a:Table 1). Late Caddo ceramic assemblages in East Texas with high proportions of brushed sherds occur in the upper and mid-Neches (Frankston phase sites), Angelina, middle Sabine and Big Cypress (Titus phase sites), and sites (of unknown cultural taxonomy) on tributaries of the Sabine River west of the Toledo Bend Reservoir area (Perttula 2015a:Figure 5). Caddo ceramic assemblages without considerable amounts of brushed sherds occur in the upper Sabine, Sulphur, and Red River basins (Figure 32).

The fact that there is little bone added to the paste of Vessel No. 1 (and associated miscellaneous sherd groups) also suggests that these sherds, if made by an East Texas Caddo potter, were made by a potter in only certain parts of East Texas. The use of burned animal bone for the temper of ceramic vessels is a distinctive characteristic of certain East Texas Caddo ceramic sherd assemblages, and most ceramic assemblages in the region have some bone-tempered sherds (see Perttula 2015a:Table 1). However, sherd assemblages with high proportions ( $>40$ percent of the sherd assemblage) of bone temper are concentrated in only a few locales across East Texas, most notably in the Toledo Bend Reservoir area along the middle Sabine River and in sites in the Angelina River basin (see Figure 9). Bone-tempered 


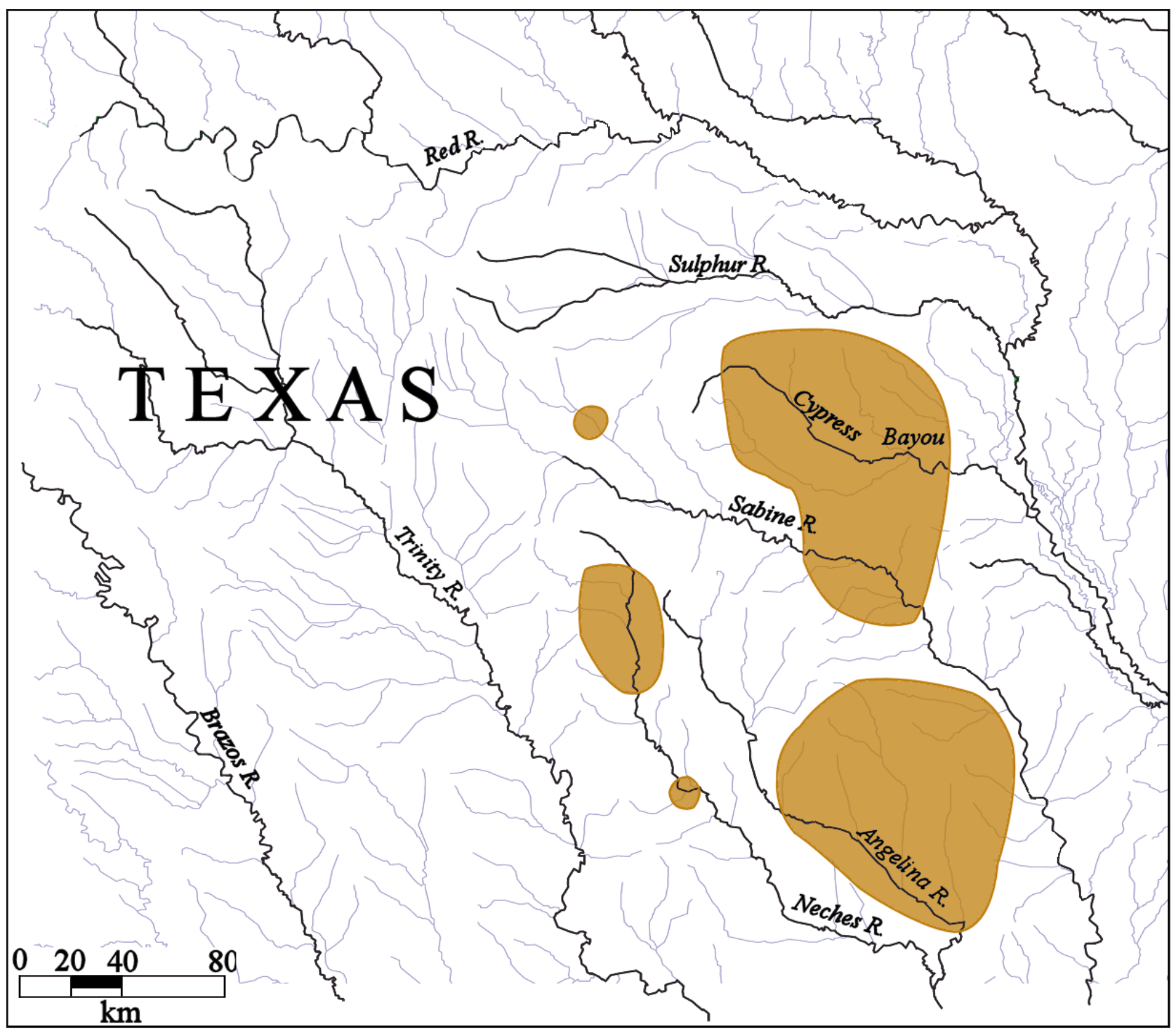

Figure 32. The distribution of areas in East Texas with high proportions of brushed Caddo ceramic vessels and sherds.

sherds are not a notable feature of Caddo ceramic assemblages in the Neches, upper Sabine, Big Cypress, Sulphur, or Red River basins.

Pre-A.D. 1400/1450 Caddo sites with a high proportion of bone temper are found only in a few areas in the middle Sabine River basin. Late Caddo (ca. A.D. 1400-1680) sites and assemblages with high proportions of bone temper are found in one site in the Trinity River basin, and in several sites in the mid-Sabine and Angelina River basins. In fact, these sites are part of a previously identified Late Caddo bone-tempered and brushed ceramic tradition (see Figure 9; see also Perttula 2011:Figure 6-71). Vessel No. 1 at the Jayroe site is apparently from a Late Caddo period grog-tempered and brushed ceramic tradition apparently centered either in the upper Neches (in Frankston phase sites) and/or upper Sabine River (in Titus phase sites) basins, although brushed pottery is much less common in upper Sabine River Titus phase sites than it is in upper Neches River basin Caddo communities. 
Vessel No. 2 from the Jayroe site is an everted rim and grog-tempered jar with curvilinear appliqued ridges (see Gadus n.d.:Figure 2a-b). A fingernail punctated rim (miscellaneous sherd group d) may also be part of Vessel No. 2. The decorative elements are clearly consistent with the Harleton Appliqued type (see Suhm and Jelks 1962:Plate 33). This is a common utility ware in Late Caddo Titus phase (ca. A.D. 1430-1680) sites in the upper Sabine and Big Cypress drainage basins in East Texas (see Perttula 2013); Caddo vessels in these areas were typically grog-tempered.

Vessel 3 includes sherds from the rim and neck of an olla-like vessel (see Table 13). The sherds included with this vessel by Gadus (n.d.:Figure 2d-e) are grog- or grog-bone-tempered. As Kenmotsu and Boyd (2012:12) note, ollas "with somewhat constricted mouth" are one of the four known Toyah phase vessel types, but they are bone-tempered. Ollas were also made by East Texas Caddo potters (see Suhm and Jelks 1962:Plates 3j, 14b-d, 37e, 38n, 41g, I, 59k, 65k-1, and 78k), in Late Caddo Titus phase, McCurtain phase, and post-A.D. 1680 Historic Caddo period contexts. These ollas usually have plain rims (but see Suhm and Jelks 1962:Plate 59k), but have decorated bodies, either with engraved or brushed decorative elements.

The petrographic analysis of 11 sherds from the Jayroe site (Barkwill-Love n.d.) led to the identification of two different petrographic groups-Group 1 with one sherd from Vessel No. 2, and two sherds from miscellaneous sherd group b, thought to be part of Vessel No. 1-and Group 2 with two sherds from Vessel No. 1 (see Table 13). Most of the sherds $(n=6)$ were not assigned to a petrographic group; these include two sherds from Vessel No. 2, two sherds from Vessel No. 3, and single sherds from miscellaneous sherd groups a and c; the latter two sherd groups are thought by Gadus (n.d.) to be part of Vessel No. 1. As detected in the petrographic analysis, the ubiquity of grog as a temper in the manufacture of vessels used at the Jayroe site, and the almost complete absence of bone temper, is particularly notable with respect to considerations of vessel sherd provenance.

All of the sherds analyzed by petrography have grog temper, ranging from 1.5 to 10.2 percent of the point counts (see Barkwill-Love n.d.). The highest proportion of grog temper is in the two Vessel No. 1 sherds and the base sherd comprising miscellaneous sherd group c.

Only four of the analyzed sherds from the Jayroe site have bone in the paste. Of these, only the one sherd in sherd miscellaneous group a (see Table 13) has bone (a very low 0.4 percent of the point counts) inclusions added as temper. The other three sherds - from Vessel No. 1 and miscellaneous sherd group $\mathrm{c}$-have bone in pieces of grog, indicating that they came from ground-up sherds from another vessel that had bone temper.

It is disconcerting that sherds sorted by Gadus (n.d.) into vessel groups fall into more than one petrographic group. In the case of Vessel No. 1, two sherds are in Petrographic Group 2, but miscellaneous sherd groups a-c, thought to also be part of Vessel No. 1, have been grouped by BarkwillLove into either Petrographic Group 1 or an unidentified petrographic group. Similarly, the three sherds from Vessel No. 2 analyzed by petrography have been assigned to either Group 1 or an unidentified petrographic group. These results suggest that the vessel sherd sorting of Vessels No. 1 -and the miscellaneous sherd groups thought to also be part of Vessel No. 1-and No. 2 may not be of particular utility, and/or that the petrographic groupings based on sand size, the proportion of angular sandy grains, and paste coloration - instead of the presence of grog, bone, hematite, and mica in the point counts - are likely not critical to petrographic group identifications. 
The instrumental neutron activation analysis (INAA) of split samples of the 11 sherds analyzed by petrography from the Jayroe site was completed by Ferguson and Glascock (n.d.). The chemical constituents of the 11 sherds led to the identification of three INAA groups: Groups A, B. and C (see Table 13).

In comparing the INAA results from the Jayroe site to the 15 previously defined Central Texas chemical groups (see Creel et al. 2013:47-49), Group A sherds (a Vessel No. 1 sherd and sherds from miscellaneous sherd groups a-c) from the Jayroe site are distinct from all the reference groups except Group 15, although Ferguson and Glascock (n.d.) note that these "samples differentiate from Group 15 in numerous other Bivariate plots." Creel et al. (2013:53 and Figure 17) have commented that other Group 15 sherds are from sites along the Colorado River in the Edwards Plateau, well to the south and west of the Jayroe site.

The Group B sherds from Jayroe (one punctated rim sherd thought to be from Vessel No. 2, two sherds from Vessel No. 3, and one brushed sherd in miscellaneous sherd group a, thought to be from Vessel No. 1) are chemically most similar to Central Texas chemical groups 10 and 11 (Ferguson and Glascock n.d.), "with a slightly stronger match with Group 11." According to Creel et al. (2013:Figures 20 and 24), the Group 10 and 11 sherds are primarily from sites in the Edwards Plateau and the Gulf Coastal Plain well south and west of the Jayroe site, and include many Leon Plain, Goliad Plain (see Hester 1989; Mounger 1959:163-181), untyped bone-tempered plain, and untyped sandy paste plain sherds. One sherd from Group 10C is a Boothe Brushed sherd from a site in the Colorado River basin south of the Jayroe site (Creel et al. 2013:61 and Figure 23). Creel et al. (2013:60) also comment that a number of Caddo pottery sherd samples in the Central Texas INAA database "have high probabilities of membership in Group 10," but significantly they also note that there is a "considerable overlap between Group 10 and most of the previously analyzed Caddo pottery samples from Caddo sites in East Texas." Furthermore, even if these sherds have a high probability of membership in Group 10 "does not necessarily imply production of Caddo vessels in Central Texas."

The INAA Group C sherds from the Jayroe site are from Vessels No. 1 and No. 2; inexplicably, other sherds from these two vessels have been assigned to other INAA chemical groups: Group A for one sherd from Vessel No. 1 and Group B for the punctated rim thought to be a part of Vessel No. 2. Ferguson and Glascock (n.d.) note that the Group C sherds are distinct from "all of the Central Texas Reference Groups except for Group 8, but many other plots show a clear separation from Group 8." Creel et al. (2013:59 and Figure 19) suggest that Group 8 sherds have a Balcones Escarpment production zone, well west of the Jayroe site.

Stylistic, technological, petrographic, and instrumental neutron activation analysis (INAA) has been completed of a small assemblage of ceramic sherds $(n=43)$ from as few as three separate vessels (Vessels No. 1-3) from the Jayroe site. The ceramic sherds are associated with a Late Prehistoric Toyah phase (ca. A.D. 1250-1700) occupation.

The decorative elements on the sherds from Vessels No. 1 and No. 2 are consistent with those on Caddo utility ware vessels from the Neches, Sabine, and Big Cypress drainage basins in East Texas in Late Caddo (ca. A.D. 1400-1680) Titus phase and Frankston phase contexts. Vessel No. 3 at the Jayroe site is the rim and neck of an olla-like vessel. Ollas were also made by Titus phase Caddo groups in the Sabine and Big Cypress basins. Additionally, Caddo ceramic vessels made in the upper parts of these three drainage basins are primarily grog-tempered, with little bone being used in vessel manufacture.

The Jayroe site ceramic sherds are from grog-tempered vessels, with very limited use of burned bone as a temper (and in three of the four sherds with bone, the bone occurred within pieces of grog), and 
thus they share technological and manufacturing practices with East Texas Caddo ceramics rather than with the primarily bone-tempered (and plain) ceramic vessels thought to have been made locally by East Central and Central Texas Toyah phase groups (e.g., Creel et al. 2013).

In the case of the INAA of the Jayroe sherds, comparison of the sherds to the Central Texas database suggests the sherds from the site are associated to Central Texas chemical groups 8, 10/11, and 15 .

Except for the Caddo sherds in chemical group 10 that chemically overlap with sherds more likely to be from vessels made in Central Texas, the sherds included in these chemical groups have Edwards Plateau and Gulf Coastal Plain production locales well to the south and west of the Jayroe site. These sherds are primarily from bone-tempered and sandy paste vessels that are stylistically and technologically distinct from the Jayroe site sherds.

Tomka (n.d.) notes that the Jayroe site sherds were also compared to the East Texas Caddo INAA database. The Jayroe site sherds were found to be compositionally very similar to the sherds in the existing Caddo INAA database, and Vessels No. 1 (incised-brushed) and No. 2 (Harleton Appliqued) were matched with East Texas core chemical groups 4/5 and 9 (Tomka n.d.; see Perttula 2013:Figure 9). The incised-brushed sherds from Vessel No. 1 are matched with chemical group 9, which include sherds from the Neches and Angelina River basins; utility ware vessels with the kind of decorative elements noted on Vessel No. 1 are common in those parts of East Texas. One of the Vessel No. 2 sherds from a Harleton Appliqued jar, and both sherds from the olla-like Vessel No. 3, at the Jayroe site match with the East Texas Caddo chemical group 5. This chemical group includes sites in the upper Sabine and Cypress drainage basins, an area densely occupied by Late Caddo Titus phase Caddo groups.

Based on the preponderance of the evidence gathered in the detailed analysis of the aboriginal sherds from the Jayroe site, it appears most likely that they are from grog-tempered vessels manufactured by Caddo potters living in East Texas communities. The decorative elements on Vessel No. 1 and No. 2 are consistent with utility ware vessels made in post-A.D. 1400 Frankston and Titus phase sites in the Neches, Sabine, and Big Cypress drainage basins (particularly the upper parts of these basins, where not much bone-tempered Caddo pottery is present), and the INAA comparisons with the existing Caddo INAA database point to these same areas as the manufacturing locales of the vessels that were eventually used by non-Caddo groups that lived at the Jayroe site.

\section{Hays County}

\section{$41 H Y 14$}

Ceramic sherds have been recovered from this site on the Blanco River, including a plain shelltempered sherd of possible Caddo manufacture in the TARL collections. Shell-tempered Caddo pottery is most commonly found on post-A.D. 1300 sites in McCurtain phase sites in the middle Red River basin, as well as in post-A.D. 1680 sites in several parts of the Red River basin in East Texas (see Perttula et al. 2012; Selden et al. 2014).

\section{Barton (North) 41HY202-A}

Excavations at the Barton site (North) near the headwaters of Onion Creek in the Colorado River basin recovered 18 small sherds from one vessel (a flat-bottomed jar) in the Toyah component at the site (Ricklis and Collins 1994:225). This vessel is tempered with grog (Reese-Taylor et al. 1994:561) and has parallel (or vertical) brushing marks on the exterior surface (Ricklis and Collins 1994:Figure 118a). Ricklis and Collins (1994:228) cautiously suggest that this vessel "may have had a Caddoan [sic] 
origin" after conducting macroscopic and microscopic analyses of the sherds from this site. Reese-Taylor et al. (1994:566) conclude that "the grog-tempered, brushed vessel from 41HY202-A' would not be out of place in a Caddoan [sic] assemblage, and this vessel...likely represents transport/importation from East Texas." Reese-Taylor et al. (1994:566) go on to conclude that "some, if not much, of the Caddolike pottery found at Toyah interval sites in Central Texas represent westward transport of actual Caddo vessels... and may represent some sort of exchange rather than the actual presence of Caddo people."

One ancestral Caddo sherd from 41HY202-A in the TARL collection is a grog-tempered body sherd with parallel brushing marks from the one recovered vessel section described above. This sherd is from an East Texas vessel that was made by a Caddo potter sometime after ca. A.D. 1200, and after the beginning of the Toyah phase in Central Texas.

\section{Mustang Branch (41HY209-T)}

The Mustang Branch site on Onion Creek has a Toyah phase component that has been radiocarbondated to between A.D. 1453-1654 (Ricklis and Collins 1994:267 and Table 42). Excavations at the site recovered 480 ceramic vessel sherds divided into five Groups (Ricklis and Collins 1994:262-264). Two of the groups are sherds from ancestral Caddo vessels, and a third (Group 4) may well also be an ancestral Caddo ceramic vessel.

The first group is Group 3 ( $\mathrm{n}=5$ sherds) from a grog-tempered Poynor Engraved carinated bowl (Ricklis and Collins 1974:Figure 142a-b). The engraved decorative elements on the rim panel consist of nested ovals and diagonal cross-hatched ladders, namely Var. F of Poynor Engraved, a regional variety of Poynor Engraved in the upper Neches River basin in East Texas (Perttula 2011:Figure 6-65). This particular variety of Poynor Engraved was most commonly manufactured by Caddo potters between ca. A.D. 1400-1480, but continued to be made from ca. A.D. 1480-1560 (Perttula 2011:Table 6-37).

The second group of sherds from ancestral Caddo vessels at the Mustang Branch site is Group 5 ( $\mathrm{n}=2$ sherds). These are from a grog-tempered brushed vessel (Ricklis and Collins 1994:263), likely a Bullard Brushed vessel.

PIXE analysis of the paste of the Group 3 and 5 sherds indicates that they can be segregated from what is considered locally-made ceramic vessels at the Mustang Branch site (Ricklis and Collins 1994:266).

Group 4 had nine sherds from a vessel with a plain rim, other than a horizontal row of tool punctations at the rim-body juncture, and vertical brushing marks on the vessel body; it is bone-tempered (Ricklis and Collins 1994:Figure 142c-d). It has been identified as a Boothe Brushed vessel, even though bone-tempered Bullard Brushed vessels are known from the Caddo area (Suhm and Jelks 1962:21 and Plate 11). PIXE analysis of the Group 4 sherds, and a sherd from the A. C. Saunders mound site (41AN19) in the upper Neches River basin suggests that this brushed-punctated vessel may also be of ancestral Caddo origin (Ricklis and Collins 1994:266).

Three sherds from this site in the TARL collection are from ancestral Caddo vessels, two from vessels tempered with grog and the other from a vessel tempered with grog and bone. One grog-tempered body sherd has parallel brushing marks (INAA, UT00101, Group 5 in Ricklis and Collins [1994]), while the other is a body sherd (INAA, UT00108) with an unidentified engraved element, probably from the postA.D. 1400 Poynor Engraved vessel (Group 3). The grog-bone-tempered body sherd has a row of fingernail punctations (INAA, UT00099), and this may be from sherd Group 2 (Ricklis and Collins 1994:262-263 and Figure 141a-b). Reese et al. (1994:566) suggest this vessel was locally produced in Central Texas. 


\section{Hill County}

\section{Kyle Rockshelter (41HI1)}

Ancestral Caddo ceramic vessel sherds at the Kyle site date to Early Caddo period times (ca. A.D. 900-1200). Almost all of them may all be from one grog-tempered Hickory Engraved bottle (INAA, UT00008) with at least three horizontal engraved lines on the upper vessel body and seven horizontal engraved lines on the upper bottle neck (Jelks 1962:Figure 24). The bottle neck is $7.6 \mathrm{~mm}$ thick, has been burnished on the exterior surface, and the neck has a $9.0 \mathrm{~cm}$ orifice diameter. The vessel has a red slip on both interior and exterior surfaces, suggesting the red slip was poured into the open bottle to coat the interior surface before it was fired.

There are four plain grog-tempered body sherds in the Kyle Rockshelter assemblage from another vessel, and none have a red slip. One of the sherds is burnished on the exterior surface, and may be from a bowl or carinated bowl, as these often have this sort of interior-exterior surface treatment.

\section{Blum Rockshelter (41HI8)}

Excavations by Jelks (1953) at the Blum Rockshelter, overlooking the Nolans River in the Brazos River basin and the Lake Whitney flood pool, recovered ancestral Caddo sherds (Table 14) from Stratum 2; these sherds are in TARL collections. Archaeological deposits in Stratum 2 are from a Toyah phase occupation with Perdiz arrow points (Jelks 1953:205). The Caddo sherds are from several vessels that likely were manufactured after ca. A.D. 1400/1480 by Caddo peoples in the upper Neches River basin in East Texas.

Table 14. Caddo ceramic wares at the Blum Rockshelter (41HI8).

Ware $\quad$ Temper Categories

\begin{tabular}{lllll} 
& Grog & Grog-Bone & Bone & N \\
\hline Plain ware & 29 & 12 & 1 & 42 \\
Utility ware & 16 & 4 & - & 20 \\
Fine ware & 5 & - & - & 5 \\
\hline Totals & 50 & 16 & 1 & 67 \\
\hline
\end{tabular}

About 98.5 percent of these sherds are from vessels tempered with grog, either as the sole temper (74.6 percent), or in conjunction with burned bone (23.9 percent). Only one sherd (1.5 percent) is tempered solely with burned bone (see Table 14). There are plain grog-tempered rim and body sherds from at least one vessel that have $20 \mathrm{~cm}, 22 \mathrm{~cm}$, and $30 \mathrm{~cm}$ orifice diameters; one of these vessels - with 17 conjoined sherds - is Vessel 2 identified by Jelks (1953:205). 
Eighty percent of the decorated sherds from the Blum Rockshelter are from utility ware vessels, and most of these have rows of fingernail punctations (Table 15); this is Vessel 4 (Jelks 1953:205). The incised and incised-punctated sherds are from two different Maydelle Incised vessels; those with incisedpunctated elements (Figure 33c) are from Vessel 3 (Jelks 1953:205).

Table 15. Decorative methods and elements in the utility ware and fine ware sherds from the Blum Rockshelter site (41HI8).

\begin{tabular}{llll}
\hline Decorative method-elements & Rim & Body & $\mathrm{N}$ \\
\hline
\end{tabular}

Utility Ware

Incised

diagonal opposed incised lines (Maydelle Incised)

1

1

Incised-Punctated

diagonal incised panel with tool punctations

diagonal opposed incised lines with tool punctated panel (Maydelle Incised)

vertical incised panels filled with tool punctations

(Maydelle Incised)

\section{Punctated}

fingernail punctated row/rows

$\begin{array}{lll}- & 10 & 10\end{array}$

single fingernail punctation

opposed tool punctated rows

$\begin{array}{ll}- & 5\end{array}$

Fine Ware

\section{Engraved}

horizontal engraved line

horizontal engraved lines and triangle el. filled with curvilinear or diagonal engraved lines (Poynor Engraved)

horizontal and diagonal engraved lines

horizontal-diagonal engraved lines with cross-hatched engraved triangle el.

open and vertical hatched triangle elements

$\begin{array}{lll}- & 1 & 1 \\ - & 1 & 1 \\ 1 & - & 1\end{array}$

Totals

The fine ware sherds from the Blum Rockshelter are from at least two vessels. The first is a rim sherd (Vessel 1) from a Poynor Engraved, var. unspecified vessel (see Figure 33a), perhaps var. Cook or var. Lang (Perttula 2011:Figure 6-64), while the other is an engraved bowl (Vessel 5) with open or vertical hatched triangle elements on the upper body (see Figure 33b). Similar triangular motifs have been noted on both post-A.D. 1400 Poynor Engraved and Hume Engraved vessels in upper Neches River Caddo ceramic assemblages. 


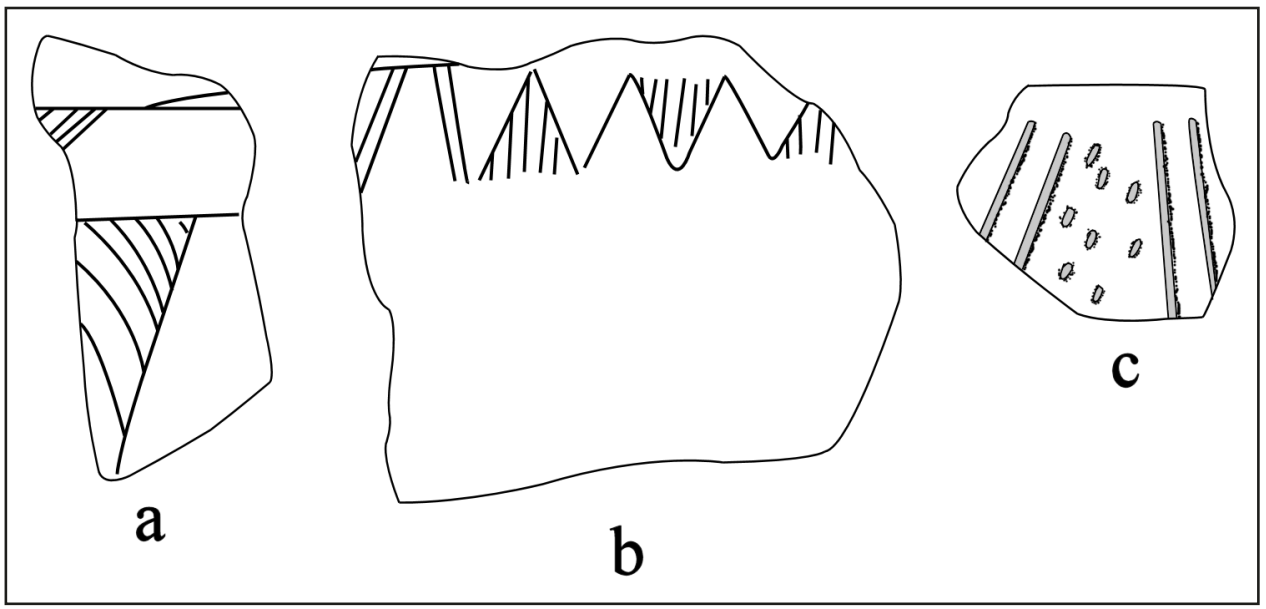

Figure 33. Decorative elements on selected sherds from the Blum Rockshelter site.

\section{Stansbury (41HI9)}

Stephenson's work at the Stansbury site in 1947 and 1950 recovered only 18 ceramic sherds from this late $18^{\text {th }}$ century Wichita habitation site. These are from an ancestral Caddo Womack Engraved bowl with large hatched pendant triangle elements (Stephenson 1970:76 and Plate 2d), three different Patton Engraved vessels, and one sherd from a bowl or carinated bowl with an interior slip, and a "small, curved, engraved line on the exterior" (Stephenson 1970:78).

One bone-tempered body sherd from the Stansbury site (41HI9) in the TARL collection is from an ancestral Caddo vessel with opposed engraved lines; the type is uncertain. There is also an exterior burnished and grog-tempered elbow pipe with a distal knob in the collection that may have been made by a Caddo group, as such forms are common after ca. A.D. 1300 on East Texas Caddo sites. The elbow pipe bowl is $8.8 \mathrm{~mm}$ in thickness. Another pipe of very similar form, tempered with grog and bone, has been found at the late $18^{\text {th }}$ century Walton site (41ML65) on the Brazos River (Story 1985:Figure 4a-a'), and several examples of similar elbow pipes (of clay or stone) are illustrated by Stephenson (1970:82 and Plate 3) from River Basin Surveys work at the Stansbury site.

\section{Bear Creek Shelter (41HI17)}

One of the three ceramic vessel sherds recovered by Lynott (1978:43, 1980:Table 8) at Bear Creek Shelter on Aquilla Creek is a plain grog-tempered rim sherd from an ancestral Caddo vessel in a Toyah phase component. The other two sherds have a sandy paste and limestone temper, and were likely manufactured locally by aboriginal peoples sometime during the Austin phase, which Lynott (1980:218) dates from ca. A.D. 500-600 to A.D. 1200.

\section{Lavender (41HI30)}

The ancestral Caddo ceramic vessel sherds from the Lavender site, a rock shelter, include two Weches Fingernail Impressed body sherds (Figure 34), probably var. Weches (see Stokes and Woodring 1981), and eight plain sherds. The Weches Fingernail Impressed sherds are indicative of use from ca. A.D. 900-1200. 


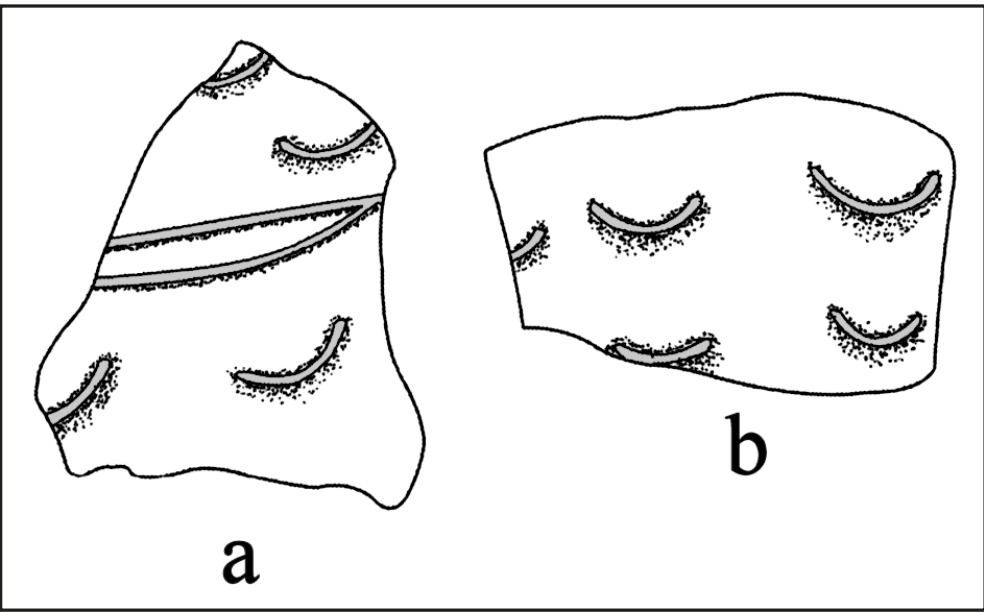

Figure 34. Weches Fingernail Impressed sherds from the Lavender site (41HI30) in Hill County, Texas.

\section{Sour Mash (41HI34)}

The ancestral Caddo ceramic vessel sherds from 41HI34 in the TARL collections include only one plain grog-tempered rim sherd and 46 sherds from utility ware or fine ware vessels (Table 16). About 62 percent of the sherds are from grog-tempered vessels; another 23.4 percent are from bone-tempered vessels (all utility ware); and 14.9 percent are from grog-bone-tempered vessels.

Table 16. Ceramic wares at the Sour Mash site (41HI34).

Ware

Temper Categories

\begin{tabular}{lllll} 
& Grog & Grog-bone & Bone & N \\
\hline Plain ware & 1 & - & - & 1 \\
Utility ware & 23 & 6 & 11 & 40 \\
Fine ware & 5 & 1 & - & 6 \\
\hline Totals & 29 & 7 & 11 & 47
\end{tabular}

The decorated sherds from the Sour Mash site (41HI34) are dominated by sherds from utility ware vessels (Table 17), as they comprise about 87 percent of the decorated sherd sample (see Table 16). The principal decorative elements in the utility wares are cross-hatched and diagonal incised lines from Dunkin Incised vessels, an Early Caddo period ceramic type; sherds with incised decorative elements comprise 41.3 percent of the decorated sherds from the site. One body sherd is from a contemporaneous Crockett Curvilinear Incised vessel (Figure 35b). Also in the assemblage are two Weches Fingernail Impressed, var. Weches body sherds (Figure 35a); these vessels were also made during the Early Caddo period by Caddo potters. 
Table 17. Decorative methods and elements in the utility ware and fine ware sherds from the Sour Mash site (41HI34).

\begin{tabular}{llll}
\hline Decorative method and elements & Rim & Body & $\mathrm{N}$ \\
\hline
\end{tabular}

Utility Ware

Brushed

parallel brushed marks

Brushed-Incised

horizontal brushed-overlying diagonal incised line

parallel brushed-incised marks and lines

parallel brushed and overlying parallel incised lines

$\begin{array}{lll} & & \\ 1 & - & 1 \\ - & 2 & 2 \\ - & 1 & 1\end{array}$

\section{Incised}

cross-hatched incised lines (Dunkin Incised)

diagonal incised lines (Dunkin Incised)

opposed incised lines

closely-spaced parallel incised lines

parallel incised lines

straight incised lines

triangular incised el. filled with curvilinear incised lines

(Crockett Curvilinear Incised)

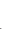

Incised-Punctated

parallel incised lines and circular punctated row parallel incised lines and adjacent fingernail punctated row (Weches Fingernail Impressed)

straight incised line and tool punctated zone

\begin{tabular}{lll} 
& & \\
- & 3 & 3 \\
- & - & 3 \\
- & 1 & 1 \\
- & 1 & 1 \\
- & 8 & 8 \\
- & 2 & 2 \\
\hline
\end{tabular}

\section{Punctated}

fingernail punctated rows

linear punctated rows

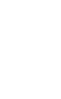

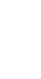

$-$

2

Fine Ware

\section{Engraved}

curvilinear engraved line* opposed engraved lines vertical engraved lines

vertical and diagonal engraved lines*

\section{Engraved-Punctated}

horizontal and diagonal engraved lines-excised punctations overlying one diagonal line

Engraved-Red-slipped

curvilinear engraved line-ext. red-slipped

$\begin{array}{lll}- & 1 & 1 \\ - & 1 & 1 \\ 1 & - & 1 \\ - & 1 & 1 \\ - & & 1 \\ & 1 & \end{array}$

Totals

\begin{tabular}{|c|c|c|}
\hline - & 1 & 1 \\
\hline 5 & 41 & 46 \\
\hline
\end{tabular}

*Bottle sherd 


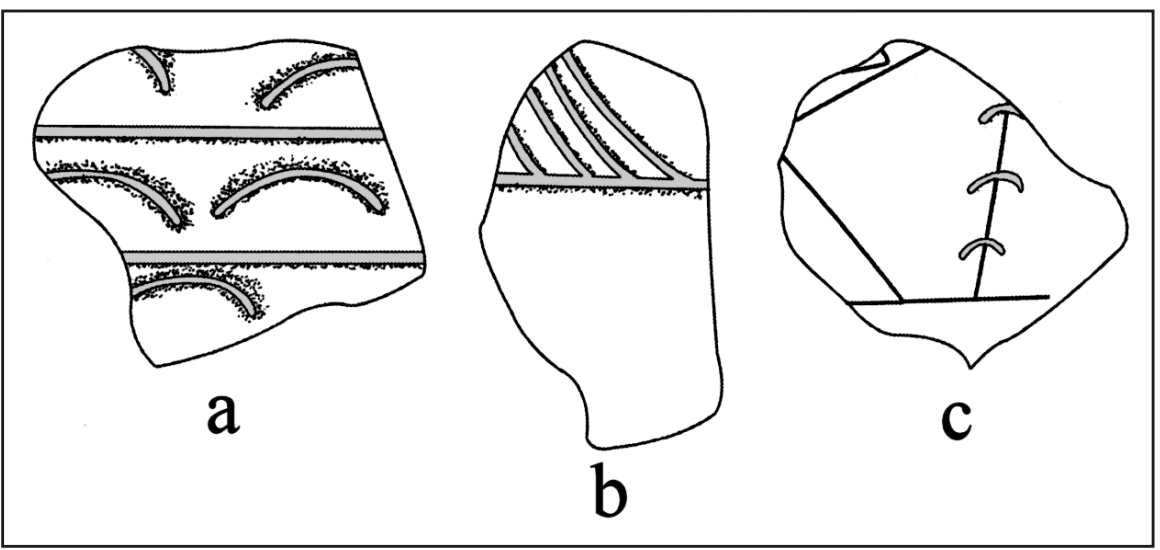

Figure 35. Selected decorative elements on utility ware and fine ware sherds from the Sour Mash site (41HI34).

Brushed and brushed-incised sherds are relatively common in the ceramic assemblage, accounting for 17.4 percent of the decorated sherds (see Table 17). The occurrence of brushed pottery at the site suggests that there was also a post-A.D. 1200 occupation there, because ancestral Caddo potters in East Texas generally began to make vessels with brushed and brushed-incised marks and lines after ca. A.D. 1200, becoming even more common in ceramic assemblages in the region after ca. A.D. 1400.

The fine ware sherds from the Sour Mash site include sherds with engraved $(n=4)$, engravedpunctated ( $n=1$, see Figure 35c), and engraved-red-slipped $(n=1)$ decorative methods. Two of the sherds - with vertical and vertical-diagonal engraved lines - are likely from Early Caddo period Holly Fine Engraved vessels.

\section{Collins (41HI50)}

Archaeological work at the Collins site at Lake Whitney recovered an incised Caddo sherd of uncertain type that is in the TARL collections and was analyzed by INAA (see Creel et al. 2013).

\section{Pictograph Shelter (41HI53)}

Archaeological investigations at this shelter in the Brazos River valley at Lake Whitney by Stephenson (1970:Plate 18 and Table 5) recovered 15 sherds from six different ancestral Caddo vessels. These include eight sherds from a long-necked bottle with an exterior red slip; three plain sherds from a grog-tempered bowl; one sherd from a grog-tempered vessel with a slipped exterior surface; a single grog-tempered sherd with opposed engraved lines; one plain grog-tempered sherd; and a single large sherd with an indeterminate temper (Stephenson 1970:129-130). The sherds were found in Stratum IIb, IIIa, and IIIb, and may be from use of the shelter both before and after ca. A.D. 1200 given the frequency of both Perdiz, Scallorn, and Alba arrow points in these strata.

\section{Buzzard Shelter or Cave (41HI54)}

According to Stephenson (1970:Table 8), 39 ceramic sherds were recovered in Strata I, II, and III in the River Basin Survey excavations of Buzzard Cave in the Brazos River valley at Lake Whitney. These sherds are from two Holly Fine Engraved vessels and a punctated jar (Stephenson 1970:Plate 23), and other sherds have fingernail punctations or "angular engraved lines." According to Stephenson 
(1970:171), the sherds from Buzzard Shelter "are all of pottery vessels of the Caddoan [sic] area of east Texas, and those that are identifiable are of types associated with the Alto Focus [now phase]..." They suggest use of the shelter between ca. A.D. 900-1200.

Sherds from at least eight different vessels were recovered in post-River Basin Survey excavations at Buzzard Cave in the Lake Whitney project area on the Brazos River (Long 1961:226-228 and Figure 2). Two bone-tempered Leon Plain vessels were represented by 31 sherds, and there were seven sherds from three likely Holly Fine Engraved vessels. Another vessel ( $n=4$ sherds) had a sandy paste and may be from a Goose Creek Plain, var. unspecified jar. Finally, there were two sherds at Buzzard Cave from two different Dunkin Incised or Weches Fingernail Impressed vessels. Taken together, the ancestral Caddo ceramics at Buzzard Cave are from vessels likely manufactured between ca. A.D. 900-1200 in an East Texas production locale.

\section{Sheep Shelter (41HI55)}

The Sheep Shelter is in bluffs above a tributary of the Nolans River, about 3 miles south of the Blum Rockshelter (Stephenson 1970:187). The River Basin Survey work at the site recovered 39 ceramic vessel sherds from seven different vessels. They are from two Maydelle Incised jars, a plain grog-bonetempered bottle sherd, one grog-tempered body sherd with brushing marks, likely Bullard Brushed, a bone-tempered sherd with "finely incised, cross-hatched decoration on the exterior," and nine sherds from a plain carinated bowl (Stephenson 1970:199-201 and Plate 33). The last vessel is represented by 19 sherds from a red-slipped bottle that Stephenson (1970:199) classified as Maxey Noded Redware, even though the sherds have no appliqued nodes, but instead are decorated with a band of engraved crosshatched lines below the neck. I am more inclined to consider these sherds as likely being from a Late Caddo period, Frankston phase Hume Engraved bottle. Such an identification would be consistent with the Maydelle Incised and Bullard Brushed sherds present in the assemblage.

\section{McDonald (41HI105)}

The TARL collections from the McDonald site at Aquilla Lake includes 62 ceramic sherds from several vessels and another 70 sherds from the incised Vessel 1 section in Area B (Brown et al. 1987). Brown et al. (1987:38-104) indicate that 127 ceramic vessel sherds had been recovered at the site in both Southern Methodist University and University of Texas investigations, primarily from Area B. Brown et al. (1987:38-105) estimate that the sherds represent between six and 15 different vessels.

INAA has been performed on four sherds (UT00019-22, see Creel et al. 2013); two others had both INAA and petrographic investigations (Perttula et al. 2003:11-13). Not including the Vessel 1 section, more than 80 percent of the ceramic vessel sherds from the site are from vessels tempered solely with grog or fired clay (Table 18). Another 16.1 percent of the sherds are from vessels tempered with both grog and bone, and 3.2 percent are from vessels tempered solely with crushed and burned bone. 
Table 18. Caddo ceramic vessel sherds from the McDonald site.

\begin{tabular}{lllll}
\hline Ware & grog-tempered & grog-bone-tempered & $\begin{array}{l}\text { bone- } \\
\text { tempered }\end{array}$ \\
\hline Plain & 23 & $7 *$ & 2 & 32 \\
Utility & 25 & $2+$ V. 1 & - & 27 \\
$\quad$ Brushed & 1 & - & - & 1 \\
Brushed-Incised & 1 & - & - & 1 \\
Incised & 4 & V.1 section** & - & 4 \\
Incised-Punctated & - & 2 & - & 2 \\
Punctated & 19 & - & - & 3 \\
Fine & 2 & 1 & - & 3 \\
$\quad$ Engraved & 2 & $1 *$ & - & 62 \\
\hline Totals & 50 & $10+$ V. 1 & 2 & 3 \\
\hline
\end{tabular}

*one sherd is from a carinated bowl

**V. 1 section includes 70 mostly conjoined sherds

Two of the utility ware sherds from the McDonald site are from jars that have parallel brushed marks or parallel brushed-incised marks and lines. These are from Bullard Brushed vessels manufactured after ca. A.D. 1200. The four incised sherds, all from grog-tempered vessels, have the following decorative elements: diagonal opposed lines $(n=1)$, parallel incised lines $(n=1)$, and two lower rim sherds with between at least 2-5 horizontal incised lines. These sherds are likely either from Davis Incised or Kiam Incised vessels, and possibly a Dunkin Incised vessel, from an earlier component; such vessels were typically manufactured by East Texas Caddo peoples between ca. A.D. 900-1200. Brown et al. (1987) report two uncorrected radiocarbon dates of A.D. $940 \pm 70$ and A.D. $1170 \pm 70$ from the area of the site with the Early Caddo style ceramics.

The Vessel 1 section is a large grog-bone-tempered jar fired in a reducing environment and cooled in the open air. There are fire clouds on the exterior rim, body, and base; the interior surface is smoothed, and the vessel body is burnished. It stood at least $36.0 \mathrm{~cm}$ in height, with a direct rim, and with a $27.0 \mathrm{~cm}$ orifice diameter; it would have held at least 12 liters of food stuffs. The vessel rim is $7.9 \mathrm{~mm}$ in thickness, the body walls are $6.7 \mathrm{~mm}$ thick, and the base is $10.7 \mathrm{~mm}$ thick. The base diameter is $8.3 \mathrm{~cm}$. The rim panel is decorated with diagonal opposed incised lines (see Brown et al. 1987:Figure 38.16), and given many of the other sherds in the assemblage, Brown et al. (1987) reasonably identified the vessel as belonging to the Canton Incised type. Nevertheless, identical diagonal opposed incised elements occur regularly on postA.D. 1400 Maydelle Incised jars made by East Texas Caddo potters (see Suhm and Jelks 1962:Plate 52b).

Two incised-punctated jar rim sherds are from a Kiam Incised vessel (see Brown et al. 1987:Figure 38.17a). They have 10 closely-spaced horizontal incised lines and a single row of tool punctations at the rim-body juncture. The 19 grog-tempered punctated sherds are likely from the same vessel; they have rows of fingernail punctations, and may be from the body of a Kiam Incised jar.

The fine ware sherds include two grog-tempered body sherds with curvilinear engraved lines (see Brown et al. 1987:Figure 38.17f-g), one of these from a bottle, and the third engraved sherd (from a carinated bowl) has diagonal engraved lines. None of these sherds can be identified as a specific defined East Texas defined ceramic type. 
It is possible that the recovered ceramic vessel sherds at the McDonald site are associated with at least two occupations that had ancestral Caddo vessel sherds, one dating prior to A.D. 1200 (i.e., with Davis Incised and Kiam Incised vessel sherds) and the other after ca. A.D. 1200 (i.e., with Canton of Maydelle Incised and brushed, brushed-incised vessel sherds). The available corrected radiocarbon dates from ceramic bearing deposits at the site range from A.D. 890-1185 to A.D. 1190-1315 (Brown et al. 1987:Table 38.4).

Brown et al. (1987:38-109) have suggested that the McDonald site ceramics were not made in the Caddo area, primarily because the colors of the clay bodies are "not typical of those from the central Caddoan [sic] region, which tends more towards the red and browns." The color of the ceramic vessels after firing, however, are not an adequate means to identify local vs. non-local ceramics; differences in how vessels were fired, then subsequently cooled, as well as differences in the composition of clay sources, can cause considerable variation in ceramic body colors. Dark brown and black colors of ceramic bodies, as with the McDonald site ceramics, can be expected whenever a vessel was fired in a reducing or low oxygen environment, regardless of the clay source.

\section{$41 H 1109$}

This prehistoric site is on an upland landform overlooking Hackberry Creek, a tributary to Aquilla Creek in the Aquilla Creek project area (Brown et al. 1987:23-1). A single ceramic sherd had been collected from the surface of the site during the 1972 survey of the proposed lake. The sherd has a sandy paste and is bone-tempered; it also has brushing marks on the exterior and interior surfaces (Brown et al. 1987:23-27). If this sherd is truly from a vessel that has been brushed on both vessel surfaces, there would be little likelihood that it was from an ancestral Caddo vessel; interior surfaces are usually simply smoothed, and not decorated. However, if the interior "brushing" is a surface treatment such as wiping, and not a decorative element - as would be the case for post-A.D. 1200 exterior brushed ceramics - then the 41HI109 sherd may well be from an ancestral East Texas Caddo vessel.

\section{$41 H I 111$}

Five plain body sherds with exterior smoothed surfaces were recovered from investigations at 41HI111 at Aquilla Lake. Three are described as having clay grit inclusions, which I interpret as meaning the sherds have grog particles and a sandy paste, plus bone temper (Brown et al. 1987:25-15 to 25-16), and another has a sandy paste with infrequent inclusions bone inclusions. The possible grog-tempered sherds at the site may be from an ancestral Caddo ceramic vessel. Brown et al. (1987:25-19) suggest that the component that has the ceramic sherds, and a few arrow points, may date to the "earlier Late Prehistoric," probably predating ca. A.D. 1000.

\section{$41 H I 134$}

A single grog-tempered Bullard Brushed rim sherd (INAA, UT0005) in the TARL collections has been recovered from this site on Hackberry Creek at Aquilla Lake in the central Brazos River basin (see Skinner 1972:Figure 5b). The site is on an upland slope landform overlooking the creek. The brushing marks on the rim sherd are both diagonal and vertical in orientation on the jar rim. Brown et al. (1987:4853) suggest that other ceramics at the site are from a Toyah phase occupation; the brushed Caddo sherd would be temporally consistent with a post-A.D. 1200 occupation. 


\section{Indian Springs (41HI210)}

A single Caddo vessel sherd was recovered from the Indian Springs site in the Brazos River basin. It has been described as having a fine paste, vessel walls that have been smoothed and/or burnished, and possibly having a slipped surface (Skinner and Gallagher 1974:66). If the vessel was tempered during manufacture, Skinner and Gallagher (1974) did not mention it.

\section{$41 H I 237$}

Skinner (1972:Figure 5a) illustrates a parallel brushed body sherd from this site at Aquilla Reservoir; the report, unfortunately, provides no further information or description of this ancestral Caddo sherd. The site has a midden deposit along the edge of the Aquilla Creek floodplain.

\section{$41 H I 239$}

This site has three grog-tempered Caddo vessel sherds, all body sherds. Two of the sherds had been analyzed for INAA (UT00001 and UT00002). One of the body sherds has parallel brushing marks, suggesting the site's use after ca. A.D. 1200, when this kind of ceramic vessel was first being made in quantity by East Texas Caddo potters (see Perttula 2013).

\section{$41 H I 241$}

There are five Caddo vessel sherds in the collections from 41HI241 at TARL, including one plain grog-bone-tempered body sherd that was submitted for INAA (UT00003, see Creel et al. 2013). Three sherds are from grog-tempered vessels and two are from grog-bone-tempered vessels.

One of the grog-tempered sherds has an interior red-slipped surface, as well as an interior thickened area at the lower rim of the vessel, likely a bowl or carinated bowl. The other decorated sherd, from a jar, has parallel brushing marks on its exterior surface. The occurrence of a brushed sherd at the site also suggests its use after ca. A.D. 1200, as does the red-slipped sherd, when both kinds of ceramic vessels were being made by East Texas Caddo potters.

\section{Little Buzzard Shelter or Cave}

The initial investigations of Little Buzzard Shelter in 1947 by Stephenson (1970:269-270) did not recover any ceramic vessel sherds. However, in later work, there were sherds from six different vessels in the archaeological deposits at Little Buzzard Shelter or Cave (Long 1961:228 and Figure 5h-j). Three (represented by four sherds) have engraved decorative elements, and may be from Holly Fine Engraved and Sanders Engraved vessels (although from the illustrated sherds, it is difficult to discern clear decorative elements of either type). Two other vessels (with four sherds) may be of the Goose Creek Plain, var. unspecified type, and Vessel VI includes only one thin (3-4 mm thick) body sherd with "grit and bone temper." The ancestral Caddo sherds from Little Buzzard Shelter or Cave may be contemporaneous with those present at Buzzard Cave, although the possible Sanders Engraved vessel may suggest some use of Little Buzzard Shelter or Cave after ca. A.D. 1200.

\section{A5-11/15}

This site is in the Navasota River basin in the western part of Hill County. Frank Watt collected 41 rim and body sherds here from grog- and grog-bone-tempered vessels (Table 19). Sherds from vessels tempered 
only with grog represent approximately 93 percent of the sherds, and the remaining 7.3 percent of the sherds have some amount of burned bone added to the paste.

Table 19. Ceramic sherds from 40A5-11/15 in Hill County, Texas.

\begin{tabular}{llll}
\hline Ware & Grog-tempered & Grog-bone-tempered & N \\
\hline Plain & 21 & 2 & 23 \\
Utility & 16 & - & 16 \\
incised & 4 & - & 4 \\
incised-punctated & 3 & - & 3 \\
punctated & 9 & - & 9 \\
Fine & 1 & 1 & 2 \\
$\quad$ engraved & 1 & 1 & 2 \\
\hline \multirow{2}{*}{ Totals } & 38 & 3 & 41 \\
\hline
\end{tabular}

Almost 90 percent of the decorated sherds $(n=18)$ are from utility wares, and these include sherds from vessels with incised, incised-punctated, and punctated decorative elements. The incised sherds include a rim sherd with horizontal incised lines (probably from a Davis Incised vessel), a body sherd with horizontal and diagonal incised lines (Figure 36d), and body sherds with parallel incised lines $(n=2)$. One of the incisedpunctated body sherds, likely from a Pennington Punctated-Incised vessel, has an incised panel filled with tool punctations, and the other (from a Dunkin Incised vessel) has a row of tool punctations at the rim-body juncture and vertical incised lines on the rim itself. The punctated body sherds have both rows of fingernail punctates ( $\mathrm{n}=8$ ) (Figure 36c) and rows of tool punctations (Figure 36b). Both fine ware sherds have engraved decorative elements, including parallel engraved lines or curvilinear engraved lines (Figure 36a).

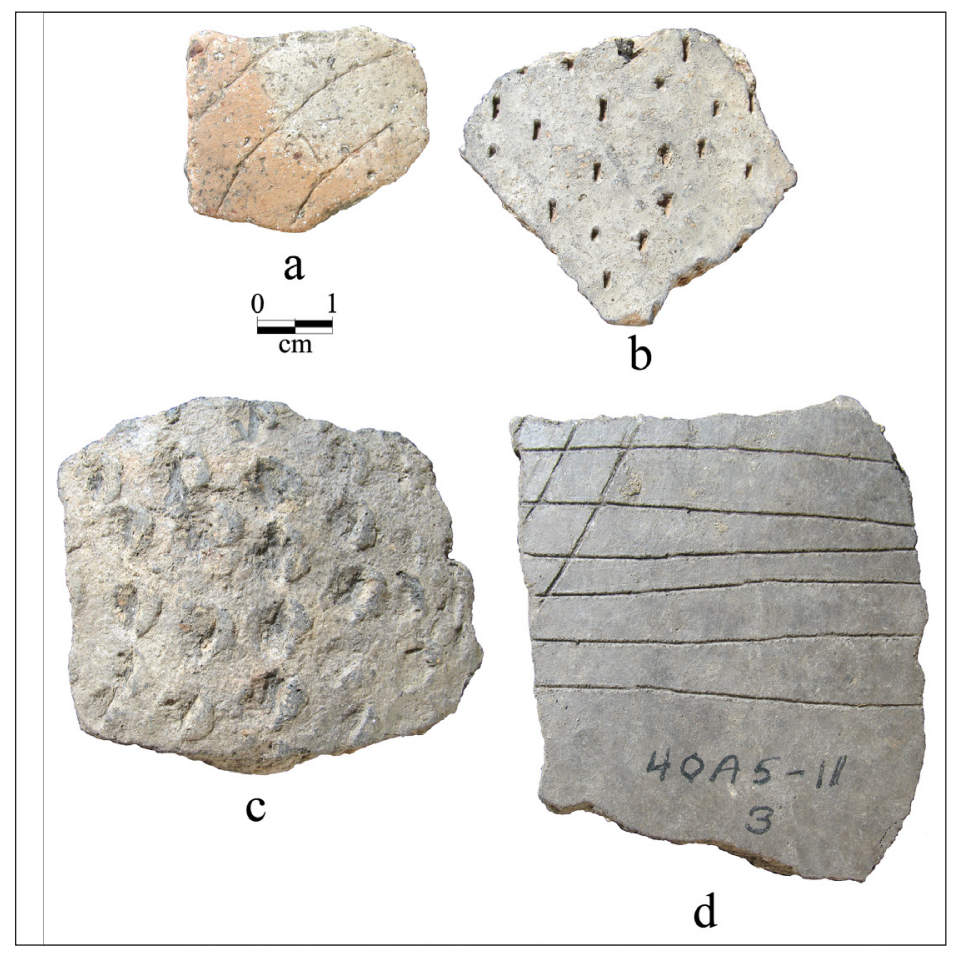

Figure 36. Selected decorated sherds from 40A5-11/15 in Hill County, Texas. 
The range of decorative elements in this assemblage, as well as the absent of sherds with brushing marks, suggests that the sherds from this Hill County site date to some part of the Early Caddo period. They likely originated in the Neches River basin.

\section{Frank Bryan Collection, Hill and McLennan County Sites}

Frank Bryan was an active collector of Native American artifacts in Hill and McLennan counties in the 1920s and 1930s (Bryan 1935, 1936, 1937). In Bryan (1937:72 and Map 4), he mentioned two sites (No. 2 and No. 4) along Aquilla Creek in Hill County had ceramic vessel sherds, and noted "the pottery is of a much lighter color than that found along the Navasota and Richland creek [in Limestone and Navarro counties]. However the markings are similar. In these two camps the pottery is in limited areas." He also mentioned the site near the Cement Plant in McLennan County - also known as the Cement Hill site (41ML43) - as having two pottery sherds found during his investigations, both engraved (see Bryan 1936:Plate XV:M-M).

His collection was donated to The University of Texas at Austin at some unknown point, and there are significant quantities of ancestral Caddo ceramics from 15 different sites in the collections at the Texas Archeological Research Laboratory. The sherds are designated with a three-digit number; the specific provenience of these sherds in the counties is not known. Thirteen of the sites have only between 1-4 sherds per site, but Site 377 has 197 plain, utility, and fine ware sherds, while Site 390 has 173 sherds from all three wares.

The one fine ware sherd from Site 140 is a body sherd with parallel engraved lines (Table 20). The age of this ancestral Caddo sherd is unknown except that is postdates ca. A.D. 800/850, when ancestral Caddo ceramic vessels began to be made in East Texas.

Table 20. Ceramic Wares from Site 140 in the Bryan Collection.

Ware Grog-tempered

Fine ware $\quad 1$

Totals 1

The ceramic sherds from Site 372 are plain body $(n=4)$ sherds (Table 21) of post-A.D. 800/850 Caddo ceramic vessels.

Table 21. Ceramic Wares from Site 372 in the Bryan Collection.

Ware Grog-tempered

Plain ware 4

Totals

4 
The one body sherd from Site 373 has two horizontal and diagonal rows of fingernail punctations (Table 22), probably from a Weches Fingernail Impressed, var. Alto vessel (Stokes and Woodring 1981:Figure 22m). Such vessels were made in Formative and Early Caddo period times in East Texas.

Table 22. Ceramic Wares from Site 373 in the Bryan Collection.

Ware Grog-tempered

Utility ware 1

Totals 1

Site 375 has a body sherd from a Dunkin Incised vessel with incised-punctated elements (Table 23) (see Suhm and Jelks 1962:Plate 19). These consist of horizontal and diagonal incised lines on the lower rim, and at least two rows of tool punctations on the upper body (Figure 37). These vessels were made in Formative and Early Caddo period times in East Texas.

Table 23. Ceramic Wares from Site 375 in the Bryan Collection.

Ware Grog-Bone-tempered

Utility 1

Totals 1

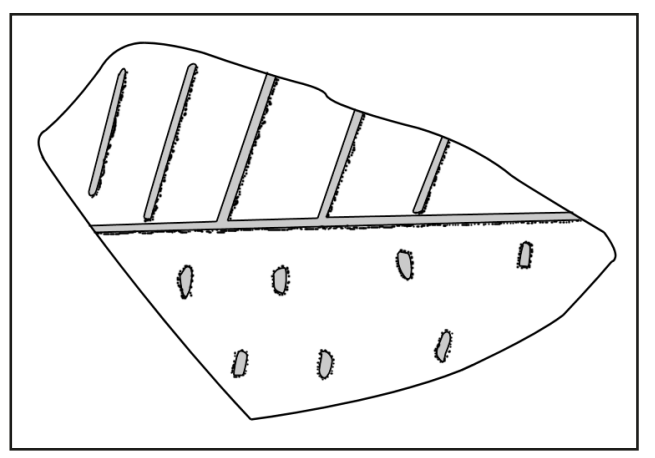

Figure 37 . Decorative elements on
Dunkin Incised vessel sherd from Site
375 in the Frank Bryan Collection.

The 197 vessel sherds from Site 377 include plain wares (72.1 percent), utility wares (24.9 percent), and fine wares (3.0 percent). These vessels have primarily been tempered with grog (94.9 percent), either as the sole temper, or in conjunction with bone (20.0 percent of the sherds) or hematite ( 0.5 percent) (Table 24). Another 3.6 percent have either bone or bone-hematite temper, and 1.5 percent of the sherds are from Goose Creek Plain, var. unspecified vessels (Story 1990a). The latter are from a Woodland period use of the site, while the remainder of the sherds are from ancestral Caddo vessels. The decorated sherds $(\mathrm{n}=55)$ are discussed below, together with the decorated sherd assemblage from Site 390. 
Table 24. Ceramic Wares from Site 377 in the Bryan Collection.

\begin{tabular}{llllllll}
\hline Ware & G & G-B & G-H & B & B-H & SP & N \\
\hline Plain ware & 103 & 31 & 1 & 3 & 1 & 3 & 142 \\
Utility ware & 39 & 7 & - & 3 & - & - & 49 \\
Fine ware & 5 & 1 & - & - & - & - & 6 \\
\hline Totals & 147 & 39 & 1 & 6 & 1 & 3 & 197 \\
\hline
\end{tabular}

$\mathrm{G}=$ grog-tempered; $\mathrm{G}-\mathrm{B}=$ grog-bone-tempered; $\mathrm{G}$-H=grog-hematite-tempered; $\mathrm{B}=$ bone-tempered; $\mathrm{B}$-H=bonehematite-tempered; $\mathrm{SP}=$ sandy paste

Both sherds from Site 383 are probably from the same grog-tempered vessel, a fine vessel with engraved decorative elements and a red slip on both interior and exterior vessel surfaces (Table 25). This vessel has a broad horizontal engraved band filled with cross-hatched engraved lines as well as a narrower horizontal engraved band with vertical hatched engraved lines (Figure 38). Horizontal and vertical bands and ladder elements are most frequent in Middle Caddo period (ca. A.D. 1200-1400) ceramic assemblages in East Texas (Perttula 2013:192).

Table 25. Ceramic Wares from Site 383 in the Bryan Collection.

Ware Grog-tempered

Fine ware 2

Totals 2

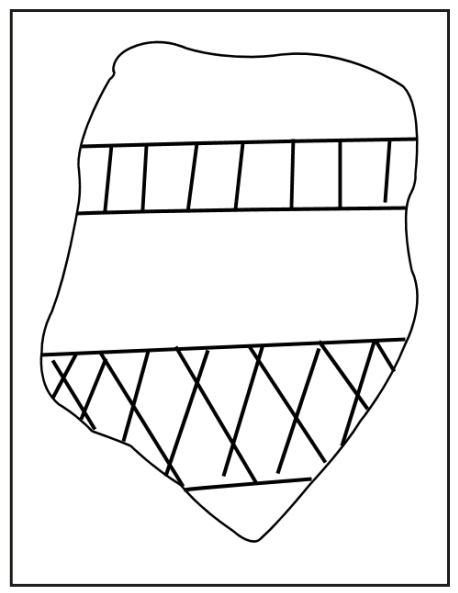

Figure 38. Decorative elements on an engraved sherd from Site 383 in the Frank Bryan collection.

The one sherd from Site 384 is a rim from a utility ware vessel (Table 26), likely a Dunkin Incised jar, with incised decorative elements. This rim sherd has a single horizontal incised line below the lip and a series of large incised triangles filled with diagonal incised lines pitched in opposite directions (Figure 39). 
Table 26. Ceramic Wares from Site 384 in the Bryan Collection.

\begin{tabular}{lc} 
Ware & Grog-Bone-tempered \\
\hline Utility ware & 1 \\
\hline Totals & 1 \\
\hline
\end{tabular}

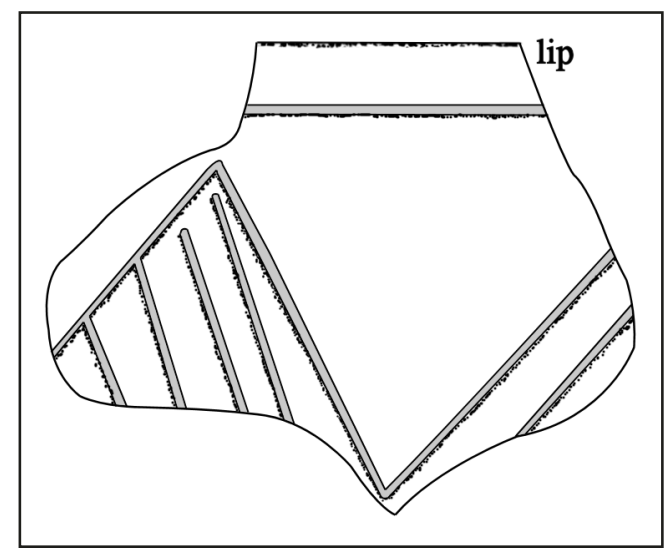

Figure 39. Decorative elements on incised rim sherd from Site 384 in the Frank Bryan Collection.

Site 385 has only a single ancestral Caddo ceramic sherd. This is a plain grog-bone-tempered body sherd (Table 27).

Table 27. Ceramic Wares from Site 385 in the Bryan Collection.

\begin{tabular}{lc}
\hline Ware & Grog-Bone-tempered \\
\hline Plain ware & 1 \\
\hline Totals & 1 \\
\hline
\end{tabular}

Site 386 also has only a single ancestral Caddo ceramic sherd. This is a plain grog-tempered body sherd (Table 28).

Table 28. Ceramic Wares from Site 386 in the Bryan Collection.

\begin{tabular}{lc}
\hline Ware & Grog-tempered \\
\hline Plain ware & 1 \\
\hline Totals & 1 \\
\hline
\end{tabular}


There are four plain sherds from Site 387 (Table 29). These include one plain body sherd and two base sherds from grog-tempered vessels, and one body sherd from a grog-bone-tempered vessel.

Table 29. Ceramic Wares from Site 387 in the Bryan Collection.

\begin{tabular}{llll}
\hline Ware & Grog-tempered & Grog-Bone-tempered & N \\
\hline Plain ware & 3 & 1 & 4 \\
\hline Totals & 3 & 1 & 4 \\
\hline
\end{tabular}

The one body sherd from Site 388 (Table 30) is from a grog-tempered vessel with at least three rows of fingernail punctations. This sherd may be from a Dunkin Incised or Kiam Incised vessel (see Suhm and Jelks 1962:Plate 45); both types were made in Formative and Early Caddo period times in East Texas.

Table 30. Ceramic Wares from Site 388 in the Bryan Collection.

\begin{tabular}{lcc}
\hline Ware & Grog-tempered & $\mathrm{N}$ \\
\hline Utility ware & 1 & 1 \\
\hline Totals & 1 & 1 \\
\hline
\end{tabular}

The ceramic vessel sherds from Site 390 include sherds from plain ware (70.5 percent), utility ware (23.1 percent), and fine ware (6.4 percent) vessels (Table 31$)$; these proportions are very little different from Site 377 (see Table 24). Almost 94 percent of the vessel sherds from the site are tempered with grog, grog-bone, or grog-hematite. About 4.6 percent of the sherds are tempered solely with burned bone. The remainder of the vessel sherd assemblage from the site are three body sherds (1.7 percent) from Woodland period Goose Creek Plain, var. unspecified vessels (see Story 1990a).

Table 31. Ceramic Wares from Site 390 in the Bryan Collection.

\begin{tabular}{lllllll}
\hline Ware & G & G-B & G-H & B & SP & N \\
\hline Plain ware & 88 & 22 & 2 & 7 & 3 & 122 \\
Utility ware & 36 & 2 & 1 & 1 & - & 40 \\
Fine ware & 10 & 1 & - & - & - & 11 \\
\hline Totals & 134 & 25 & 3 & 8 & 3 & 173 \\
\hline
\end{tabular}

$\mathrm{G}=$ grog=tempered; $\mathrm{G}-\mathrm{B}=$ grog-bone-tempered; $\mathrm{G}-\mathrm{H}=$ grog-hematite-tempered; $\mathrm{B}=$ bone-tempered; $\mathrm{SP}=$ sandy paste

The two grog-tempered fine ware sherds from Site 391 (Table 32) have a narrow and engraved circle element filled with hatched lines (Figure 40a-b). A red pigment has been rubbed in the engraved lines on one of the sherds. These sherds may be related to several regional varieties of Poynor Engraved defined in the upper Neches River basin in East Texas (Perttula 2011:Figure 6-65). 
Table 32. Ceramic Wares from Site 391 in the Bryan Collection.

Ware Grog-tempered

Fine ware

2

Totals

2

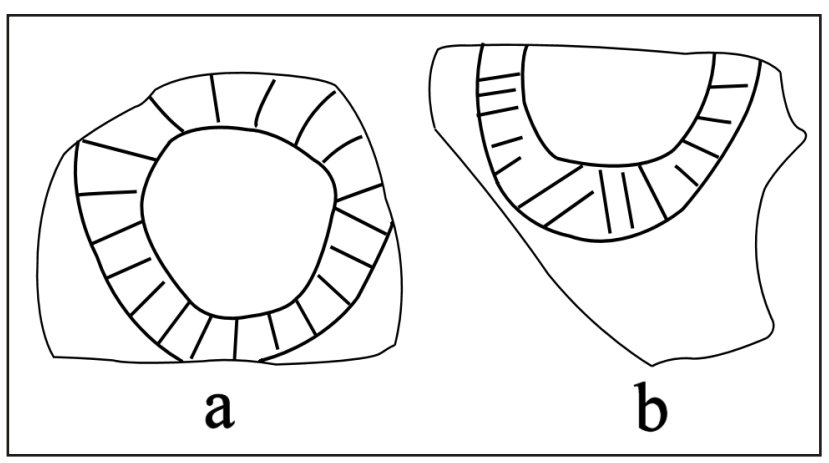

Figure 40. Decorative elements on engraved sherds from Site 391 in the Bryan collection.

The one utility ware sherd from Site 392 is a grog-tempered rim sherd (Table 33) from a Pennington Punctated-Incised carinated bowl (Figure 41, see also Suhm and Jelks 1962:Plate 61). The rim panel has upper and lower horizontal incised lines as well as upper and lower incised triangles filled with circular punctations. This pottery type was generally made in Formative and Early Caddo periods in East Texas sites.

Table 33. Ceramic Wares from Site 392 in the Bryan Collection.

Ware Grog-tempered

Utility

1

Totals

1

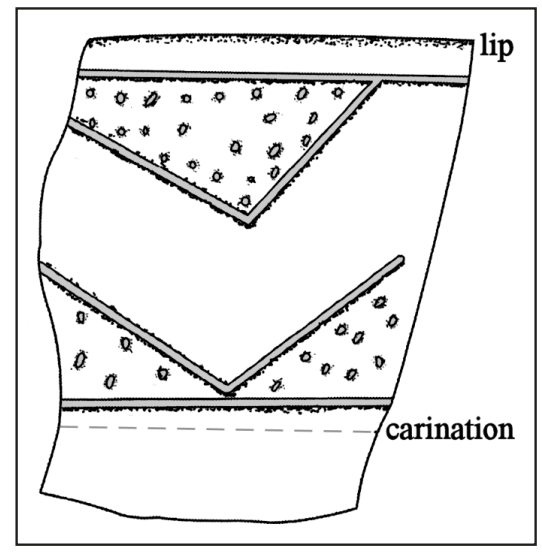

Figure 41. Decorative elements on Pennington PunctatedIncised rim sherd from Site 392. 
Site 393 has three decorated grog-tempered sherds (Table 34). The one utility ware sherd is a rim from another Formative to Early Caddo period Pennington Punctated-Incised carinated bowl. This rim has horizontal incised lines at the top and bottom of the rim panel, and diagonal incised bands filled with circular punctations (Figure 42a).

Table 34. Ceramic Wares from Site 393 in the Bryan Collection.

Ware

Grog-tempered

$\begin{array}{ll}\text { Utility ware } & 1 \\ \text { Fine ware } & 2\end{array}$

Totals

3

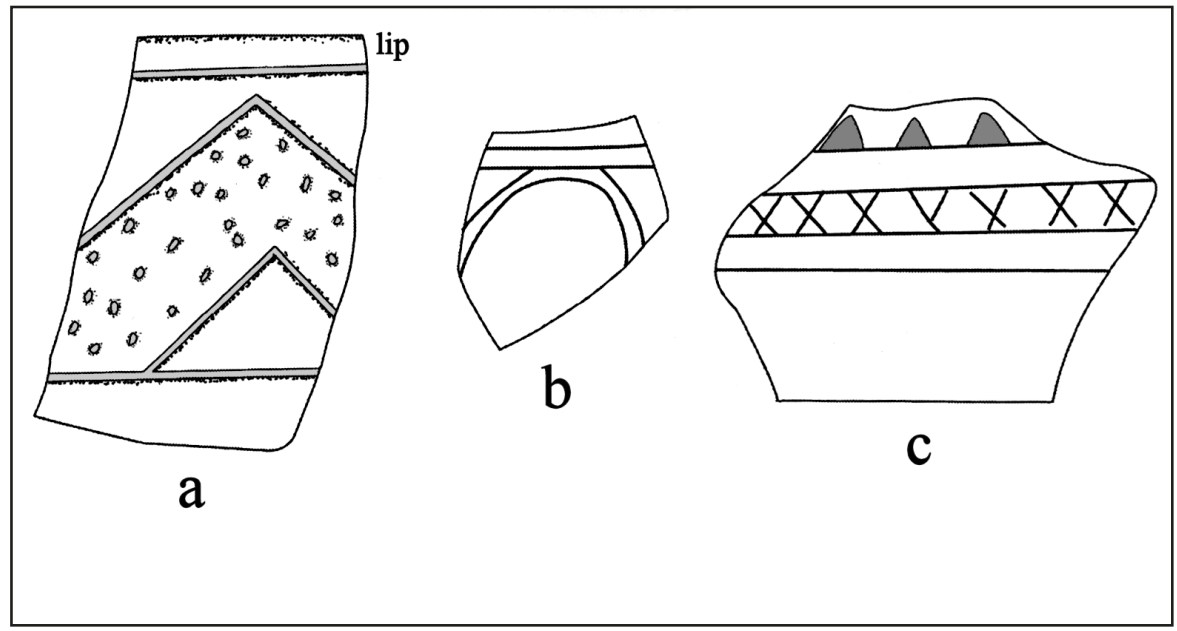

Figure 42. Decorative elements on sherds from Site 393 in the Bryan collection.

One of the fine ware body sherds from Site 393 is from a Poynor Engraved, var. Cook vessel with an oval decorative element defined by vertical arcing lines (see Figure 42b, see Perttula 2011:Figure 6-64); there are two horizontal engraved lines immediately above the engraved oval. Poynor Engraved, var. Cook vessels occur in ca. A.D. 1400-1650 burial features in the upper Neches River basin, and are most common in ca. A.D. 1480-1560 components (Perttula 2011:Table 6-37). The second engraved sherd from the site may be from a Hume Engraved vessel (see Figure 42c). It has a horizontal row of excised pendant triangles above a narrow horizontal zone filled with cross-hatched engraved line, followed by a single horizontal engraved line. In the upper Neches River basin, Hume Engraved vessels began to be made after ca. A.D. 1480, in the Late Caddo Frankston phase, and become more common from the time of the Frankston phase to the post-A.D. 1680 Allen phase (Perttula 2011:283 and Table 6-37).

In the case of the larger assemblages of decorated sherds from Site 377 and Site 390, utility ware sherds are by far the most common at both sites: 89 percent of the decorated sherds at Site 377 and 78.4 percent at Site 390 (Tables 35 and 36). Sherds from utility ware vessels with either incised or punctated decorative elements dominate both the Site 377 and Site 390 assemblages. A few sherds at both sites have incised-punctated decorative elements (5.9-7.3 percent), there is one incised-pinched sherd from Site 390, and an appliqued lug handle at Site 390. Sherds with brushing marks, or with brushed-incised marks and 
lines are present at both sites, indicating some use of the sites after ca. A.D. 1200, when brushed utility wares became a common feature of ancestral Caddo ceramics in several parts of East Texas, including the Neches-Angelina, Sabine, and Big Cypress stream basins (Perttula 2013). Brushed or brushed-incised sherds comprise 5.4 percent of the decorated sherds at Site 377 and 13.7 percent of the decorated sherds at Site 390.

Table 35. Decorative methods and elements in the Site 377 ceramic assemblage.

\begin{tabular}{llll}
\hline Decorative method and elements & Rim & Body & $\mathrm{N}$ \\
\hline
\end{tabular}

Utility Ware

Brushed-Incised

horizontal-diagonal brushed-incised marks and lines*

horizontal-diagonal incised lines [rim] and vertical brushed [body] parallel brushed-incised marks and lines

\section{Incised}

diagonal incised lines

diagonal opposed incised lines

diagonal-vertical incised lines

horizontal incised lines-curvilinear incised lines

(Crockett Curvilinear Incised)

horizontal and vertical sets of incised lines

opposed incised lines

closely-spaced parallel incised lines

parallel incised lines

straight incised line

discontinuous vertical incised lines

Incised-Punctated

circular incised zone filled with punctations

(Crockett Curvilinear Incised)

diagonal incised zones filled with tool punctations

horizontal incised line-rows of large thumbnail punctations (Weches Fingernail Impressed)

incised diagonal bands filled with tool punctations

(Pennington Punctated-Incised)

\section{Punctated}

circular tool punctated rows

fingernail punctated rows

tool punctated row/rows

tool punctated row at rim-body juncture

\section{Fine Ware}

\section{Engraved}

diagonal opposed engraved lines and narrow zones with cross-hatched engraved lines (Poynor Engraved)

horizontal hatched zone under lip and rectilinear zone filled with curvilinear engraved lines

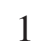

1

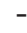

$\begin{array}{lll}1 & - & 1\end{array}$

325

$\begin{array}{lll}- & 1 & 1\end{array}$

$\begin{array}{lll}- & 1 & 1\end{array}$

$\begin{array}{lll}- & 1 & 1\end{array}$

$\begin{array}{lll}- & 1 & 1\end{array}$

$\begin{array}{lll}- & 1 & 1\end{array}$

$\begin{array}{lll}- & 6 & 6\end{array}$

$\begin{array}{lll}- & 3 & 3\end{array}$

$\begin{array}{ccc}- & 1 & 1\end{array}$

$\begin{array}{lll}- & 1 & 1\end{array}$

$1 \quad-1$

$\begin{array}{ccc}- & 1 & 1\end{array}$

$\begin{array}{lll}1 & - & 1\end{array}$

$\begin{array}{lll}- & 1 & 1 \\ - & 16 & 16 \\ - & 3 & 3 \\ - & 1 & 1\end{array}$

16

3

1 
Table 35. Decorative methods and elements in the Site 377 ceramic assemblage, continued.

\begin{tabular}{llll}
\hline Decorative method and elements & Rim & Body & N \\
\hline parallel engraved lines & - & 1 & 1 \\
straight engraved line & - & 1 & 1 \\
straight engraved line with excised pendant triangles & - & 1 & 1 \\
$\begin{array}{l}\text { (Hume Engraved) } \\
\text { vertical hatched zone (Hume Engraved) }\end{array}$ & - & 1 & 1 \\
\hline Totals & 9 & 46 & 55 \\
\hline
\end{tabular}

*sherd has a $6.0 \mathrm{~mm}$ diameter suspension hole below the lip

Table 36. Decorative methods and elements in the Site 390 ceramic assemblage.

\begin{tabular}{llll}
\hline Decorative method and elements & Rim & Body & $\mathrm{N}$ \\
\hline
\end{tabular}

\section{Utility Ware}

\section{Appliqued}

vertical appliqued ridges on lug handle

\section{Brushed}

parallel brushing marks

\section{Brushed-Incised}

parallel brushed-incised marks and lines

parallel brushing marks-overlying opposed incised

lines (Spradley Brushed-Incised)

\section{Incised}

cross-hatched incised lines

diagonal incised line

diagonal opposed incised lines

horizontal-diagonal incised lines

horizontal incised line at rim-body juncture

horizontal incised lines-zig-zag incised el.

nested incised triangle el.

opposed incised lines

parallel incised lines

vertical incised lines

\section{Incised-Pinched}

straight incised line and vertical pinched ridges

(Killough Pinched)

\section{Incised-Punctated}

diagonal opposed incised lines-rows of linear tool punctations

set of vertical incised lines-diagonal linear punctated el. straight incised line-adjacent zone of tool punctated rows 
Table 35. Decorative methods and elements in the Site 377 ceramic assemblage, continued.

\begin{tabular}{|c|c|c|c|}
\hline Decorative method and elements & Rim & Body & $\mathrm{N}$ \\
\hline \multicolumn{4}{|l|}{ Punctated } \\
\hline cane punctated rows & - & 1 & 1 \\
\hline fingernail punctated row & - & 8 & 8 \\
\hline tool punctated row & - & 1 & 1 \\
\hline \multicolumn{4}{|l|}{ Fine Ware } \\
\hline \multicolumn{4}{|l|}{ Engraved } \\
\hline curvilinear engraved lines & - & 1 & 1 \\
\hline diagonal engraved line & 1 & - & 1 \\
\hline $\begin{array}{l}\text { diagonal hatched engraved zone } \\
\text { (Poynor Engraved) }\end{array}$ & - & 1 & 1 \\
\hline $\begin{array}{l}\text { horizontal engraved line with excised tick marks } \\
\text { (Patton Engraved) }\end{array}$ & - & 1 & 1 \\
\hline horizontal engraved line, int. vessel surface & - & 1 & 1 \\
\hline horizontal-diagonal-vertical engraved lines & - & 1 & 1 \\
\hline $\begin{array}{l}\text { oval engraved el. with hatched zone } \\
\text { (Poynor Engraved) }\end{array}$ & - & 1 & 1 \\
\hline parallel engraved lines & - & 1 & 1 \\
\hline straight engraved line & - & 3 & 3 \\
\hline Totals & 8 & 43 & 51 \\
\hline
\end{tabular}

Based on the stylistic character of the utility ware and fine ware sherds at the two sites, the principal occupation of Site 377 and Site 390 was from ca. A.D. 900-1200, during the Early Caddo period in East Texas. Both sites also have ancestral Caddo pottery that was made during the Late Caddo period Frankston phase (ca. A.D. 1400-1680), and there is evidence of Historic Caddo period Allen phase ceramics dating between ca. A.D. 1680-1720 at Site 390, including one sherd each from Patton Engraved (Figure 44f) and Spradley Brushed-Incised vessels (see Table 36).

The Early Caddo period ceramics at both sites includes sherds from Crockett Curvilinear Incised (Figure 43a, e), Dunkin Incised (Figures 43b-d and 44a-c), Kiam Incised, Pennington Punctated-Incised (Figure 43g), and Weches Fingernail Impressed (Figure 43f; most of the fingernail punctated sherds at both sites are likely from this type), var. Alto and var. Weches vessels (see Stokes and Woodring 1981), and sherds from these vessels are the most abundantly represented in the decorated utility ware sherds. No fine wares in the assemblage can be clearly identified as coming from an Early Caddo period engraved vessel, except perhaps for one sherd from Site 390 with horizontal-vertical-diagonal engraved lines and another sherd with a single horizontal engraved line on its interior vessel surface (see Table 35).

The Late Caddo period Frankston phase ceramics at both sites include utility wares, among them brushed and brushed-incised sherds from Bullard Brushed vessels (see Tables 34 and 35), and a sherd from a Killough Pinched jar. Fine wares from Poynor Engraved (see Figure 44d) and/or Hume Engraved vessels (see Figures 43h-i and 44e) are represented in the sherds from the two sites. The occurrence of Hume Engraved suggests that the sherds came from vessels made in East Texas after ca. A.D. 1480 (Perttula 2011:268). 


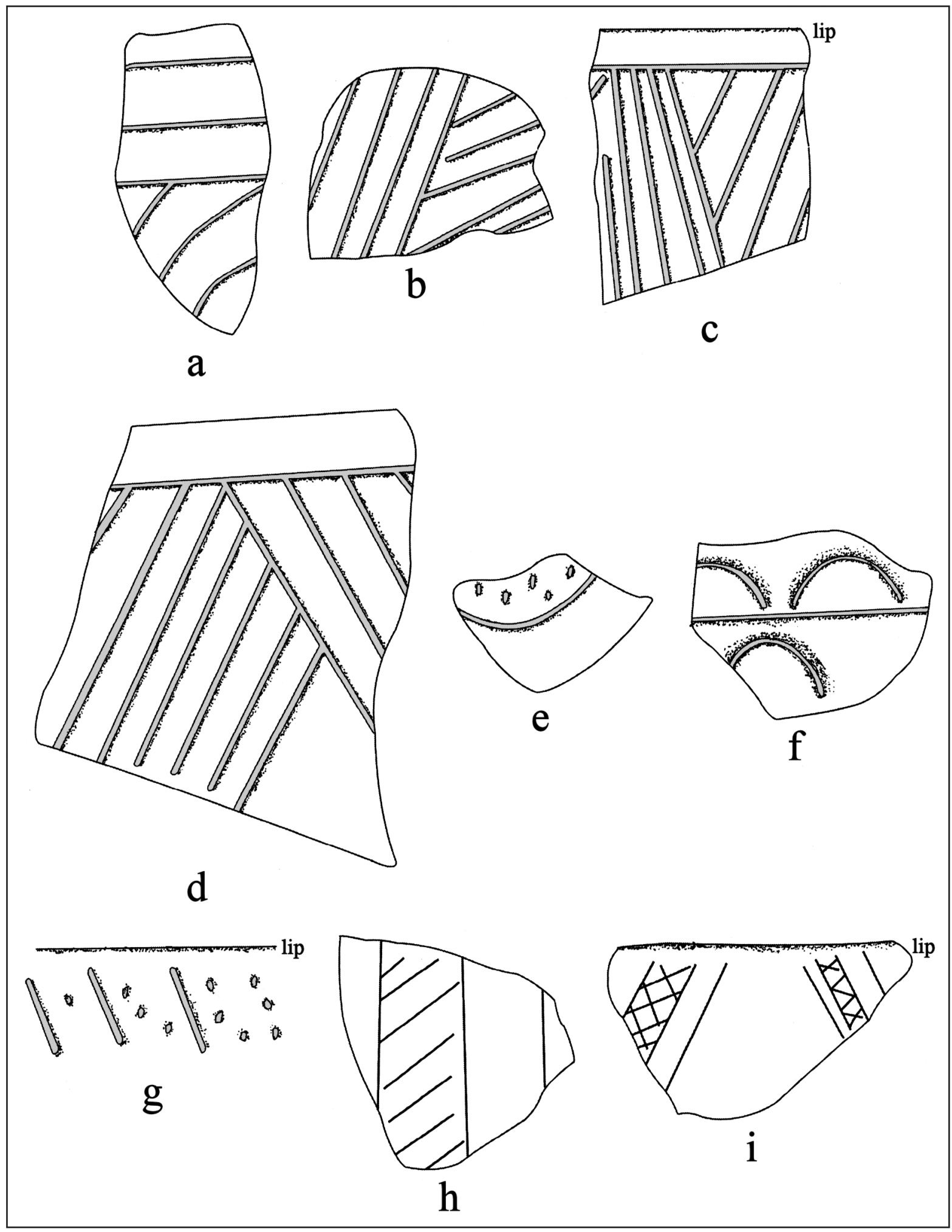

Figure 43. Selected decorative elements on sherds from Site 377 in the Bryan collection. 


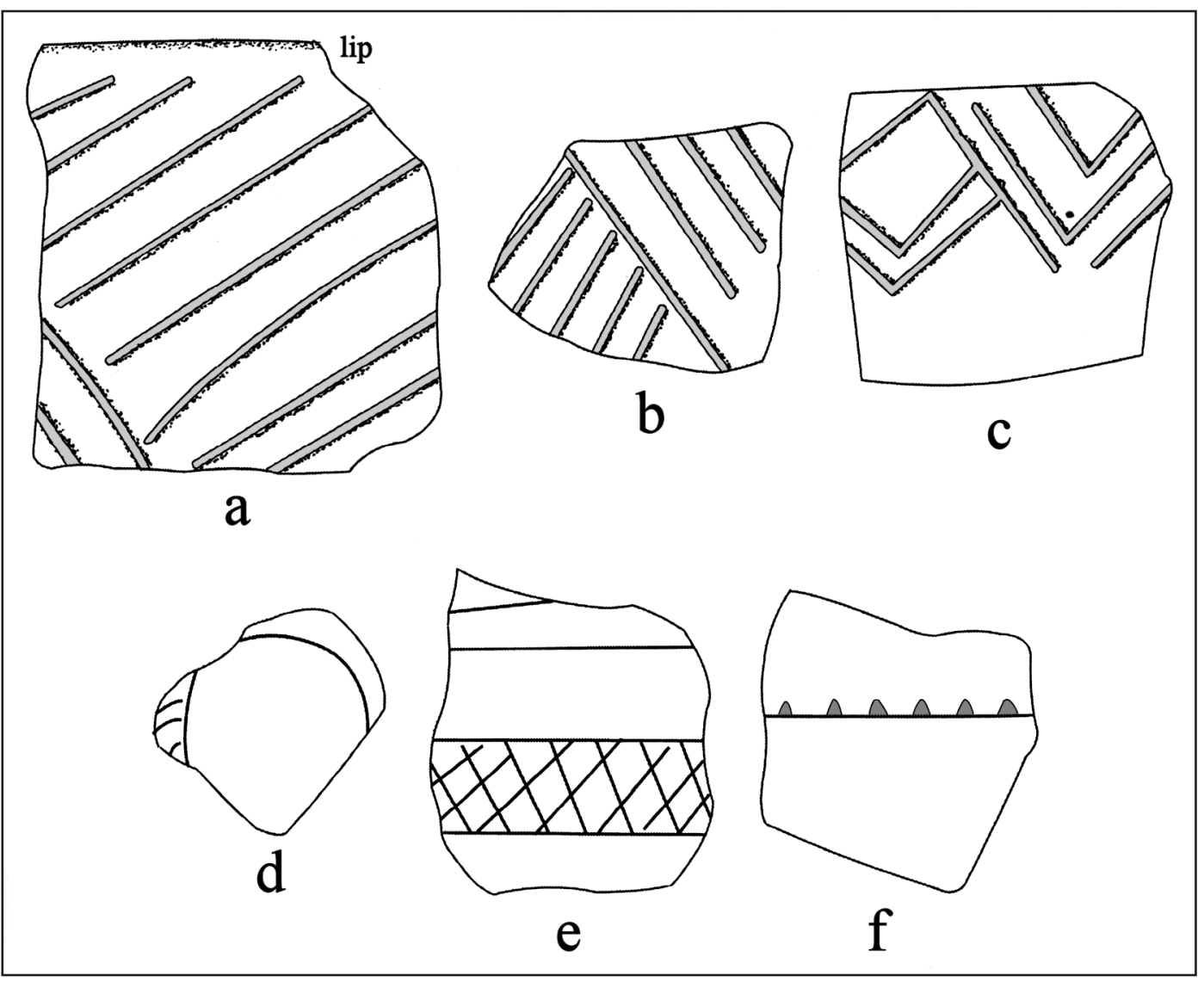

Figure 44. Selected decorative elements on sherds from Site 390 in the Bryan Collection.

\section{Irion County}

\section{IR28}

The TARL collections have a cf. Poynor Engraved bottle sherd (INAA, UT00223) with a triangular engraved zone filled with hatched lines. The sherd came from a grog-tempered vessel that was made by a Frankston phase Caddo potter after ca. A.D. 1400.

\section{$41 I R 38$}

In addition to Toyah phase Leon Plain sherds, there are grog and bone-tempered Caddo ceramic sherds in the assemblage of 66 sherds collected by Creel (1990:143). There are two plain grog-tempered rim or body sherds and eight decorated sherds. One rim sherd from a LaRue Neck Banded jar has two or more neck banded rows, four sherds (including INAA UT00198 and UT00201) from Bullard Brushed vessels have parallel brushing marks, two others have parallel brushed-incised marks and lines, and a Bullard Brushed rim has horizontal brushing marks with a row of fingernail punctations pushed through the brushing at the mid-rim. 


\section{Sugg TD Ranch (41IR50)}

The TARL collection from the Sugg TD Ranch has six brushed body sherds with bone temper (including INAA UT00262). Brushed bone-tempered Caddo pottery dating after ca. A.D. 1400 is quite common in the Angelina and mid-Sabine River basins in East Texas (see Perttula 2015a:Figure 11), and these sherds likely are from one or more vessels manufactured by ancestral Caddo potters in that part of East Texas.

\section{Kendall County}

\section{KE66}

This site on the Guadalupe River has an ancestral Caddo Poynor Engraved sherd (Neureuther 1984). This is indicative of the use of this rock art site after ca. A.D. 1400.

\section{Unrecorded site north of Comfort, Texas}

Chandler (1995:27-28) reports on a partially reconstructed everted rim jar with four or five parallel rows of punctations on the rim; the jar has a rounded rather than a flat base. The vessel appears to be associated with the use of Edwards arrow points, dating to the $10^{\text {th }}$ and $11^{\text {th }}$ centuries A.D.

\section{Kerr County}

\section{Unrecorded site near Hunt, Texas}

A T-shaped ceramic tubular pipe has been found on a midden site near Hunt, Texas, in Kerr County (Chandler 1995:Figure 1). Chandler (1995:27) notes that such a pipe style "is well documented in northeast Texas and eastern Oklahoma... There is growing evidence for the movement of Caddoan [sic] ceramics well into south central Texas."

\section{Lampasas County}

\section{Salt Creek}

A surface collection at a site at the confluence of Salty Creek and the Colorado River in western Lampasas County has ancestral Caddo ceramic vessel sherds (Field 1956:168 and Plate 21d-e), although the actual number of sherds was not stated. These sherds are from post-A.D. 1400 Frankston phase vessels of the types Bullard Brushed, Killough Pinched, and Poynor Engraved. The Poynor Engraved rim sherd has a loop handle (Field 1956:Plate 21e), an unusual feature in Poynor Engraved vessels.

\section{Llano County}

\section{Fall Creek (41LL4)}

Jackson (1938:110-111) identified 64 ceramic sherds from the Fall Creek site, being found in two burned rock mounds and two middens; most of the sherds were recovered from midden no. 2 ( $\mathrm{n}=37$ ). Jackson (1938:111) considered 15 of the sherds to have originated in East Texas, and these have brushed, appliqued, and engraved decorative elements (Jackson 1938:Plate XXII), including one Historic Caddo Patton Engraved sherd (Jackson 1938:Plate XXII:3). 
In addition to Toyah phase Leon Plain sherds, Midden 1 at the Fall Creek site (Site No. 3) also contains three ancestral Caddo vessel sherds. The first is a bone-tempered body sherd with parallel brushing marks, likely from a Bullard Brushed vessel made by a Caddo potter in the Neches, Angelina, or mid-Sabine River basins in East Texas (see Perttula 2015a:Figure 11). A grog-tempered body sherd has parallel incised lines (INAA, UT00290), and a grog-bone-tempered body sherd has a straight appliqued ridge (INAA, UT00289).

\section{$41 L L 76$}

Ceramic vessel sherds from 41LL76 include sherds from Maydelle Incised (INAA, UT00348, grog-bone-tempered) (Figure 45) and Bullard Brushed types, and sherds from a linear punctated jar (Assad and Potter 1979:Figure 14a-b, f-g). Other sherds in the collections at TARL include a grog-bone-tempered body sherd with closely-spaced parallel engraved lines (INAA, UT00351), a grog-tempered body sherd with vertical brushing marks (INAA, UT00350), and a grog-bone-tempered body sherd with a row of tool punctations (INAA, UT00349). These kinds of decorations on ancestral Caddo pottery likely are associated with post-A.D. 1400 vessels manufacture by upper Neches River basin groups.

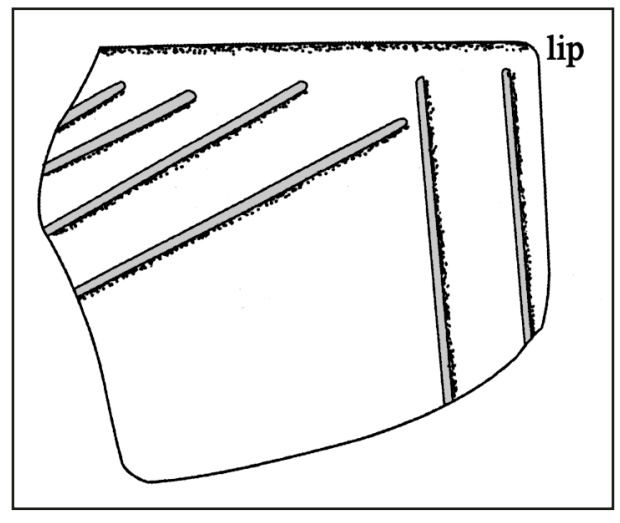

Figure 45. Decorative elements on Maydelle Incised rim sherd from 41LL76.

\section{LL413 (Charlotte Graham Collection)}

A grog-tempered body sherd (INAA, UT00181) with parallel brushing marks and rows of fingernail punctations pushed through the brushing is one of the two ancestral Caddo sherds from 41LL413. This sherd is likely from a Bullard Brushed jar. The second ancestral Caddo sherd from the site has incised chevron elements (Maydelle Incised) (Chuck Hixson, July 2017 personal communication). 41LL413 is on a high terrace of the Llano River.

\section{$41 L L 415$}

A Maydelle Incised jar rim sherd with hatched incised lines and a fingernail punctated strap handle has been recovered at this site on a small tributary to the Colorado River (Figure 46). The site has apparently been heavily damaged by golf course construction and the impounding of Lake LBJ (Charles Hixson, July 2017 personal communication).

\section{Mason County}

\section{Honey Creek (41MS32)}

The Honey Creek site is on a southward-flowing tributary to the Llano River (Black et al. 1997). The Toyah component there has a few sherds $(n=4)$ from an ancestral Caddo vessel; they were recovered from a nonmidden area at the southern end of the site (Black et al.

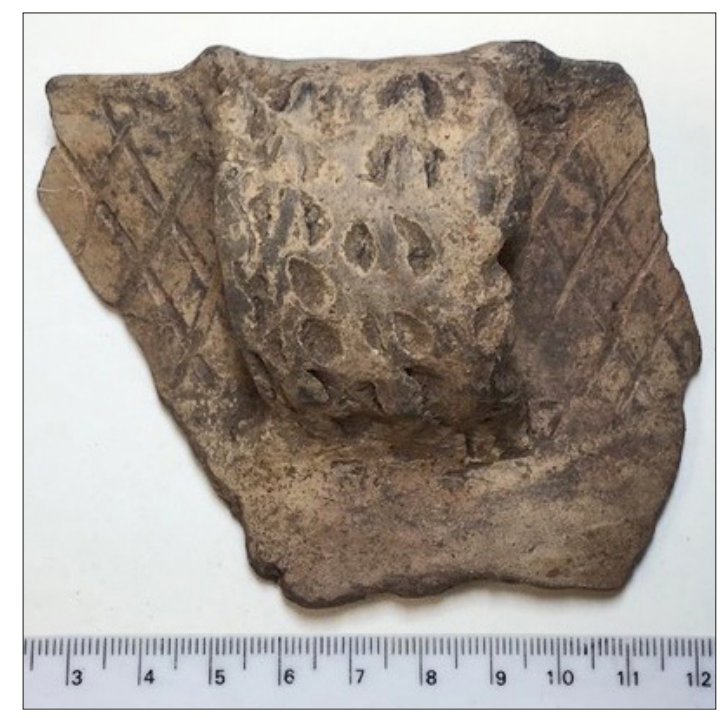

Figure 46. Maydelle Incised rim sherd from 41LL415. Photograph courtesy of Charles Hixson. 
1997:Figure 32; Ellis 1997:Table 87). The sherds have bone and grog temper, with hematite pieces also in the paste, and are described as having "a brushed/incised design...on the exterior surface of two sherds" (Ellis 1997:560). Ellis (1997:560) considers these sherds to be "part of a Caddo tradeware vessel," one that would have been made by a Caddo potter in East Texas sometime after ca. A.D. 1200, when brushed utility wares were commonly produced in several different East Texas locales.

\section{McLennan County}

\section{Gas Plant (41ML28)}

Ancestral Caddo ceramic sherds in the TARL collections from the Gas Plant site on the Brazos River are from grog-tempered plain $(n=8$, including INAA, UT00028) and decorated $(n=1)$ sherds. The one decorated sherd has cross-hatched incised decorative elements, and is likely from a Maydelle Incised vessel. Jensen (1967:45-49) indicates that the Gas Plant site was likely occupied by the Tawakoni or Waco peoples between the 1770 s and 1830 s.

\section{Baylor Site (41ML35)}

Excavations by Story and Shafer (1965) recovered 37 ceramic vessel sherds from the Baylor site at Waco Reservoir on the Brazos River. These included grog-tempered sherds from an Early Caddo period Weches Fingernail Impressed vessel (Story and Shafer 1965:Figure 23a-d), an incised-pinched bone-tempered vessel (Story and Shafer 1965:Figure 24a), sherds from an incised-punctated vessel (Story and Shafer 1965:Figure 24b-d), and sherds from a plain bottle (Story and Shafer 1965:Figure 24c-h). There also were seven plain sherds, one with grog temper and the other six with bone temper (Story and Shafer 1965:Figure 24i-k).

TARL sherds from the Baylor site analyzed by INAA include three samples from ancestral Caddo vessels: a plain grog-tempered body sherd (previously identified as incised-punctated, UT00031), an Early Caddo period Weches Fingernail Impressed grog-tempered body sherd (UT00029), and a grogtempered plain bottle sherd (UT00030). The bottle sherd has an exterior burnished surface.

Mehalchick and Kibler (2008:65-69 and Figure 5.11) also recovered a small number of grog and bone-tempered Caddo sherds from the Baylor site in later investigations, including grog-tempered $(n=11)$, bone-tempered $(n=1)$, grit-tempered $(n=1)$, grog-grit-tempered $(n=1)$, and grog-bone-tempered $(\mathrm{n}=1)$. The bone-tempered sherds have parallel incised lines, while others have pinching, fingernail punctations, and tool punctations. One sherd from a Weches Fingernail Impressed vessel indicates that these Caddo sherds were made in Early Caddo period times, from ca. A.D. 900-1200. Mehalchick and Kibler (2008:68-69) concluded that:

these sherds...must have come from East Texas. Conclusive evidence of this comes from a geochemical study of Caddo-style decorated ceramic sherds from other central Texas sites (Perttula et al. 2003). This study demonstrates that these sherds were not made from central Texas clays, thereby ruling out the possibility that Caddo potters moved to central Texas or that the Caddo transferred pottery styles to central Texas potters.

\section{Stone Site (41ML38)}

The Stone site is a late $18^{\text {th }}$ century (ca. A.D. 1770-1786) Tawakoni Wichita village on an alluvial terrace of the west side of the Brazos River across from the mouth of Aquilla Creek (Duffield and Jelks 1961:70-73; Jelks 1970; Smith 2000; Cook and Dunbar 2008; Turner-Pearson 2008). The Tawakoni 
headman was Chief Quiscat (Smith 2000:54). Remote sensing investigations indicate that the village had at least 75 circular structures arranged in rows and remnants of earthwork fortifications (Cook and Dunbar 2008:497 and Figure 7).

Frank Watt and Al Redder collected from the surface of the Stone site primarily from 1959-1962, after Edward B. Jelks had found the site in 1959 (Jelks 2017:1-2), but continued collecting there through the 1970s (Turner-Pearson 2008:566). The collected artifacts are now in the holdings of the Mayborn Museum Complex at Baylor University. Jelks (2017 personal communication) indicated that when he recorded the site, Frank Watt was unaware of it since he had been looking for sites on the east side of the Brazos River.

The ceramic sherds collected by Watt and Redder have been documented for this report. There are other ceramic sherd collections found by Walton Ballew at the site, as well as 556 ceramic sherds recovered in the 1999-2002 Baylor University Field Schools held at the site (Turner-Pearson 2008:Table 1). These sherds have not been studied, but Turner-Pearson (2008:573 and Figure 16) illustrates both Patton Engraved and Womack Engraved sherds in the Ballew Collection. Turner-Pearson (2008:573) also indicates that she identified sherds from bone-tempered Goliad Plain vessels in the collections, and there are a few such sherds (with handles) in the Watt-Redder collection.

There are 656 ceramic sherds in the Watt and Redder collections from the Stone site, including 94 sherds with decorative elements (Table 37). The plain to decorated sherd ratio (P/DR) of the assemblage is 5.97, indicating that plain vessels, or vessels with large undecorated portions, are quite common in this late $18^{\text {th }}$ century Wichita ceramic assemblage. This is particularly the case with the grog-bone-tempered and bone-tempered wares, as the P/DR for these wares ranges between 7.59-8.00, compared to P/DR values for the grog-tempered and shell-tempered wares that range from only 2.00-2.60.

Table 37. Ceramic sherds from the Watt and Redder collections from the Stone site (41ML38).

\begin{tabular}{lllllll}
\hline Ware & & \multicolumn{3}{c}{ Temper Categories } & B-H & Sh \\
\hline Plain & G & G-B & B & B-H & N \\
Utility & 70 & 220 & $267^{*}$ & 1 & 4 & 562 \\
A & 17 & 6 & 7 & - & - & 30 \\
B & - & - & 1 & - & - & 1 \\
B-I & 16 & 5 & 3 & - & - & 3 \\
I & - & 1 & 2 & - & - & 1 \\
P & 1 & - & - & - & - & 1 \\
Fine & - & - & 1 & - & - & 64 \\
E & 10 & 23 & 29 & - & 2 & 4 \\
E-RS & 1 & 17 & - & - & - & 1 \\
RS & 2 & 6 & 10 & - & 1 & 656 \\
\hline Totals & 97 & 249 & 303 & 1 & 6 & 19 \\
\hline
\end{tabular}

$\mathrm{G}=$ grog; $\mathrm{G}-\mathrm{B}=$ grog-bone; $\mathrm{B}=$ bone; $\mathrm{B}-\mathrm{H}=$ bone-hematite; $\mathrm{Sh}=$ shell

*includes three handle sherds and a pedestal leg sherd

A=appliqued; B=brushed; $\mathrm{B}-\mathrm{I}=$ brushed-incised; I=incised; P=punctated; E=engraved; E-RS=engraved-red-slipped; $\mathrm{RS}=$ red-slipped 
The sherds are from vessels tempered with a variety of inclusions, principally burned bone and grog. More than 84 percent of the sherds from the Stone site have burned bone aplastics, either as the sole temper (46.1 percent), or in combination with grog (38.1 percent); one sherd has burned bone and crushed hematite temper ( 0.2 percent). Vessels tempered solely with grog represent 14.8 percent of the assemblage, and 52.9 percent of all the sherds in the assemblage have grog temper as either the sole temper or in combination with bone (see Table 37). Sherds from shell-tempered vessels account for only 0.9 percent of the Stone site ceramics.

Ceramic vessels at earlier Wichita sites in the Arkansas River (Lasley Vore, see Odell 2002) and the Red River (Longest, see Bell et al. 1967; Beach 2015) were regularly tempered - if not almost exclusively at the Lasley Vore site and the Bryson-Paddock site (Hartley and Miller 1977) — with burned mussel shell, but by 1750 , a range of tempers were employed in vessel manufacture, including grog, bone, and shell. In Texas Wichita sites in the Brazos (Stone site) and Trinity (Vinson site) river basins that date between ca. 1760-1790, the ceramics found on them are primarily bone-tempered (Table 38), with a considerable decrease in the use of burned mussel shell as a temper. Grog-tempered ceramics are especially well represented at the Stone site, and these grog-tempered and grog-bone-tempered sherds are from East Texas Caddo ceramic vessels. The decorations on the bone-tempered and shell-tempered sherds in the assemblage (see Table 37) suggest that they also come from East Texas Caddo vessels. By ca. 1750, Wichita Indian peoples were relying on Caddo manufactured vessels obtained through French trade networks as well as copper kettles (see Beach 2015).

Table 38. Temper categories in Wichita Indian sites in Texas and Oklahoma.

\begin{tabular}{lccccccc}
\hline Site & Age & Grog & G-B & B & H & Sh & N \\
\hline $\begin{array}{l}\text { Arkansas River basin } \\
\text { Lasley Vore }\end{array}$ & $1719-1750$ & $*$ & - & $*$ & - & 99.7 & 3611 \\
Bryson-Paddock & $1719-1750 \mathrm{~s}$ & - & - & - & - & 95.4 & 867 \\
Red River basin & & & & & & & \\
Longest & $1750-1800$ & 6.0 & - & $* *$ & - & 18.7 & $134+$ \\
Trinity and Brazos River basins & $1760-1790$ & 4.0 & - & & & & \\
Vinson & $1770-1786$ & 14.8 & 38.0 & 46.1 & 0.2 & 0.9 & 655 \\
Stone & & & & & & & \\
\end{tabular}

$\mathrm{G}-\mathrm{B}=$ grog-bone; $\mathrm{B}=$ bone; $\mathrm{H}=$ hematite; $\mathrm{Sh}=$ shell

*Trace (Odell 2002)

**Present but not quantified

+does not include 48 sherds with sand in the paste at the Longest site (Bell et al. 1967:91-94) or the 112 sherds at the Vinson site that only had sand in the paste, and which may not have been a temper inclusion (Smith et al. 1993:110 and Table 3). Beach (2015:85) indicates that 101 sherds at Longest only had sand as a temper.

Each of the tempered wares at the Stone site have a different assortment of decorative methods and elements (Figures 47 and 48). The grog-tempered sherds are primarily from brushed jars (59.3 percent), and these were probably made by East Texas Caddo potters (Table 39). The only other utility ware is a rim sherd with diagonal incised lines, similar to Incised Sherd Group 1 at the Gilbert site (41RA13) in the upper Sabine River basin (Story et al. 1967:134), occupied between ca. A.D. 1720-1780 by Caddo peoples. Engraved wares from Womack Engraved vessels account for another 26 percent of the grog- 


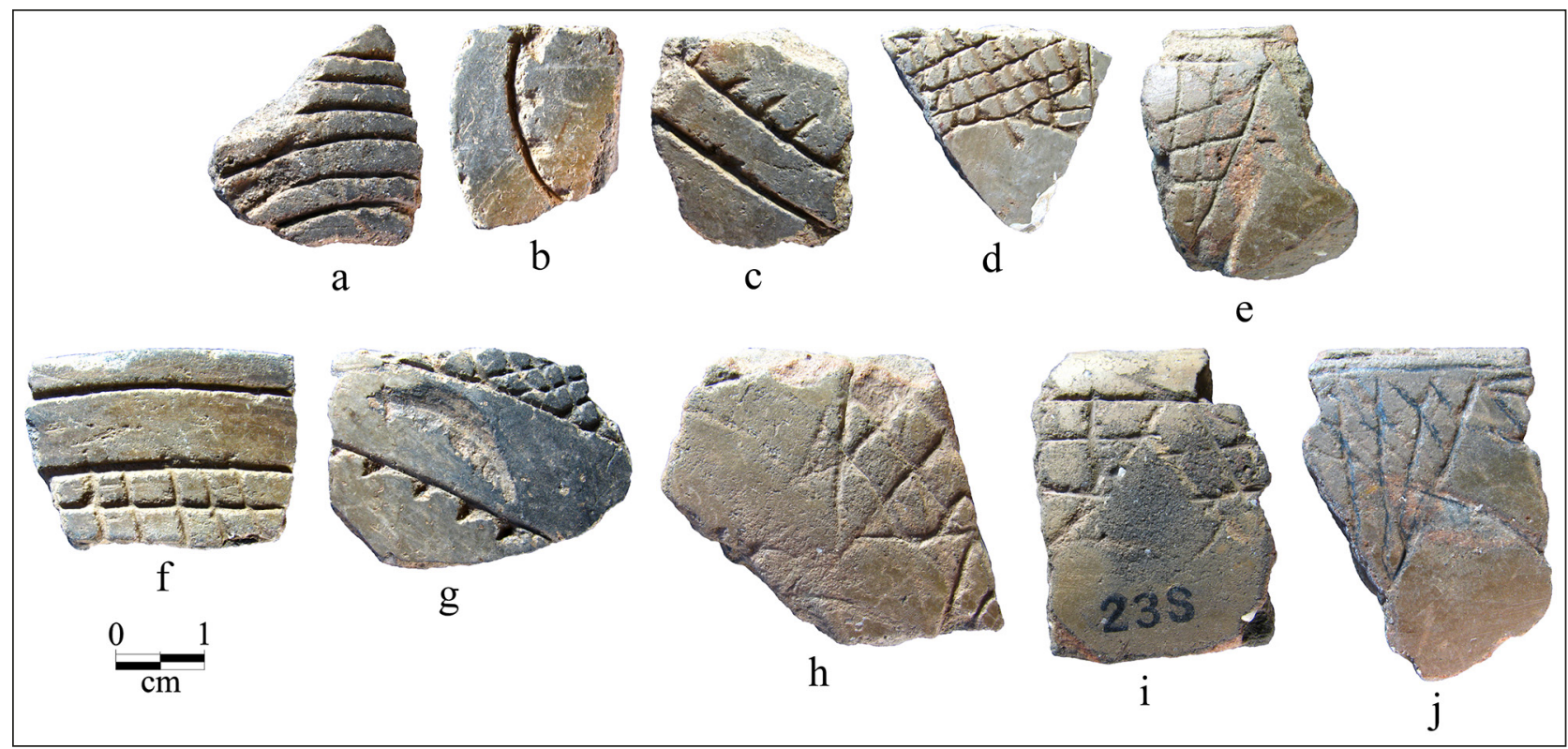

Figure 47. Womack Engraved sherds in the Watt-Redder collection from the Stone site (41ML38).

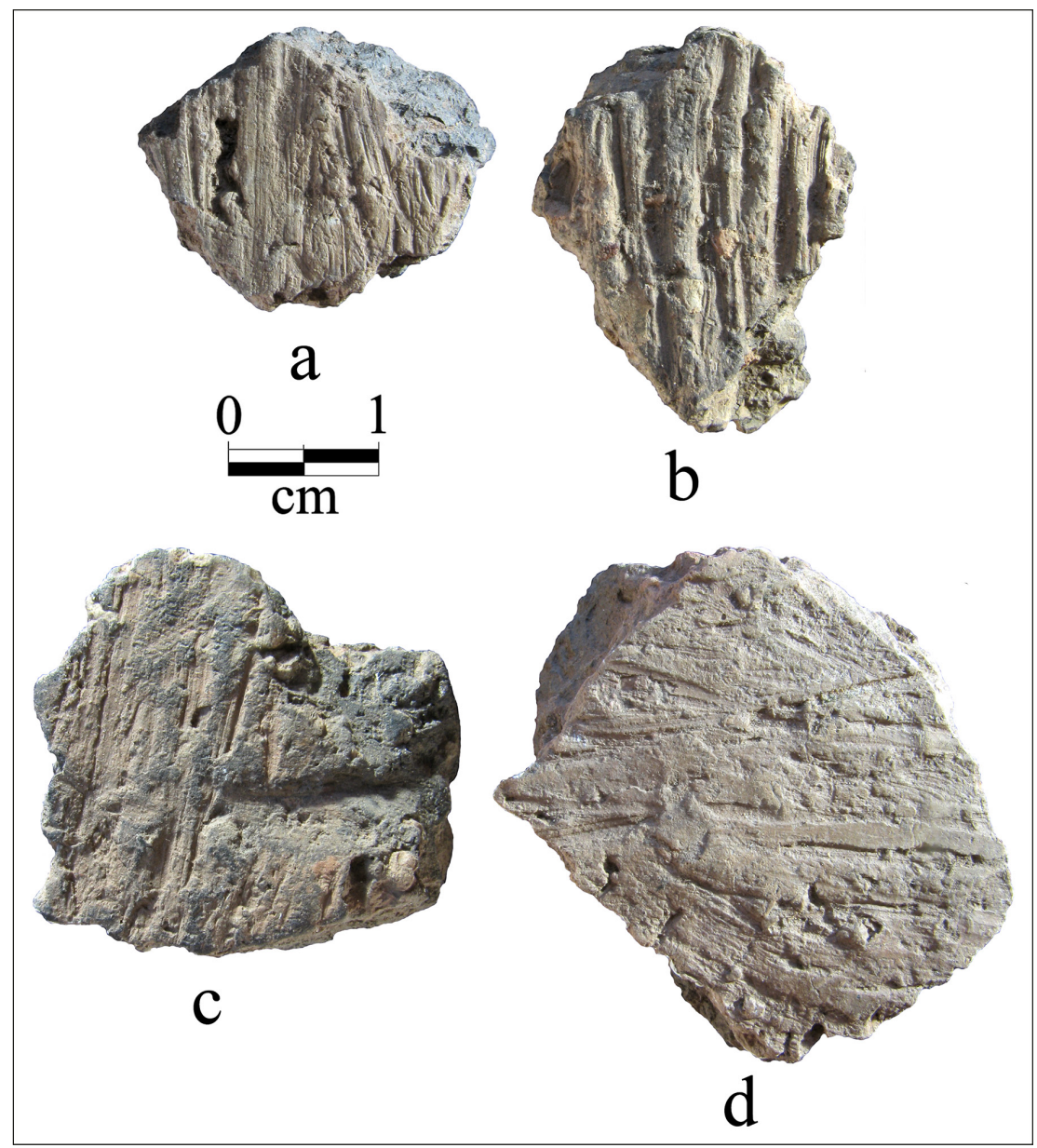

Figure 48. Brushed vessel sherds in the Watt-Redder collection from the Stone site (41ML38). 
tempered vessel sherds, and there is also one horizontal engraved body sherd from a red-slipped vessel. The Womack Engraved sherds are from Design A (Harris et al. 1965:Figure 6a; Story et al. 1967:Figure 49a) vessels, and the one sherd with a straight engraved line with tick marks is from a Patton Engraved vessel. About 7 percent of the decorated sherds are from vessels that have a red slip on their exterior surfaces; similar red-slipped sherds of uncertain type are present in the assemblage at the Longest site (Beach 2015:81), but not at the nearer Vinson site (see Smith et al. 1993).

Table 39. Decorative methods and elements on the decorated sherds from the Stone site ceramic assemblage.

\begin{tabular}{llll}
\hline Decorative method and elements & Rim & Body & $\mathrm{N}$ \\
\hline
\end{tabular}

\section{Grog-tempered}

Utility ware

Brushed

opposed brushed

overlapping brushed

parallel brushed

$\begin{array}{lll}- & 2 & 2 \\ - & 2 & 2 \\ - & 12 & 12\end{array}$

Incised

diagonal incised lines

Fine ware

Engraved

cross-hatched engraved zone

horizontal engraved line

straight engraved line

straight engraved line with tick marks

straight engraved line and triangle el.

Engraved-Red-slipped

horizontal engraved line-int. red slip

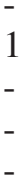

2

2

Red-slipped

ext. red-slipped

Sub-total, grog-tempered

\section{Grog-bone-tempered}

Utility ware

Brushed

parallel brushed

Brushed-Incised

parallel brushed-incised marks and lines

Fine ware

Engraved

cross-hatched triangular engraved zones

cross-hatched engraved zone 
Table 39. Decorative methods and elements on the decorated sherds from the Stone site ceramic assemblage, continued.

\begin{tabular}{|c|c|c|c|}
\hline Decorative method and elements & Rim & Body & $\mathrm{N}$ \\
\hline $\begin{array}{l}\text { cross-hatched engraved zone and scroll line with } \\
\text { tick marks }\end{array}$ & - & 1 & 1 \\
\hline curvilinear engraved line & - & 1 & 1 \\
\hline hatched engraved panel & - & 1 & 1 \\
\hline horizontal engraved lines below lip & 1 & - & 1 \\
\hline parallel engraved lines & - & 1 & 1 \\
\hline straight engraved line & - & 4 & 4 \\
\hline straight excised zone & - & 1 & 1 \\
\hline \multicolumn{4}{|l|}{ Red-slipped } \\
\hline ext. red-slipped & - & 4 & 4 \\
\hline int. red-slipped & - & 1 & 1 \\
\hline int./ext. red-slipped & - & 1 & 1 \\
\hline Subtotal, grog-bone-tempered & 5 & 24 & 29 \\
\hline
\end{tabular}

\section{Bone-tempered}

Utility ware

Appliqued

parallel appliqued ridges

1

Brushed

horizontal brushed

opposed brushed

parallel brushed

Brushed-Incised

parallel brushed-incised

Punctated

single fingernail punctation

Fine ware

Engraved

cross-hatched triangular zones

curvilinear-spiral engraved lines

curvilinear engraved line with tick marks

curvilinear engraved line

diagonal engraved line

excised tick marks

$1+$ horizontal engraved line (white pigment)

horizontal engraved line and cross-hatched zone

horizontal engraved line and triangle el.

horizontal-vertical engraved lines

opposed engraved lines

parallel engraved lines

parallel engraved lines, 1 with tick marks

straight engraved line

$\begin{array}{lll}1 & - & 1 \\ - & 1 & 1 \\ - & 1 & 1 \\ - & 1 & 1 \\ 1 & - & 1 \\ - & 1 & 1 \\ - & 1 & 1 \\ 1 & - & 1 \\ 1 & - & 1 \\ 1 & 1 & 2 \\ - & 2 & 2 \\ - & 2 & 2 \\ - & 1 & 1 \\ - & 3 & 3\end{array}$


Table 39. Decorative methods and elements on the decorated sherds from the Stone site ceramic assemblage, continued.

\begin{tabular}{|c|c|c|c|}
\hline Decorative method and elements & Rim & Body & $\mathrm{N}$ \\
\hline \multicolumn{4}{|l|}{ Red-slipped } \\
\hline ext. red-slipped & - & $7 *$ & 7 \\
\hline int./ext. red-slipped & - & 3 & 3 \\
\hline Subtotal, bone-tempered & 6 & 30 & 36 \\
\hline \multicolumn{4}{|l|}{ Shell-tempered } \\
\hline \multicolumn{4}{|l|}{ Fine ware } \\
\hline \multicolumn{4}{|l|}{ Engraved } \\
\hline broad curvilinear excised line & - & 1 & 1 \\
\hline $\begin{array}{l}\text { Red-Slipped } \\
\text { ext. red-slipped }\end{array}$ & - & 1 & 1 \\
\hline Subtotal, shell-tempered & - & 2 & 2 \\
\hline Totals & 13 & 80 & 93 \\
\hline
\end{tabular}

*includes two bottle sherds

The decorated grog-bone-tempered vessel sherds from the Stone site have a high proportion of engraved wares (58.6 percent). These include a number from Womack Engraved Design A and B vessel sherds (see Figure 47; see also Story et al. 1967:Figure 49b). Interior and/or exterior red-slipped vessels account for another 20.7 percent of the grog-bone-tempered decorated sherds (see Table 39). The remainder of the decorated sherds (20.7 percent) in this group are from jars with brushed and brushedincised marks and lines.

The bone-tempered wares from the Stone site are dominated by engraved fine wares (52.8 percent) and red-slipped sherds (27.8 percent) (see Table 39). These are primarily from Womack Engraved, Design A and B vessels (see Figure 47), but one sherd with parallel engraved lines and tick marks is likely from a Patton Engraved vessel. Brushed and brushed-incised vessel sherds account for 13.9 percent of the bone-tempered decorated sherds at the site. The one appliqued sherd has parallel appliqued ridges, and may be from a Cass Appliqued jar (see Story et al. 1967:144). The single bone-tempered punctated body sherd has only a single fingernail punctation.

One of the two shell-tempered sherds with decorative elements in the Stone site collection has a broad curvilinear engraved line, and may be from a Design C Womack Engraved vessel (see Harris et al. 1965:Figure 6c; Story et al. 1967:Figure 49c). The other decorated shell-tempered sherd has an exterior red slip, and may be from a Clement Redware vessel (see Flynn 1976), made by Late and Historic Caddo potters of the McCurtain phase living along the mid-Red River basin in East Texas and southeast Oklahoma, or later Womack phase peoples with settlements on the Red River and the upper Sabine River basin.

There is also a collection of sherds from the Stone site in the TARL holdings; these apparently were collected by Frank Watt at Dee Ann Story's request and subsequently donated to TARL in the mid-1960s. In addition to Goliad plain handle sherds $(n=7)$, there are ancestral Caddo sherds from grog, grog-bone, 
and bone-tempered vessels (Table 40) as well as an assortment of ceramic elbow pipe sherds of likely Caddo manufacture, and one ceramic ear plug.

Table 40. Ceramic wares in the TARL collection from the Stone site (41ML38).

\begin{tabular}{lllll}
\hline Ware & Grog & Grog-Bone & Bone & N \\
\hline Plain ware & 32 & 21 & 70 & 123 \\
Utility ware & 6 & - & 2 & 8 \\
Fine ware & 4 & 2 & 1 & 7 \\
\hline Totals & 42 & 23 & 73 & 138 \\
\hline
\end{tabular}

Sherds with bone temper comprise 52.9 percent of this particular assemblage at the site, along with another 16.7 percent that are from grog and bone-tempered vessels. Only 30.4 percent of the sherds - but most of the decorated pieces - are from grog-tempered vessels.

Among the utility wares in this collection is a grog-tempered body sherd with parallel brushed marks and overlying parallel incised lines, most likely from an Historic Caddo Spradley Brushed-Incised vessel; these vessels were made by Caddo potters in the Neches-Angelina river basins in East Texas (see Marceaux 2011). Three grog-tempered body sherds and one bone-tempered body sherd from Bullard Brushed vessels have parallel brushing marks, while grog-tempered body $(n=1)$ and rim sherds $(n=1)$ have either overlapping or horizontal brushing marks on jars. Another body sherd, but from a bonetempered vessel, has a set of zig-zag incised lines.

The fine ware sherds in the TARL collection from the Stone site have engraved $(n=3)$ and red-slipped $(n=4)$ decorative elements. One engraved sherd has a single curvilinear engraved line, another has horizontal and vertical engraved lines, and the third has a straight engraved line with excised tick marks on both sides of the engraved line; this decorative element may be related to the ticked engraved lines on Patton Engraved vessels made by Caddo potters living in the Neches-Angelina river basin after ca. A.D. 1680. Two of the red-slipped sherds have a slip on both interior and exterior vessel surfaces, and the two others have a red slip only on their exterior surface.

Taking the Watt/Redder and TARL collections from the Stone site together as one assemblage for purposes of comparison with other assemblages with decorated ancestral Caddo pottery, the 109 decorated sherds include utility wares $(n=38,34.9$ percent) and fine wares $(n=71,65.1$ percent). The utility wares are from vessels with appliqued $(n=1)$, brushed $(n=30)$, brushed-incised $(n=4)$, incised $(n=2)$, and punctated $(n=1)$ decorative elements. The fine wares are from vessels that have engraved $(n=47)$, engraved-red-slipped $(n=1)$, and red-slipped $(n=23)$ vessels.

Sherds from ceramic elbow pipes are relatively common in the TARL collections from the Stone site $(n=10)$. These pipes are either tempered with grog $(n=6)$ or bone $(n=2)$; two other pipe sherds have been carved from a tuffaceous stone, and have parallel lines carved into two sides of the pipe stem. These elbow pipes have flat lips, burnished to polished bodies, and have a distal knob on the stem (see Story 1985:Figure 4a). The most complete elbow pipe in the TARL collection has a flat lip and a polished exterior surface; the stem is $43.0 \mathrm{~mm}$ in length, and the lip is $6.6 \mathrm{~mm}$ thick. The interior and exterior stem orifice diameters are $11.8 \mathrm{~mm}$ and $24.2 \mathrm{~mm}$, respectively. 
The ceramic ear plug in the TARL collection from the Stone site is grog-tempered, and flattened at one end. The ear plug is $13.0 \mathrm{~mm}$ in diameter, with flat ends, and approximately $14.1 \mathrm{~mm}$ in height. Very similar ear plugs have been documented from late $17^{\text {th }}$ century burial features at the H. R. Taylor site (41HS3) in the Big Cypress Creek basin in East Texas (Perttula 2018:Figure 426c).

In a broader comparative sense, in the ca. A.D. 1719-1750 Wichita occupation at the Lasley Vore site, sherds from vessels with incised or punctated decorative elements comprise more than 91 percent of the decorated sherd sample (see Odell 2002), with no red-slipped sherds and only small amounts of brushed pottery (Table 40); this pottery (Deer Creek Brushed) is on vessels manufactured with shell temper (Odell 2002:194). At the generally contemporaneous Bryson-Paddock site, however, simple stamped sherds from shell-tempered vessels comprise about 87 percent of the decorated sherds (Hartley and Miller 1977:62). Brushed (Deer Creek Brushed) and incised (Emory Punctated-Incised) shell-tempered sherds account for another 2 percent of the decorated sherds. The remaining 11 percent of the decorated sherds are from Womack Engraved vessels (Hartley and Miller 1977:74-75).

After A.D. 1750, the assemblage at the Longest site is dominated by engraved sherds from Womack Engraved and Patton Engraved vessels (Bell and Bastian 1967). Both the post-A.D. 1760-1790 and ca. A.D. 1770-1786 components at the Vinson and Stone sites have considerable proportions of bone and/ or grog-tempered brushed pottery that was made by Caddo peoples (Table 41). Womack Engraved and Patton Engraved remain the principal fine wares in both components. Most distinctive is the grog, bone, and shell-tempered sherds from red-slipped vessels only at the Stone site; the other $18^{\text {th }}$ century Wichita sites do not have red-slipped vessels, although Drass (February 2017 personal communication) has noted a single red-slipped and simple stamped sherd in the Longest site ceramic assemblage.

Table 41. Decorative methods represented in $18^{\text {th }}$ century Wichita sites in Oklahoma and Texas.

\begin{tabular}{lllll}
\hline $\begin{array}{l}\text { Decorative } \\
\text { method }\end{array}$ & Lasley Vore & Longest & Vinson & Stone \\
\hline $\begin{array}{l}\text { Appliqued } \\
\text { Brushed }\end{array}$ & - & - & - & 1.1 \\
Brushed-Incised & $3.2^{*}$ & 10.3 & 47.5 & 25.8 \\
Incised & - & - & - & 3.2 \\
Punctated & 63.5 & + & 23.7 & 1.1 \\
Stamped & 27.8 & - & 6.6 & 1.1 \\
Engraved & 0.8 & - & - & - \\
Red-slipped & 4.8 & - & - & 22.4 \\
- & - & 29.7 & 76 & 20.4 \\
Totals & 126 & & & 93 \\
\hline
\end{tabular}

*percentage

$+=$ Vessel 1, cf. Emory Punctated-Incised

Beach (2015:86) has noted that by the 1750s the Wichita living at the Longest site (34JF1) on the Red River "were no longer depending solely upon their own vessels to cook and store foods as copper kettles and Caddo vessels were being widely used instead." The number of Caddo ceramic vessel sherds at the Stone site indicates this is also the case later in the $18^{\text {th }}$ century, though, given the number of vessel sherds in the collection, Caddo vessels were apparently rather regularly obtained by the Wichita living on the Brazos River through their Caddo and French trade networks. Beach (2015:92) questions the origin of the Caddo ceramic vessels at the Longest site, but concedes that trade is one possibility; she suggests also that Caddo women may have been "marrying into the Wichita village." Since the Caddo have a matrilineal social organization where the women remain in their own villages and communities 
and the husbands would move to these villages and communities, for Caddo women to be living in Wichita villages would be likely only in cases where Caddo families were actually residing in the Wichita villages. Thus, it seems unlikely that marriage would account for the presence of Caddo ceramic vessels on mid- to late $18^{\text {th }}$ century Wichita villages.

\section{Clark Site (41ML39)}

The Clark site is located on the Brazos River about $1.2 \mathrm{~km}$ below its confluence with Aquilla Creek, a southward-flowing tributary of the river, and ca. $10 \mathrm{~km}$ upstream from the city of Waco. The site consists of a buried midden deposit (ca. 50-95 cm bs) in an alluvial terrace of the Brazos (Watt 1965:99). The Central Texas Archeological Society completed excavations at the site in 1955, and recovered a small number of arrow points of the Perdiz type $(n=20)$ and 63 ceramic sherds (Watt 1965:Figures 3a-n and $5 \mathrm{c}-\mathrm{h}$ ). The three decorated sherds in the collection have either diagonally opposed incised line or an incised-punctated rim sherd (Watt 1965:Figure 5c-e), and may be from Canton Incised vessels. A single uncalibrated radiocarbon date of A.D. $1275 \pm 150$ was obtained on charcoal from a hearth (Watt 1978:121); most of the pottery sherds recovered from the site came from excavations near to the hearth.

The Frank Watt sherd collection from the Clark site at the Mayborn Museum Complex has 55 ceramic sherds from ancestral Caddo vessels (Table 42). Most notably, the decorated sherds are from vessels typically found in Sanders phase (ca. A.D. 1200-1400), McCurtain phase (ca. A.D. 1400-1680), and Womack phase (post-A.D. 1680) sites along the Red River, rather than from Caddo potters living in communities along the Neches River in East Texas.

Table 42. Frank Watt collection from the Clark site (41ML39) in the Mayborn Museum Complex holdings.

\begin{tabular}{llllll}
\hline Ware & $\begin{array}{l}\text { grog- } \\
\text { tempered }\end{array}$ & $\begin{array}{l}\text { grog-bone } \\
\text { tempered }\end{array}$ & $\begin{array}{l}\text { bone- } \\
\text { tempered }\end{array}$ & $\begin{array}{l}\text { shell- } \\
\text { tempered }\end{array}$ & $\mathrm{N}$ \\
\hline Plain & 33 & 11 & 2 & - & 46 \\
Utility & 3 & - & - & 2 & 5 \\
I & 2 & - & - & - & 2 \\
P-A & - & - & - & 1 & 1 \\
LN & 1 & - & - & - & 1 \\
NB & - & - & - & 1 & 4 \\
Fine & 3 & - & - & $1 * *$ & 4 \\
E & $3 *$ & 11 & 2 & 3 & 55 \\
\hline Totals & 39 & &
\end{tabular}

I=incised; P-A=punctated-appliqued; LN=lip notched; NB=neck banded; E=engraved

*also one with an interior and exterior red-slipped surface

**also one with an interior and exterior red-slipped surface

About 91 percent of the ceramic sherd assemblage comes from vessels tempered either solely with grog or with grog and bone temper (see Table 42). One of the plain rim sherds (Figure 49c) may be from a Late Caddo period (dating after ca. A.D. 1500-1550) Simms Plain vessel with a very narrow and inverted rim (cf. Suhm and Jelks 1962:139); others have more direct profiles (Figure 49i-j). Only 3.6 percent of the sherds are from bone-tempered vessels, but another 20 percent have both grog and bone temper inclusions. More than 5 percent of the sherds are from shell-tempered vessels; shell-tempered ceramic sherds are rather uncommon in Central Texas ceramic assemblages. 


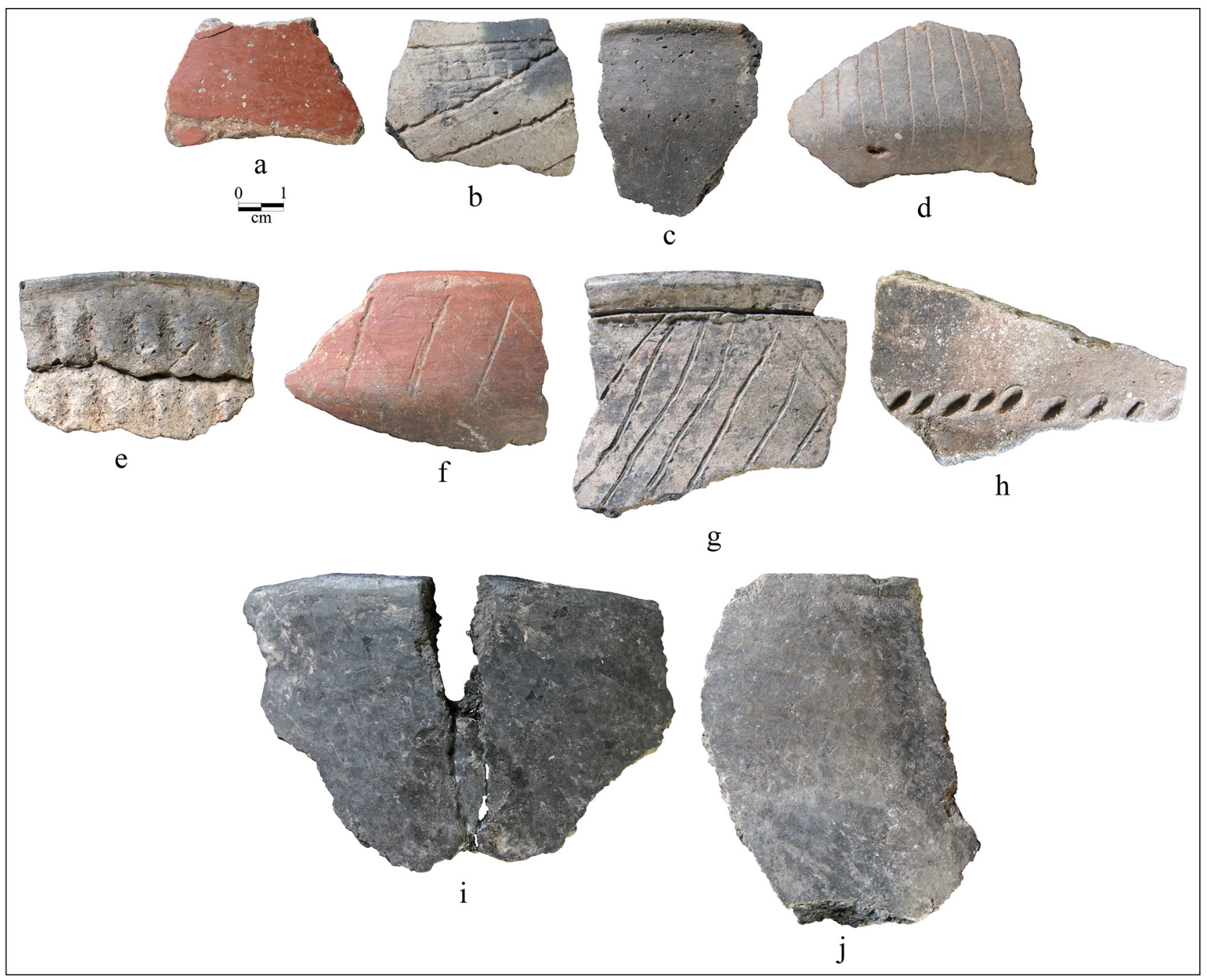

Figure 49. Selected decorated sherds from the Clark site in the Frank Watt collections.

The decorated sherds in this Clark site assemblage are divided between utility ware $(n=5)$ and fine ware $(n=4)$. The utility wares include a grog-tempered lip notched rim, a grog-tempered rim with diagonal opposed incised lines (see Figure 49g), and another grog-tempered rim with diagonal incised lines. The first shell-tempered rim sherd is from a Nash Neck Banded jar, of Late Caddo age and McCurtain phase affiliation (see Figure 49e), and the other is a body sherd from an Emory PunctatedIncised jar; this type is commonly present in both post-A.D. 1550 and post-A.D. 1680 mid-Red River components. The sherd has a tool punctated row at the rim-body juncture and a diagonal appliqued ridge on the vessel body (see Figure 49h).

Two of the engraved fine ware sherds are from Middle Caddo period Sanders Engraved carinated bowls with either cross-hatched engraved lines, or an engraved triangle filled with vertical engraved lines (see Figure 49d); one of these sherds has a red slip on both interior and exterior vessel surfaces (see Figure 49f). A shell-tempered body sherd is from a Late Caddo period Avery Engraved vessel with opposed engraved lines; this sherd also has a red slip on both vessel surfaces (see Figure 49a). The last Caddo fine ware sherd in this Watt collection is a grog-tempered rim from a post-A.D. 1680 manufactured Womack Engraved vessel. Such sherds are common in $18^{\text {th }}$ century Wichita sites in the Waco area (see discussion of the Stone site ceramics [41ML38]). This rim has a slanting engraved scroll element and a cross-hatched triangle element under the lip (see Figure 49b). 
There is a small collection of ceramic artifacts from the Frank Watt collection in the holdings of the Texas Archeological Research Laboratory at the University of Texas at Austin (TARL). This consists of 19 plain or decorated sherds from grog- or bone-tempered vessels (Table 43). Many of the plain sherds have burnished surfaces.

Table 43. Clark site (41ML39) ceramic artifacts in TARL collections.

\begin{tabular}{llll}
\hline Ware & grog-tempered & bone-tempered & N \\
\hline Plain Ware & & & 1 \\
plain rim & - & 7 & 11 \\
plain body & 4 & - & 1 \\
base & 1 & & \\
Utility Ware & 3 & 1 & 4 \\
Brushed & - & 1 & 1 \\
Incised & - & 1 & 1 \\
Incised-Punctated & 8 & 11 & 19 \\
\hline Totals & & & \\
\hline
\end{tabular}

About 58 percent of the sherds in this small collection are from bone-tempered vessels, and the remainder are from grog-tempered vessels. The one plain rim has a direct or vertical profile and a rounded lip.

Four of the decorated sherds are from brushed utility ware vessels, including a rim (direct profile and a rounded, exterior folded lip) with horizontal and vertical opposed brushing marks (Figure 50a). The occurrence of brushed ceramic vessel sherds is consistent with the one radiocarbon date from the site. The one incised sherd is from the body of a vessel and has a set of parallel incised lines. The incised-punctated rim sherd (direct profile and a rounded lip) is likely from a Maydelle Incised jar. It has diagonal incised triangle elements filled with rows of circular punctations (Figure 50b).

\section{Cement Hill (41ML43)}

The Cement Hill site is on an upland landform marked by the Austin Chalk Escarpment west of the Brazos River and ca. 1 mile from the South Bosque River (Watt 1953:73). Watt had recovered about 100 ceramic vessel sherds from the site, including several that were engraved $(n=2)$ and had a red slip, or were simply red-slipped $(n=3)$. Others were undecorated rim sherds $(n=5)$; one rim had a horizontal incised line below the lip; four had fingernail punctations; and five sherds were from Bullard Brushed vessels (Watt 1953:75 and Figure 22:1-7). Watt also mentioned the recovery of three probable Leon Plain sherds, as these were not incised, had a reddish color, and had "heavy bone temper inclusions" (Watt 1953:75). 
The most intriguing ceramic find reported by Watt at the Cement Hill site was an almost complete Hood Engraved bowl, with the accompanying effigy broken off some time prior to its discovery (Figure 51; see also Watt 1953:Figure 22B). the vessel was $12.7 \mathrm{~cm}$ in diameter and had horizontal and dipping engraved lines around the vessel; it was also red-slipped. Hood Engraved effigy vessels are concentrated in post-A.D. Caddo sites in several parts of the upper Neches River basin (Perttula 2011:Figure 6-67), and were most commonly used as mortuary offerings between ca. A.D. 1400-1480, although they continued to be made in the Historic Allen phase. The Hood Engraved vessel from the Cement Hill site is a var. Hood bowl: they have effigy heads (usually a bird or a duck) and tab tails, as well as broad horizontal engraved lines (usually three lines) on the rim (Perttula 2011:271).

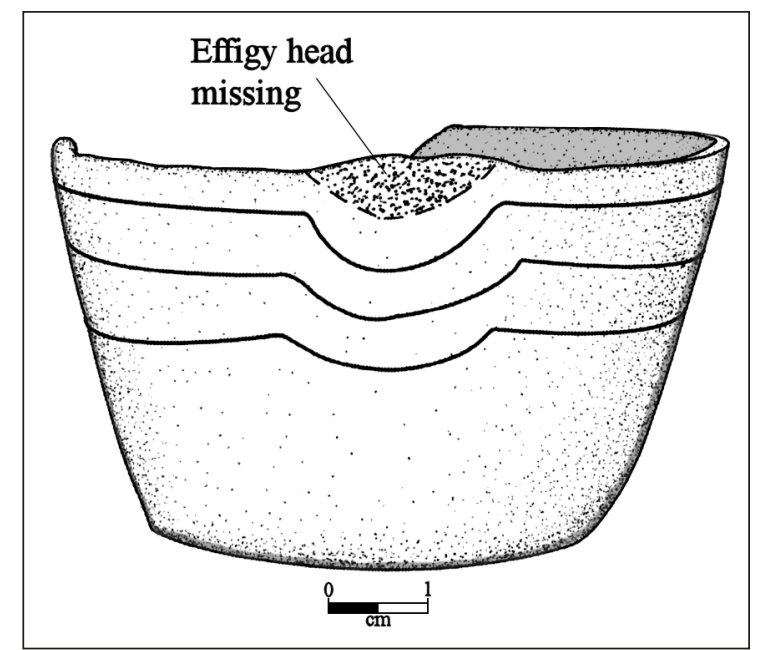

Figure 51. Decorative elements on Hood Engraved, var. Hood bowl from the Cement Hill site.

\section{Chupik (41ML44)}

The Chupik site is located on an alluvial knoll in the Brazos River floodplain, a few km north of the confluence of the Brazos River and Aquilla Creek (Figure 52). Substantial numbers of ceramic sherds $(n=700)$ have been collected from the site by Frank Watt (1941a, 1953), and a much larger ceramic sherd assemblage was recovered from the site during the 1972 University of Texas (UT) Field School (Dillehay 1972; Locke 1975).

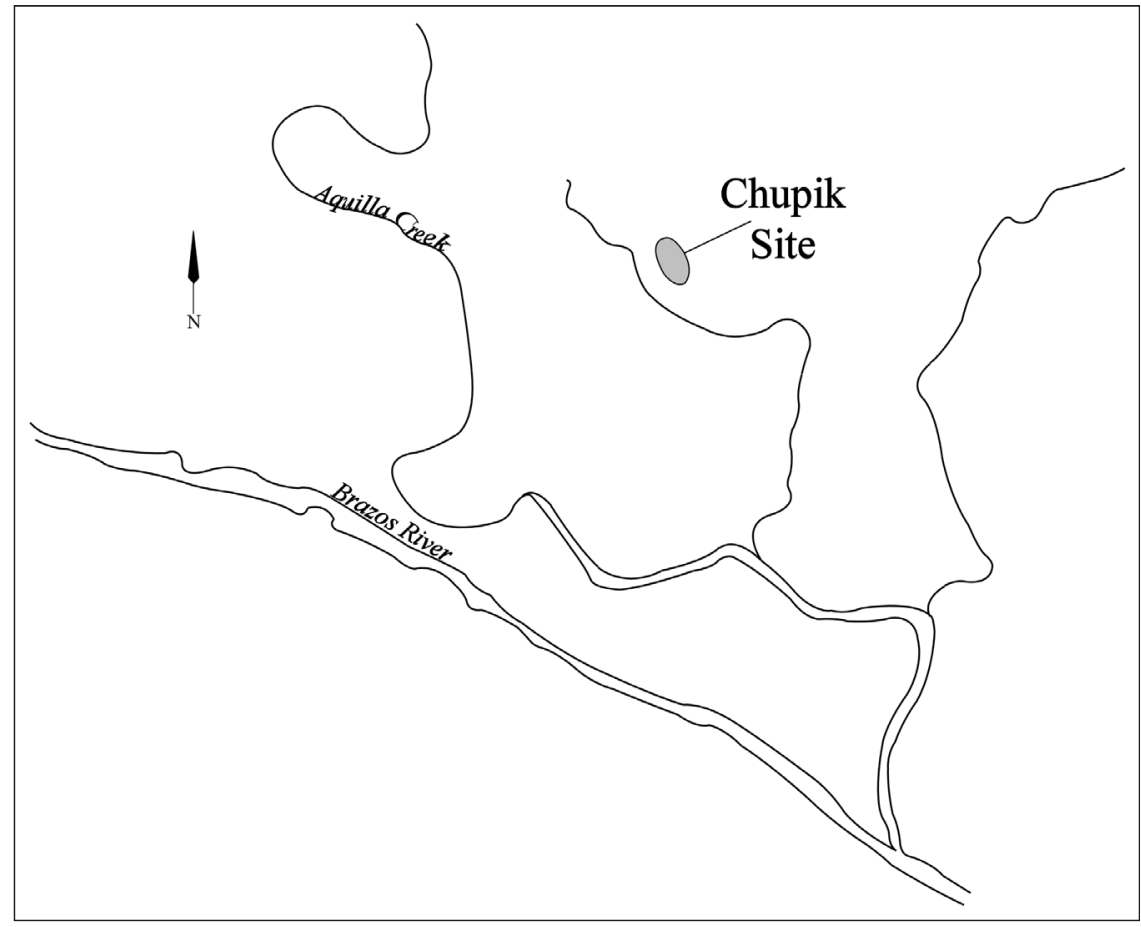

Figure 52. Location of the Chupik site (41ML44) in the Brazos River floodplain, based on Gholson 7.5' USGS topographic quadrangle. 
The Watt collection from the Chupik site included 550 plain body sherds and 150 decorated rim and body sherds (Watt 1953:73). The decorated sherds are from Pennington Punctated-Incised, Hickory Engraved, Davis Incised, Dunkin Incised, and Weches Fingernail Impressed, var. Weches vessels, and there are other sherds with incised or punctated decorative elements (Watt 1953:Figures 21a-b and 22a). A few of the sherds illustrated by Watt (1953:Figure 22:1, 10,14, and 22) are stylistically similar to Late Caddo period, Frankston phase Poynor Engraved and Bullard Brushed types.

During the UT Field School investigations at the Chupik site, nine different aboriginal ceramic sherd clusters were recognized across the knoll (Figure 53). These clusters cover a ca. 80 x $90 \mathrm{~m}$ area and are arranged in a large circle, with seven of the ceramic sherd clusters on the perimeter of the circle, an eighth on another knoll just to the east, and the ninth in the center of the circular clusters of ceramic sherds. Several of the ceramic clusters at the northern and southern ends of the site are associated with significant amounts of animal bone, and these clusters probably mark trash midden deposits. The smaller ceramic clusters on the northern, western, and eastern portions of the site may mark structure locations and/or outside activity areas. It is clear that the Chupik site has a significant residential component. In fact, Newell and Krieger (1949:195) had suggested that the Chupik site was am Early Caddo period village of Alto focus [now Alto phase) peoples.

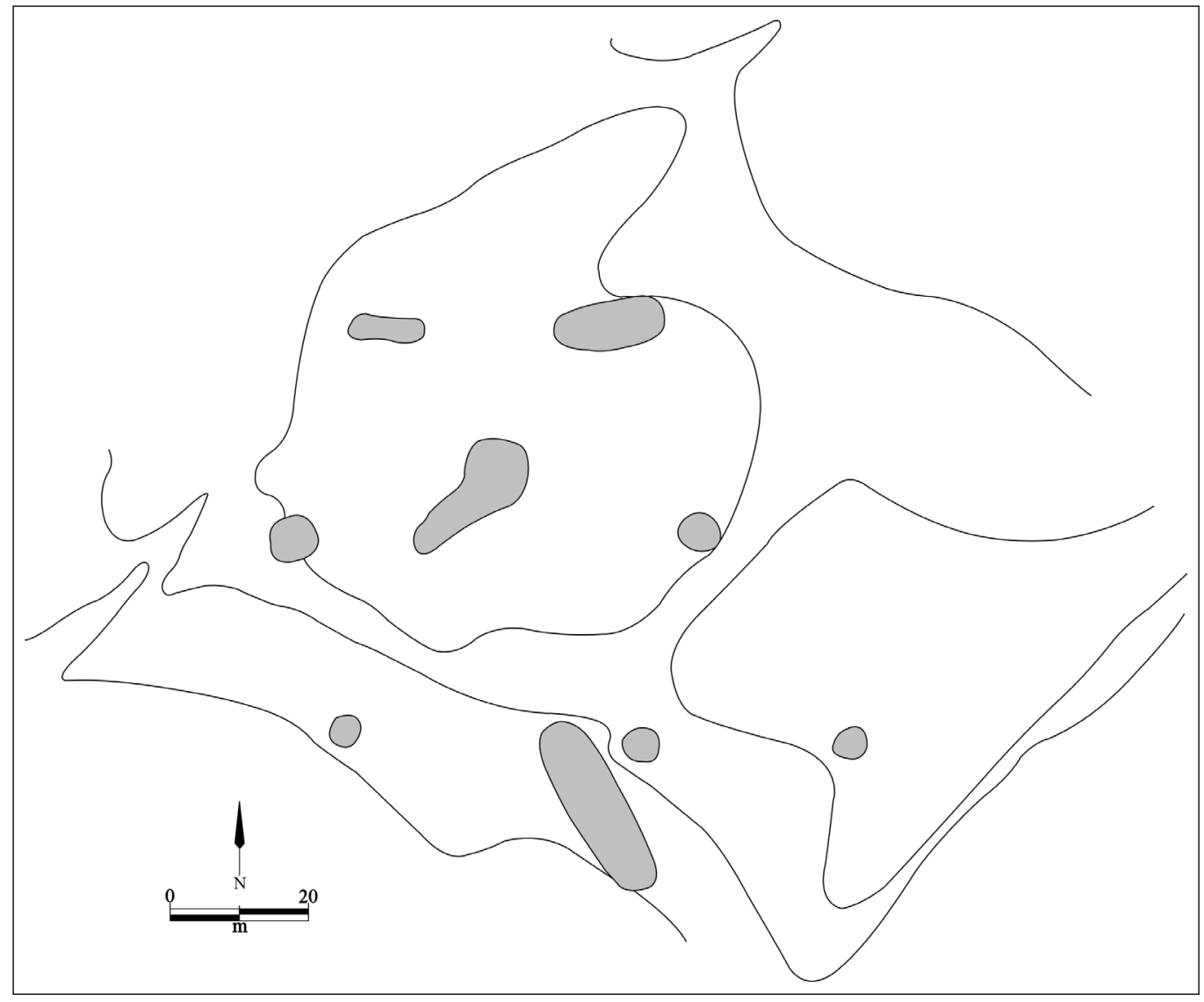

Figure 53. Ceramic artifact clusters at the Chupik site (41ML44). 
The assemblage of sherds from the site are almost exclusively from grog- or bone-tempered vessels (Table 44); one sherd has a sandy paste and may be from a Woodland period (ca. 500 B.C.-A.D. 800) Goose Creek Plain, var. unspecified vessel (see Story 1990a). About 83 percent of the sherds are from grog-tempered vessels, and about 17 percent of the sherds are from bone-tempered vessels. The highest proportion of bone temper use is in the fine wares (26.6 percent) from the Chupik site.

Table 44. Ceramic sherds from the Chupik site in TARL collections.

\begin{tabular}{|c|c|c|c|c|}
\hline Ware & grog-tempered & bone-tempered & $\mathrm{SP}$ & $\mathrm{N}$ \\
\hline \multicolumn{5}{|l|}{ Plain Ware } \\
\hline plain rim & 42 & 12 & - & 54 \\
\hline plain body & 714 & 135 & - & 849 \\
\hline base & 62 & 16 & - & 78 \\
\hline Subtotal, Plain Ware & 818 & 163 & - & 981 \\
\hline \multicolumn{5}{|l|}{ Utility Ware } \\
\hline Brushed & - & 3 & - & 3 \\
\hline Brushed-Incised & 1 & - & - & 1 \\
\hline Incised & 135 & 28 & - & 163 \\
\hline Incised-Punctated & 31 & 7 & - & 38 \\
\hline Punctated & 171 & 33 & 1 & 205 \\
\hline Subtotal, Utility Ware & 338 & 71 & 1 & 410 \\
\hline \multicolumn{5}{|l|}{ Fine Ware } \\
\hline Engraved & 55 & 21 & - & 76 \\
\hline Red-Slipped & 3 & - & - & 3 \\
\hline Subtotal, Fine Ware & 58 & 21 & - & 79 \\
\hline Totals & 1214 & 255 & 1 & 1470 \\
\hline
\end{tabular}

Note: this does not include four decorated sherds that were submitted for INAA and petrographic analysis from the site (Perttula et al. 2003:13-14 and Figure 3).

About 33 percent of the sherds in the collection have decorative elements, and the plain to decorated sherd ratio is 2.0. Almost 84 percent of the sherds with decorative elements in the Chupik site ceramic assemblage are from utility wares (i.e., vessels with wet paste decorations), and sherds from fine ware vessels (decorated after the vessel was leather-hard or after firing) comprise 16.2 percent of the sample of decorated sherds. Furthermore, approximately 77 percent of the rim sherds in the assemblage $(n=52)$ are from utility wares, and 23 percent are from fine wares. Both proportions indicate that sherds from utility ware vessels overall are by far the most common kind of decorated vessel sherds in the assemblage.

A total of 50 percent of the utility ware sherds are from vessels with punctated decorative elements (Table 45). Sherds from incised vessels account for 39.8 percent of the utility wares, followed by sherds with incised-punctated decorative elements ( 9.3 percent). Sherds from brushed ( 0.7 percent) and brushedincised ( 0.2 percent) elements comprise only approximately 1 percent of the decorated sherd assemblage. 
Table 45. Decorative methods and elements in utility ware sherds from the Chupik site (41ML44).

\begin{tabular}{|c|c|c|c|}
\hline Method/Element & Rim & Body & $\mathrm{N}$ \\
\hline Brushed & & & 3 \\
\hline opposed brushing marks & - & 1 & 1 \\
\hline parallel brushing marks & - & 2 & 2 \\
\hline Brushed-Incised & & & 1 \\
\hline $\begin{array}{l}\text { curvilinear brushed zone and } \\
\text { parallel incised lines }\end{array}$ & - & 1 & 1 \\
\hline Incised & & & 163 \\
\hline curvilinear lines & - & 2 & 2 \\
\hline $\begin{array}{l}\text { curvilinear hatched lines and } \\
\text { zone }\end{array}$ & - & 1 & 1 \\
\hline diagonal lines & 9 & - & 9 \\
\hline diagonal opposed lines & 3 & 25 & 28 \\
\hline horizontal lines & 10 & 1 & 11 \\
\hline horizontal and diagonal lines & 3 & 5 & 8 \\
\hline $\begin{array}{l}\text { horizontal and diagonal opposed } \\
\text { lines }\end{array}$ & 3 & - & 3 \\
\hline $\begin{array}{l}\text { horizontal, diagonal, and } \\
\text { vertical lines }\end{array}$ & 1 & - & 1 \\
\hline horizontal and vertical lines & 1 & - & 1 \\
\hline opposed lines & - & 2 & 2 \\
\hline parallel lines & - & 77 & 77 \\
\hline straight line & - & 23 & 23 \\
\hline Incised-Punctated & & & 38 \\
\hline $\begin{array}{l}\text { curvilinear incised zone filled } \\
\text { with circular punctates }\end{array}$ & - & 3 & 3 \\
\hline $\begin{array}{l}\text { diagonal lines above fingernail- } \\
\text { punctated rows }\end{array}$ & - & 1 & 1 \\
\hline $\begin{array}{l}\text { diagonal incised panels filled } \\
\text { with tool punctates }\end{array}$ & - & 1 & 1 \\
\hline $\begin{array}{l}\text { diagonal opposed lines above } \\
\text { tool punctated row/rows }\end{array}$ & - & 2 & 2 \\
\hline $\begin{array}{l}\text { diagonal opposed triangle el. } \\
\text { filled with tool punctates }\end{array}$ & 1 & 3 & 4 \\
\hline $\begin{array}{l}\text { horizontal incised line above } \\
\text { circular punctated row at } \\
\text { rim-body juncture }\end{array}$ & - & 1 & 1 \\
\hline $\begin{array}{l}\text { horizontal panel filled with } \\
\text { circular punctates }\end{array}$ & 1 & - & 1 \\
\hline $\begin{array}{l}\text { horizontal incised panels } \\
\text { filled with large crescent- } \\
\text { shaped fingernail punctates }\end{array}$ & 4 & 7 & 11 \\
\hline
\end{tabular}


Table 45. Decorative methods and elements in utility ware sherds from the Chupik site (41ML44), continued.

\begin{tabular}{|c|c|c|c|}
\hline Method/Element & Rim & Body & $\mathrm{N}$ \\
\hline $\begin{array}{l}\text { horizontal incised panels } \\
\text { filled with large crescent- } \\
\text { shaped fingernail punctates } \\
\text { above rows of tool punctates }\end{array}$ & 1 & 2 & 3 \\
\hline $\begin{array}{l}\text { horizontal and diagonal lines } \\
\text { above fingernail punctated } \\
\text { rows }\end{array}$ & - & 1 & 1 \\
\hline $\begin{array}{l}\text { parallel lines and adjacent } \\
\text { fingernail punctated zone }\end{array}$ & - & 1 & 1 \\
\hline $\begin{array}{l}\text { rectangular incised panel filled } \\
\text { with tool punctates }\end{array}$ & - & 1 & 1 \\
\hline $\begin{array}{l}\text { rectilinear incised panel filled } \\
\text { with circular punctates }\end{array}$ & - & 1 & 1 \\
\hline $\begin{array}{l}\text { straight line and adjacent } \\
\text { circular punctated zone }\end{array}$ & - & 1 & 1 \\
\hline $\begin{array}{l}\text { straight line and adjacent } \\
\text { fingernail punctated zone }\end{array}$ & - & 2 & 2 \\
\hline $\begin{array}{l}\text { straight line and adjacent } \\
\text { tool punctated zone }\end{array}$ & - & 4 & 4 \\
\hline Punctated & & & 205 \\
\hline $\begin{array}{l}\text { circular punctated, single } \\
\text { punctation }\end{array}$ & - & 1 & 1 \\
\hline circular punctated rows & - & 4 & 4 \\
\hline fingernail punctated rows & 2 & 179 & 181 \\
\hline $\begin{array}{l}\text { fingernail punctated rows, int. } \\
\text { vessel surface }\end{array}$ & - & 1 & 1 \\
\hline $\begin{array}{l}\text { fingernail punctated curvilinear } \\
\text { rows }\end{array}$ & - & 3 & 3 \\
\hline $\begin{array}{l}\text { fingernail punctated, diagonal } \\
\text { opposed rows }\end{array}$ & - & 1 & 1 \\
\hline $\begin{array}{l}\text { fingernail punctated opposed } \\
\text { curvilinear rows }\end{array}$ & - & 1 & 1 \\
\hline $\begin{array}{l}\text { fingernail punctated, single } \\
\text { punctation }\end{array}$ & - & 5 & 5 \\
\hline tool punctated rows & - & 6 & 6 \\
\hline tool punctated, single punctation & 1 & 1 & 2 \\
\hline Totals & 40 & 370 & 410 \\
\hline
\end{tabular}


The sherds from punctated vessels are overwhelmingly decorated with rows of fingernail punctations (95 percent), including one bowl that has rows of fingernail punctates on the interior vessel surface (see Table 45). A few sherds have curvilinear or diagonal opposed rows (Figure 54a), but most have horizontal rows of fingernail punctations on the rim and/or the vessel body. These are likely from Kiam Incised and Weches Fingernail Impressed jars. The vessel sherds with either circular punctated or tool punctated rows comprise 2.4 and 3.9 percent, respectively, of the punctated sherds in the assemblage.

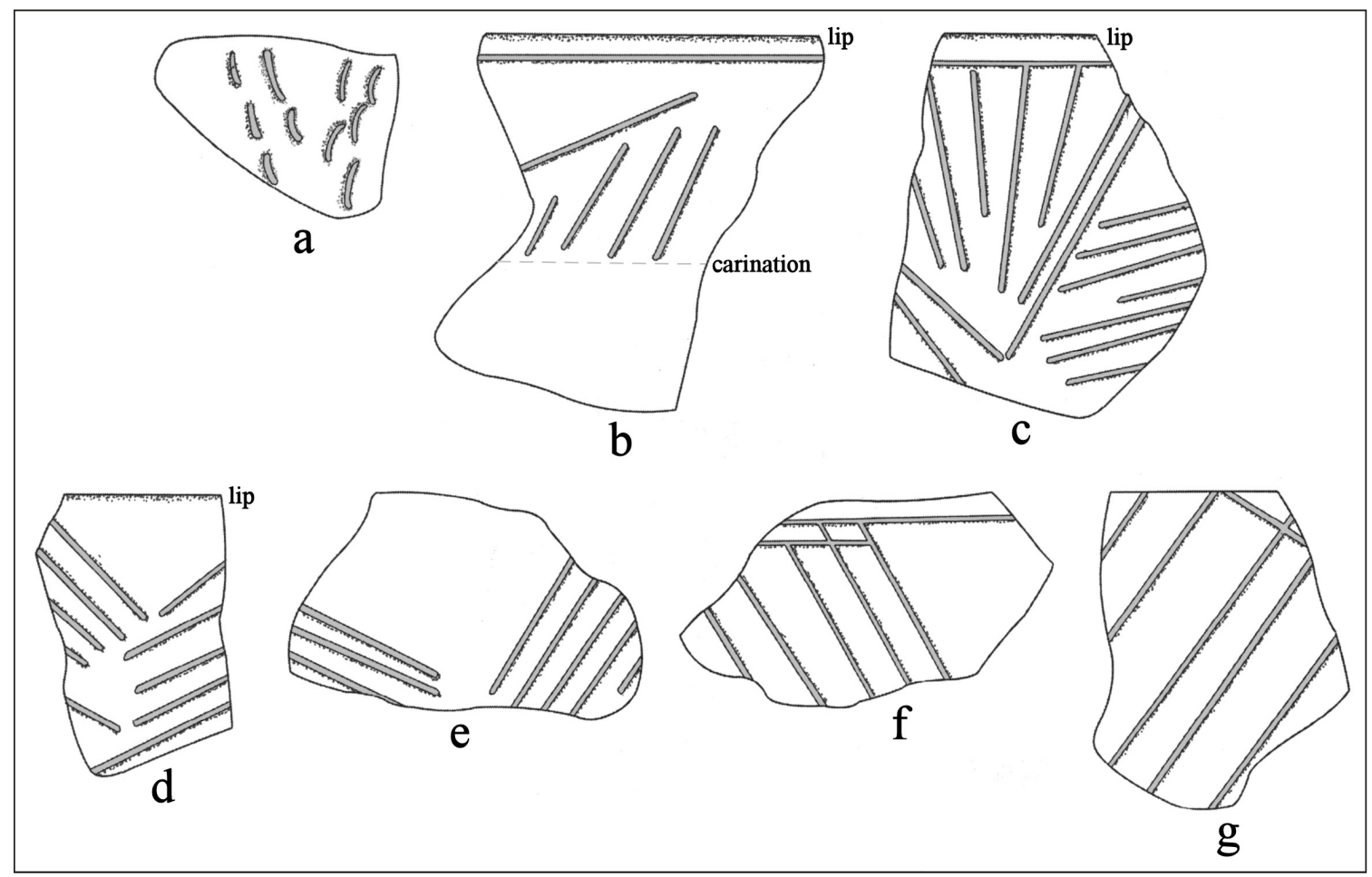

\section{Figure 54. Selected decorative elements on utility ware sherds from the Chupik site (41ML44): a, body sherd with diagonal opposed fingernail punctated rows; $b$-g, incised rim and body sherds.}

The sherds from incised vessels at the Chupik site have horizontal, diagonal, and diagonal opposed incised elements on the rim and vessel body (see Table 45 and Figure 54b-g). These incised sherds are likely from Davis Incised and Dunkin Incised vessels. Less than 2 percent of the incised sherds have curvilinear lines or hatched zones.

The most common decorative elements on the incised-punctated sherds are rim and body sherds with horizontal incised panels filled with large crescent-shaped fingernail punctations (Figure 55a-g; see also Table 45); 71 percent of the incised-punctated rim sherds are from vessels with these decorative elements. These sherds are from Weches Fingernail Impressed, var. Weches vessels (see Stokes and Woodring 1981:Figure 22n-q). These vessels also often have rows of punctations on the vessel bodies (Figure 55d, h).

Other incised-punctated vessel sherds feature incised triangles filled with punctations (Figure 56a, e), or horizontal panels filled with small circular punctations (Figure 56b). Other sherds from Dunkin Incised vessels have horizontal and diagonal as well as horizontal and diagonal opposed incised lines on the vessel rim and rows of tool punctations or fingernail punctations on the vessel body (Figure 56g-h). About 16 percent of the incised-punctated sherds are from Crockett Curvilinear Incised and Pennington Punctated-Incised vessels (Figure 56c-d, f). 


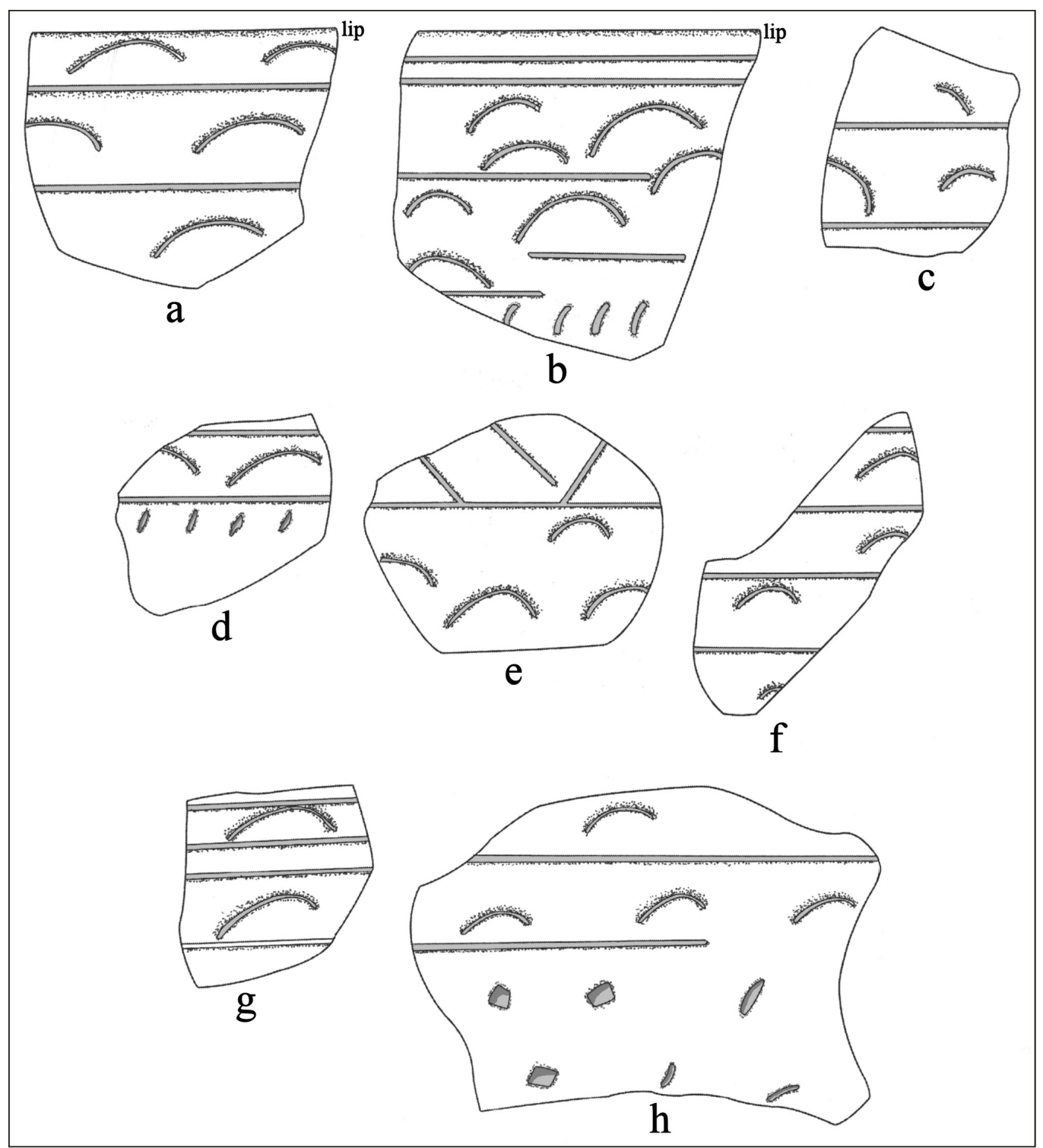

Figure 55. Weches Fingernail Impressed rim and body sherds from the Chupik site (41ML44).

The few brushed body sherds account for only approximately 1 percent of the utility ware assemblage from the site (see Table 45). The presence of sherds from at least two vessels with brushing decorative elements suggests that the occupation at the Chupik site likely lasted past ca. A.D. 1200, when brushed utility ware vessels began to be commonly made in certain East Texas Caddo sites.

Among the fine ware sherds, 96.2 percent are from engraved vessels; the 12 fine ware rim sherds are from engraved vessels (Table 46). Only 4 percent of the engraved sherds have had a red clay pigment rubbed in the engraved lines. The remaining 3.8 percent of the fine ware sherds are from red-slipped vessels, probably from Sanders Slipped bowls or carinated bowls. 


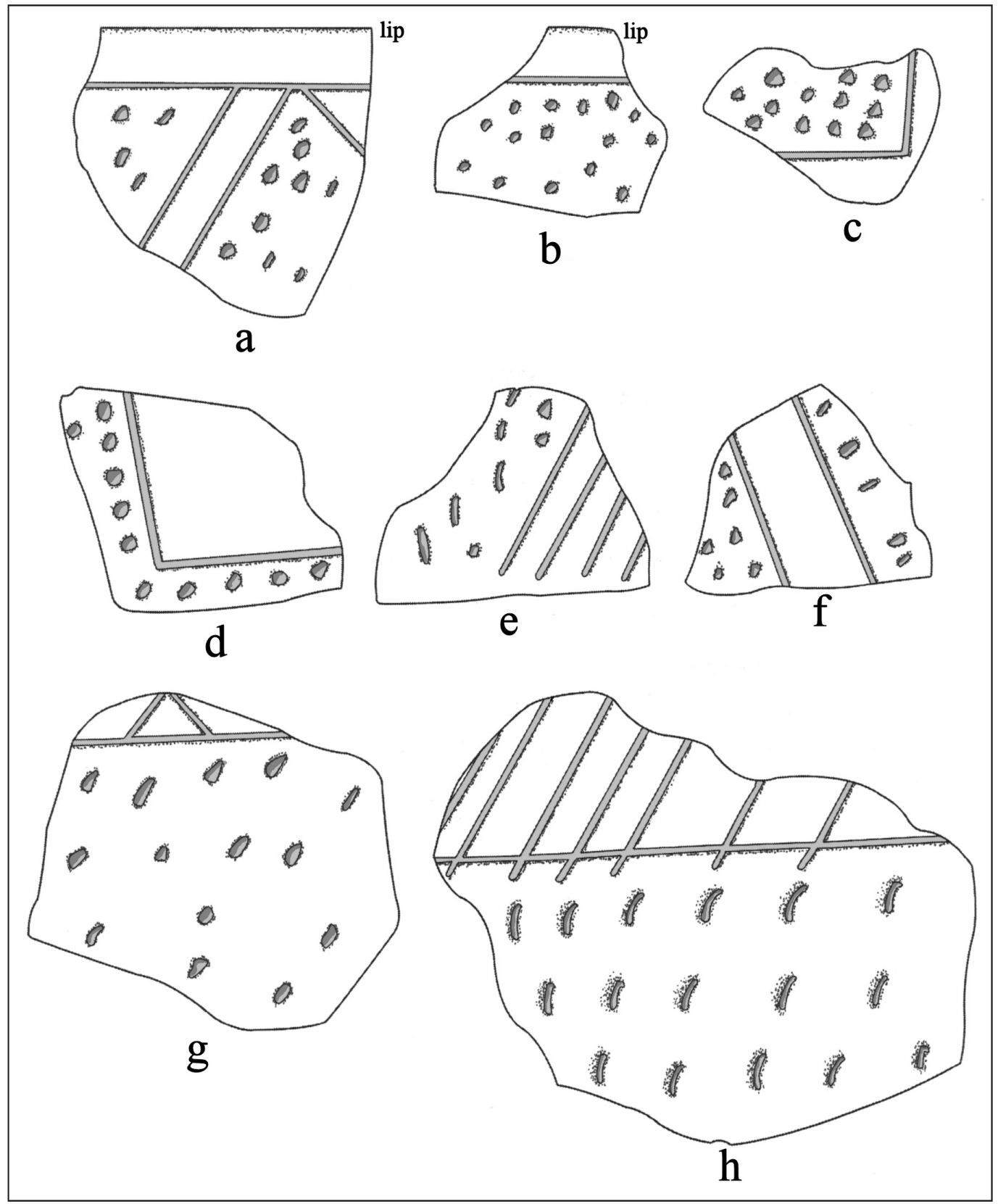

Figure 56. Selective decorative elements on incised-punctated utility ware sherds from the Chupik site (41ML44).

Table 46. Decorative methods and elements in fine ware sherds from the Chupik site (41ML44).

\begin{tabular}{llll}
\hline Method/Element & Rim & Body & N \\
\hline $\begin{array}{l}\text { Engraved } \\
\text { cross-hatched lines }\end{array}$ & - & 4 & $\mathbf{7 6}$ \\
curvilinear lines & & & 4 \\
curvilinear lines and nested & 1 & 2 & 3 \\
hatched zones & - & 1 & 1
\end{tabular}


Table 46. Decorative methods and elements in fine ware sherds from the Chupik site (41ML44), continued.

\begin{tabular}{|c|c|c|c|}
\hline Method/Element & Rim & Body & $\mathrm{N}$ \\
\hline $\begin{array}{l}\text { curvilinear and diagonal opposed } \\
\text { lines }\end{array}$ & - & 2 & 2 \\
\hline curvilinear and straight lines & - & 1 & 1 \\
\hline diagonal lines & 2 & - & 2 \\
\hline hatched zone & 1 & - & 1 \\
\hline horizontal lines & 3 & - & 3 \\
\hline $\begin{array}{l}\text { horizontal and cross-hatched } \\
\text { lines }\end{array}$ & 1 & 2 & 3 \\
\hline $\begin{array}{l}\text { horizontal and curvilinear lines } \\
\text { and cross-hatched circle el. }\end{array}$ & 1 & - & 1 \\
\hline horizontal and diagonal lines & 1 & 5 & 6 \\
\hline $\begin{array}{l}\text { horizontal and diagonal opposed } \\
\text { lines }\end{array}$ & 1 & - & 1 \\
\hline $\begin{array}{l}\text { horizontal lines and rectilinear } \\
\text { panel }\end{array}$ & - & 1 & 1 \\
\hline $\begin{array}{l}\text { horizontal line and vertical panel } \\
\text { with excised zone }\end{array}$ & - & 1 & 1 \\
\hline opposed lines & - & 4 & 4 \\
\hline parallel lines & - & 16 & 16 \\
\hline parallel and curvilinear lines & - & 1 & 1 \\
\hline $\begin{array}{l}\text { parallel lines and excised } \\
\text { pendant triangle }\end{array}$ & - & 1 & 1 \\
\hline straight line & - & 17 & 17 \\
\hline $\begin{array}{l}\text { vertical hatched and cross- } \\
\text { hatched panels }\end{array}$ & 1 & - & 1 \\
\hline $\begin{array}{l}\text { zig-zag lines and excised } \\
\text { triangles }\end{array}$ & - & 3 & 3 \\
\hline Red-Slipped & & & 3 \\
\hline ext. red-slipped & - & 2 & 2 \\
\hline int./ext. red-slipped & - & 1 & 1 \\
\hline Totals & 12 & 67 & 79 \\
\hline
\end{tabular}

The engraved rim sherds have horizontal lines (Hickory Engraved), diagonal lines, a hatched zone (Figure 57a), and combinations of horizontal lines and cross-hatched, curvilinear, diagonal (Figure 57b), or diagonal opposed lines (Figure 57c-d; see also Table 45). One rim has vertical hatched and cross- 
hatched panels (Figure 57j). Three distinctive Holly Fine Engraved body sherds have zig-zag engraved lines with excised triangles (Figure 57f; see also Stokes and Woodring 1981:168-169 and Figure 20j). A body sherd from a carinated bowl has a horizontal line as well as a vertical engraved panel partially filled with an excised zone (Figure 57h), while another carinated bowl sherd has a horizontal engraved line above the carination as well as a panel with cross-hatched engraved lines (Figure 57i).

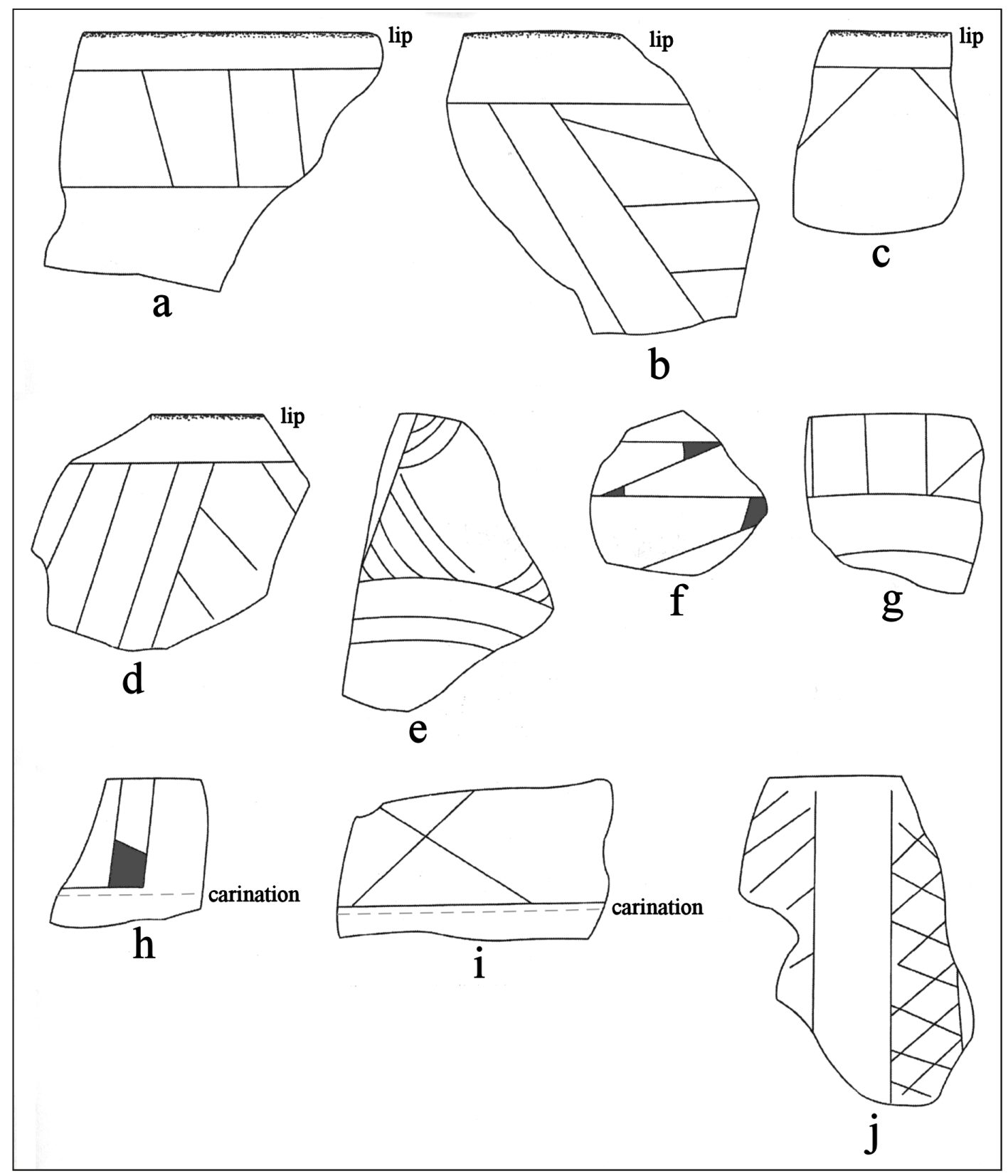

Figure 57. Selected engraved decorative elements in the fine ware sherds from the Chupik site (41ML44): a-d, f, h-j, carinated bowl sherds; e, g, bottle sherds. 
Sherds from engraved bottles, likely Holly Fine Engraved vessels (see Suhm and Jelks 1962:Plate $40 \mathrm{e}, \mathrm{g}$ ) have sets of curvilinear engraved lines with opposed vertical and diagonal lines (see Figure 57g) on the vessel body. Another body sherd from a bottle at the Chupik site has curvilinear engraved lines and a panel on the vessel body with sets of short curvilinear engraved lines in each of the corners of the panel (see Figure 57e).

In summary, the ceramic artifacts from the Chupik site are from a component that dates between ca. A.D. 1000-1200 or a bit after ca. A.D. 1200 (because of the few brushed and brushed-incised sherds in the assemblage); Krieger (Newell and Krieger 1949:196) and Story (2000) had previously classified the site as being an Early Caddo Alto focus or phase component.

The three uncorrected radiocarbon dates from the site are A.D. $1060 \pm 340$, A.D. $1190 \pm 320$, and A.D. $1210 \pm 260$ (Story 1990b:674-675); their extreme standard deviations render these dates of little analytical value, though their mean date is A.D. 1153. This component has numerous decorated ceramics of Early Caddo period style, including Pennington Punctated-Incised, Dunkin Incised, Weches Fingernail Impressed, Holly Fine Engraved, and Hickory Engraved (see Locke 1975:6). Locke's (1975:65-66) preliminary X-ray diffraction analysis of a few Chupik ceramic sherds and local clay sources "suggests material from the Chupek [sic] site represents trade ware, not locally manufactured pottery."

There is one bone-tempered long-stemmed Red River style pipe stem sherd in the Chupik site collections. The sherd is bone-tempered, and has an exterior stem diameter of $10.7 \mathrm{~mm}$; the stem hole itself is $4.5 \mathrm{~mm}$ in diameter. This sherd is probably from the Graves Chapel variety of Red River pipe, which was made by Caddo groups between ca. A.D. 1000-1200 (Hoffman 1967:9).

\section{Asa Warner (41ML46 or 39D3-2)}

The Asa Warner site is on an alluvial terrace of the Brazos River about $12 \mathrm{~km}$ southeast of the city of Waco (Watt 1956:Figure 1; Wright 1997). The TARL collections from the site include collections donated by J. Shannon and Frank Watt as well as material culture remains from the 1973 Texas Archeological Society (TAS) Field School (Richmond et al. 1985:149-150; Wright 1997). A total of 425 ceramic sherds were recovered in the TAS Field School work from at least 10-15 separate vessels of plain ware, utility ware, and fine ware (Turner 1997:234). Prior to the TAS Field School, the Central Texas Archeological Society periodically carried out rather extensive excavations at the Asa Warner site (Watt 1941b, 1942, 1953, 1956), exposing habitation deposits and burials.

A wide variety of decorated Caddo ceramic wares were recovered in the Central Texas Archeological Society excavations, particularly sherds that Watt (1956:23) believed were from East Texas Late Caddo period Frankston phase vessels; vessel types present were bowls and carinated bowls. There are sherds with engraved, incised, brushed, and punctated vessels, likely from both pre-A.D. 1400 and post-A.D. 1400 types (Watt 1956:Figure 9a-b) such as Sanders Engraved, Poynor Engraved, Hume Engraved, and Bullard Brushed. Turner (1997:235) dates most of the ceramics from the Asa Warner site from ca. A.D. 1200-1300, though he concedes that some are from vessels made in the early part of the Late Caddo period (ca. A.D. 1400-1480), and he considered the ceramics to be Caddo in origin.

A few sherds $(n=14)$ from that work are in the Mayborn Museum Complex holdings. They include 12 plain body sherds, 92 percent from grog-tempered vessels and the remainder from a bone-tempered vessel. The two decorated sherds include a grog-tempered body sherd with fingernail punctated rows and a grog-tempered body sherd with parallel brushed-incised marks and lines as well as overlying parallel incised lines (Figure 58a-b). This particular sherd is from a Spradley Brushed-Incised vessel, made after 
A.D. 1680 by Caddo potters in the Neches-Angelina river basins in East Texas. This sherd suggests a limited use of the site in historic contact times, likely by a Wichita group that had obtained a Spradley Brushed-Incised vessel from an Hasinai Caddo group.

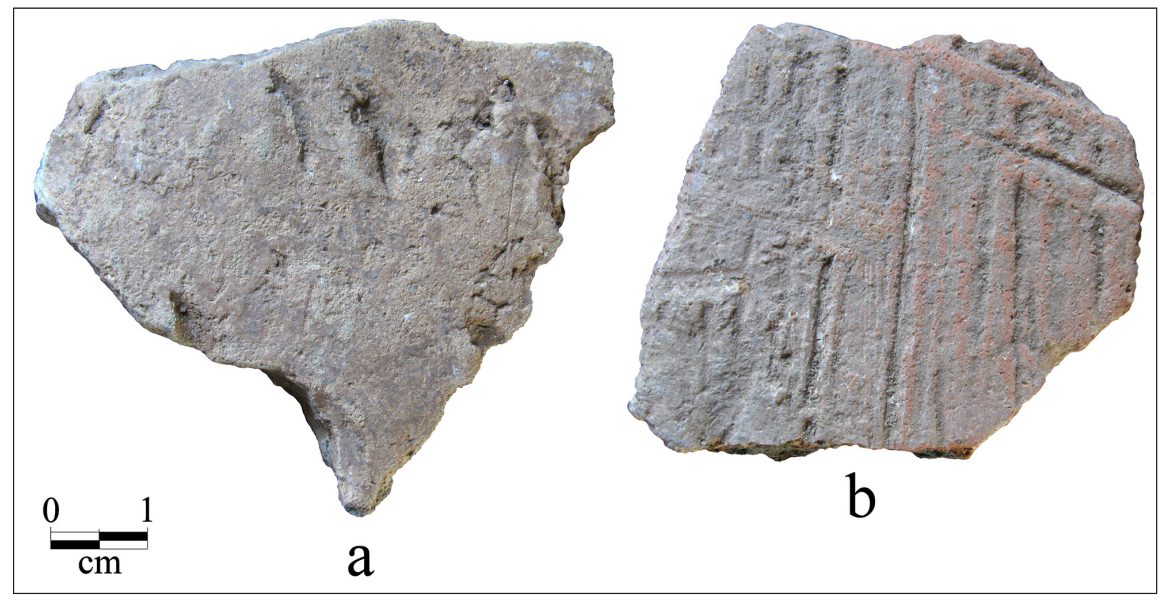

Figure 58. Selected decorated sherds from the Asa Warner site in the Mayborn Museum Complex collections.

There are 311 sherds from ceramic vessels in the TARL collections from the Asa Warner site (Table 47). About 75 percent of the sherds are from grog-tempered vessels, and the remainder are from bonetempered wares. The 159 decorated sherds in the collection include sherds from both utility (67 percent) and fine ware (33 percent) vessels. The decorated sherd sample discussed herein does not include the four decorated sherds from the site that were analyzed for instrumental neutron activation analysis and petrographic analysis (Perttula et al. 2003:14-16 and Figure 3): two engraved sherds, one fingernail punctated body sherd, and one sherd with diagonal opposed incised lines.

Table 47. Ceramic sherds from the Asa Warner site (41ML46) in the TARL collections.

\begin{tabular}{llll}
\hline Ware & grog-tempered & bone-tempered & N \\
\hline Plain Ware & & & 21 \\
plain rim & 14 & 7 & 117 \\
plain body & 94 & 23 & 14 \\
base & 8 & 6 & 152 \\
Subtotal, Plain Ware & 116 & 36 & \\
Utility Ware & & & 2 \\
Brushed & 2 & - & 64 \\
Incised & 47 & 17 & 8 \\
Incised-Punctated & 8 & - & 32 \\
Punctated & 21 & 11 & 106 \\
Subtotal, Utility Ware & 78 & 28 & 42 \\
Fine Ware & & & 10 \\
Engraved & 27 & 15 & 1 \\
Engraved-Punctated & 10 & - & 53 \\
Red-Slipped & 1 & - & 311 \\
Subtotal, Fine Ware & 38 & 15 & \\
\hline Totals & 232 & 79 & \\
\hline
\end{tabular}


Among the utility ware sherds in the TARL collections from the Asa Warner site, 60.4 percent are from vessels with incised decorative elements (and 75 percent of the utility ware rims) (Table 48), another 30.2 percent are from vessels with punctated decorative elements (and 17 percent of the utility ware rims), 7.5 percent have incised-punctated decorative elements (and 8.3 percent of the utility ware rims), and 1.9 percent have brushed decorative elements.

Table 48. Decorative methods and elements in utility ware and fine ware sherds in the TARL collections from the Asa Warner site (41ML46).

\begin{tabular}{llll}
\hline Method/Element & Rim & Body & $N$ \\
\hline
\end{tabular}

Utility Ware

Brushed

overlapping brushed marks

parallel brushing marks

Incised

cross-hatched lines

diagonal lines

6

diagonal opposed zones

horizontal lines

opposed lines

parallel lines

straight line

$\begin{array}{lll}- & 1 & 1 \\ - & 1\end{array}$

1

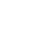

Incised-Punctated

diagonal incised triangle filled

with tool punctates

horizontal lines (rim)-fingernail

punctated rows (body)

horizontal-vertical lines above rows of tool punctates

straight incised line and adjacent

fingernail punctated zone

straight incised line and adjacent

tool punctated zone

Punctated

fingernail punctated rows

tool punctated rows

\section{Fine Ware}

\section{Engraved}

cross-hatched lines 
Table 48. Decorative methods and elements in utility ware and fine ware sherds in the TARL collections from the Asa Warner site (41ML46), continued.

\begin{tabular}{|c|c|c|c|}
\hline Method/Element & Rim & Body & $\mathrm{N}$ \\
\hline diagonal opposed lines & - & 2 & 2 \\
\hline $\begin{array}{l}\text { diagonal, rectilinear, and } \\
\text { cross-hatched zone }\end{array}$ & 1 & - & 1 \\
\hline hatched curvilinear zone & - & 1 & 1 \\
\hline hatched panels & - & 2 & 2 \\
\hline $\begin{array}{l}\text { horizontal and curvilinear lines } \\
\text { and excised pendant triangles }\end{array}$ & - & 2 & 2 \\
\hline opposed lines & 1 & 6 & 7 \\
\hline parallel lines & - & 2 & 2 \\
\hline straight line & - & 2 & 2 \\
\hline vertical lines & - & 1 & 1 \\
\hline \multicolumn{4}{|l|}{ Engraved-Punctated } \\
\hline $\begin{array}{l}\text { parallel engraved lines and excised } \\
\text { punctated zone }\end{array}$ & - & 6 & 6 \\
\hline $\begin{array}{l}\text { straight engraved line and adjacent } \\
\text { excised punctated zone }\end{array}$ & - & 4 & 4 \\
\hline \multicolumn{4}{|l|}{$\underline{\text { Red-Slipped }}$} \\
\hline int. red-slipped & - & 1 & 1 \\
\hline Totals & 21 & 138 & 159 \\
\hline
\end{tabular}

The few brushed sherds in the utility ware assemblage (see Table 48) indicate that at least two jars with brushing marks (at least on the vessel bodies) were used, broken, and discarded at the Asa Warner site. In East Texas, sherds from brushed utility ware vessels, particularly jars, are a distinctive characteristic of both Middle, Late, and Historic Caddo sites in much of East Texas. It also appears to be the case that the relative proportions of brushed utility wares increase through time in those areas where brushed vessels were made and used, such that sherds with brushing marks may comprise as much as 90 percent of all the decorated sherds in some post-A.D. 1400 East Texas ceramic assemblages. These sherd data suggest that the Asa Warner site was occupied at least sometime after ca. A.D. 1200. In the East Texas Caddo ceramic sherd database (Perttula 2015a), only a few ca. A.D. 1200-1430 sites have assemblages with high proportions ( $>60$ percent of the decorated sherd assemblage) of brushed sherds; these occur in the mid-Sabine and Big Cypress Creek drainage basins. Late Caddo ceramic assemblages in East Texas with high proportions of brushed sherds occur in the upper and mid-Neches (Frankston phase sites), Angelina, middle Sabine and Big Cypress (Titus phase sites), and sites on tributaries of the Sabine River west of the Toledo Bend Reservoir area (see Perttula 2015a:Figure 5). Caddo ceramic assemblages without considerable amounts of brushed sherds occur in the upper Sabine, Sulphur, and Red River basins.

Rims from incised vessels have cross-hatched, diagonal, and horizontal decorative elements (see Table 48). These are likely from Davis Incised and Dunkin Incised jars. Cross-hatched and opposed incised line elements are predominant in the body sherds, and there is one distinctive Dunkin Incised body sherd with diagonal opposed triangle elements (Figure 59a-b). 


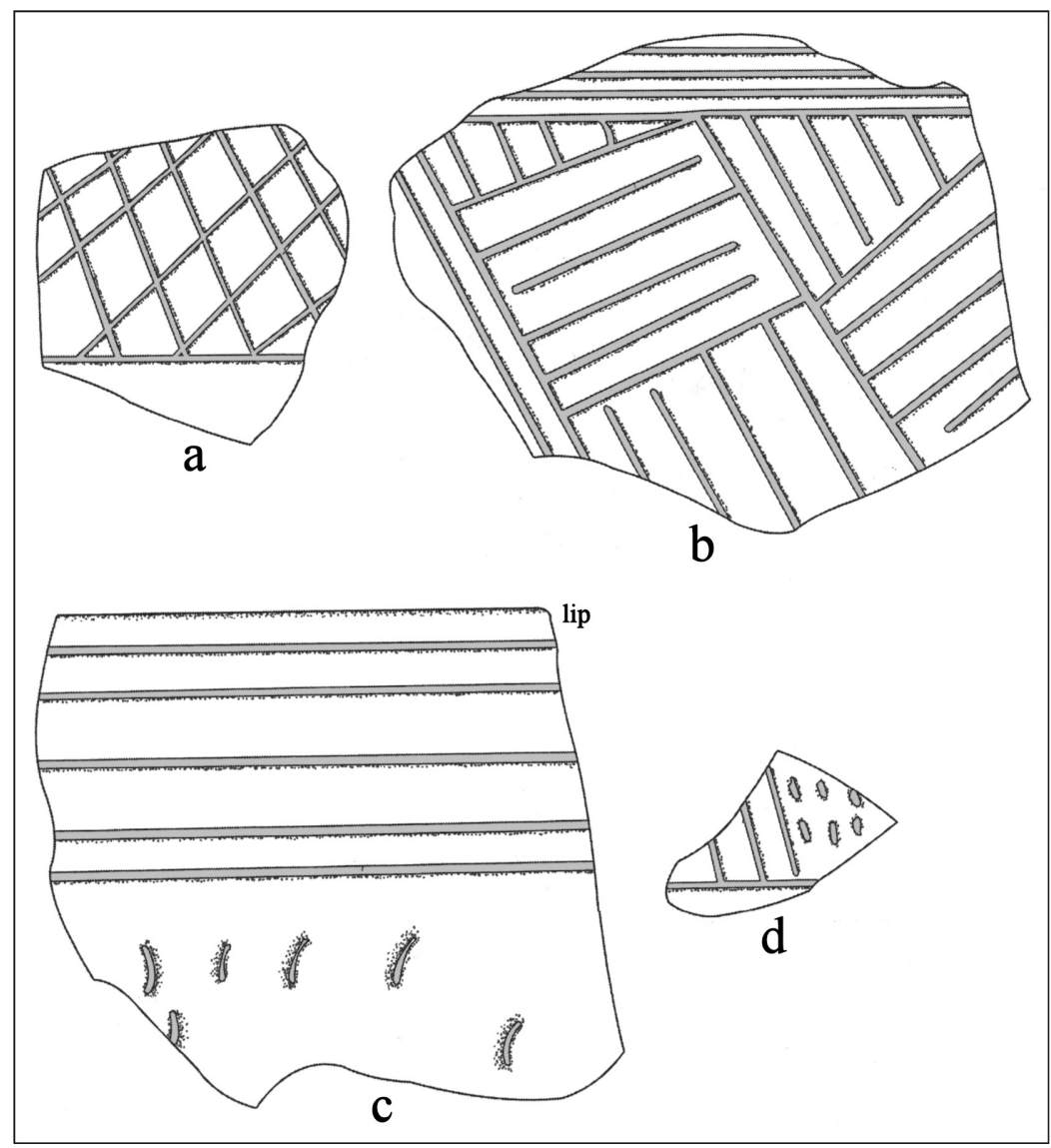

Figure 59. Decorative elements on selected utility ware sherds from the Asa Warner site (41ML46): a, cross-hatched incised body sherd; b, Dunkin Incised body sherd; c, Kiam Incised rim sherd; $d$, incised-punctated body sherd.

The one incised-punctated rim sherd is from a Kiam Incised jar. The rim has five horizontal incised lines, with at least two rows of large fingernail punctates on the upper vessel body (see 59c). Other incised-punctated sherds feature either zones of fingernail or tool punctations adjacent to one or more straight incised lines, or have diagonal opposed lines forming incised triangles filled with tool punctations (see Figure 59d). This body sherd may be from a Canton Incised jar.

The engraved rim sherds feature geometric elements, namely cross-hatched lines, diagonal lines, opposed lines (Figure 60a), or one sherd with a combination of diagonal, rectilinear, and cross-hatched zone elements (see Table 48). Except for the latter, these engraved sherds are from Sanders Engraved vessels. Body sherds feature similar decorative elements (Figure 60b). Other engraved sherds have hatched zones and panels (Figure 60c-d)

One body sherd from a bottle has horizontal and curvilinear engraved lines with excised pendant triangles (see Figure 60g); Turner (1997:231) suggests this vessel may date to the latter part of the Middle Caddo period. Ten body sherds - four from bottles and six from carinated bowls - have engraved lines and adjacent zones of excised punctations (see Figure 60e-f). These may be from Spiro Engraved vessels (cf. Suhm and Jelks 1962:147 and Plate 74b, f, i). One of the engraved-punctated carinated bowl sherds has a red pigment rubbed in the engraved lines. Four other engraved sherds also have a red pigment rubbed in the engraved lines; a total of 9.6 percent of the engraved fine ware sherds from the Asa Warner site have a red pigment added to the decorative elements. 


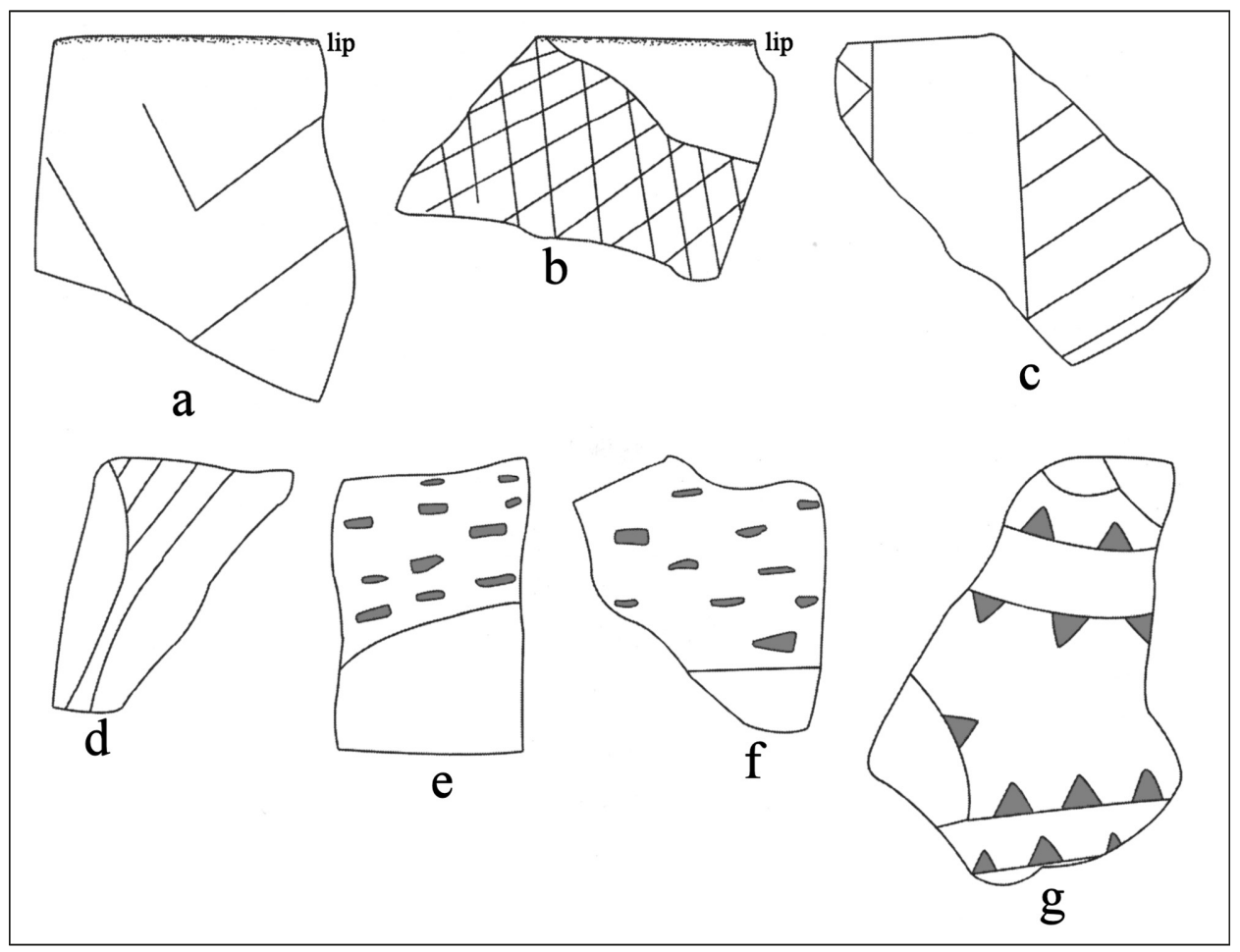

Figure 60. Decorative elements on selected fine ware sherds from the Asa Warner site (41ML46): a, opposed engraved rim sherd; b, cross-hatched engraved zone body sherd; c-d, body sherds with hatched zones and panels; e-f, engraved-punctated bottle body sherds; g, engraved bottle sherd.

The single red-slipped sherd from the Asa Warner site may be from a Sanders Slipped bowl. Redslipped fine wares (bowls, carinated bowls, and an occasional bottle) are a common part of ancestral Caddo ceramic assemblages in several parts of East Texas, most notably in sites that predate ca. A.D. 1400 in the middle Red River, the Big Cypress Creek basin, the upper Sulphur and Sabine River basins, and the middle Sabine River basin (Perttula 2015a:Figure 3).

The decorated ceramic assemblage from the Asa Warner site suggests that the main occupation at the site took place after ca. A.D. 1200, and ended by ca. A.D. 1400, if not earlier. Turner (1997:235) dates most of the ceramics from the site to the period from ca. A.D. 1200-1300. Turner (1997:235) also considers the ceramics to be Caddo in origin, and in particular he noted that:

...the quantity of pottery sherds was extremely small at Asa Warner. It is possible that some of the ceramic vessels may have been manufactured at the site, but if so, it was only in very small numbers. Due to the diversity of paste, coloration, and vessel form observed in the Asa Warner collection, it is more probable that the vessels were transported to the site from East Texas over a period of several hundred years. This would indicate that the ceramics are either the product of short occupations by Caddoan [sic] peoples or conversely the trade of Caddo vessels to a Central Texas people who did not manufacture their own pottery.

One long-stemmed Red River pipe stem sherd is in the TARL collections from the Asa Warner site. It is from a bone-tempered pipe, and has $4.0 \mathrm{~mm}$ thick stem walls. 


\section{Cement Hill 2 Site (41ML66)}

The Cement Hill 2 site is on an upland slope just below the Balcones Escarpment, about one mile south of the South Bosque River and several miles west of the Brazos River (Atlee 2004:Figures 1 and 2). In the 1950s, William A. Atlee collected a number of ancestral Caddo sherds and a large vessel section from the site, and these sherds are in the holdings of the Mayborn Museum Complex at Baylor University. The Cement Hill 2 site is separate from, but nearby, the Cement Hill site (41ML43) (Atlee, 1996 personal communication).

Atlee's ceramic sherd collection has 11 bone-tempered Leon Plain body sherds and 14 sherds from Caddo vessels likely made by Frankston phase potters from the upper Neches River basin in East Texas, as well as a large section of a pinched jar. The grog-tempered pinched jar (Figure 61-63; see also Atlee 2004:Figures 3-4) is comprised of more than 30+ conjoined rim and body sherds with a direct rim and a rounded lip. There is a horizontal pinched ridge that parallels the lip, as well as at least three vertical pinched ridges that extend down the vessel body to the base; the area of the exterior vessel body between the ridges has been burnished. Appliqued nodes were added between the pinched ridges. The decoration on this vessel may be a much-simplified version of Killough Pinched (see Suhm and Jelks 1962:Plate 46).

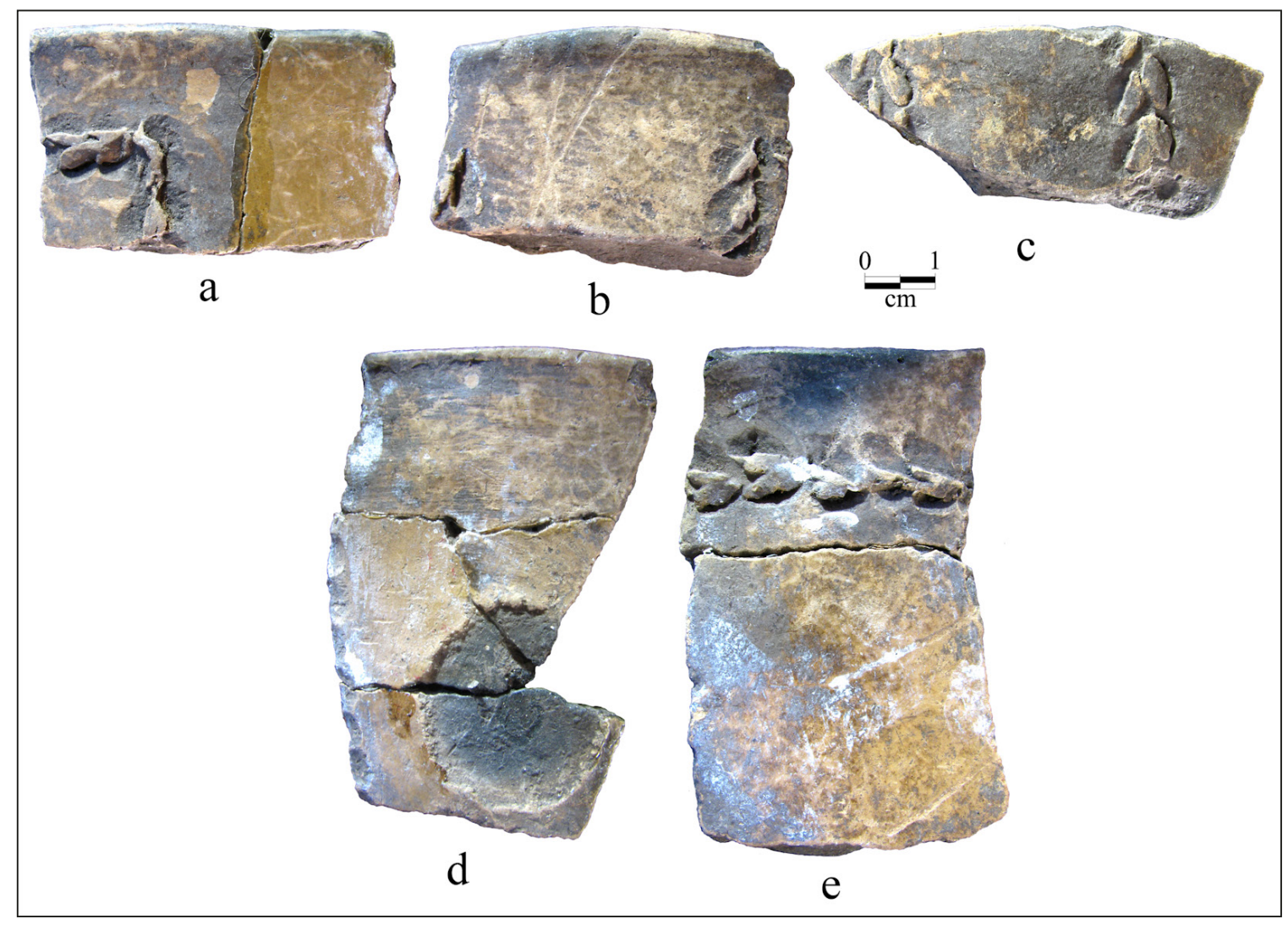

Figure 61. Pinched decorative elements of the large jar from the Cement Hill 2 site (41ML66). 

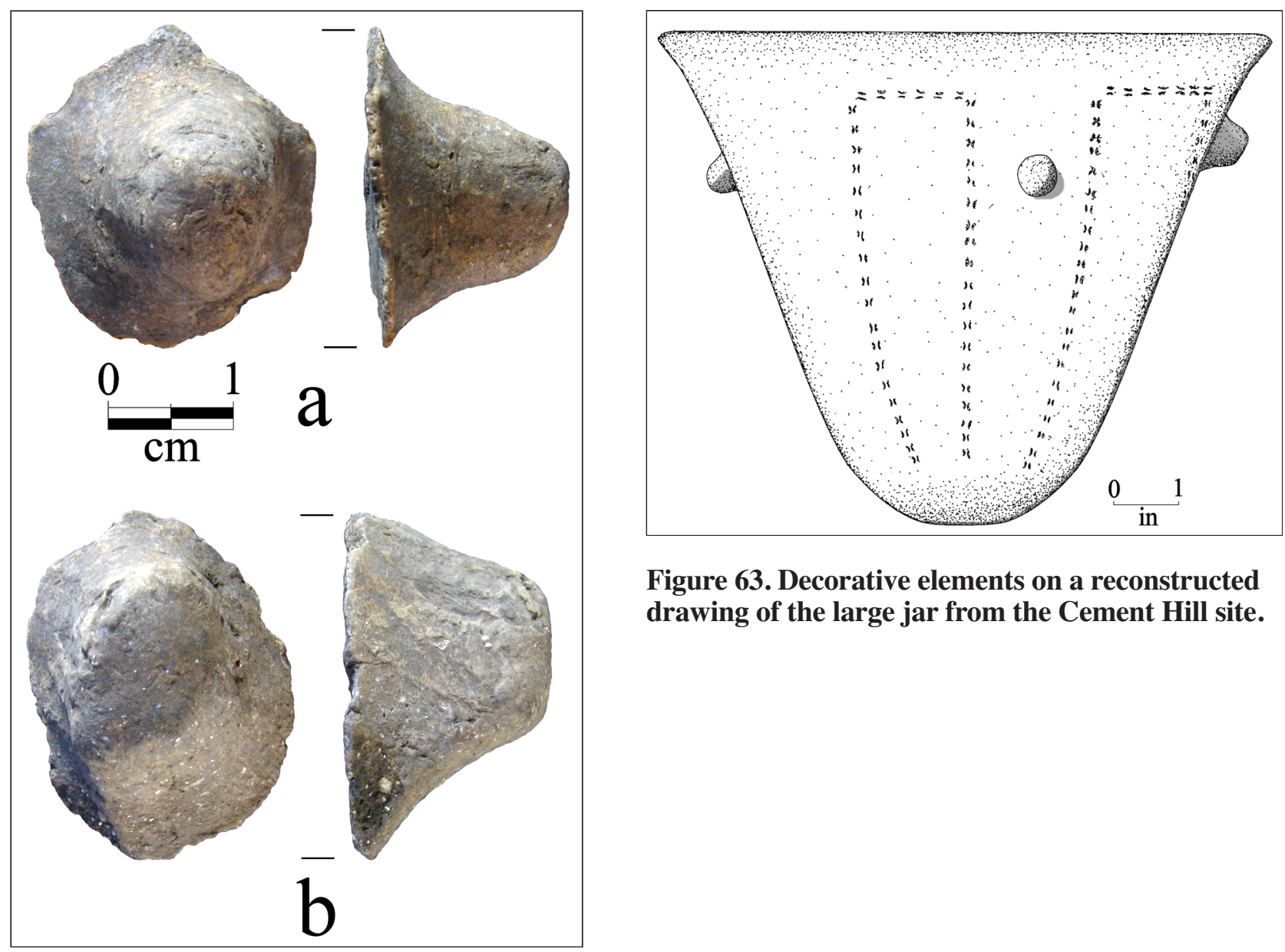

Figure 63. Decorative elements on a reconstructed drawing of the large jar from the Cement Hill site.

Figure 62. Appliqued decorative element on the large jar from the Cement Hill site.

The other Caddo vessel sherds from the site include a grog-bone-tempered plain rim, four plain grogtempered body sherds, one from a carinated bowl, four plain grog-bone-tempered body sherds, and five engraved sherds. One of the engraved sherds is a grog-tempered rim with horizontal and curvilinear lines (see Atlee 2004:Figure 5), and the other four sherds are from a grog-tempered Poynor Engraved bottle. The sherds have closely-spaced parallel and curvilinear engraved lines (see Atlee 2004:Figure 6).

\section{Tonk Creek Shelter (41ML119)}

There is a single "grit-tempered" ceramic vessel sherd from the Tonk Creek Shelter site (Perkins 1956:43) in the Bosque River basin that may be of Caddo manufacture. Both Perdiz and Alba arrow points have been collected from the site in equal numbers, as well as an obsidian core, but it is not known which of these arrow point types is associated with the recovered ceramic sherd.

\section{McMillan Site (41ML162)}

A plain grog-tempered Caddo vessel sherd was recovered in contexts dating between A.D. 14051455 at the McMillan site at Waco Lake on the Brazos River (Mehalchick and Kibler 2008:179). A second Caddo vessel sherd in AU 2 is a grog-tempered body sherd with one incised line (Mehalchick and 
Kibler 2008:209). Test excavations recovered a single plain shell-tempered body sherd in contexts dating between 2000-1400 years B.P. (Scott et al. 2002:57, 68), and this is not associated with any Caddo or East Texas Woodland ceramic wares.

Mehalchick and Kibler (2008:370) argue that there were ties between Waco area peoples and East Texas Caddo groups, primarily evidenced by Caddo ceramic wares, and that these Waco area peoples were engaged in trade with the Caddo. The Caddo appear to have brought vessels to the Middle Brazos River area, perhaps along with perishables like salt and maize, and exchanged these ceramic vessels for tools of Edwards chert produced by these local peoples (see also Gadus et al. 2006:179-180; Fields 2017).

\section{$41 M L 185$}

Work reported by Scott et al. (2002:90 and Figure 37) recovered two sherds at 41ML185, the first a bone-tempered vessel sherd with cross-hatched incised lines, probably from a Maydelle Incised vessel. The second sherd is a burnished plain bone-tempered body sherd from a Leon Plain vessel. These are likely associated with a post-A.D. 1200 Toyah phase component at the site.

\section{Warner \#1 (39D3-1)}

Watt considered the Warner \#1, \#11, and \#12 sites to be part of the Asa Warner site (Watt 1956:7 and Figure 1). However, because their locations are not known relative to the Asa Warner site (Wright 1997:216-217) in the Brazos River floodplain, except that they are in the Brazos River valley nearby, the ceramic assemblages from these three sites are discussed separately herein.

The sherd sample at the Warner \#1 site includes 22 plain or decorated rim and body sherds (Table 49). Only 59 percent of the sherds from the Warner \#1 site are from grog-tempered vessels; another 18 percent have both grog and bone temper, and 23 percent are from bone-tempered vessels. The use of bone temper in the manufacture of these vessels is considerable, at 41 percent of the sherd assemblage.

Table 49. Sherd sample from the Warner \#1 site, McLennan County, Texas.

\begin{tabular}{lllll}
\hline Ware & grog-tempered & grog-bone-tempered & bone-tempered & $\mathrm{N}$ \\
\hline Plain & 5 & 3 & 3 & 11 \\
Utility & 6 & 1 & 1 & 8 \\
B-P & 1 & - & - & 1 \\
I & 2 & 1 & - & 3 \\
P & 3 & - & 1 & 4 \\
Fine & 2 & - & 1 & 3 \\
E & 2 & - & 1 & 3 \\
\hline Totals & 13 & 4 & 5 & 22 \\
\hline
\end{tabular}

B-P=brushed-punctated; I=incised; $\mathrm{P}=$ punctated; E=engraved

Seventy-three percent of the decorated sherds $(n=11)$ from Caddo vessels at the site are from utility ware jars decorated with brushed-punctated elements, incised lines, and punctations (see Table 49). The brushed-punctated sherd is probably from a Bullard Brushed vessel with a row of fingernail punctations 
adjacent to an area of diagonal brushing (see Suhm and Jelks 1962:21). One of the incised sherds has a cross-hatched triangle element, another has opposed incised lines (possibly from a Maydelle Incised vessel), and the third has simply a single straight incised line. Three of the four punctated body sherds have rows of fingernail punctations (Figure 64), and the other has rows of small circular punctates.

The engraved fine ware sherds include one bonetempered body sherd with a single curvilinear engraved line. Another engraved sherd, from a grog-tempered vessel, has opposed engraved lines, and the third is from a Poynor Engraved vessel made after ca. A.D. 1400, although the variety is uncertain (cf. Perttula 2011:Figure 6-64). This vessel sherd has closely-spaced parallel engraved lines and a red clay pigment had been rubbed in the engraved lines.

The combination of Bullard Brushed, Maydelle Incised, and Poynor Engraved sherds at the Warner \#1 site, along with a number of Leon Plain sherds, suggest the occupation here post-dates ca. A.D. 1400. The Caddo vessel sherds are likely from vessels made by Frankston phase potters in the upper Neches River basin in East Texas.

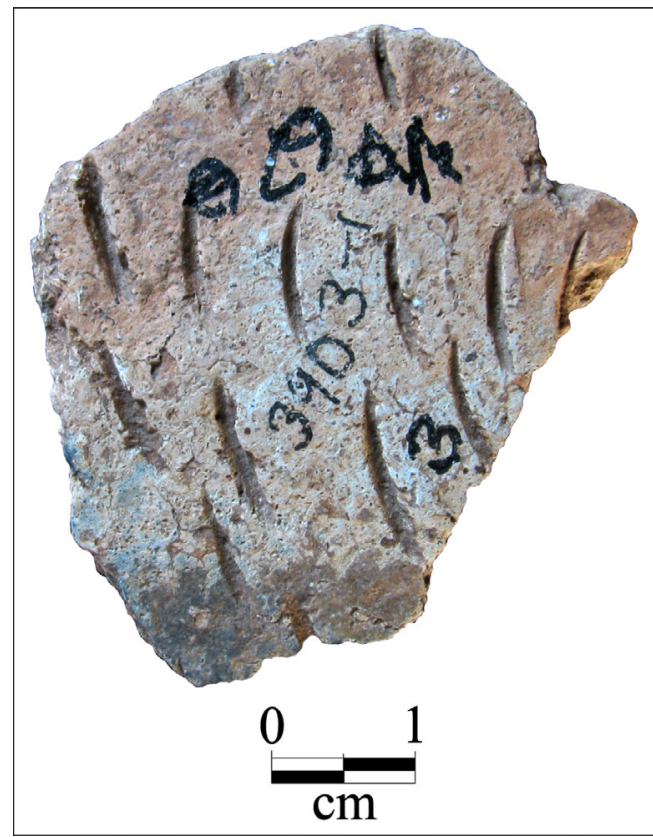

Figure 64. Fingernail punctated body sherd from the Warner \#1 site (39D3-1) in McLennan County, Texas.

\section{Warner \#11 (39D3-11)}

The 92 ceramic vessel sherds in the Warner \#11 assemblage (Table 50) include both Leon Plain sherds $(n=33)$ from a Toyah phase occupation, as well as plain and decorated ancestral Caddo vessel sherds $(n=59)$ of likely Late Caddo Frankston phase age. There are also three pieces of burned clay in the Watt collection from the site, along with a single Perdiz arrow point.

Table 50. Sherd sample from the Warner \#11 site, McLennan County, Texas.

\begin{tabular}{lllll}
\hline Ware & grog-tempered & grog-bone-tempered & bone-tempered & N \\
\hline Plain & 9 & 18 & $48^{*}$ & 75 \\
Utility & 10 & 3 & 3 & 16 \\
B & 6 & - & 1 & 7 \\
B-I & 1 & - & - & 1 \\
I & 1 & - & - & 1 \\
P & 2 & 3 & 2 & 7 \\
Fine & - & 1 & - & 1 \\
E & - & 22 & 51 & 92 \\
\hline Totals & 19 & & & \\
\hline
\end{tabular}

*33 are from Leon Plain vessels

$\mathrm{B}=$ brushed; $\mathrm{B}-\mathrm{I}=$ brushed-incised; $\mathrm{I}=$ incised; $\mathrm{P}=$ punctated; $\mathrm{E}=$ =ngraved 
The Caddo sherds in the collection are from vessels tempered with grog (32 percent), grog-bone (37 percent), and bone (31 percent) (see Table 50). The majority of the grog-tempered sherds are from utility wares with several different kinds of decorative elements, while most of the grog-bone-tempered and bone-tempered sherds are from plain ware.

The utility ware sherds have predominantly either brushed marks or rows of punctations. The brushed and brushed-incised sherds are from Bullard Brushed vessels and have opposed brushed marks $(n=1)$, parallel brushed marks $(n=6)$ (Figure 65a), or parallel brushed-incised marks and lines $(n=1)$. The punctated rim and body sherds have a row of fingernail punctations that begin below the vessel lip and also are on the vessel body (Figure 65b-c). The one sherd with an incised decoration in the Warner \#1 assemblage has a single horizontal incised line below the vessel lip. The one fine ware sherd from the Warner \#1 site has only a single straight engraved line. The dominance of brushed and brushed-incised sherds in the decorated sherd collection from the Warner \#11 site suggests that the Caddo sherds are from vessels made after ca. A.D. 1400 - in the Late Caddo period-by potters living in the Neches River basin in East Texas.

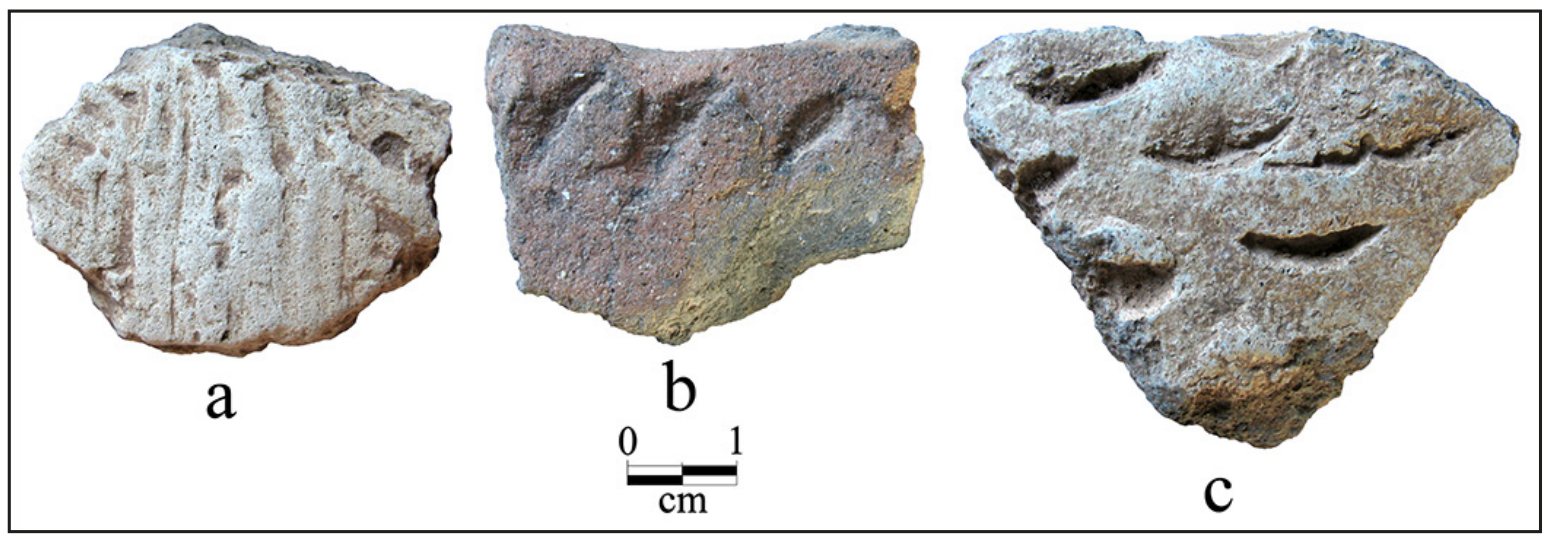

Figure 65. Selected decorated sherds from the Warner \#11 site, McLennan County, Texas.

\section{Warner \#12 (39D3-12)}

Both ancestral Caddo vessel sherds $(\mathrm{n}=57)$ and local Toyah phase bone-tempered Leon Plain vessel sherds $(\mathrm{n}=8)$ are in the Warner \#12 sherd collection assembled by Frank Watt (Table 51). About 98 percent of the sherds from Caddo vessels have been manufactured with grog temper, either as the sole temper ( 82 percent) or in combination with burned bone temper (16 percent); the remaining sherd in the assemblage is from a bone-tempered vessel. 
Table 51. Sherd sample from the Warner \#12 site, McLennan County, Texas.

\begin{tabular}{lllll}
\hline Ware & grog-tempered & grog-bone-tempered & bone-tempered & N \\
\hline Plain & 32 & 7 & $9 *$ & 48 \\
Utility & 11 & 1 & - & 12 \\
A & 2 & - & - & 2 \\
B & 3 & - & - & 3 \\
B-I & 2 & - & - & 2 \\
I & 3 & - & - & 3 \\
P & 1 & 1 & - & 2 \\
Fine & 4 & 1 & - & 5 \\
E & 4 & 1 & - & 5 \\
\hline Totals & 47 & 9 & 9 & 65 \\
\hline
\end{tabular}

*eight sherds are from Leon Plain vessels

A=appliqued; $\mathrm{B}=$ brushed; $\mathrm{B}-\mathrm{I}=$ brushed-incised; I=incised; P=punctated; $\mathrm{E}=$ engraved

The 17 decorated sherds are divided between utility wares ( 71 percent) and fine wares ( 29 percent) (see Table 51); almost all of these sherds are from grog-tempered vessels. Among the utility wares are two body sherds from a Bullard Brushed vessel with a single appliqued node (Figure 66a; see Suhm and Jelks 1962:Plate 11b). Five of the sherds have brushed and brushed-incised marks and lines, including parallel brushed $(n=3)$ and parallel brushed-incised $(n=1)$ sherds from Bullard Brushed jars. Another sherd has opposed brushed marks and overlying parallel incised lines (Figure 66c). Two of the sherds with an incised decoration have either a straight incised line or cross-hatched incised lines; this sherd is likely from a Maydelle Incised jar. The third incised sherd is a grog-tempered rim from a Crockett Curvilinear Incised bowl with a slanted scroll motif and adjacent triangular areas filled with diagonal hatched lines. Both punctated sherds have rows of fingernail punctations on the vessel body (Figure 66b).

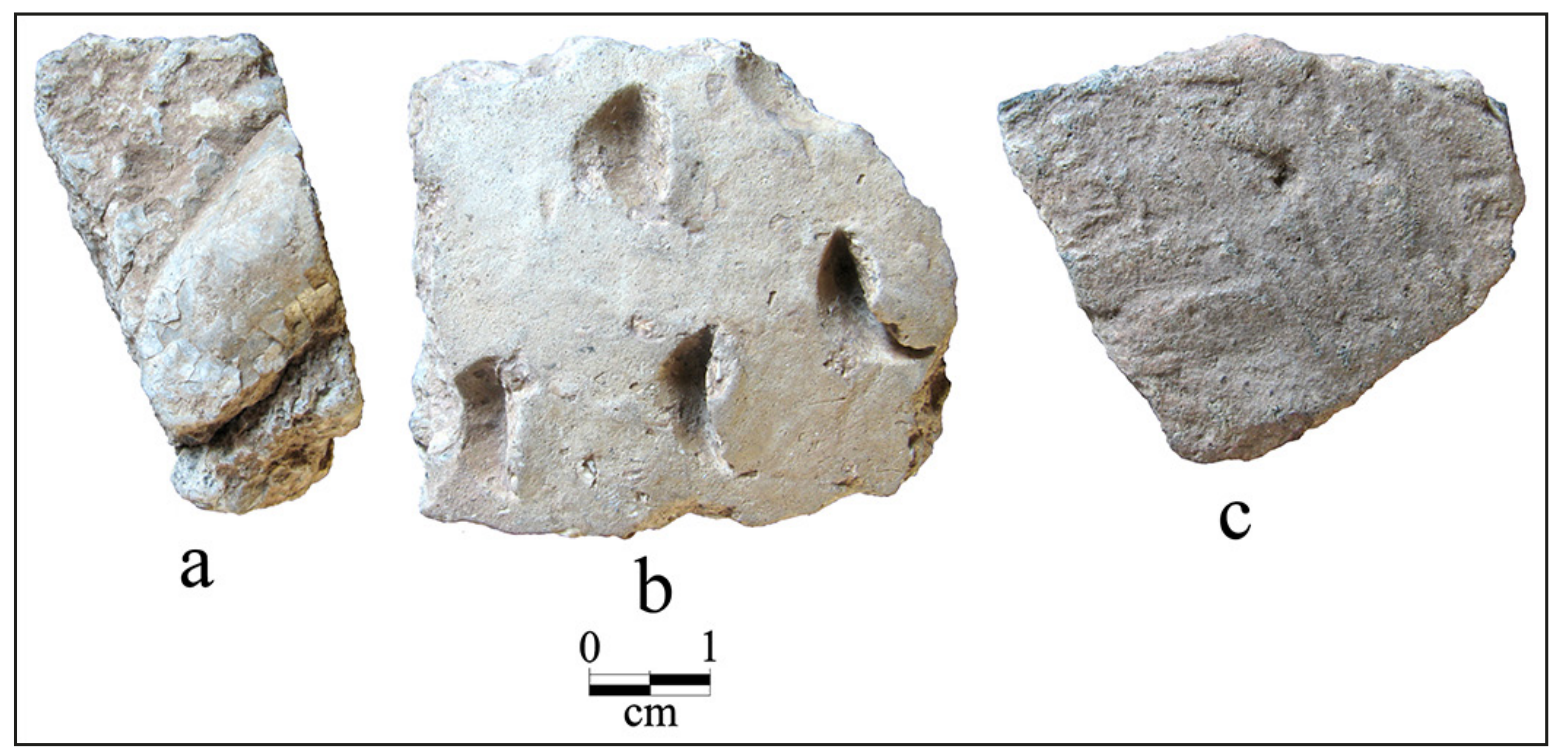

Figure 66. Selected decorated sherds from the Warner \#12 site in McLennan County, Texas. 
One of the fine ware sherds is from a Poynor Engraved bottle sherd with a set of curvilinear engraved lines above a straight engraved line with excised tick marks (Figure 67a). Another Poynor Engraved sherd has closelyspaced parallel engraved lines. A third engraved body sherd has horizontal and vertical engraved lines, while two grogtempered body sherds have a curvilinear engraved zone filled with hatched lines, and the other has sets of diagonal opposed engraved lines (Figure 67b); this latter sherd may be from a regional variety of Poynor Engraved (see Perttula 2011:Figure 6-65).

The decorated Caddo sherds in the assemblage from the Warner \#12 site

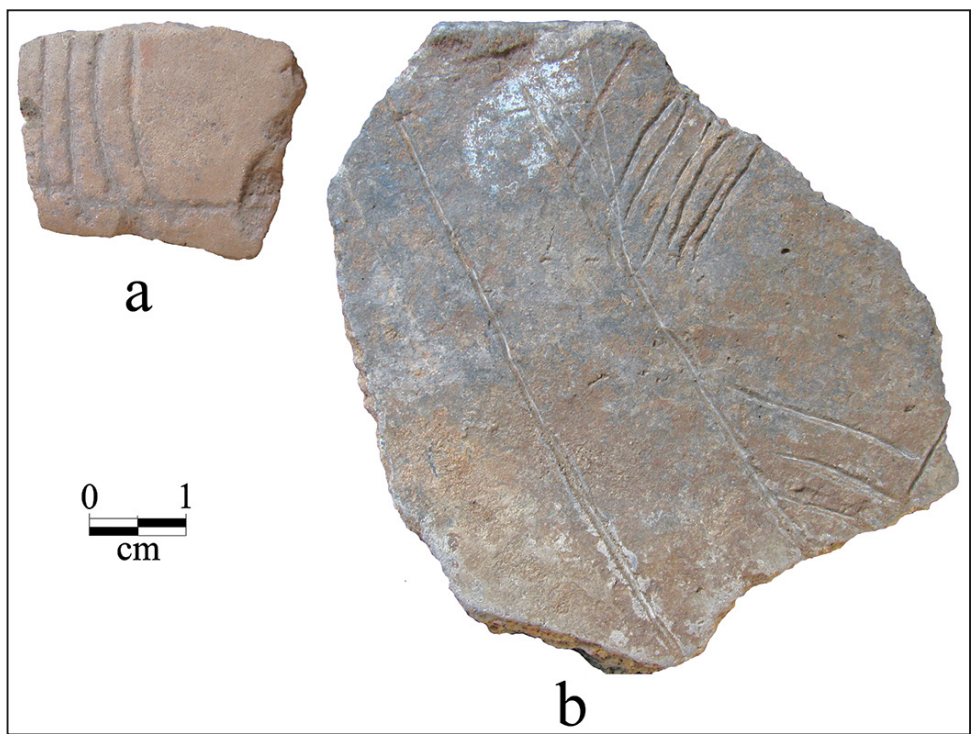

Figure 67. Engraved sherds from the Warner \#12 site in the Mayborn Museum Complex collections. are primarily from Frankston phase (ca.

A.D. 1400-1680) engraved, brushed, and incised vessels. These levels were likely made by Caddo potters living in communities in the upper Neches River basin. The one Crockett Curvilinear Incised rim sherd in the assemblage is indicative of some use of the site prior to ca. A.D. 1200, and it was perhaps occupied at about the same time as the nearby Asa Warner site (see Turner 1997).

\section{Mass Burial Site (No. Trinomial)}

This site, found near the Waco Sewage Disposal Plant, has an engraved ceramic ear spool of likely Caddo manufacture, as well as Perdiz arrow points (Meroney 1936:Figure 6:1). Th ear spool is decorated with a central engraved circle or dot that has six radiating engraved lines.

\section{Watt's Sites No.9, 13, and 21}

Sites No. 9 and No. 21 ( $\mathrm{n}=8$ sherds) are on Aquilla Creek in northern McLennan County (Watt 1953:Figure 26). According to Watt, these sherds are from Frankston phase vessels, although he does not indicate the kinds of decorations or types represented in the assemblages from these sites. Site No. 13, the Gas Bridge site, is on the Brazos River, just south of the city of Waco in the early 1950s. The two ceramic sherds found were described as Bullard Brushed (Watt 1953:84).

Also found at the site were glass trade beads (Watt 1953:84). It is possible that the Gas Bridge site is the same as the Gas Plant site excavated by Jensen (1967:45-50) for the Pilot Study of Wichita Indian Archeology and Ethnohistory, as the Gas Plant site was about 2 miles below the center of the City of Waco, and sat between the Brazos River and highway and railroad overpasses. In Jensen's work, no ceramic vessel sherds were recovered from the site (Jensen 1967:47). 


\section{K. H. Aynesworth Collection}

This accessioned collection in the Mayborn Museum Complex has only a general McLennan County provenience. There are 36 ceramic sherds from likely Late Caddo period Frankston phase ceramic vessels in this collection, including sherds from plain ware (55.6 percent), utility ware (38.9 percent), and fine ware (5.6 percent) (Table 52).

Table 52. K. H. Aynesworth Collection from McLennan County, Texas.

\begin{tabular}{lllll}
\hline Ware & $\begin{array}{l}\text { grog } \\
\text { tempered }\end{array}$ & $\begin{array}{l}\text { grog-bone } \\
\text { tempered }\end{array}$ & $\begin{array}{l}\text { bone } \\
\text { tempered }\end{array}$ & $\mathrm{N}$ \\
\hline Plain & $16^{*}$ & 2 & 2 & 20 \\
Utility & 10 & 3 & 1 & 14 \\
brushed & 2 & - & - & 2 \\
brushed-incised & 2 & - & - & 2 \\
incised & 3 & 2 & 1 & 6 \\
punctated & 3 & 1 & - & 4 \\
Fine & 1 & - & 1 & 2 \\
engraved & 1 & 5 & 4 & 36 \\
\hline Totals & 27 & & & 2 \\
\hline
\end{tabular}

*includes one sherd from a carinated bowl

These sherds are primarily from vessels tempered with grog ( 88.9 percent), but a significant percentage of the sherds ( 25 percent) are from vessels with either grog and bone temper or solely tempered with burned bone (see Table 52). More than 31 percent of the sherds with decorative elements are from vessels that have grog temper.

Among the utility ware sherds, more than 42 percent have incised decorative elements. This includes a body sherd from a Maydelle Incised jar with vertical and diagonal incised lines, another with vertical incised lines, as well as sherds with parallel incised lines $(n=4)$. Sherds with brushing (parallel and overlapping marks) and parallel brushed-incised marks and lines comprise 25 percent of the decorated sherds in the collection, and 28.6 percent of the utility wares; these sherds are likely from Bullard Brushed vessels. The punctated sherds have rows of either fingernail $(n=2)$ or tool $(n=2)$ marks on vessel body sherds.

One bone-tempered body sherd has a single straight engraved line. The other, from a grog-tempered Poynor Engraved vessel, has curvilinear engraved zones filled with diagonal hatched lines (see Suhm and Jelks 1962:Plate 63h-j),

\section{Elmer and Maude Hawkins Collection-Charles Pierce Farm}

This site in the community of Mount Pleasant in McLennan County has three Caddo vessel sherds from three different grog-tempered Late Caddo period vessels. The first sherd has parallel appliqued fillets with a row of tool punctations between the fillets, while the second sherd has closely-spaced parallel appliqued ridges, possibly from a Cass Appliqued jar (Suhm and Jelks 1962:Plate 13). The third sherd has parallel brushing marks. Taken together, the decorated sherds suggest an occupation that well post-dates A.D. 1400. 


\section{Elmer and Maude Hawkins Collection-Camp 3 on Navasota}

Only a single plain grog-tempered body sherd from a Caddo vessel is in the Camp 3 collection in the Navasota River basin.

\section{Elmer and Maude Hawkins Collection-Fadul Farm}

The Fadul Farm is on the North Bosque River in McLennan County, a few miles from its confluence with the Brazos River. There are 15 sherds from the site in the Mayborn Museum Complex; all the sherds are from grog-tempered vessels. Ten of the sherds are undecorated, including two body sherds from bottles. The five decorated sherds have parallel incised lines $(n=2)$ as decorative elements, parallel incised lines adjacent to a tool punctated row (probably from a Canton Incised or Maydelle Incised vessel) $(n=1)$, tool punctated row $(n=1)$, and a body sherd with opposed engraved lines.

\section{Elmer and Maude Hawkins Collection-Gene's Farm, Navasota Creek}

This collection has three grog-tempered plain body sherds. One of the sherds is from a carinated bowl, and accordingly is clearly of Caddo manufacture.

\section{Elmer and Maude Hawkins Collection-Hughes on Aquilla Creek}

There are 23 Caddo ceramic sherds in this collection at the Mayborn Museum Complex. Most are from grog-tempered vessels (82.6 percent), but four plain ware sherds (17.4 percent) have both grog and bone temper (Table 53). This is probably the Chupik site (41ML44), previously discussed, since Frank Watt campsite designations referred to it as the Chupek-Hughes site on Aquilla Creek.

Table 53. Caddo ceramic sherds from the Hughes site on Aquilla Creek, McLennan County, Texas.

\begin{tabular}{llll}
\hline Ware & grog-tempered & grog-bone-tempered & $\mathrm{N}$ \\
\hline Plain & 14 & 4 & 18 \\
Utility & 4 & - & 4 \\
$\quad$ appliqued & 1 & - & 1 \\
$\quad$ incised & 3 & - & 3 \\
Fine & 1 & - & 1 \\
$\quad$ engraved & 1 & - & 1 \\
\hline Totals & 19 & 4 & 23 \\
\hline
\end{tabular}

The utility wares include two body sherds with parallel incised lines, and another body sherd (probably from a Dunkin Incised vessel) with a set of vertical incised lines above a single horizontal incised line that ran at the rim-body juncture. The one fine ware sherd has only a single straight engraved line.

\section{Elmer and Maude Hawkins Collection-White Rock Creek}

White Rock Creek is a southern-flowing tributary to the Brazos River. The collection from the site at the Mayborn Museum Complex includes only a single grog-tempered base sherd. This is from an ancestral Caddo vessel made sometime after ca. A.D. 900. 


\section{Medina County}

\section{Tarpley (41ME147)}

Caddo ceramic vessel sherds were recovered in the Toyah phase midden in Area 4 (Thomas R. Hester, February 2017 personal communication). This includes a fingernail-punctated body sherd (Figure 68) and rim sherds from Vessel 3 with sets of horizontal and vertical incised lines (Figure 69). This midden may have been in use as late as the early $18^{\text {th }}$ century given the recovery of at least three Guerrero arrow points in Area 4. A conventional radiocarbon age of $560 \pm 15$ B. P. (UCIAMS TS 71-4) was also obtained from bison bone in the Area 4 archaeological deposits, but Thomas R. Hester (December 11, 2017 personal communication) suggests that the deposits "actually dated ca. 1710 or so because of 2 or 3 Guerrero points."

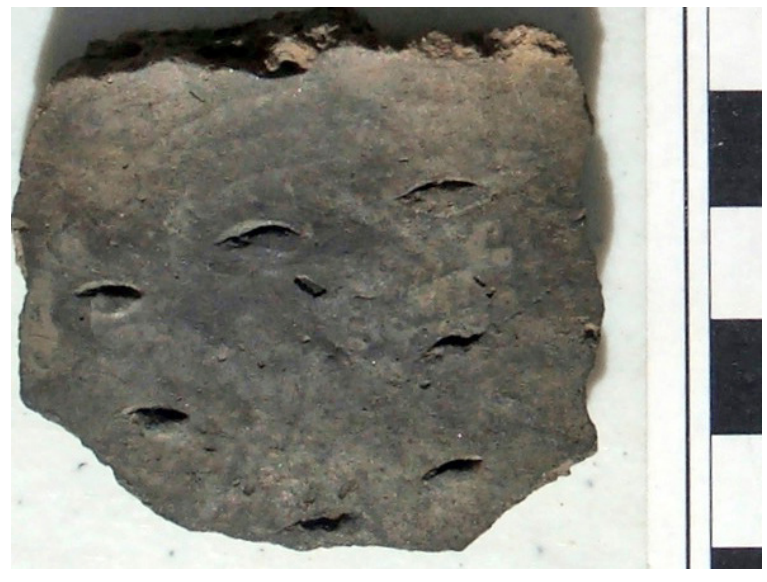

Figure 68. Fingernail punctated sherds from the Tarpley site (41ME147).

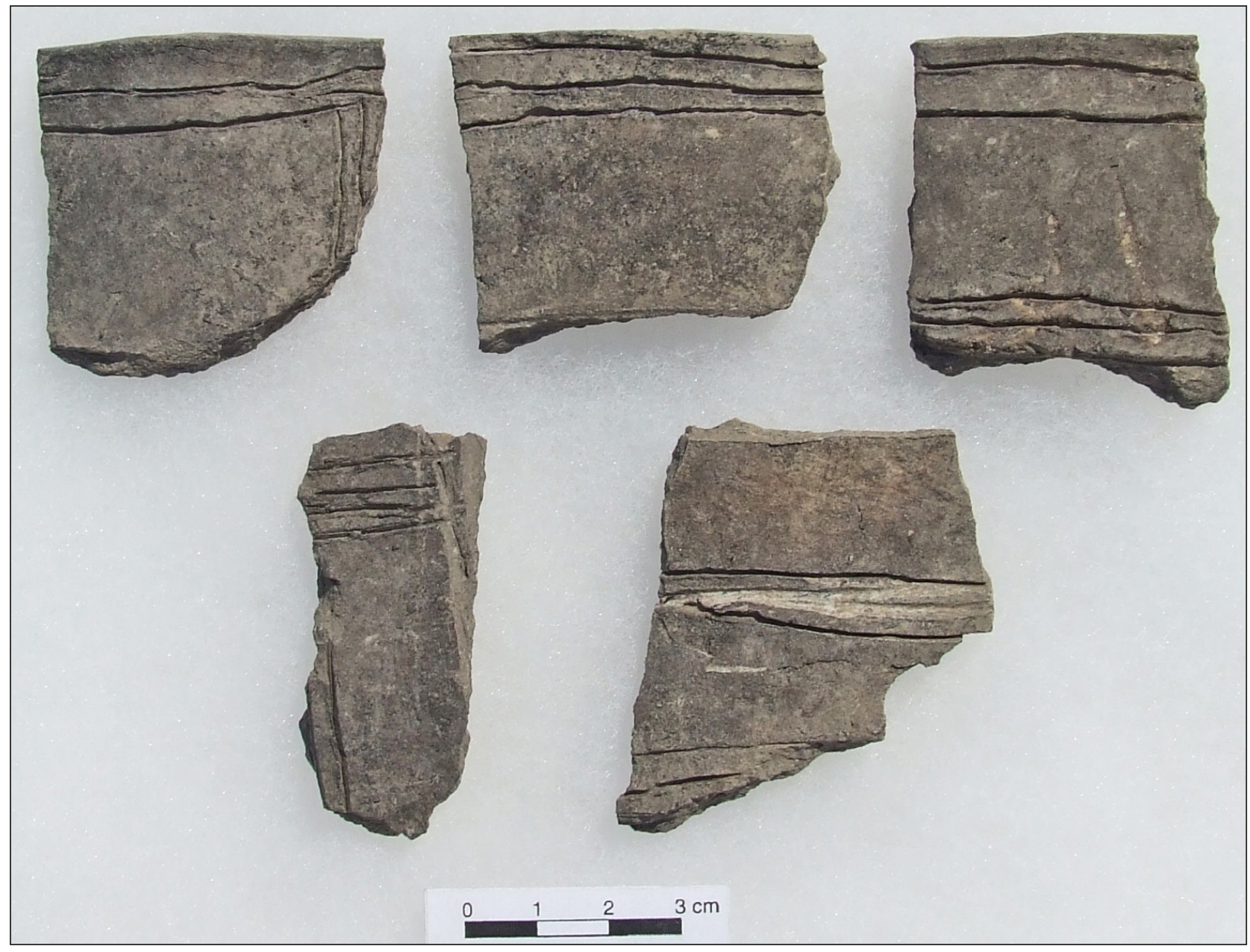

Figure 69. Horizontal and vertical incised sherds from Vessel 3 at the Tarpley site (41ME147). 


\section{Milam County}

\section{$41 M M 341$}

A total of 13 ceramic sherds from 41MM341 on the Little River were examined by Perttula (2001) during test excavations at the site. They are in a prehistoric component estimated to date about cal. A.D. 1010-1190 (Mahoney and Tomka 2001:50 and Table 7-13).

The sherds are from two vessels. The first vessel ( $\mathrm{n}=11$ undecorated sherds) has finely crushed and burned bone temper inclusions, and it has been fired in a reducing environment (see Teltser 1993:Figure 2B). The sherds are from the body of a thick-walled vessel, probably a jar; the body wall thickness ranges from 6.9-9.4 $\mathrm{mm}$, with a mean of $8.8 \pm 0.6 \mathrm{~mm}$. Two of the body sherds have a smoothed exterior surface, and one has remnants of an organic residue from use of the vessel for cooking foodstuffs.

The second vessel has two sherds from a carinated bowl with bone and grog temper, and the clay paste is sandy. The carinated bowl had been fired in a reducing environment and cooled in a high oxygen environment (see Teltser 1993:Figure 2F). Body wall thickness ranges from 7.9-8.4 mm, with a mean of $8.15 \pm 0.25 \mathrm{~mm}$. One of the carinated bowl sherds has a single broad horizontal incised line above the carination, and it is likely that the decorative element consists of multiple horizontal incised lines on the rim of the vessel.

The limited amount of bone in the paste of both vessels (less than 10 percent of the paste), the thick body walls, and the absence of well-burnished exterior and interior surfaces indicates that the first vessel is not from a post-A.D. 1250 Leon Plain vessel. Whether it is a locally-made vessel is unknown, although this seems a reasonable conclusion. The occurrence of grog in the incised carinated bowl strongly suggests that this vessel was made in the East Texas Caddo area. Grog temper is widely used in Caddo vessels of all time periods, and the carinated bowl form also appears to be a Caddo innovation in East Texas (see Perttula 2013), and throughout the Caddo area.

During the data recovery work, four additional ceramic sherds were recovered from a component that Gadus et al. (2006:136) suggest may date from the early $15^{\text {th }}$ century. However, since the main component is estimated by Gadus et al. (2006:136) to date from ca. A.D. 900-1300, and Mahoney and Tomka (2001) argue that the principal component dates from cal. A.D. 1010-1190, it seems reasonable to suggest that the ceramic sherds from both phases of work belong with this component; the one decorated ancestral Caddo vessel sherd is of no help in establishing more specifically the age range of this component.

The sherds found in the data recovery work are either bone-tempered or simply have a sandy paste with no temper. Gadus et al. (2006:125) suggest that "ceramics are so sparse [at the site] that it is clear that ceramic vessels did not play any significant role in activities performed at the site." Gadus et al. (2006:177) go on to suggest that the Caddo style ceramics found at 41MM341 are likely the product of "local groups interacting with east Texas Caddo groups through trade, marriage, or visitation." These sherds, as well as the thick bone-tempered plain ware sherds found during the test excavations, appear to have been made by a local Little River group and do not represent Caddo vessels. Only the bone-grogtempered carinated body sherds from one vessel decorated with incised lines is considered to be of Caddo manufacture. 


\section{Victor Turner Collection}

The Victor Turner collection from an unrecorded site in Milam County has three lower rim and body sherds from an ancestral Caddo vessel with incised decorative elements (Figure 70). The lower part of the rim has incised triangles filled with incised lines pitched in opposite directions, and the upper part of the vessel body has horizontal incised lines. These sherds are from an Early Caddo period Dunkin Incised vessel (see Suhm and Jelks 1962:Plate 19b).

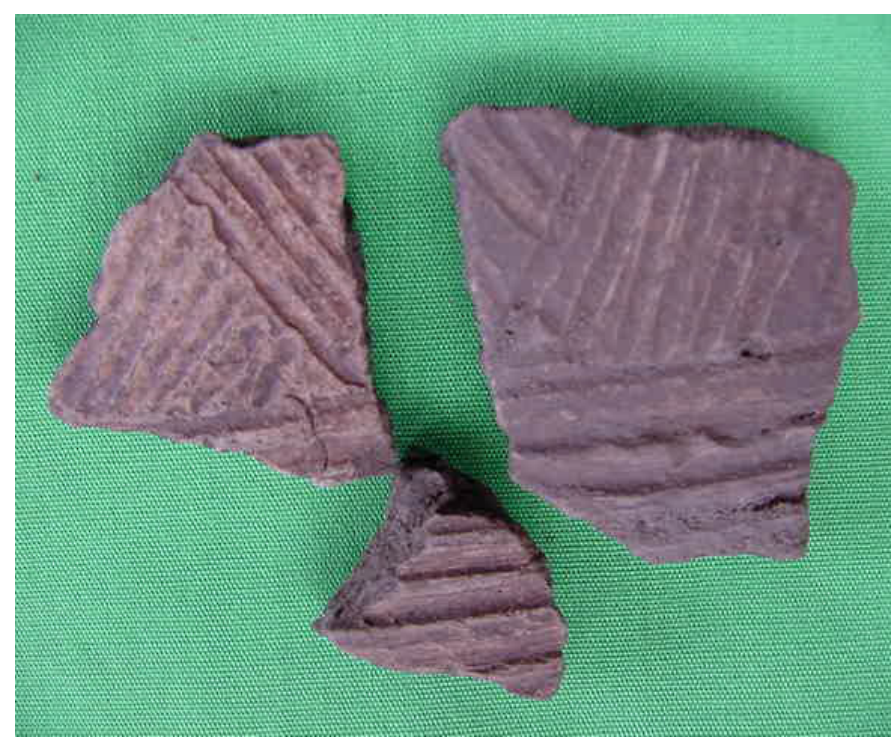

Figure 70. Lower rim and body sherds from a Dunkin Incised vessel in the Victor Turner collection from Milam County. Photograph courtesy of Thomas R. Hester.

\section{Mills County}

\section{Trotter site (41MI4)}

The Trotter site (41MI4) is located in the Colorado River basin in the Lampasas Cut Plain. There are five burned rock middens present there, along with a rock shelter. Ancestral Caddo ceramic vessel sherds $(n=24)$ have been recovered from a surface collection at the site, along with two Leon Plain sherds (Saylor 1974:22). The same surface collection is dominated by Scallorn arrow points, suggesting that the Caddo sherds may be from a pre-A.D. 1200 occupation at the site, though the presence of Perdiz arrow points and Leon Plain ceramic vessel sherds points to the use of the site during the post-A.D. 1200 Toyah phase.

The illustrated Caddo ceramic rim and body sherds are from a jar that has horizontal and vertical rows of fingernail punctations (Saylor 1974:Illustration XI), including a horizontal row of punctations just below the vessel lip. These sherds may be from the same vessel, although Saylor (1974) did not provide any information on their temper or firing conditions. 


\section{Nolan County}

\section{Roby 4:5 (41NL19)}

This site investigated by E. B. Sayles in the early 1930s has both Toyah phase Leon Plain ceramic sherds as well as ancestral Caddo vessel sherds. The latter include two plain grog-tempered body sherds and a grog-tempered body sherd from a jar with two or more tool punctated rows.

\section{San Saba County}

\section{Fall Creek No. 2 (41SS2)}

Jackson (1938:110-111) recovered 78 ceramic sherds from this site at Lake Buchanan on the Colorado River. Most of these sherds ( $n=61$ or 78 percent) were identified as originating in East Texas Caddo sites, specifically in sites occupied by ancestors of the Hasinai Caddo in the Neches-Angelina river basins. They came from primarily $15-30 \mathrm{~cm}$ bs in Midden No. 1 (Jackson 1938:45). Midden No. 2 at this site had another 28 ceramic vessel sherds (Jackson 1938:49), and Shelter No. 2 had one sherd (Jackson 1938:53). Decorations on these sherds were described by Jackson (1938:112) as having "incised and raised designs, some of which were identical with certain pottery decoration in East Texas."

The TARL collections from Midden 1 at the Fall Creek No. 2 site (41SS2) have both Toyah phase Leon Plain bone-tempered ceramics as well as two ancestral Caddo ceramic sherds. One is a bone-tempered body sherd with parallel brushing marks (INAA, UT00297), likely from a Bullard Brushed vessel made in the Angelina, Neches, or mid-Sabine River basins in East Texas (see Perttula 2015a:Figure 11). The other is a plain grog-tempered jar sherd.

\section{Finis Frost (41SS20)}

A single plain grog-tempered body sherd of possible ancestral Caddo origin is present in the small ceramic assemblage at the Finis Frost site, a Toyah phase component on Richland Springs Creek in the Colorado River basin (Green and Hester 1973:81, 83). The sherd is described as smudged on the exterior surface, light brown on the interior surface, and ranges from 4.0-7.0 $\mathrm{mm}$ in thickness. Green and Hester (1973:81) note that grog-tempered sherds have been identified in sites at the nearby Robert Lee Reservoir on the Colorado River (Shafer 1969:71).

\section{$41 S S 28 / 177$}

This Toyah phase site is on an alluvial terrace of the San Saba River, and has an ancestral Caddo ceramic vessel sherd with parallel incised lines (Figure 71, INAA, UT00385) (Prikryl et al. 2010:178179). This sherd is likely from a Maydelle Incised vessel. Another grog-tempered sherd with a straight incised line (INAA, UT00378) is in the TARL collections. Buddy Whitley has also recovered a plain grog-tempered body sherd from the site (Figure 72a-b). Charles Hixson (July 2017, personal communication) also reports that a brushed sherd has been recovered at an unrecorded site about $1.6 \mathrm{~km}$ downstream from 41SS28/177. 


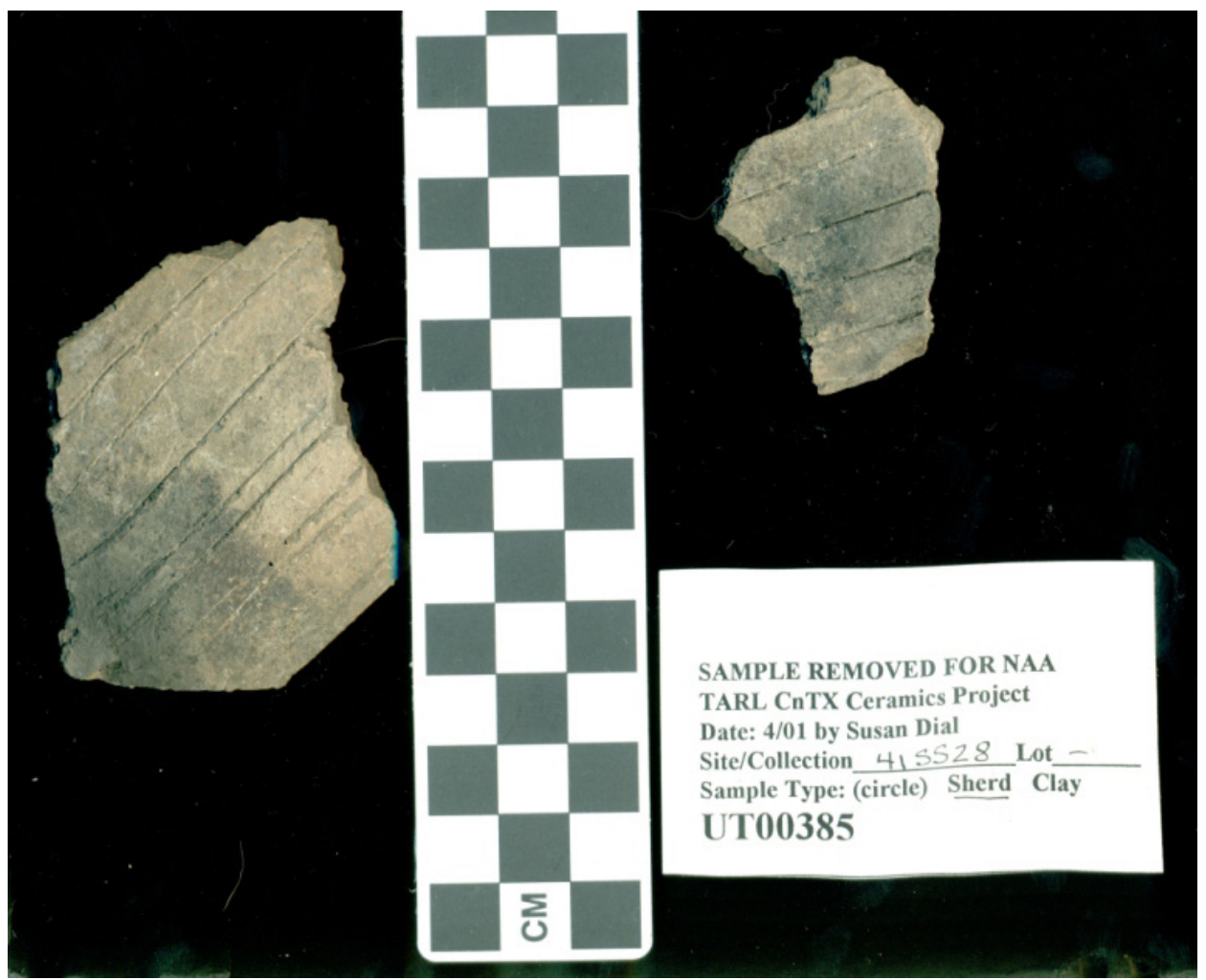

Figure 71. Incised sherd from 41SS28/177.
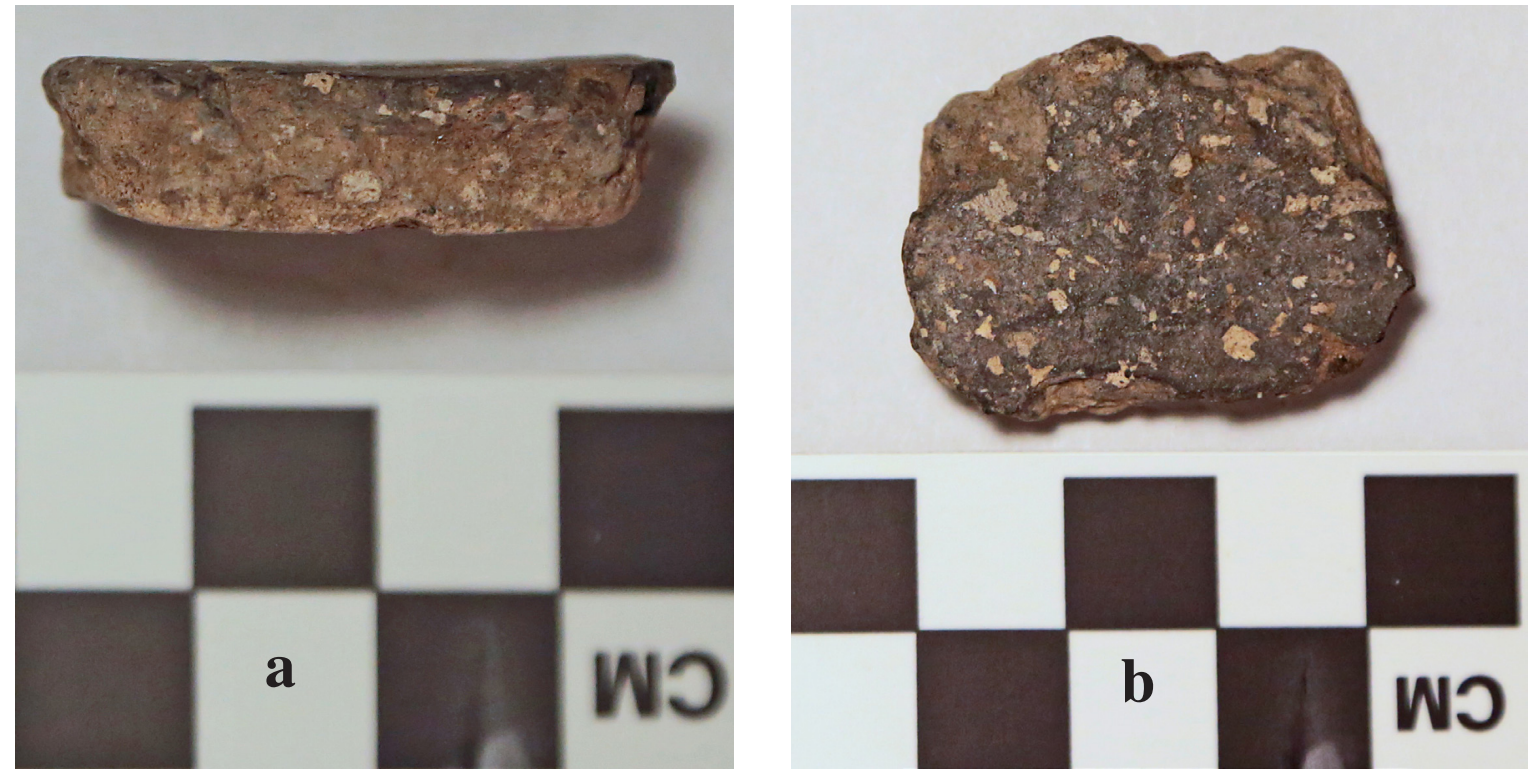

Figure 72. Plain grog-tempered body sherd from 41SS28/177: a cross-section; b, vessel sherd surface.

\section{Baker (41SS192)}

A bone-tempered brushed sherd from an ancestral Caddo vessel has been found at the Baker site (41SS192) during excavations by the Llano Uplift Archeological Society (Charles Hixson, July 2017 
personal communication). The Baker site is a large Toyah phase encampment on the San Saba river. A Cuney arrow point, associated with Historic Caddo sites in the Neches-Angelina river basins in East Texas (Perttula and Marceaux 2018:Table 8), was found in the same unit and level as the brushed vessel sherd.

Continued excavations by the Llano Uplift Society in 2017 has recovered additional Caddo ceramic vessel sherds in the archaeological deposits at the Baker site, in association with bone-tempered Leon Plain sherds, and I have had an opportunity to look at a sample of the sherds $(n=23)$ for this project. According to Hixson (January 2018 personal communication), work at the site has recovered 70 sherds from the surface, shovel tests, and 1 x 1 m units. The density of ceramic vessel sherds $(n=57)$ in the excavations is a low 1.84 sherds per square meter.

In the sample of 23 ceramic vessel sherds I examined from the Baker site, 10 are body sherds from bone-tempered Leon Plain vessels. Based on differences in firing conditions and body wall thickness, these body sherds are from at least six different vessels. The other $13 \mathrm{rim}$, body, and base sherds in the sample are from grog, grog-bone, and bone-tempered Caddo vessels that were found on the surface, in ST 18 (40-60 cm bs), and in a number of units (Units 7, 10, 18, 22, 23, 28, and 31); the sherds in the units came from $5-25 \mathrm{~cm}$ bs (Table 54). The area of the site that has ancestral Caddo ceramic vessel sherds is at least 3 acres in size (Charles Hixson, January 2018 personal communication).

Table 54. Caddo ceramic vessel sherds from the Baker site (41SS192).

\begin{tabular}{|c|c|c|c|c|c|c|}
\hline $\begin{array}{l}\text { Context } \\
\text { (and } \mathrm{cm} \mathrm{bs} \text { ) }\end{array}$ & $\begin{array}{l}\text { sherd } \\
\text { type }\end{array}$ & temper & ST & $\mathrm{FC}$ & $\begin{array}{l}\text { Th } \\
(\mathrm{mm})\end{array}$ & Decoration \\
\hline Surface & body & grog-bone & - & $\mathrm{B}$ & 5.1 & parallel brushed \\
\hline Surface & rim & bone & $\begin{array}{l}\mathrm{I} / \mathrm{E} \\
\mathrm{SM}\end{array}$ & $\mathrm{F}$ & 5.6 & $\begin{array}{l}\text { diagonal and opposed } \\
\text { engraved lines }\end{array}$ \\
\hline ST $18,40-60$ & body & grog & E SM & $\mathrm{F}$ & 7.9 & plain \\
\hline Unit $7,5-10$ & body & grog & I SM & $\mathrm{B}$ & 6.5 & parallel brushed \\
\hline $\begin{array}{l}\text { Unit } 10,10- \\
\quad 15\end{array}$ & body & grog & $\begin{array}{l}\mathrm{I} / \mathrm{E} \\
\mathrm{SM}\end{array}$ & $\mathrm{B}$ & 6.3 & plain \\
\hline Unit $18,5-10$ & body & bone and grog & $\begin{array}{l}\mathrm{I} / \mathrm{E} \\
\mathrm{SM}\end{array}$ & $\mathrm{G}$ & 7.9 & plain \\
\hline Unit $18,5-10$ & body & grog and bone & - & $\mathrm{G}$ & 8.7 & plain \\
\hline $\begin{array}{l}\text { Unit } 22,20- \\
\quad 25\end{array}$ & body & grog-bone & - & $\mathrm{B}$ & 9.1 & $\begin{array}{l}\text { row of fingernail. } \\
\text { punctations }\end{array}$ \\
\hline $\begin{array}{l}\text { Unit } 23,10- \\
\quad 15\end{array}$ & body & grog and bone & I SM & $\mathrm{G}$ & 8.1 & plain \\
\hline $\begin{array}{l}\text { Unit } 23,10- \\
\quad 15\end{array}$ & base & grog & $\begin{array}{l}\mathrm{I} / \mathrm{E} \\
\mathrm{SM}\end{array}$ & $\mathrm{G}$ & 12.5 & plain \\
\hline Unit $28,5-10$ & body & bone & - & $\mathrm{F}$ & 7.1 & parallel brushed \\
\hline $\begin{array}{l}\text { Unit } 28,10- \\
15\end{array}$ & body & grog & $\begin{array}{l}\mathrm{I} / \mathrm{E} \\
\mathrm{SM}\end{array}$ & B & 8.1 & plain \\
\hline $\begin{array}{l}\text { Unit } 31,15- \\
20\end{array}$ & body & grog-bone & E B & $\mathrm{F}$ & 4.8 & $\begin{array}{l}\text { engraved element } \\
\text { on bottle }\end{array}$ \\
\hline
\end{tabular}

ST=surface treatment: $\mathrm{I}=$ interior surface; $\mathrm{E}=$ exterior surface; $\mathrm{B}=$ burnished; $\mathrm{SM}=$ smoothed $\mathrm{FC}=$ firing conditions; $\mathrm{B}=$ fired and cooled in a reducing environment; $\mathrm{F}-\mathrm{G}=$ fired in a reducing environment and cooled in the open air; Th=thickness 
The 13 sherds from ancestral Caddo ceramic vessels include one rim sherds, 11 body sherds, and one base sherd. They are from vessels tempered with grog $(n=5)$, grog-bone $(n=6)$, and bone $(n=2)$ ( see Table 54). Seven of the sherds have no decoration, while the other six are from either brushed $(n=3)$ and fingernail punctated $(n=1)$ utility wares, or are from fine wares with engraved $(n=2)$ decorative elements.

Most of the Caddo ceramic vessel sherds have been smoothed on one or both vessel surfaces (see Table 54); one engraved bottle sherd has been burnished on its exterior surface. All of the sherds are from vessels fired in a reducing or low oxygen environment, and 61 percent are from vessels that were subsequently cooled in the open air.

The one Caddo vessel rim is $5.6 \mathrm{~mm}$ in thickness. Body sherds range from 4.8-9.1 $\mathrm{mm}$ in thickness, indicating that different vessel forms and/or sizes are represented in the assemblage of Caddo vessel sherds from the Baker site. The one base sherd is thick $(12.5 \mathrm{~mm})$ and has a flat disk shape.

Three of the decorated Caddo vessel sherds at the Baker site have parallel brushing marks on the vessel body (see Table 54); these are from Late Caddo period Bullard Brushed jars. Another body sherd has a single row of fingernail punctations. The remaining two decorated sherds are from engraved fine ware vessels. The first is a bone-tempered rim that has diagonal and opposed engraved lines, and the second is a body sherd from a bottle. This sherd has a vertical engraved line, probably part of a vertical panel, with diagonal opposed engraved lines to either side of the vertical line (Figure 73). The sherd is probably from either a Hume Engraved or Poynor Engraved bottle with an elongated body and a short neck (see Suhm and Jelks 1962:Plates 42a-c, e and 63a-g). Such vessels were made in the Neches/ Angelina river basins in East Texas from ca. A.D. 1400 to at least ca. A.D. 1680, and the sherd from the engraved bottle at the Baker site originated in that area (as did the Bullard Brushed jar sherds); Hume Engraved vessels were most commonly manufactured after ca. A.D. 1560, at least in the upper Neches River basin (see Perttula 2011).

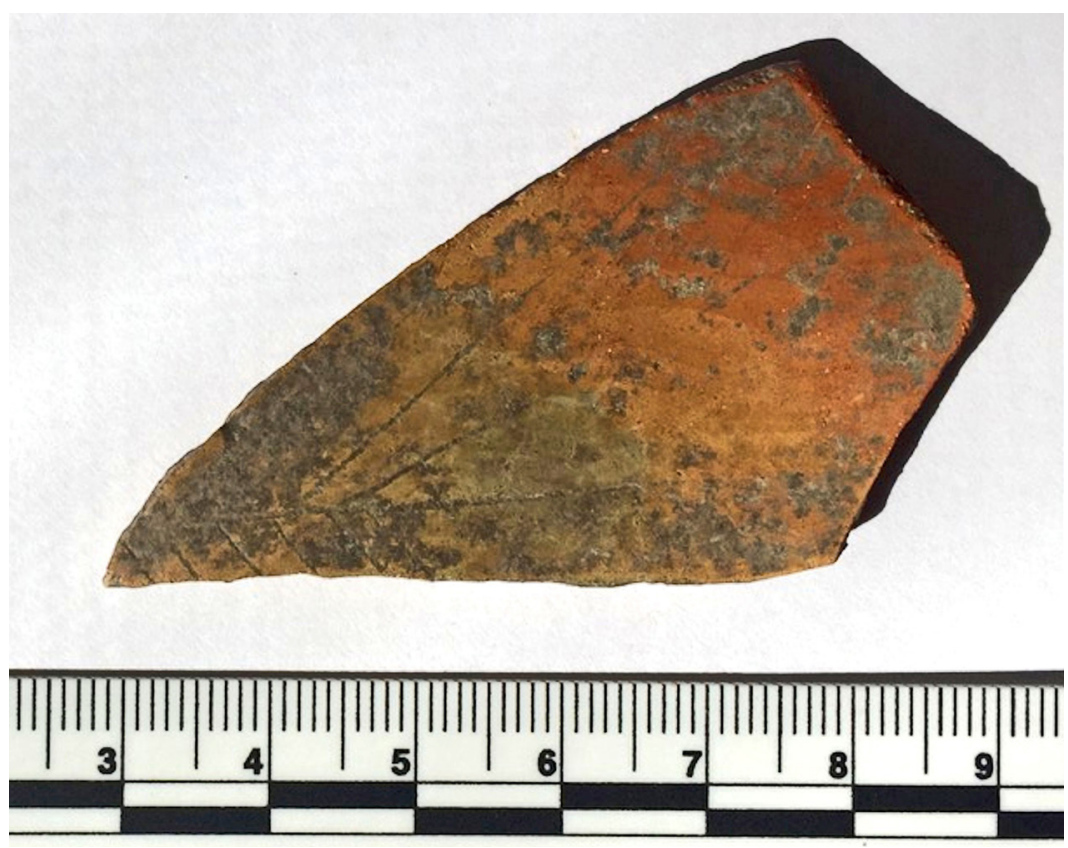

Figure 73. Engraved bottle sherd from the Baker site (41SS192). Photo provide courtesy of Charles Hixson. 


\section{Sterling County}

\section{The Davis Hackberry Spring Site (41ST87)}

Apparently several thousand ceramic sherds - of unknown types - have been collected from the Toyah phase component at the Davis Hackberry Spring site (41ST87) (Riemenschneider 1996:17). Among them are several brushed Caddo jar sherds (Eric Schroeder, 2016 personal communication).

\section{Taylor County}

\section{Abilene 4:13 (41TA123)}

Leon Plain sherds from a Toyah phase occupation at this site are abundant, but there are a number of ancestral Caddo sherds in the TARL collections that are tempered almost exclusively with grog inclusions (Table 55). One incised utility ware sherd has bone temper.

Table 55. Ancestral Caddo ceramic vessel sherds from 41TA123.

\begin{tabular}{lllcc}
\hline Ware & Grog-tempered & $\begin{array}{l}\text { Grog-tempered/ } \\
\text { sandy paste }\end{array}$ & Bone-tempered & $\mathrm{N}$ \\
\hline Plain ware & 18 & 2 & - & 20 \\
Utility ware & 42 & - & 1 & 43 \\
Fine ware & 1 & - & - & 1 \\
\hline Totals & 61 & 2 & 1 & 64 \\
\hline
\end{tabular}

The collection of ancestral Caddo sherds is dominated by utility wares, including appliqued $(\mathrm{n}=1)$, brushed ( $n=25$, INAA, UT00269 and UT00270), incised ( $n=15)$, incised-punctated $(n=1)$, tool punctated $(n=1)$, and one fine ware sherd has an engraved element. The appliqued body sherd has a single straight appliqued ridge, while the brushed sherds have horizontal or vertical brushed marks on rims and parallel brushing marks on body sherds. The sherds with incised elements have broad horizontal incised lines on rims, and parallel or straight incised lines on body sherds. The one incised-punctated sherd has horizontal incised lines with diagonal linear tool punctations (Figure 74a). The one engraved sherd is from a bottle, and has a portion of an engraved snake head element (Figure 74b). Engraved snake elements are found on a wide range of ancestral Caddo sites in the Sabine and NechesAngelina river basins in East Texas, primarily dating to the Middle Caddo period (ca. A.D. 1200-1400) (Hart 2014; Walters 2006). The frequency of brushed sherds among the decorated Caddo sherds in the assemblage (55 percent) is consistent with East Texas Caddo pottery assemblages dating after ca. A.D. 1300-1400.

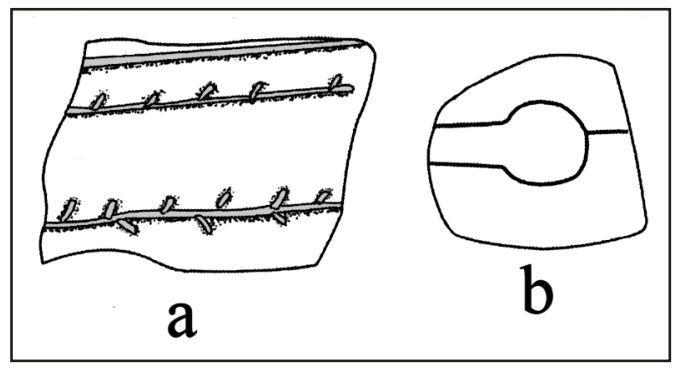

Figure 74. Selected decorative elements on ancestral Caddo ceramic sherds from 41TA123. 


\section{$41 T A 124$}

There are two ancestral Caddo ceramic vessel sherds in the TARL collections from the site. One is a plain grog-bone-tempered body sherd (INAA, UT00214), and the other is a grog-tempered Bullard Brushed body sherd (INAA, UT00213) with parallel brushing marks and a tool punctated row pushed through the brushing.

\section{$41 T A 125$}

This site has two ancestral Caddo grog-tempered sherds in the TARL collections, probably dating to Historic Caddo times. The first sherd is a Lindsay Grooved body sherd with parallel grooved lines and opposed incised lines; this type of ceramics was made after ca. A.D. 1680 in the Neches-Angelina River basins in East Texas (see Marceaux 2011). The other is a grog-tempered body sherds with parallel brushed-incised marks and lines, probably from a Bullard Brushed vessel.

\section{Steadman \#31 (41TA186)}

A single plain grog-tempered body sherd of probable ancestral Caddo manufacture is in the TARL collections from 41TA186 (INAA, UT00233).

\section{Tom Green County}

\section{$41 T G 45$}

There are Leon Plain sherds in the ceramic sherd assemblage from 41TG45 as well as two ancestral Caddo sherds; the site is on the South Concho River not far from 41TG91 (Creel 1990:143, and see below). One is a grog-tempered body sherd with parallel brushing marks (Bullard Brushed, INAA UT00059) and the other is a grog-tempered Historic Caddo Patton Engraved body sherd (INAA, UT00054) with parallel engraved lines and excised tick marks (Figure 75). Creel (1990:143; see also Creel et al. 2013:75) notes that there are several sherds from Patton Engraved vessels in the assemblage, as well as at least two other engraved vessels and another vessel with incised decorative elements. Creel (1990:143) also further comments that the

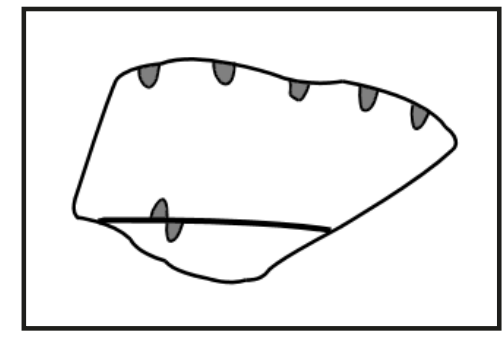

Figure 75. Decorative elements on Patton Engraved body sherd from 41TG45. larger sherd collections from Tom Green County sites have sherds:

from vessels with incised, engraved, punctated, and appliqued decorations; some of these compare favorably with pottery types from the Caddoan [sic] area in East Texas...[n]ot infrequently, the more common locally made ceramics occur with sherds from vessels closely resembling various Caddoan [sic] wares from East Texas.

\section{$41 T G 48$}

The TARL collections from this site on the South Concho River (Creel 1990:143) include both Leon Plain body sherds and ancestral Caddo ceramic sherds. These include a grog-bone-tempered body sherd with parallel incised lines (Maydelle Incised, INAA UT0048) and a bone-tempered body sherd with parallel brushing marks (Bullard Brushed, INAA UT0047). The Caddo sherds likely date to post-A.D. 1400 times and are associated with Caddo settlements in the Neches River basin in East Texas. 


\section{$41 T G 91$}

There is a large assemblage of ceramic vessel sherds at 41TG91 on the South Concho River, namely 447 sherds from at least 18 individual vessels. The ceramics are from the Toyah phase occupation at the site (Creel 1990:135). Likely ancestral Caddo ceramics at the site include seven sherds in Group 2 sherds with "straight engraved lines" are from what is presumed to be a bone-tempered olla (Creel 1990:136). One of the Group 8 sherds is decorated with a single incised line.

\section{Rush (41TG346)}

The Rush site has intact Toyah phase archaeological deposits dated to ca. A.D. 1575 (Quigg and Peck 1995:164). The 184 ceramic vessel sherds in Occupation 4 are from seven different vessels, one of which (Vessel 5) is a grog [clay-grit]-bone-tempered jar with parallel and overlapping brushing marks (Quigg and Peck 1995:Figure 5.46), likely a Bullard Brushed jar made by a Frankston phase Caddo potter. According to Quigg and Peck (1995:146), this vessel "has construction attributes that support an interpretation that it was manufactured by a woman other than those women forming the core female population of the Toyah group." This group made undecorated bone-tempered bowls and jars.

The one ancestral Caddo ceramic sherd from 41TG346 in the TARL collections is a grog-tempered body sherd with parallel brushing marks (INAA, UT00303). It is likely from a Bullard Brushed vessel.

\section{$41 T G 424$}

There is a single ancestral Caddo ceramic vessel sherd in the TARL collections from 41TG424. It is a grog-tempered body sherd from a Belcher Ridged jar with parallel ridge elements (INAA, UT00354). Belcher Ridged is a ceramic type manufactured on the Red River in northwest Louisiana and southwest Arkansas after ca. A.D. 1500 by Belcher phase Caddo potters.

\section{Ben M. Cox Collection (41TG541)}

This TARL collection has both Leon Plain bone-tempered sherds, a thicker plain bone-tempered ware, and six ancestral Caddo ceramic sherds from at least three separate vessels. One is a plain body sherd from a grog-tempered bottle, while four others have either parallel ( $\mathrm{n}=3$, INAA, UT00152) or horizontal ( $\mathrm{n}=10$ brushing marks. The horizontal brushed sherd is a rim sherd from a grog-tempered jar. The last ancestral Caddo sherd is from a grog-tempered vessel that has rows of fingernail punctations (INAA, UT00153).

\section{Travis County}

\section{Nancy Edwards Collection (41TV5)}

This collection from a site along the Colorado River in Montopolis, Texas, has a number of Toyah phase Leon Plain sherds $(\mathrm{n}=77)$, as well as a thicker bone-tempered ware of uncertain type with a sandy paste $(n=147)$. There is also a good bit of plain and decorated ancestral Caddo ceramic wares tempered with grog (93 percent), grog-bone ( 2 percent), or bone (4.8 percent) (Table 56$)$. 
Table 56. Ancestral Caddo ceramic vessel sherds from 41TV5.

\begin{tabular}{lllll}
\hline Ware & Grog-tempered & $\begin{array}{l}\text { Grog- } \\
\text { bone-tempered }\end{array}$ & Bone-tempered & $\mathrm{N}$ \\
\hline Plain ware & 32 & 1 & - & 33 \\
Utility ware & 7 & - & 2 & 9 \\
\hline Totals & 39 & 1 & 2 & 42 \\
\hline
\end{tabular}

The decorated sherds in the assemblage are from Caddo utility wares. They include bone-tempered sherds with parallel brushed marks and a Bullard Brushed body sherd with parallel brushed marks and a tool punctated row pushed through the brushing. The grog-tempered utility wares, one rim sherd and six body sherds, have the following decorative elements: a straight incised line; opposed incised lines (probably from a Maydelle Incised vessel); parallel brushed (INAA, UT00142); parallel brushed-incised marks and lines; a rim sherd with a row of fingernail punctations below the vessel lip; a body sherd with rows of fingernail punctations; and another body sherd with a linear row of tool punctations.

\section{$41 T V 29$}

One or two probable ancestral Caddo ceramic body sherds are in the TARL collections from 41TV29. The first sherd, bone-tempered, has a single tool punctate decorative element. Another body sherd, grogbone-tempered (INAA, UT00295), has horizontal brushing marks adjacent to a row of tool punctations. This sherd is likely from a Bullard Brushed jar.

\section{Collins (41TV40)}

The Collins site is on Onion Creek, only a few miles upstream from the confluence of Onion Creek and the Colorado River. Excavations reported by Suhm $(1955,1956)$ recovered 849 ceramic vessels from 0-18 inches bs in Toyah phase archaeological deposits. These sherds were sorted into Leon Plain (234 sherds from 2-5 vessels), including some bone-tempered sherds from thicker (6-10 mm) vessels (Suhm 1956:12). One of the bone-tempered sherds had a small appliqued node, and another had a loop handle. Two different sherds with a Leon Plain paste had incised decorative elements, and 613 sherds were from what was defined by Suhm as Boothe Brushed jars (Suhm 1956:Plates 1a-i and 2:ii-jj).

Boothe Brushed jars had either bone temper or no visible temper, were smoothed on their interior surfaces, had thin vessel walls $(3-7 \mathrm{~mm})$, everted rims, and flat lips. The jars were estimated to be between $18-25 \mathrm{~cm}$ in height and $14-18 \mathrm{~cm}$ in orifice diameter. Decorations on the jars included horizontal or vertical brushing on the rim, and horizontal or vertical brushing on the vessel body; 1-2 rows of tool punctations were placed at the rim-body juncture or below the lip, and there were vertical appliqued fillets on the body, as well as appliqued nodes just below the lip.

Suhm (1956:16) considered Boothe Brushed vessels as being of local manufacture by a Toyah phase group, primarily based on observed links to Leon Plain, in particularly their bone-tempered pastes; Creel et al. (2013) INAA findings appear to support their local Central Texas manufacture. Suhm (1956:16) did note the close similarity between Boothe Brushed and ancestral Caddo Bullard Brushed vessels, "but Boothe Brushed differs considerably in paste and somewhat in vessel shape, size, and mode of brushing. It is not Caddoan [sic] trade ware and probably was made at the Collins site." 
Recent examination of the ceramic vessel sherds from the Collins site does indicate that there are ancestral Caddo sherds in the assemblage, based both on the presence of grog temper in sherds as well as distinctive decorative elements on the sherds (Table 57). These 70 sherds are from grog-tempered (80.3 percent) and grog-bone-tempered (19.7 percent) vessels, almost exclusively utility wares.

Table 57. Ancestral Caddo wares at the Collins site (41TV40).

\begin{tabular}{llll}
\hline Ware & Grog-tempered & Grog-bone-tempered & $\mathrm{N}$ \\
\hline Plain & 1 & - & 1 \\
Utility & 55 & 14 & 69 \\
Fine & 1 & - & 1 \\
\hline Totals & 57 & 14 & 71 \\
\hline
\end{tabular}

The one plain grog-tempered body sherd (INAA, UT00114) is from a vessel that has been burnished on both interior and exterior surfaces, likely a bowl or carinated bowl. The one fine ware grog-tempered body sherd (probably from a carinated bowl) has a horizontal engraved line and several connecting diagonal engraved lines; the typological identification is undetermined. The ancestral Caddo identified utility wares at the Collins site are almost exclusively brushed, brushed-incised, brushed-punctated (where the punctations were either pushed through the brushing, or are in rows above or below brushing marks on the rim or body), or brushed-punctated-appliqued (Table 58) sherds from Bullard Brushed vessels. One brushed-incised sherd with a diagonal incised line cutting across parallel brushing marks may be from a Spradley Brushed-Incised vessel, an Historic Caddo type present in the Neches-Angelina river basins in East Texas.

Table 58. Ancestral Caddo utility ware decorative methods and elements from the Collins site (41TV40).

\begin{tabular}{llll}
\hline Decorative method and elements & Rim & Body & $N$
\end{tabular}

\section{Brushed}

diagonal-opposed brushing marks

diagonal-overlapping brushing marks

opposed brushing marks

overlapping brushing marks

parallel brushing marks

$\begin{array}{lll}- & 8^{*} & 8 \\ 1 & - & 1 \\ - & 8 & 8 \\ - & 3 & 3 \\ - & 26 & 26\end{array}$

\section{Brushed-Incised}

opposed brushed-incised marks and lines parallel brushed-incised marks and lines

parallel brushing marks and diagonal incised line through the brushing

vertical brushing [rim]-broad horizontal incised line

$\begin{array}{lll}- & 1 \\ - & 2 & 2 \\ - & 1 & 1 \\ 1 & - & 1 \\ & & \end{array}$

at rim-body juncture-diagonal and opposed brushing

marks [body] 
Table 58. Ancestral Caddo utility ware decorative methods and elements from the Collins site (41TV40), continued

\begin{tabular}{|c|c|c|c|}
\hline Decorative method and elements & Rim & Body & $\mathrm{N}$ \\
\hline \multicolumn{4}{|l|}{ Brushed-Punctated } \\
\hline diagonal brushed-tool punctated row & - & 1 & 1 \\
\hline $\begin{array}{l}2+\text { horizontal tool punctated rows [rim] and diagonal } \\
\text { brushing [body] }\end{array}$ & 1 & - & 1 \\
\hline $\begin{array}{l}\text { horizontal brushing [rim]-tool punctated row under } \\
\text { lip and above brushing }\end{array}$ & 1 & - & 1 \\
\hline $\begin{array}{l}\text { horizontal brushed with tool punctated row through } \\
\text { the body }\end{array}$ & 2 & 1 & 3 \\
\hline vertical brushing marks-tool punctated row at rim-body & $8 *$ & - & 8 \\
\hline vertical brushed marks above tool punctated row & - & 1 & 1 \\
\hline \multicolumn{4}{|l|}{ Brushed-Punctated-Appliqued } \\
\hline $\begin{array}{l}\text { tool punctated row under lip-vertical brushing-circular } \\
\text { appliqued node }\end{array}$ & 1 & - & 1 \\
\hline \multicolumn{4}{|l|}{ Incised } \\
\hline rectilinear and diagonal incised el. & - & 1 & 1 \\
\hline \multicolumn{4}{|l|}{ Incised-Punctated } \\
\hline parallel incised lines-horizontal tool punctated row & - & 1 & 1 \\
\hline Totals & 15 & 54 & 69 \\
\hline
\end{tabular}

The remainder of the grog or grog-bone-tempered utility ware sherds at the Collins site include only one incised and one incised-punctated body sherd (see Table 58). The incised sherd has a rectilinear incised line creating a zone filled with diagonal incised lines. The other body sherd may be from a Maydelle Incised vessel with a set of parallel incised lines adjacent to a row of horizontal tool punctations.

Perhaps the most intriguing ceramic vessel sherds at the Collins are a number of bone-tempered body $(n=15)$ and rim $(n=1)$ sherds with rectilinear and curvilinear brown painted bands (Figure 76). Such sherds are common in early and late $18^{\text {th }}$ century South Texas and coastal missions such as Mission Espiritu Santo at Goliad (41GD1, Mounger 1959), Mission Refugio (41RF1, Perttula 2002b:Table 9c7), and at the San Antonio missions (see Fox and Ulrich 2008:40 and Figure 4-2); they are particularly common in the central coastal plains missions (Steve Tomka, April 2017 personal communication), and may have been made by Aranama potters. That this mission-era pottery occurs at the Collins site along with a number of Guerrero arrow points (Suhm 1955:Plate 2j-n), and a single Cuney arrow point (Suhm 1955:Plate $2 \mathrm{v}$ ), strongly suggests that there is an $18^{\text {th }}$ century aboriginal occupation at the Collins site. Some of the ancestral Caddo sherds identified in the assemblage may be associated with this component. In combination with Guerrero arrow points at the nearby Smith Rockshelter (see below) and late $17^{\text {th }}$ early $19^{\text {th }}$ century calibrated radiocarbon dates further suggest that there may have been a community of aboriginal peoples periodically using the Onion Creek valley in Historic times. Although there are a number of ethnic/tribal possibilities (e.g., Kenmotsu and Arnn 2012), perhaps they were one of the TransColorado River tribes (Foster 1995:Map 1). 


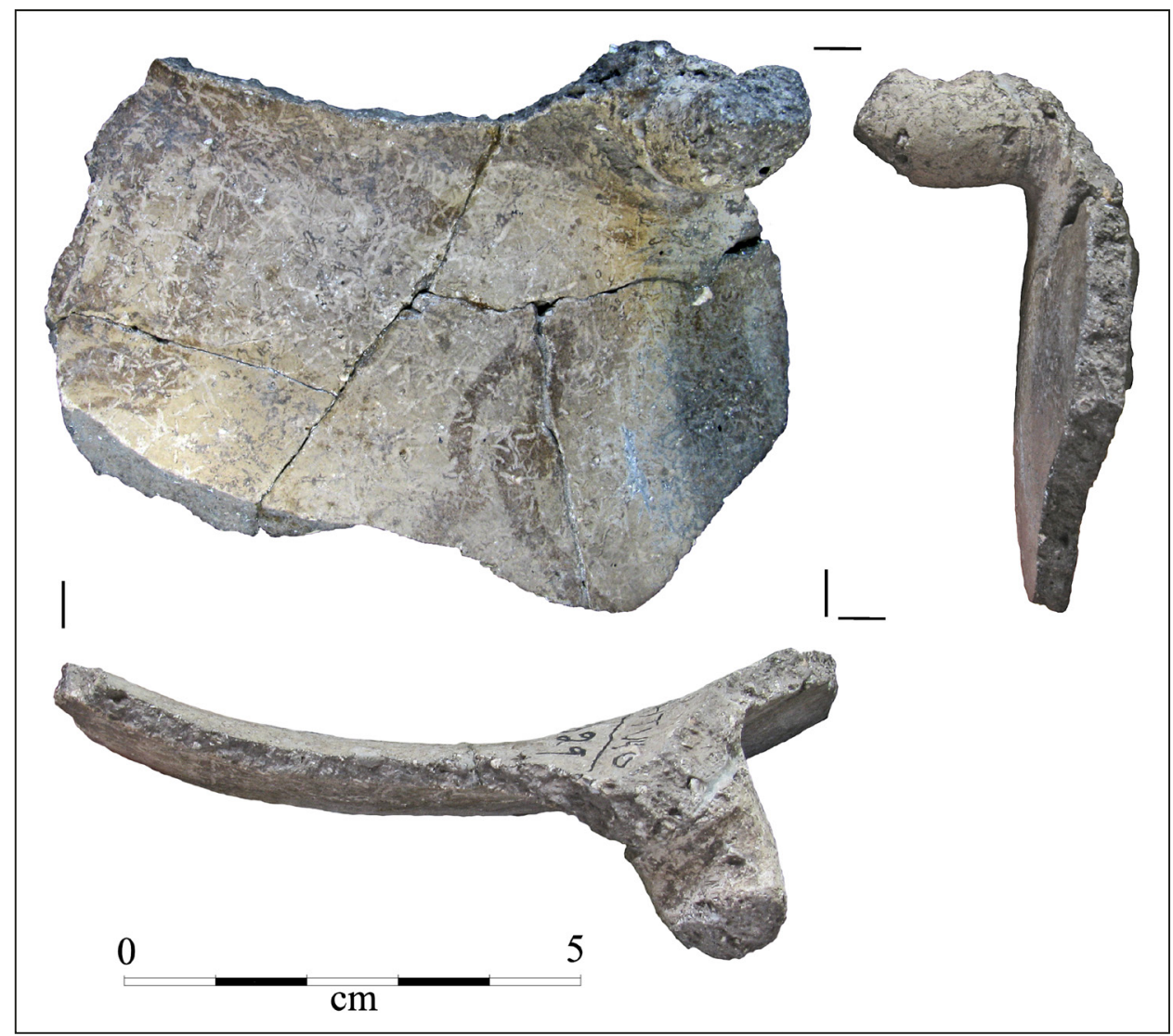

Figure 76. Brown painted rim sherd with brown painted bands and a loop handle from the Collins site (41TV40).

\section{Smith Rockshelter (41TV42)}

Excavations reported by Story $(1956,1957)$ recovered 229 ceramic vessel sherds in a Toyah phase or later early Historic occupation (based on the recovery of several Guerrero style arrow points) archaeological deposit (Occupation XI) from the Smith Rockshelter on Onion Creek near the Colorado River. Three main sherd groupings include 29 sherds from a Leon Plain jar, 27 sherds from a sandy paste (possible Goose Creek Plain, var. unspecified) vessel, though unlikely to be Goose Creek Plain given the much earlier age of sandy paste pottery in the region compared to the age of Occupation/Zone XI), and 159 sherds from a plain and relatively thick-walled (6-9 $\mathrm{mm}$ in thickness) shell-tempered and sandy paste vessel (a bowl or a jar, perhaps related to Nocona Plain) (Story 1957:Plate 9p-r).

Three uncorrected radiocarbon dates from 0-6 inches bs in Zone XI at the Smith Rockshelter range from $240 \pm 70$ years B.P. to $200 \pm 70$ years B.P. (Valastro and Davis 1970:271), with a mean uncorrected age range of $220 \pm 70$ years B.P., or A.D. 1660-1800. Shafer and Hester (2014:19) note that "these are among the youngest dates thus far obtained on a Toyah assemblage," and these dates also indicate that the ancestral Caddo sherds from Zone XI date to Historic Caddo period times. Dates of A.D. 1739-1820 and A.D. 1626-1813 were recalculated by Johnson (1994:258).

Among the 14 miscellaneous sherds in the collection is an ancestral Caddo vessel rim sherd with incised lines, probably from a Maydelle Incised vessel, and six plain body sherds from an ancestral Caddo grog-tempered vessel with exterior burnishing (INAA, UT00129). Two bone-tempered ceramic strap handles are also in the ceramic collection from the Smith Rockshelter. 


\section{Sneed (41TV104)}

The only ancestral Caddo ceramic vessel sherd in the TARL collections from 41TV104 is a plain grog-tempered body sherd (INAA, UT00139).

\section{Hillcrest Bluff (41TV142)}

This site has Toyah phase Leon Plain pottery sherds as well as a single plain grog-bone-tempered Caddo body sherd in the TARL collections that is $7.0 \mathrm{~mm}$ in thickness (INAA, UT00033).

\section{Toyah Bluff (41TV441)}

Investigations at the Toyah Bluff site on an Onion Creek terrace in the Colorado River basin recovered 48 ceramic vessel sherds that Karbula (2003:75) divided into three different groups. Groups 1 and 2 include sherds from bone-tempered Leon Plain vessels, although two of the sherds placed in Group 1 are plain grog-bone-tempered body sherds, and likely to not belong in this group. Ceramic Group 3 has grog $(n=3)$, grog-bone $(n=4)$, and grog/sandy paste sherds $(n=3)$, and may actually represent parts of several different ancestral Caddo vessels. The one decorated sherd in Ceramic Group 3 is a grog-bonetempered body sherd with parallel brushing marks, likely from an East Texas Bullard Brushed vessel.

\section{Uvalde County}

\section{Kincaid Rockshelter (41UV2)}

In addition to Toyah phase bone-tempered sherds in the ceramic assemblage, there is a grog-tempered rim sherd (INAA, UT00093) from an ancestral Caddo jar, probably Bullard Brushed, with horizontal brushing marks. The jar has a $23.0 \mathrm{~cm}$ orifice diameter.

\section{Williamson County}

\section{Cedar Park Mound (41WM8)}

In addition to sherds from Leon Plain vessels, there are grogtempered sherds from three different ancestral Caddo vessels at the Cedar Park Mound site. One is a plain grog-tempered body sherd, another seven are from Vessel 2, a grog-tempered engraved vessel, and a third is from a grog-tempered body sherd with parallel brushing marks (INAA, UT00136). The vessel sherds from Vessel 2 are from a post-A.D. 1680 Patton Engraved vessel that has horizontal and diagonal engraved lines with triangular excised tick marks (Figure 77). Such vessels were made after A.D. 1680 by Hasinai Caddo potters of the Allen phase, who lived in the NechesAngelina River basins in East Texas.

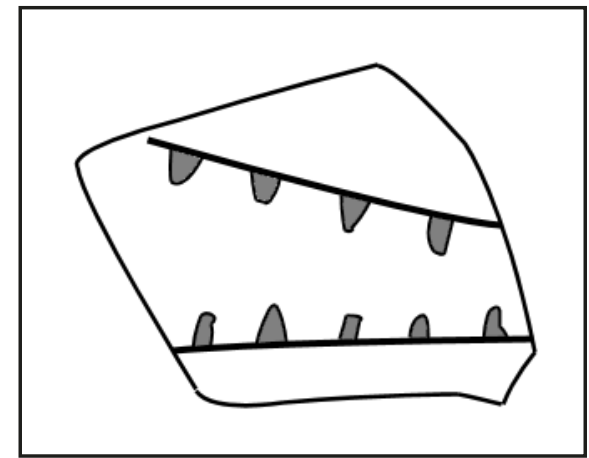

Figure 77. Decorative elements on a Patton Engraved body sherd from the Cedar Park Mound site. 


\section{Cluck Spring (41WM24)}

Fragments of a single grog-tempered Holly Fine Engraved vessel, likely a deep bowl (see Suhm and Jelks 1962:Plates 39f, h and 40f) was recovered by J. E. Pearce in 1929 at the Cluck Spring site. The vessel has a series of concentric engraved semi-circles, diagonal engraved lines, and small excised semicircles on the rim and body of the vessel (Figure 78). A white kaolin clay pigment has been rubbed into the engraved lines by the Caddo potter. Holly Fine Engraved vessels were generally manufactured by the Caddo from ca. A.D. 900-1200.

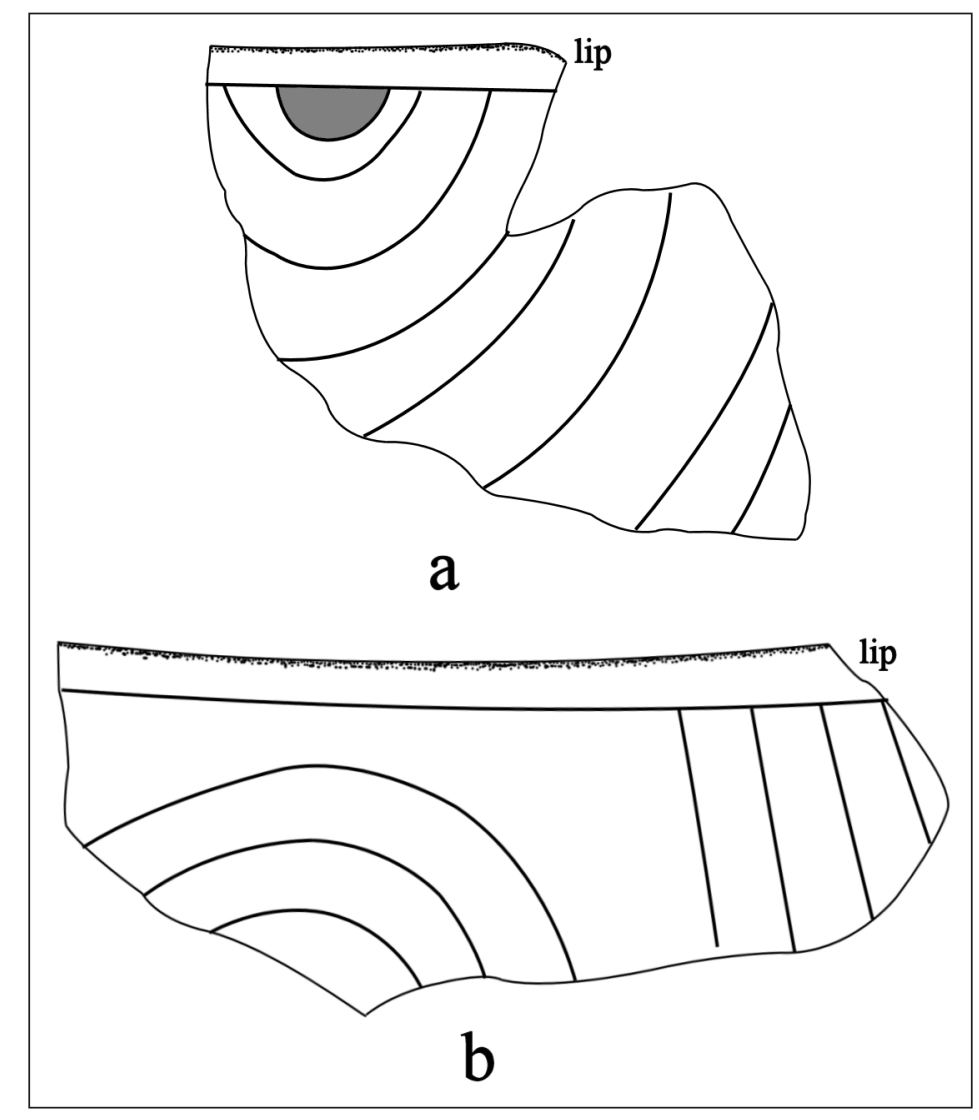

Figure 78. Decorative elements on Holly Fine Engraved vessel sherds from the Cluck Spring site, Williamson County, Texas.

\section{Barker (41WM71)}

This site has both Toyah phase bone-tempered Leon Plain sherds $(n=2)$ as well as ancestral Caddo ceramic sherds in the TARL collections; Sorrow (1970:17) indicated that there were originally 34 Leon Plain bone-tempered sherds from three vessels (Vessels 3-5). The Caddo ceramic sherds include a plain grog-bone-tempered body sherd and bone-tempered body sherds with parallel brushed-incised marks and lines (Figure 79a-b); the brushed sherds are from Vessel 2 (Sorrow 1970:15). There also is a very distinctive everted rim jar with an incised decoration on the rim and upper vessel body, as well as two small loop handles (Figure 79c-f); Sorrow (1970:15) labeled this as Vessel 1, and he noted that there were 29 sherds in the collections from this vessel at the Barker site. 


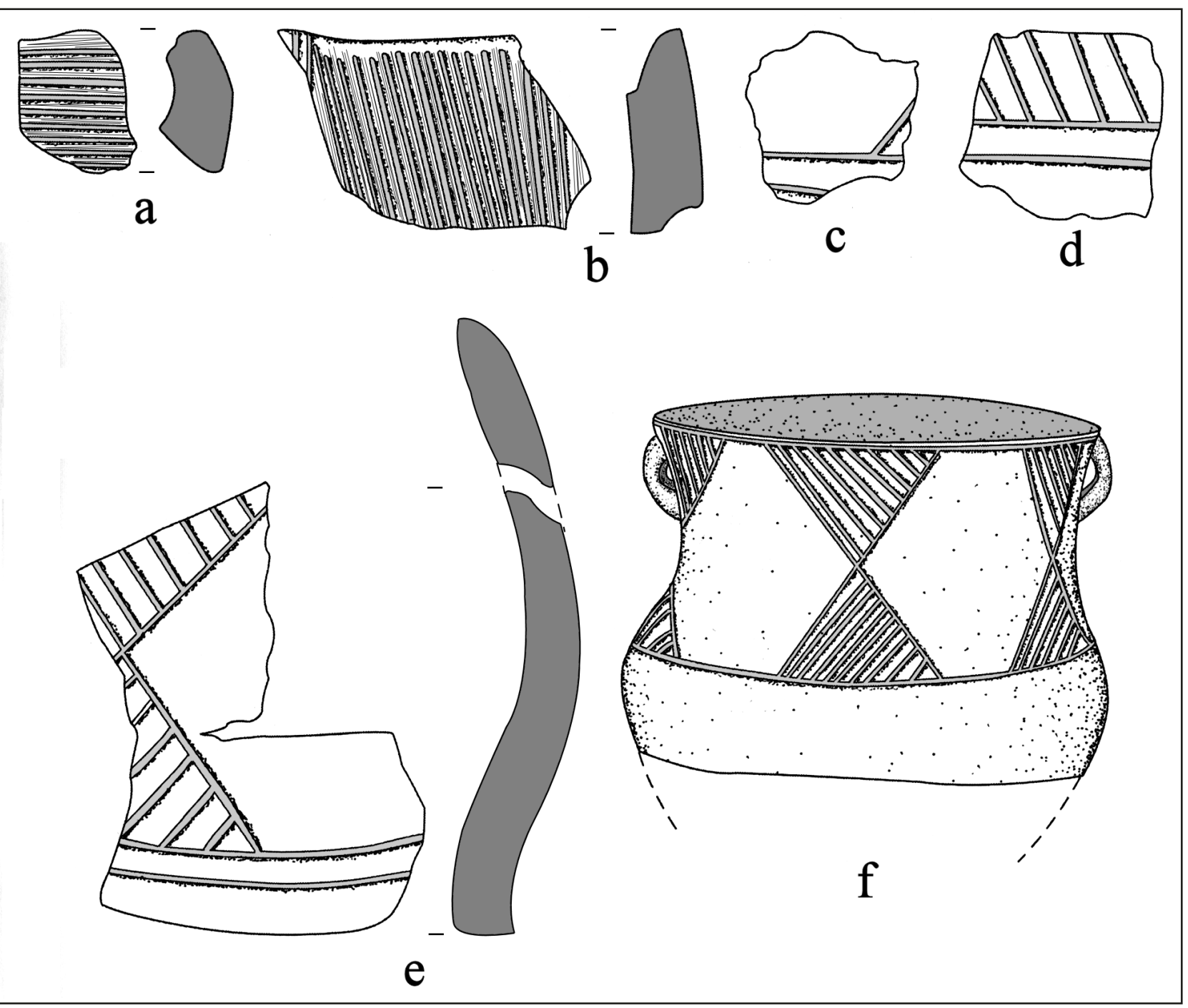

Figure 79. Vessel 1 from the Barker site (from Sorrow 1970:Figure 5) and brushed-incised body sherds.

The vessel is tempered with bone, grog, and angular quartzite fragments. The decorative motif includes opposed sets of diagonally incised triangles pendant from the rim and upper body juncture (see Figure 79e-f). There are also two horizontal incised lines that circle the vessel at the upper body juncture and below the lower set of diagonally incised triangles. The use of opposed and pendant incised and engraved triangles in zones around the rim is common in East Texas Caddo ceramics, typically ceramics made after ca. A.D. 1400 in Frankston phase contexts (see Perttula 2011).

\section{$41 W M 118$}

There are four ancestral Caddo ceramic vessel sherds of unknown age in the TARL collection from 41WM118, although the one probable Holly Fine Engraved sherd suggests they date before ca. A.D. 1200. Three are plain grog-tempered body sherds (INAA, UT00040) that have been burnished on both interior and exterior surfaces, suggesting they are from the undecorated portions of a carinated bowl. The fourth sherd is a grog-tempered body sherd (INAA, UT00046) from a carinated bowl with diagonal engraved lines, probably from a Holly Fine Engraved vessel. 


\section{Bryan Fox (41WM124)}

A single plain grog-tempered body sherd in the TARL collections is from a ceramic vessel manufactured by an ancestral Caddo potter sometime after ca. A.D. 800, and recovered in Area A at this site. It came from N801-W804, level 7. Another sherd of likely Caddo manufacture is a plain body sherd with grog temper and a sandy paste. There is also a post-A.D. 1300 grog-tempered plain bowl sherd from an ancestral Caddo elbow pipe.

\section{Hoxie Bridge (41WM130)}

Investigations by Bond $(1978: 137,139)$ at the Hoxie Bridge site recovered one bone-tempered Caddo pottery sherd with incised-punctated decorative elements along with plain sandy paste pottery $(n=10)$ and four sherds of Leon Plain. The Caddo sherd had curvilinear incised zones filled with rows of small tool punctations that paralleled the incised lines, decorative elements consistent with Early Caddo period utility wares such as Crockett Curvilinear Incised or Pennington Punctated-Incised.

The plain sandy paste sherds in the assemblage may be Goose Creek Plain, var. unspecified sherds from East Texas or upper Texas Coast Woodland period peoples (see Story 1990a). If they had been made by Woodland period potters ancestral to the Caddo, the sandy paste sherds would date from ca. 500 B.C. to A.D. 800. There are a few plain sandy paste sherds from other Central Texas sites-including sites in Bell, Hamilton, Hill, McLennan, and Williamson - indicating that Woodland period ceramic ware were obtained for use by Central Texas aboriginal inhabitants. Sandy paste sherds from two sites in the Colorado River basin in nearby Bastrop County have been considered to be of Late Prehistoric age (see Nickels et al. 2010:370), but no temporal evidence was offered from either site to support this assertion, other than the assumption that sandy paste plain sherds date to within the Late Prehistoric period.

\section{Loeve (41WM133)}

One of the sherds in the TARL collections from the Loeve site is a sandy paste Goose Creek Plain, var. unspecified body sherd (INAA, UT00045); as previously discussed, his sherd was made in Woodland period times (ca. 500 B.C.-A.D. 800) in the southern parts of East Texas and along the Texas Gulf Coast (see Story 1990a). The other seven sherds in the collection are ancestral Caddo wares that include plain grog-bone-tempered $(n=2$, INAA, UT00044) and plain grog-tempered $(n=1)$ sherds, and four decorated bone or grog-tempered sherds. One grog-tempered rim sherd is from a carinated bowl and has diagonal and cross-hatched engraved lines (Figure 80). Another sherd is a bone-tempered body sherd with parallel incised lines, while two other sherds (tempered either with grog or bone) have cross-hatched incised lines (INAA, UT00042), and may be from Canton Incised or Maydelle Incised vessels.

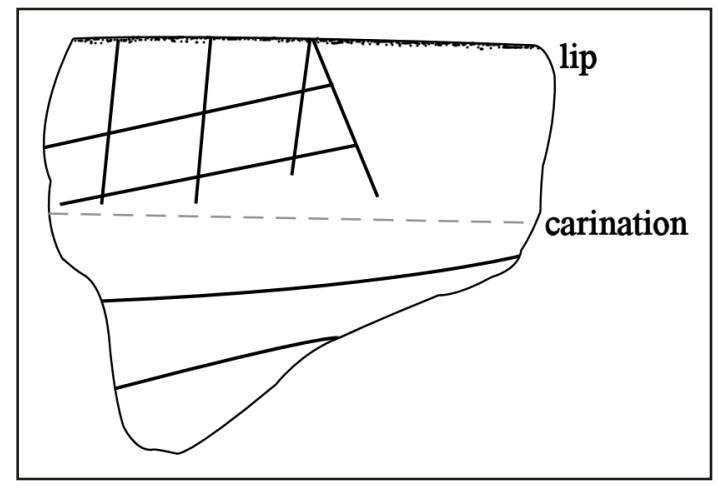

Figure 80. Decorative elements on engraved carinated bowl rim sherd from the Loeve site (41WM133). 


\section{WM163}

Excavations in Area A (N1001-W1004, level 4) at 41WM163 recovered five ancestral Caddo sherds. This includes a plain grog-bone-tempered rim sherd, three plain grog-bone-tempered body sherds, and one plain grog-tempered body sherd. The specific age of these sherds is not known, and it can only be estimated that they date sometime after ca. A.D. 800, the beginning of the Formative Caddo period and the beginning of the manufacture of ancestral Caddo tempered ceramic wares.

\section{Loeve-Fox (41WM230)}

There is a single plain grog-tempered and sandy paste body sherd from the Loeve-Fox site (Prewitt 1974:108 and Figure 23a), as well as a grog-tempered pipe bowl sherd (Prewitt 1974:108-109 and Figure 23b-c), not pieces of burned clay, likely from a long-stemmed Red River style pipe (see Hoffman 1967) given its $21.0 \mathrm{~mm}$ orifice diameter. These pipes were made from ca. A.D. 800-1400 in the Caddo area. The bowl is $7.1 \mathrm{~mm}$ thick.

\section{Bigon-Kubala Site (41WM258)}

The TARL ceramic collections from the Bigon-Kubala site primarily consist of bone-tempered Leon Plain body and base sherds $(n=159)$, but there are a number of grog and grog-bone-tempered Caddo ceramic sherds in XU2 excavations. These consist of three decorated sherds and 35 plain rim and body sherds. They are tempered with grog $(n=24)$ and grog-bone $(n=14)$. The decorated sherds include a body sherd with a single straight incised line, another bod sherd with opposed incised lines, and a grog-bonetempered body sherd with a single tool punctate.

There are red-slipped sherds reported from the Bigon-Kubala site on the San Gabriel River (Hays 1982:8-230) that may be from Caddo ceramic vessels. The use of a red slip is a common feature in both Middle and Late Caddo periods in sites on the Red River and the Sabine River in East Texas (see Perttula 2015a).

\section{WM267}

An engraved Caddo sherd with an unknown decorative motif has been found at 41WM267 at Granger Lake (Carey Weber, 2016 personal communication).

\section{Rowe Valley (41WM437)}

The Texas Archeological Society held Field Schools at the Rowe Valley site on the San Gabriel River in the Brazos River basin in 1982-1984 (Prewitt 1982, 1983a, 1983b, 1984). Prewitt (2012:200; see also Rush et al. 2015:113) notes that at least eight different Leon Plain bone-tempered pottery vessels have been recovered in excavations at the Rowe Valley site in the ca. A.D. 1650-1700 occupational level at the site (i.e., upper Toyah phase and Younger Age group), along with ancestral Caddo ceramic vessel sherds. These ceramic vessel sherds occur in four different clusters in the upper Toyah phase component (Prewitt 2012:Figure 9.4). Recent calibration of six related dates from the "Younger Age Group" range, however, when combined in OxCal, from A.D. 1645-1664 (Rush et al. 2015:125 and Figure 10).

I recently had the opportunity to document and analyze the ceramic vessel sherds from the Rowe Valley site. I first identified the technological and/or stylistic character of each of the vessel sections, focusing on the temper, firing conditions, presence of organic residues, surface treatment, rim and lip 
profile, and vessel wall thickness, along with the decorative methods (i.e., incised, brushed, etc.) and decorative elements present on certain vessel sections. Here I also discuss the cultural affiliations of the different vessels from the Rowe Valley site relying on technological and stylistic attributes and the results of the instrumental neutron activation analysis of sherds from seven of the vessel sections (see Creel et al. 2013; Perttula et al. 2003).

\section{Vessel 1}

Vessel 1 at the Rowe Valley site is a partially reconstructed brushed-punctated-appliqued jar (Figures 81 and 82a-c) of the Bullard Brushed type tempered with grog and small amounts of quartz sand. The jar includes 102 sherds that are mainly conjoined into nine sherds that are part of the rim (Figure 82a), the rim-body (Figure 82b), the lower rim-body (Figure 82c), and the vessel body sections. The rim ranges between 6.3-7.9 $\mathrm{mm}$ in thickness, while the body walls range from 6.7-7.6 $\mathrm{mm}$ in thickness. The rim has a direct profile and a rounded lip, with a $9.5 \mathrm{~cm}$ orifice diameter. The rim height is $6.2 \mathrm{~cm}$, and the height from the lower rim to the lower body is $13.3 \mathrm{~cm}$ in height. Its estimated volume is 1.1 liters.

The vessel rim has horizontal brushing marks along with a row of tool punctations below the lip and at the rim-body juncture (see Figures 81 and 82a). Also on the rim are sets (probably four sets) of two narrow vertical appliqued ridges that are $10 \mathrm{~mm}$ apart; the area between the appliqued ridges has no brushing marks. The vessel body has horizontal and opposed brushing marks (see Figures 81 and $82 \mathrm{~b}-\mathrm{c}$ ) that likely extend to the vessel base.

This vessel has been smoothed on the interior surface, and there are fire clouds on both interior and exterior surfaces; organic residue is present on the interior vessel surface. Core profiles indicate that Vessel 1 was fired in a reducing environment and cooled in the open air (see Teltser 1993:Figure 2f).

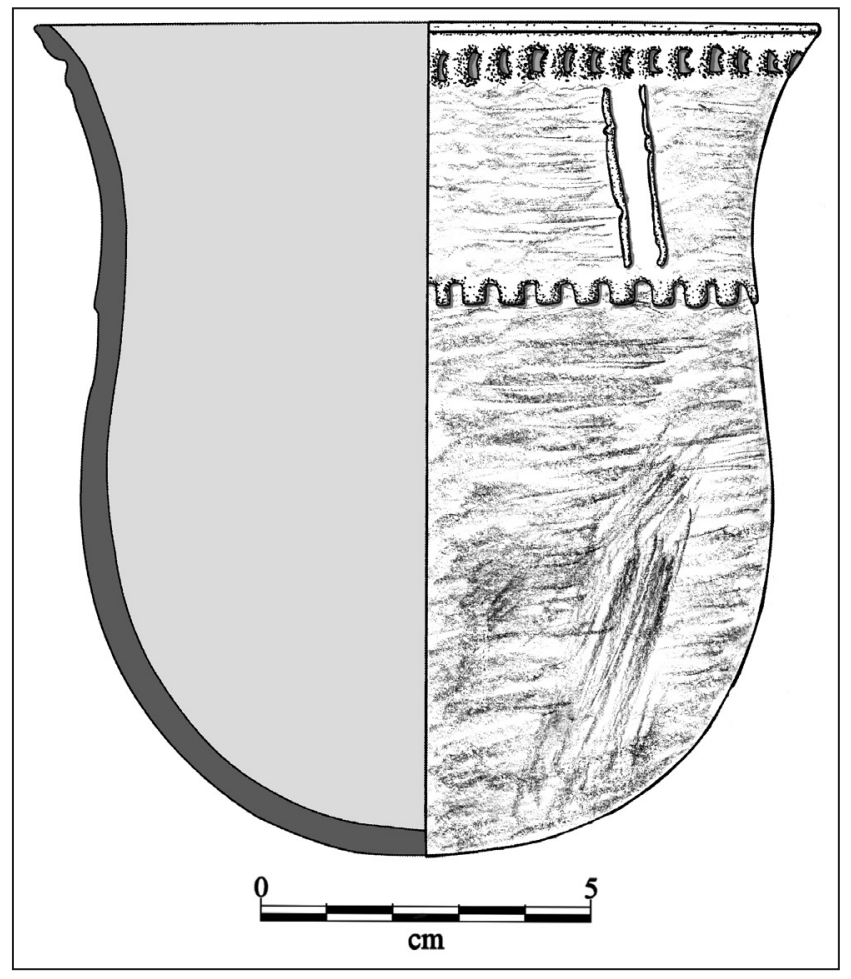

Figure 81. Reconstructed form for Vessel 1 at the Rowe Valley site (41WM437). after Perttula et al. (2003:Figure 5). 

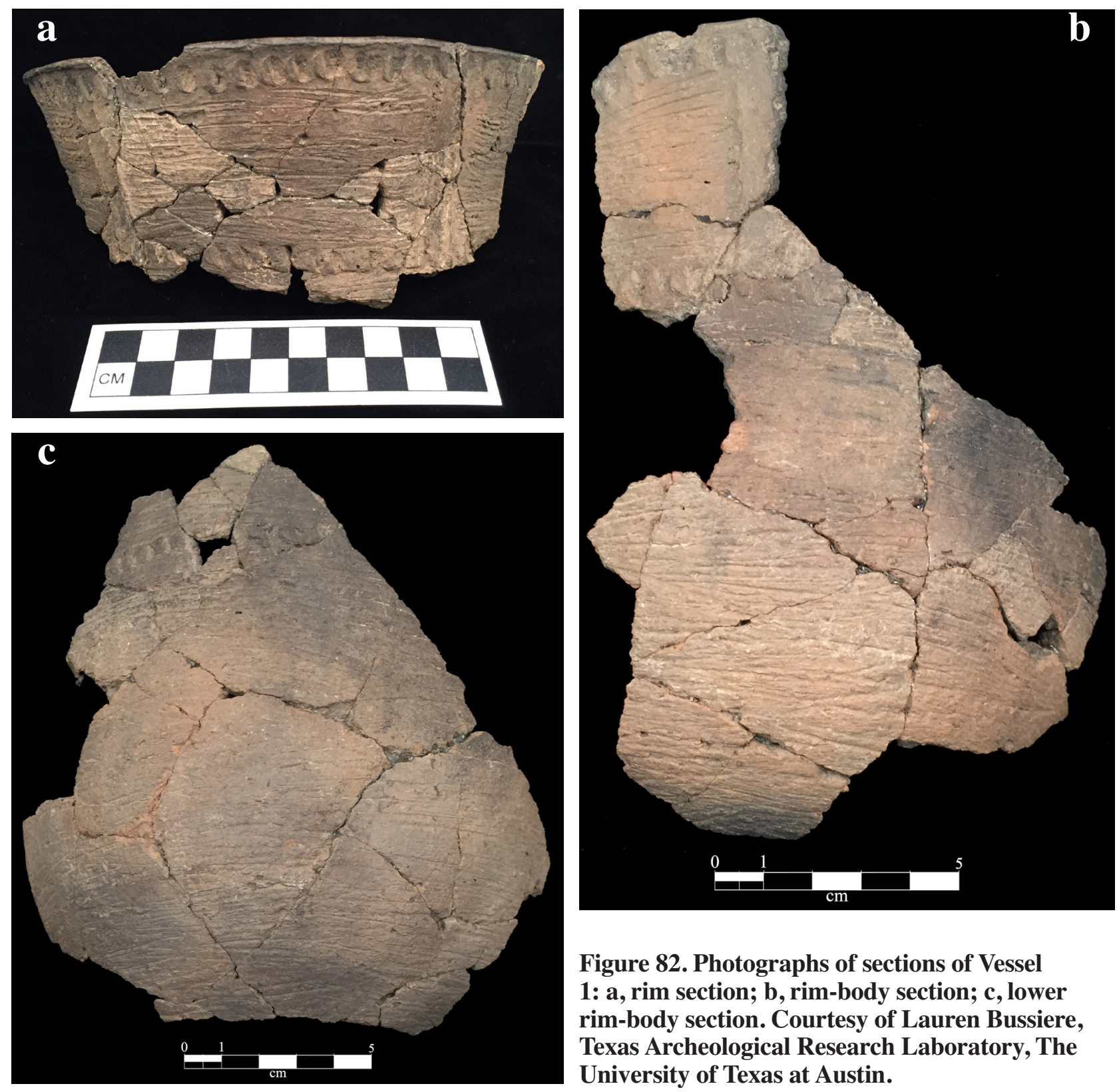

Figure 82. Photographs of sections of Vessel 1: a, rim section; b, rim-body section; c, lower rim-body section. Courtesy of Lauren Bussiere, Texas Archeological Research Laboratory, The University of Texas at Austin.

One sherd from the site (TKP155) was submitted for instrumental neutron activation analysis (INAA) and petrographic analysis (see Perttula et al. 2003) as part of an initial study of Caddo ceramics found on Central Texas sites. Its chemical composition generally matches ancestral Caddo sherds from both north and south of the Sabine River (see Perttula et al. 2003:Table 9). Creel et al. (2013:65) comment that the sherd from this vessel "is more similar chemically to Caddo pottery and it is likely that the sample was actually from a Caddo brushed vessel."

\section{Vessel 2}

Vessel 2 is a Patton Engraved bowl (Figure 83) tempered with grog. Patton Engraved vessels were manufactured after ca. A.D. 1680 by Caddo potters living in Hasinai Caddo communities in the Neches-Angelina river basins. Patton Engraved is the primary engraved fine ware in historic Allen phase components in the region (Perttula 2011, 2013). 


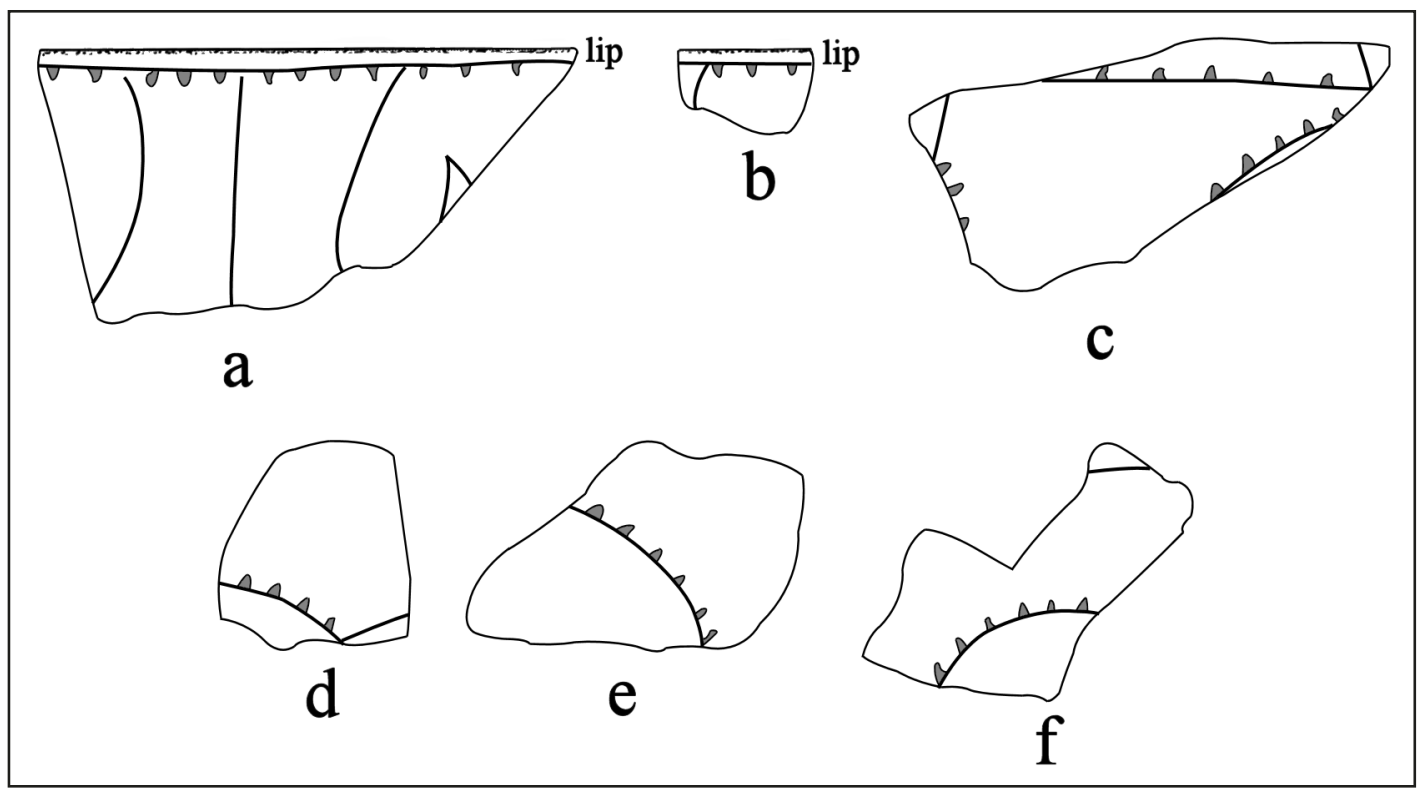

Figure 83. Decorative elements on Patton Engraved vessel from the Rowe Valley site (Vessel 2, 41WM437): a-b, rim sherds; c-f, body sherds.

This vessel is represented by 12 rim and body sherds; the rim is direct in profile, with a rounded and slightly exterior folded lip; the orifice diameter is estimated at $7.0 \mathrm{~cm}$. The rim sherds range from 4.9$5.1 \mathrm{~mm}$ in thickness, and the body sherds range from 4.7-6.3 $\mathrm{mm}$. Both interior and exterior surfaces are burnished, which is a common surface treatment on ancestral Caddo fine ware vessels, and the vessel was fired in a reducing environment and cooled in the open air (see Teltser 1993:Figure 2f).

The rim has upper and lower horizontal engraved lines with downward or upward-pointing excised tick marks, as well as vertical to curvilinear lines connecting the upper and lower horizontal engraved lines (see Figure 83a-b). The use of the vertical dividers on the rim panel suggests that Vessel 2 is a Patton Engraved, var. Freeman vessel (Perttula 2011:Figure 6-66c), perhaps the earliest variety of Patton Engraved. The vessel body has curvilinear engraved lines with excised tick marks (see Figure 83c-f), also a feature of Patton Engraved, var. Freeman vessels.

One sherd from this vessel (TKP156) was submitted for INAA and petrographic analysis. The sherd has been sourced to the Neches-Angelina river basin in East Texas, indicating it was manufactured by an Allen phase potter in the Hasinai Caddo area of East Texas (Creel et al. 2013:65; Perttula et al. 2003:Table 9).

\section{Vessel 3}

This vessel is a plain and bone-tempered jar with riveted handles (Figure 84), possibly a Goliad Plain jar made in $18^{\text {th }}$ century contexts in mission sites in South Texas. Riveted handles are relatively common in ceramic assemblages with Goliad Plain (Perttula et al. 2003:19). The vessel includes one rim sherd (5.2 $\mathrm{mm}$ thick, and with a direct profile and rounded lip) with an $8.0 \mathrm{~cm}$ orifice diameter, two rim sherds with riveted handles, 13 body sherds (5.1-5.6 mm thick), and two handle sherds. The interior and exterior surfaces of the vessel have patches of smoothed to burnished areas. The handles are $10.7 \mathrm{~mm}$ in width, $5.2 \mathrm{~mm}$ in thickness, and are at least $23.0 \mathrm{~mm}$ in length. The vessel has been fired in a reducing environment and cooled in the open air (see Teltser 1993:Figure 2f). 


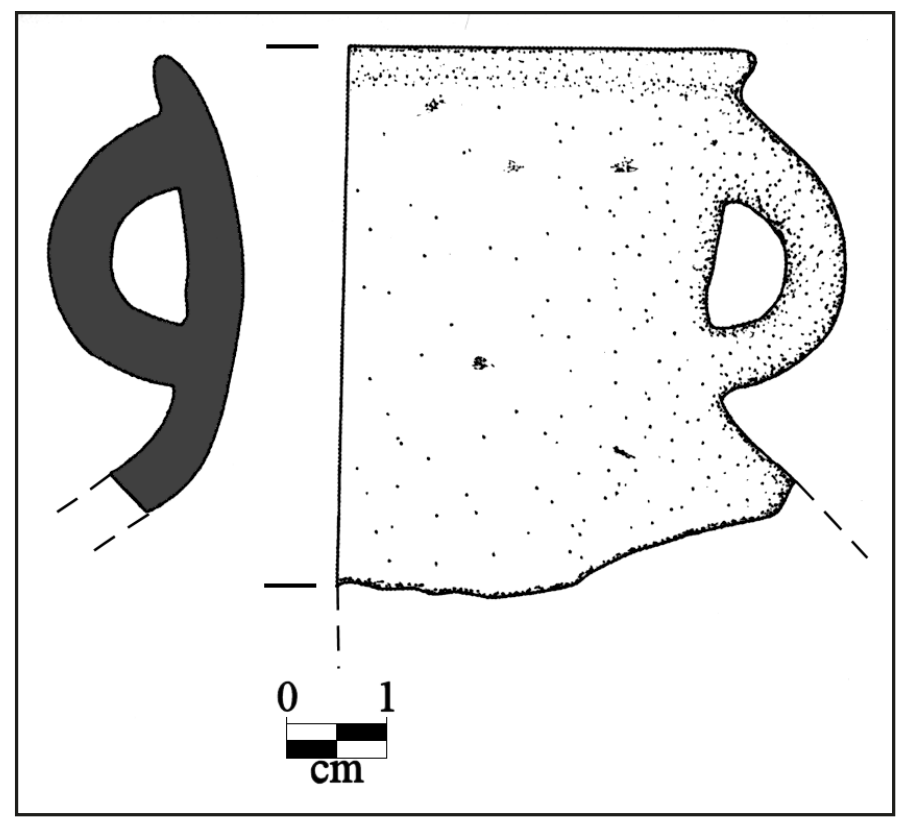

\section{Figure 84. Reconstructed vessel form for Vessel 3 at the Rowe Valley site (41WM437), after Perttula et al. (2003:Figure 6).}

One sherd from Vessel 3 (TKP157) was submitted for INAA and petrographic analysis. These indicate that the vessel was not made locally in Central Texas (Perttula et al. 2003:Table 9). Most of the Goliad Plain samples in the Central Texas INAA database have been included in Group 10, from sites along the Balcones Escarpment and the coastal plain (Creel et al. 2013:Figures 20-23). The Goliad Plain sherd from the Rowe Valley site has been assigned to Group 10C (Creel et al. 2013:61 and Figure 23).

\section{Vessel 4}

Vessel 4 is represented by one rim sherd and eight body sherds of a plain bone-tempered vessel of the Leon Plain type. The rim and body sherds are $6.2 \mathrm{~mm}$ in thickness, with interior and exterior smoothed surfaces. The rim has a direct profile and a flat lip. The vessel was fired and cooled in a reducing environment (see Teltser 1993:Figure 2b).

A sherd from this vessel (UT379) was included in the Creel et al. (2013) INAA study of Central Texas ceramics. Compositional clusters of Leon Plain vessels fall in the Edwards Plateau of west central Texas (Cluster A) as well as along the Balcones Escarpment (Cluster B). This sherd has been assigned to Group 10 of Cluster B (Creel et al. 2013:Table 5), indicating a local manufacture of Vessel 4.

\section{Vessel 5}

Vessel 5 is a plain bone-tempered vessel with an exterior burnished surface and an interior smoothed surface, likely a Leon Plain jar. The vessel section has six rim sherds and 33 body sherds, most that could be conjoined. The rim has a direct profile with a rounded, interior beveled lip, and it has a $10.0 \mathrm{~cm}$ orifice diameter. The rim sherds range from 6.3-6.4 mm in thickness, and the body sherds range from 6.0-6.7 $\mathrm{mm}$ thick. The vessel is plain and was fired in a reducing environment and cooled in the open air (see Teltser 1993:Figure 2f, h). 
One sherd from Vessel 5 (TKP158) was submitted for INAA and petrographic analysis. They indicate that this vessel was manufactured from Central Texas clays, probably obtained near the Rowe Valley site.

\section{Vessel 6}

Vessel 6 is represented by five body sherds, four of which conjoin. They are from a plain bonetempered vessel, of the Leon Plain type, that was fired in a reducing environment and cooled in the open air (see Teltser 1993:Figure 2g). The interior and exterior surfaces of the sherds have been smoothed, and body wall thickness ranges from 6.0-8.0 mm. A sherd from this vessel (UT386) was submitted for INAA, and determined to have been made from Central Texas clays, likely from a clay source not far distant from the Rowe Valley site.

Three plain body sherds included in the Vessel 6 bag appear to be from a separate vessel. The vessel sherds are bone-tempered and have a sandy paste, and there is an organic residue on the interior surface of each sherd. The sherds range in thickness from 5.4-6.3 $\mathrm{mm}$, and they have been smoothed on both interior and exterior surfaces. The sherds are from a vessel that was fired and cooled in a reducing or low oxygen environment (see Teltser 1993:Figure 2b).

\section{Vessel 7}

The three body sherds from Vessel 7, a Leon Plain vessel, two of which conjoin, are plain and bonetempered. The sherds are $5.1 \mathrm{~mm}$ thick, and have been smoothed on their exterior surfaces. The vessel was fired in a reducing environment and cooled in the open air (Teltser 1993:Figure 2f).

\section{Vessel 8}

There is one bone-tempered plain body sherd from Vessel 8, likely from a Leon Plain vessel. The body sherd is only $3.3 \mathrm{~mm}$ in thickness, and there is no surface treatment. The sherd is from a vessel fired and cooled in a reducing environment (Teltser 1993:Figure 2b).

\section{Vessel 9}

Vessel 9 includes 13 body sherds from a bone-tempered vessel with parallel to opposed brushing marks; the sherds have been smoothed on the interior vessel surface. The body sherds range from 5.1-7.1 $\mathrm{mm}$ in thickness. This vessel was fired in a reducing environment and cooled in the open air (see Teltser 1993:Figure 2h).

A sherd (UT 380) from Vessel 9 was included in the Creel et al. (2013:65) INAA study of Central Texas ceramics; it was considered to be an untyped brushed vessel. The INAA study indicates that this vessel at the Rowe Valley site was made by potters using Group 10 clays. According to Creel et al. (2013:60 and Figure 20), sherds from vessels made with these clays are "concentrated in sites along the Balcones Escarpment from the San Antonio area northeast to the greater Austin area but with members scattered all through Central Texas and on the Gulf Coastal Plain."

\section{Vessel 10}

There is one body sherd in the collection from this vessel at the Rowe Valley site. The body sherd, $4.9 \mathrm{~mm}$ thick, is from a grog-tempered vessel that was fired and cooled in a reducing environment (see Teltser 1993:Figure 2b); it has been burnished on the exterior surface. The body sherd has parallel engraved lines, and one of the lines has a possible excised tick mark, suggesting it may be from an ancestral Caddo Patton Engraved vessel (see Vessel 2). 


\section{Vessel 11}

Vessel 11 is represented by one plain lower rim-body sherd from a bone-hematite-tempered vessel, likely Leon Plain. The body sherd is only $4.3 \mathrm{~mm}$ in thickness, and the exterior surface has been smoothed and the interior surface has been burnished. The vessel was fired in a reducing environment and cooled in the open air (Teltser 1993:Figure 2f).

In summary, analysis of the assemblage of ceramic vessel sherds from 11 separate vessel sections recovered from the $17^{\text {th }}$ century Toyah component at the Rowe Valley site (41WM437) during the 1982-1984 Texas Archeological Society Field Schools, indicates that the vessels were made in several production locales in East Texas, Central Texas, and southern Texas.

The East Texas vessel sections include Patton Engraved vessels (Vessel 2 and Vessel 10) and a Bullard Brushed jar (Vessel 1). These three vessels are grog-tempered. Prewitt (2012:200) suggests that the Caddo vessels "are both generally associated with southern Caddo groups in the vicinity of Nacogdoches." In fact, however, Patton Engraved and Bullard Brushed vessels were made by Caddo potters throughout much of the Neches-Angelina river basins in East Texas, particularly in the upper Neches River basin (see Marceaux 2011). Patton Engraved vessels are generally considered to date from after ca. A.D. 1650 in the Caddo area, or even later, beginning about A.D. 1680 and the start of the Historic Caddo period (Perttula 2013). Vessel 2 is from a Patton Engraved, var. Freeman vessel, the earliest Patton Engraved variety made in East Texas (Perttula 2011).

Vessels from the Rowe Valley site made of Central Texas clays are comprised of sherds from six bone-tempered Leon Plain vessels (Vessels 4-8 and Vessel 11). The INAA of these sherds indicate that they are compositionally similar to Group 10 clays (Creel et al. 2013:Figure 20). Vessel 9, a bonetempered brushed jar, is also considered by Creel et al. (2013) to have been manufactured with Central Texas clays, but bone-tempered brushed jars are also common in post-A.D. 1400 contexts in the NechesAngelina river basin and the Sabine River basin (Perttula 2015a:Figure 11).

The last vessel in the assemblage is a bone-tempered Goliad Plain jar (Vessel 3) with riveted handles. This vessel was likely made of coastal plain clays and is not local to the Rowe Valley site.

\section{$41 W M 763$}

Found at 41WM763 is a single ancestral Caddo ceramic sherd with one or more rows of fingernail punctations (Figure 85). The sherd is from a utility ware jar

\section{Unrecorded Site in Williamson County, Darrell Crain Sherd}

Darrell Crain found an engraved Caddo sherd at an unrecorded archaeological site near the San Gabriel River, a few miles east of Georgetown, Texas. Also found there was a Gahagan style biface made from Edwards chert (John Haberer, February 2017 personal communication). The sherd is from a grog-bone-tempered Early Caddo period Holly Fine Engraved bottle (Figure 86) with a carinated body (cf. Suhm and Jelks 1962:Plate 40e). The engraved design consists of a concentric arc or scroll band of engraved lines below a small circle element; there is no clay pigment rubbed in the engraved lines. The bottle had been fired in a reducing environment and cooled in the open air, burnished on its exterior surface, and was $8.1 \mathrm{~mm}$ thick. 


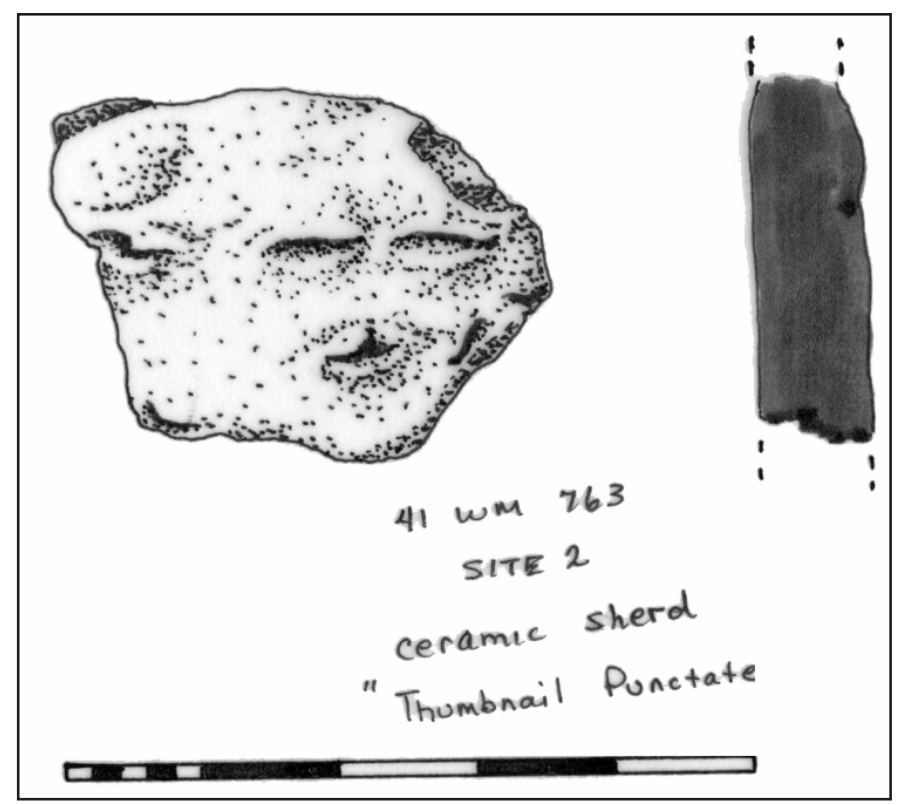

Figure 85. Fingernail punctated sherd from 41 WM763.

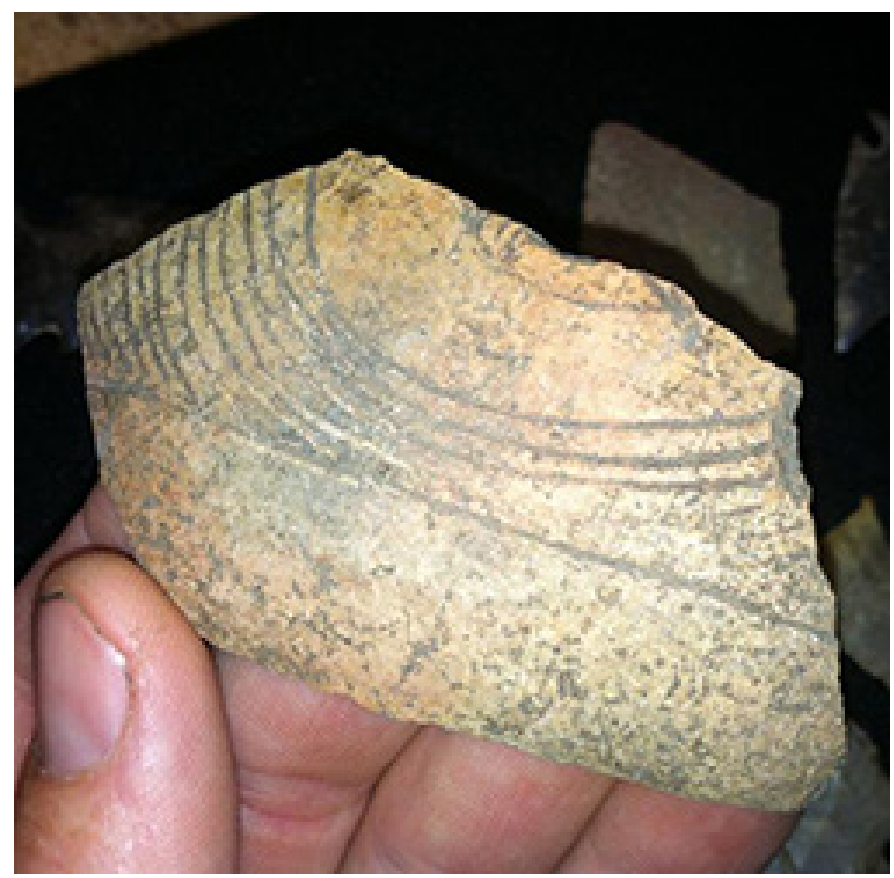

Figure 86. Holly Fine Engraved bottle sherd from a site in Williamson County, Texas, found by Darrell Crain. 


\section{Summary and Synthesis}

Through a combination of means, including examination of collections in curation facilities, information provided by avocational archaeologists, and the review of published literature, ancestral Caddo ceramics have been identified over a wide area of Central Texas as well as in parts of South Texas. This report discusses the ancestral Caddo ceramics from 163 archaeological sites in 34 counties (see Figure 2). The highest proportion of Central Texas sites with Caddo ceramics are in McLennan, Hill, Coryell, and Williamson counties in Blackland Prairie and eastern Edwards Plateau natural regions, due west from ancestral Caddo settlements in the southern part of the East Texas Pineywoods. Other such sites are in the southern Edwards Plateau, the Llano Uplift, and the Rolling Plains, as well as the South Texas Brush Country (i.e., a site in Dimmit County).

Twelve sites ( 7.4 percent of the overall regional sample, see Table 1) in Central Texas have small amounts of plain sandy paste Goose Creek Plain, var. unspecified pottery made and used by Mossy Grove culture Woodland period peoples between ca. 500 B.C.-A.D. 800 (see Story 1990a; Ellis 2013). These sites are concentrated in the Brazos River basin in Hill, McLennan, and Williamson counties in the Blackland Prairie (Figure 87). The presence of this distinctive ceramic type indicates that there were occasional contacts and the exchange of materials and information between Central Texas huntergatherers and Mossy Grove peoples to the south and southeast in the Post Oak Savannah, Pineywoods, and probably the upper Texas Gulf Coast (Figure 88).

Creel et al. (2013:74-75) have noted that there are different distributions of Caddo manufactured ceramic vessel sherds in Central Texas sites that have temporal significance. First, they commented that Formative and Early Caddo period ceramics, dating from ca. A.D. 900-1200, are common "in the area from the Brazos River valley around Waco south to the Georgetown area." A total of 34 sites (20.9 percent of the overall site sample) in Central Texas have Formative to Early Caddo period ceramics from plain, utility, and fine ware vessels (Figure 89). The majority of these sites, as Creel et al. (2013) have noted, are in Coryell, Hill, McLennan, and Williamson sites, and these sites are distributed across the Blackland Prairie and the eastern part of the Edwards Plateau. At least two of the sites, Chupik (41ML44) and Asa Warner (41ML46) in the central Brazos River basin, have substantial assemblages of ancestral Caddo ceramic vessel sherds (see Tables 44 and 47), perhaps suggesting more intensive settlement or trade congregations at these two places, as well as some on-site manufacture of Caddo ceramic wares.

During the period from ca. A.D. 1200-1400, ancestral Caddo ceramics of Middle Caddo period decorative styles occur primarily in Blackland Prairie sites ( $n=11$, or 6.8 percent of the overall site sample) in Bell, Bosque, Coryell, Hill, and McLennan counties in the Brazos and Colorado River basins (Figure 90). One site (41TA123) in Taylor County in the Rolling Plains also has Middle Caddo period ancestral Caddo ceramics.

Post-A.D. 1400 Caddo ceramics are much more widespread in Central Texas, and likely relate to both Caddo bison hunting endeavors on the Southern Plains and in Central Texas as well as an intensified period of exchange and interaction between Caddo groups and mobile Central Texas hunter-gatherers. Creel et al. $(2013: 75,77)$ comment that much of the post-A.D. 1400 Caddo ceramics (of the Late Caddo and Historic Caddo periods) in Central Texas are:

considerably more common at sites along streams in the Blackland Prairie just below the Balcones Escarpment, from about the Colorado River (maybe as far as the San Marcos River) north to the Brazos River valley in the vicinity of Waco. Many of these sites have hundreds of sherds representing many Caddo vessels, some Leon Plain and Boothe Brushed sherds, and in some cases, even types from the Gulf Coast. 


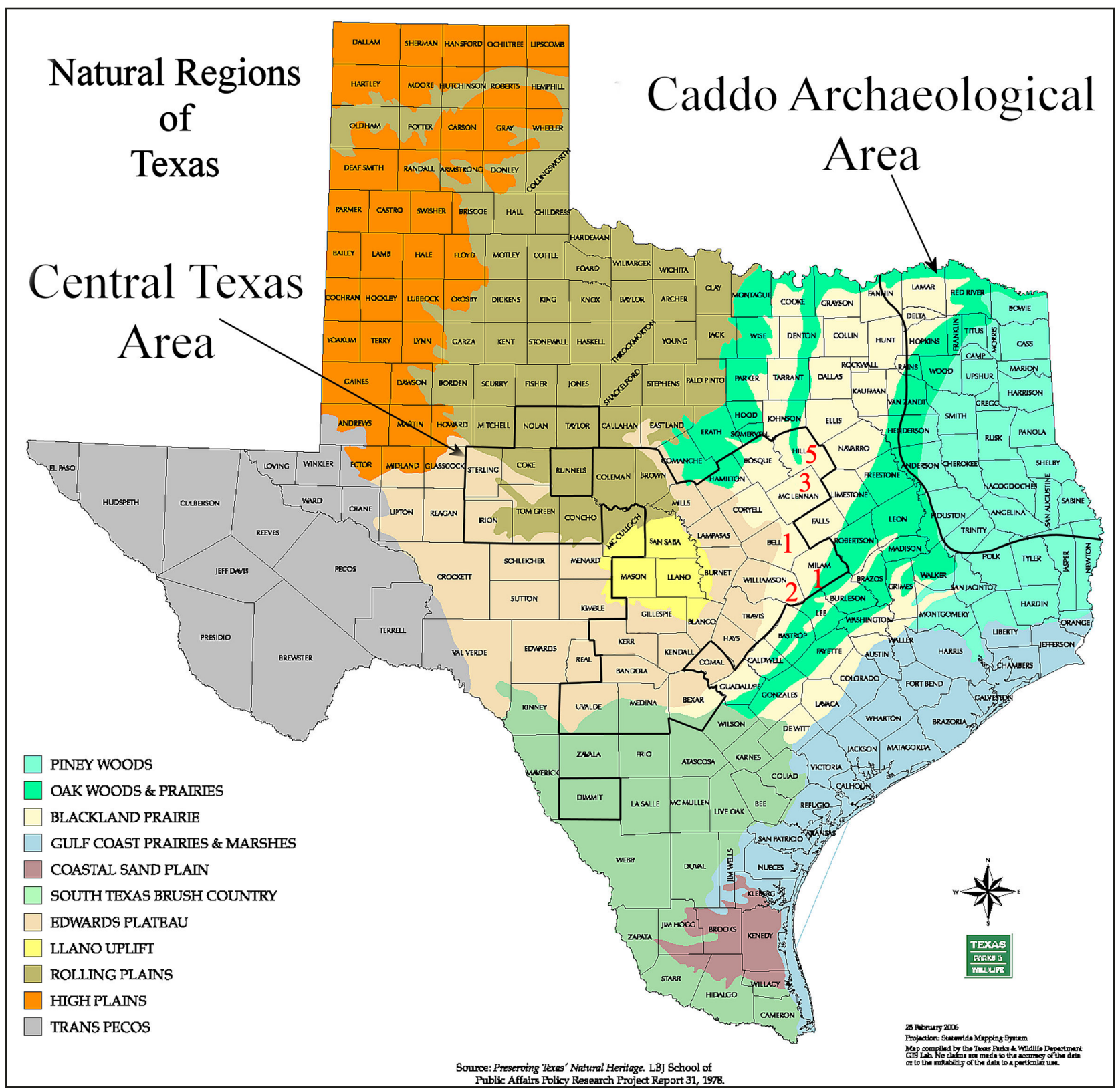

Figure 87. Distribution of sites with Mossy Grove culture Goose Creek Plain, var. unspecified ceramics in Central Texas sites.

Approximately 35 percent of the identified sites in Central Texas with ca. A.D. 1400-1680 ancestral Caddo ceramics have ceramics made by East Texas Caddo potters. They are certainly the most widespread of the different Caddo ceramic assemblages (Figure 91) documented in Central Texas sites, being concentrated in sites in Coryell, Hill, and McLennan counties in the Blackland Prairie and eastern Edwards Plateau. Other nexuses of Late Caddo period ceramics in Central Texas are in Irion and Tom Green counties in the Rolling Plains and western Edwards Plateau (Figure 91), showing a spatial broadening of interaction and exchange networks. 


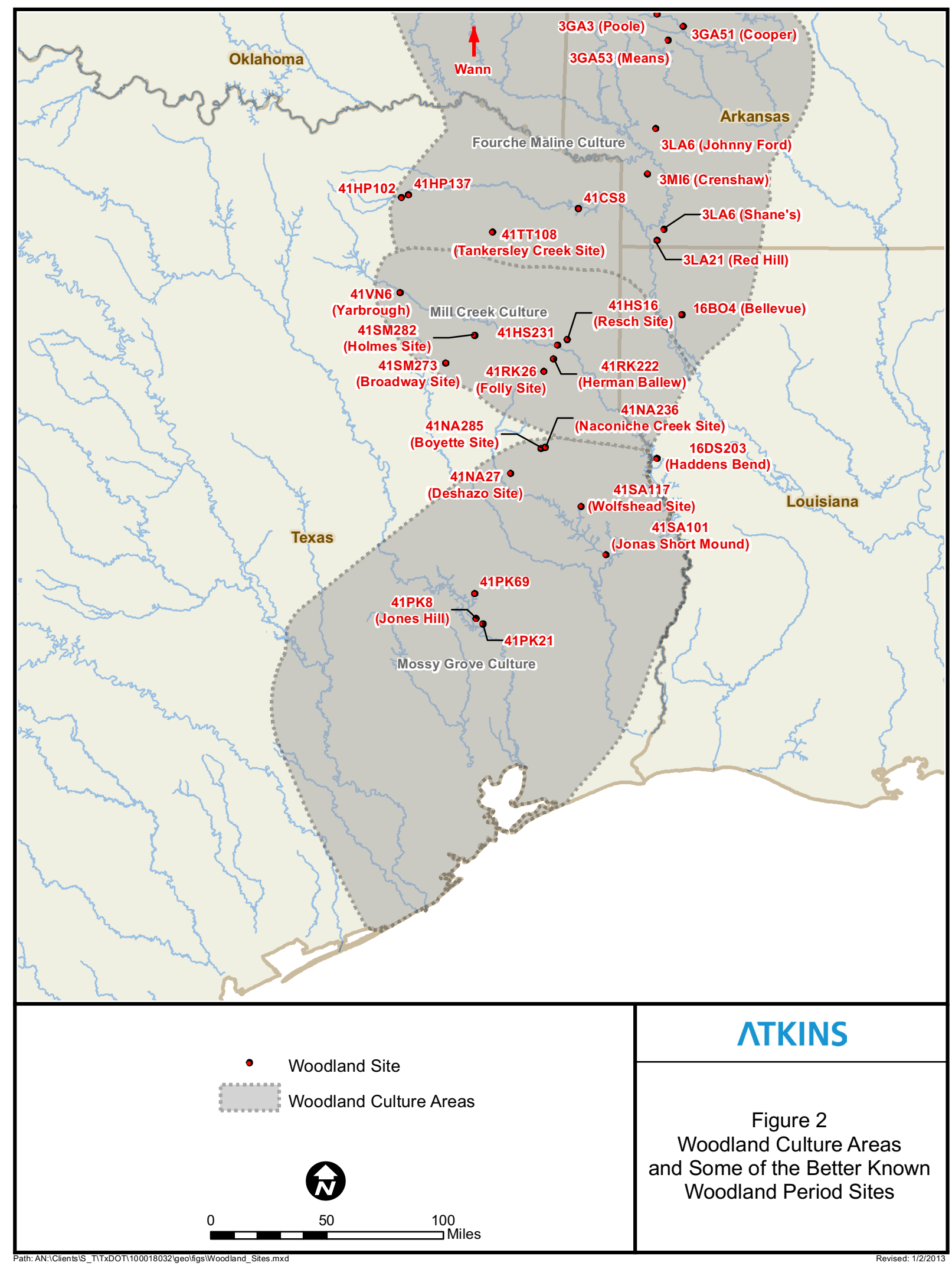

Figure 88. Woodland period sites and cultures in East and Southeast Texas (from Ellis 2013). 


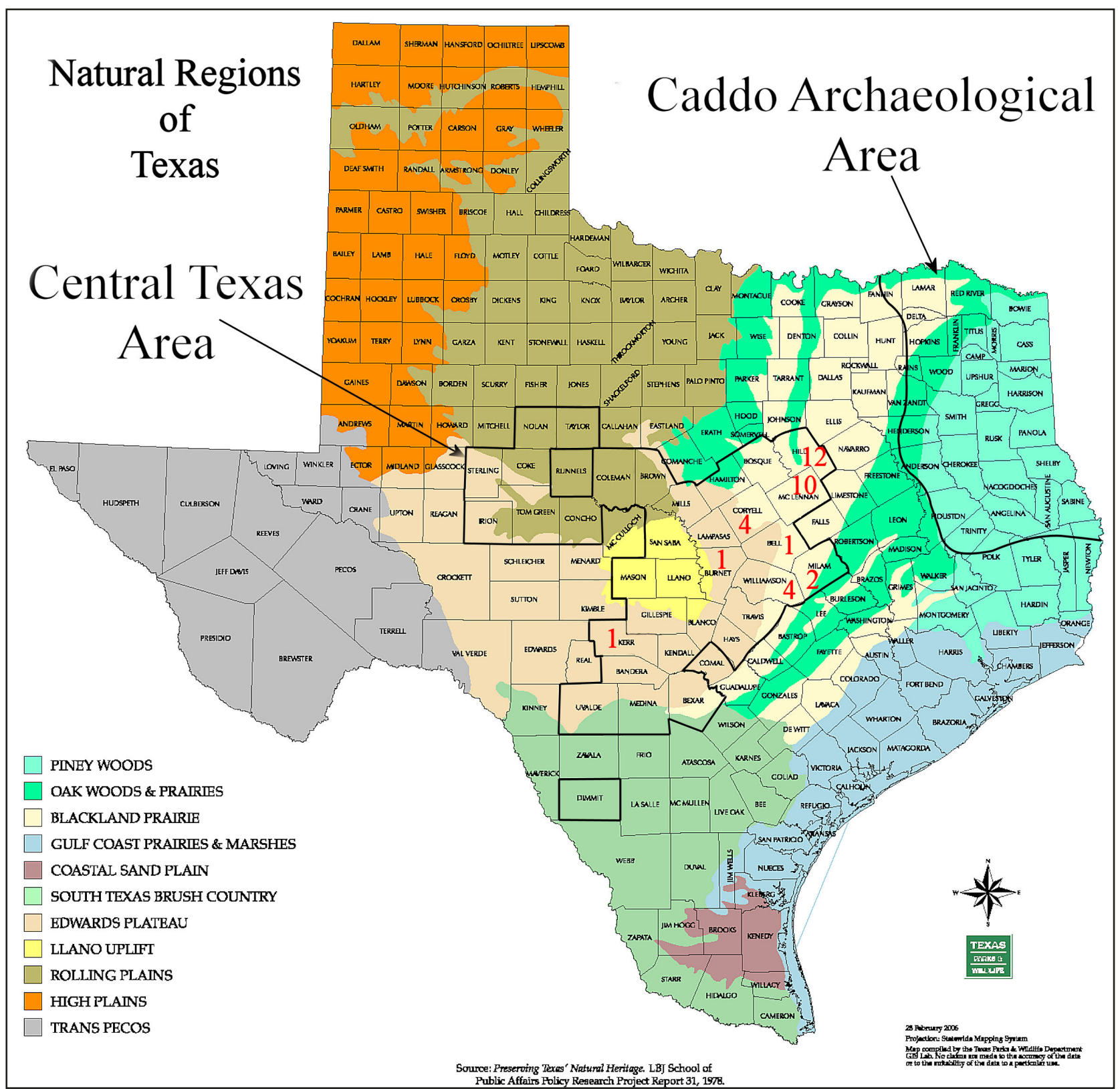

Figure 89. Distribution of sites with ca. A.D. 900-1200 ancestral Caddo ceramics in Central Texas sites.

The majority of the ancestral Caddo ceramics dating from ca. A.D. 1400-1680 were made by Caddo potters in Frankston phase Caddo communities living on the upper and middle Neches River basin in East Texas (Figure 92). This is one of the areas where Hasinai Caddo groups were living after ca. A.D. 1680.

Finally, post-A.D. 1680 ancestral Caddo ceramic vessel sherds are identified on 15 different sites (9.2 percent of the site sample) in Central Texas. These sites are particularly common in McLennan and Hill counties on the Blackland Prairie in the Brazos River basin, where they are associated with historic Wichita settlements (Figure 93). But other sites occur in the Llano Uplift, the Rolling Plains, and the eastern Edwards Plateau. The ancestral Caddo ceramics of post-A.D. 1680 age came either from Caddo settlements on the Red River, or more commonly from settlements in the Allen phase and Hasinai area of the Neches River basin in East Texas (Figure 94; see Perttula 2017d). 


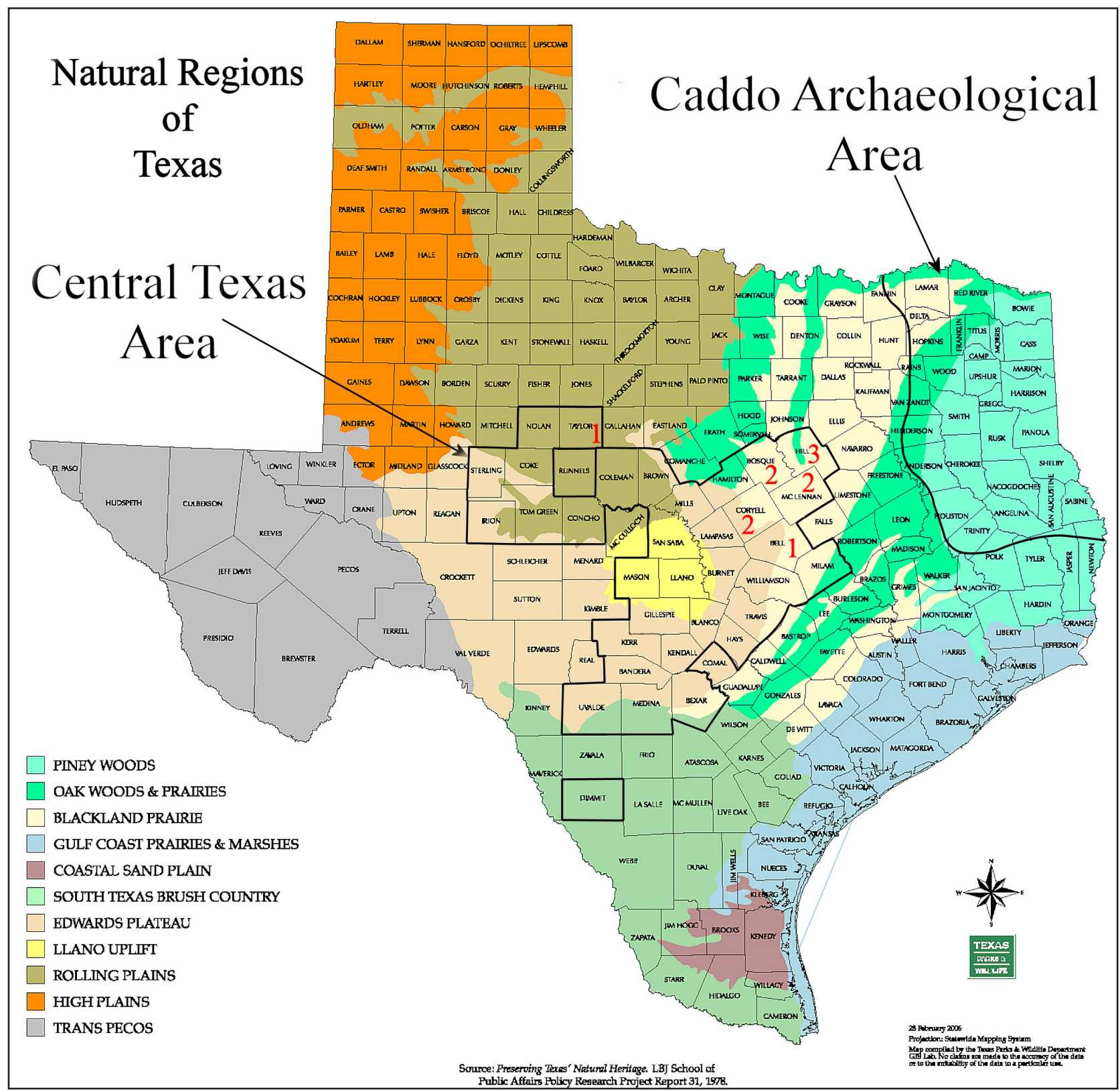

Figure 90. Distribution of sites with ca. A.D. 1200-1400 ancestral Caddo ceramics in Central Texas sites.

By ca. A.D. 1680 East Texas Hasinai or Tejas Caddo and Red River Kadohadacho peoples had horses and this likely led to an expansion of their interaction and exchange networks with non-Caddo peoples, as well as their hunting territories (Barr 2011; Perttula 2017d:Figure 144), fostering the wide distribution of ceramic wares among other goods. According to the Jumano Juan Sabeata in the 1680s, the Hasinai or Tejas were "a settled people [who]...raised grain in such abundance that they even fed it to their horses" (Bolton 1920:314). John (1975:169-170) has noted that "Jumano traders had long bartered Pueblo textiles and turquoise to Caddos, and Caddo bows in turn to Pueblos, as well as their own take of buffalo meat and hides to both village peoples... On their western borders, Caddos held great summer trade fairs, which attracted Jumanos and many other groups annually." The Caddo were in regular contact with aboriginal peoples living in Central Texas, the Southern Plains, and the Southwest, and the goods that were being circulated included ceramic vessels, wood bows, lithic raw materials, and bison hides as well as Spanish products such as horses, horse gear, ornaments, and clothing. 


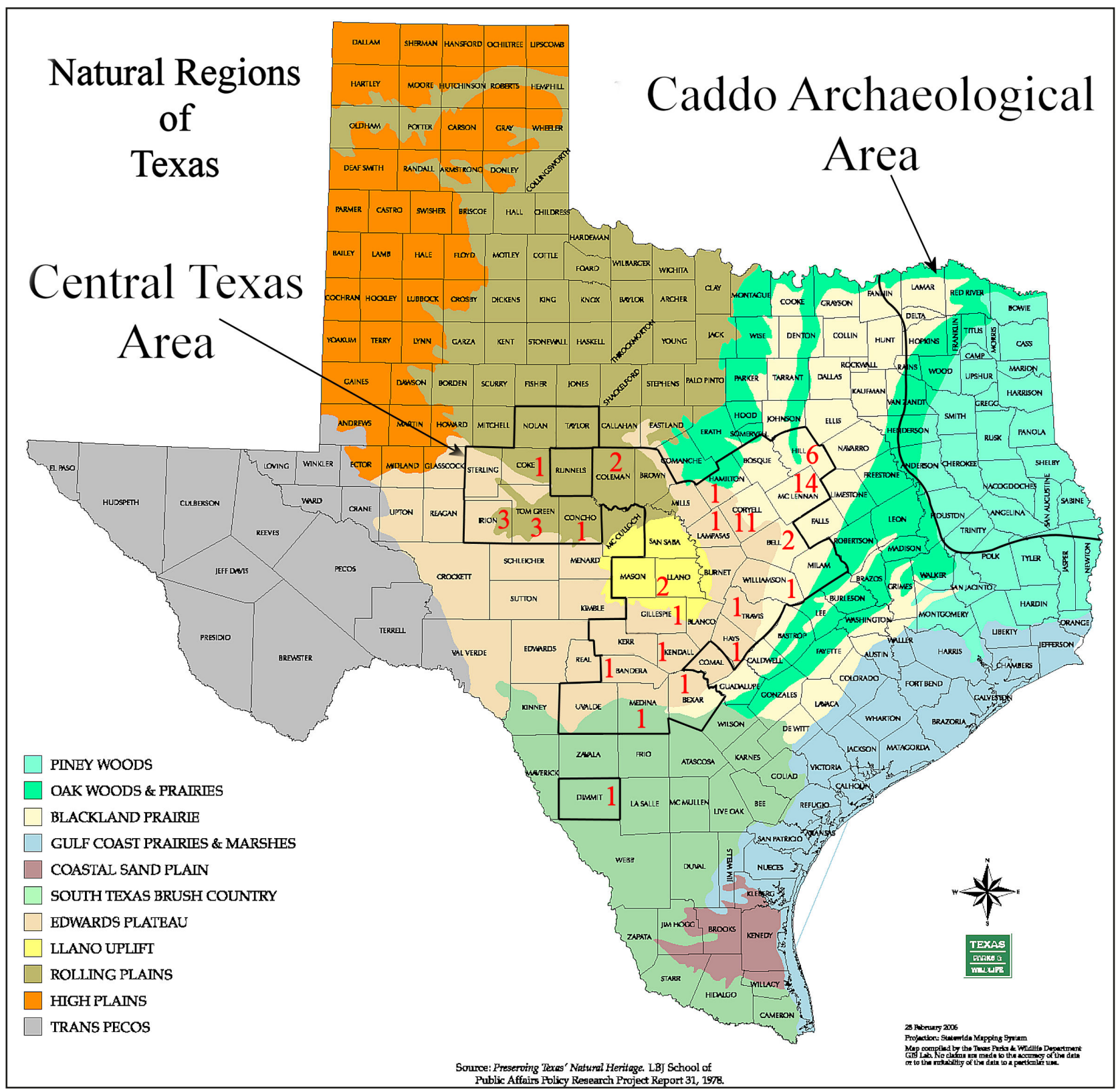

Figure 91. Distribution of sites with ca.A.D. 1400-1680 ancestral Caddo ceramics in Central Texas sites. 


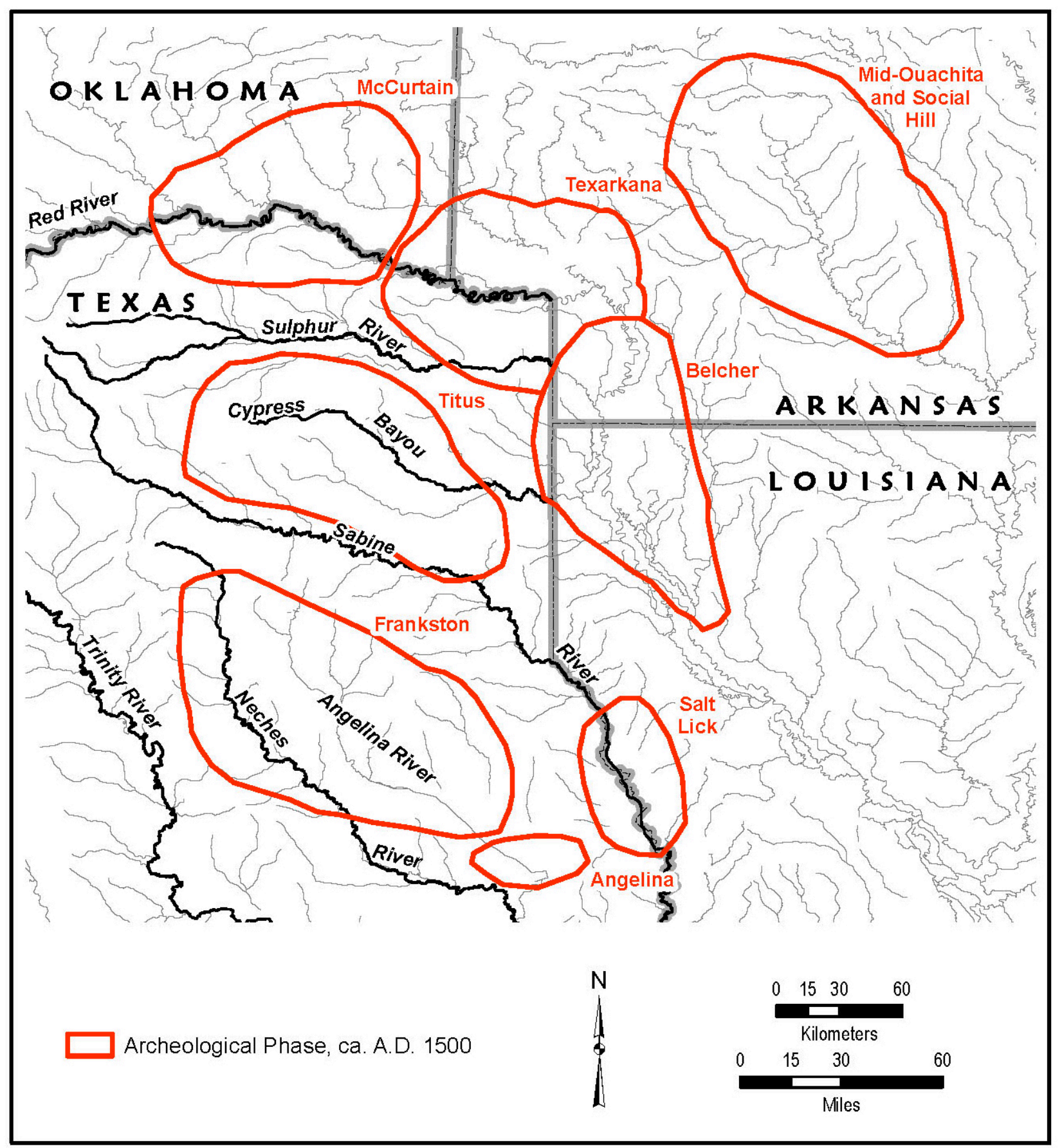

Figure 92. Distribution of recognized Late Caddo period phases in East Texas and the southern Caddo area. 


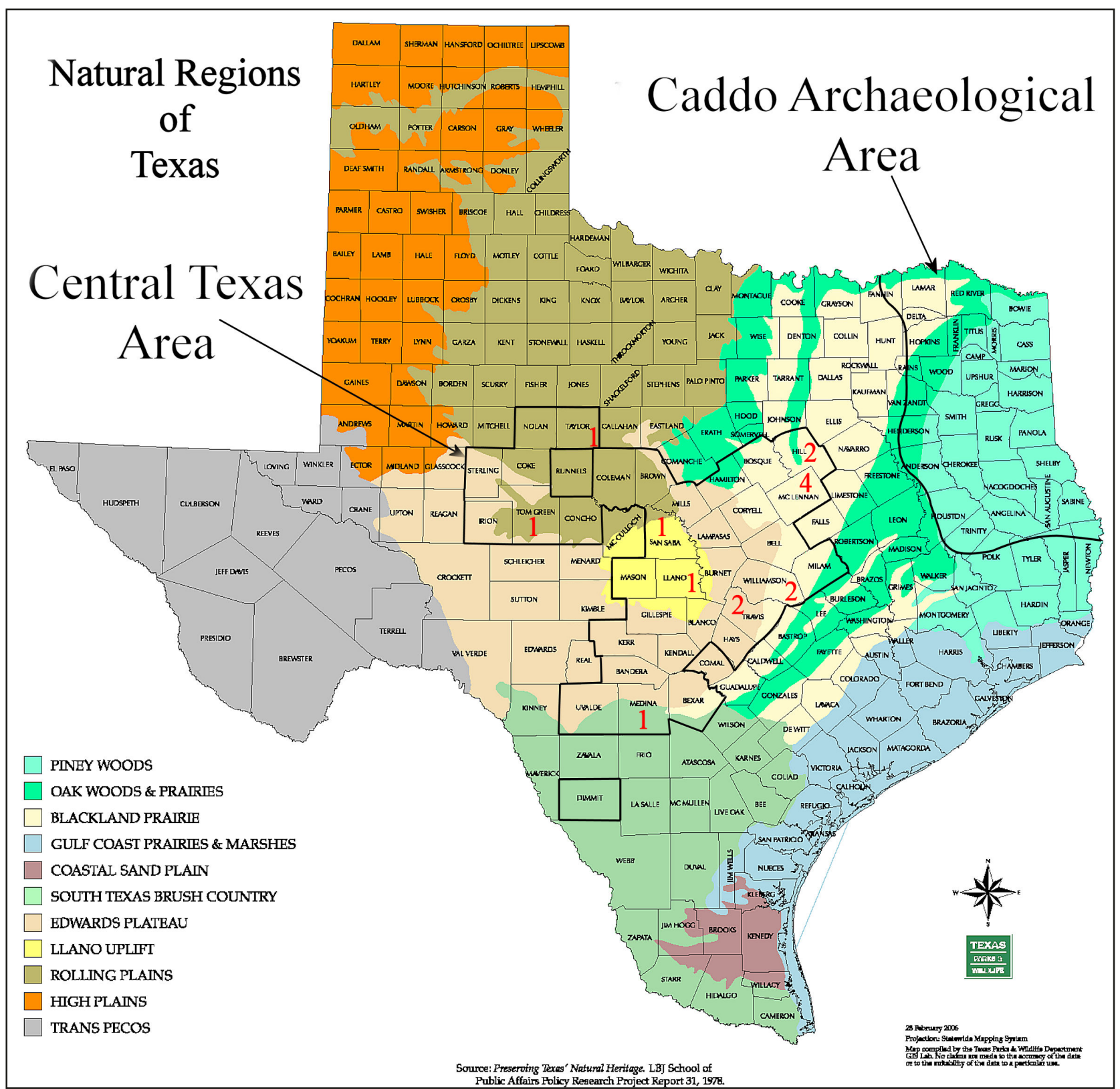

Figure 93. Distribution of sites with ca. post-A.D. 1680 ancestral Caddo ceramics in Central Texas sites. 


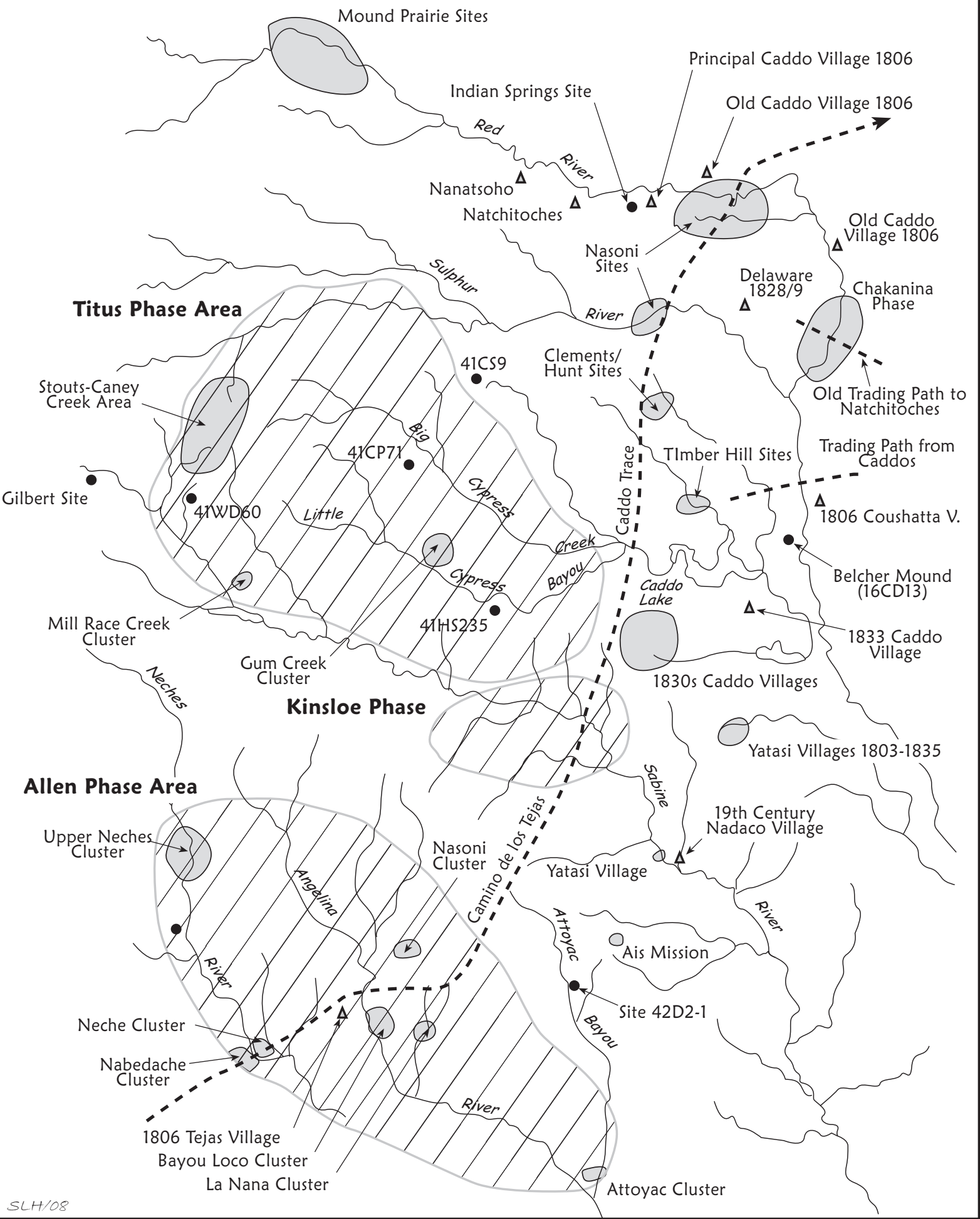

Figure 94. Historic Caddo phases and locales with Historic Caddo settlements in East Texas. 


\section{Prairie Caddo Concept}

The renewed interest in the meaning of the distribution of ancestral Caddo ceramic vessel sherds on Central Texas sites dating after ca. A.D. 900 came from Shafer (2006) and his proposed Prairie Caddo concept. Shafer (2006:5) has suggested that "[a]rguable prehistoric Caddoan [sic] groups occupied the central Brazos valley and its tributaries by A.D. 1100 if not earlier, based on cross-dating artifact styles from the George C. Davis site...Terminal dates are ca. A.D. 1250-1300, based on cross-dating and extant dates" from prehistoric sites in Central Texas. Shafer considers these groups the Prairie Caddo. He goes on to hypothesize that the southern Prairie Caddo (i.e., the central Brazos and its tributaries) permanently occupied "portions of the central Brazos valley with intermittent and interdigitated Caddo presence in the peripheries to the west and south" (Shafer 2006:7).

His hypothesis is that Caddo peoples occupied "the Middle Brazos and its tributaries - especially the Leon and Bosque Rivers and their tributaries" (Shafer 2006:1), and that these Caddo peoples (i.e., southern Prairie Caddo) had connections that were more than the product of trade and exchange with the East Texas Caddo group that settled the George C. Davis site (41CE19) on the Neches River in the East Texas Pineywoods around A.D. 800-900. Specifically, Shafer (2006:4) has argued that these prairie peoples "were affiliated with the George C. Davis site, and ...that the George C. Davis site Caddo were affiliated with the people of the prairie." In this model, the George C. Davis site was a major regional center between ca. A.D. 1000-1300 and "attracted visitors from adjacent and distant regions," including the Central Texas prairies, especially because of feasting events and ritual activities (Shafer 2006:9-10, 33). Shafer (2006:32) characterizes the site as a "gateway to the prairies."

It has been further suggested by Shafer (2006:10) that Caddo ceramics made at the George C. Davis site were moving or being exported to outlying settlements in the southern Prairie Caddo area. This pottery was thought to have been obtained during feasting activities at the George C. Davis site, and then apparently carried back to Central Texas and used "essentially for domestic roles" (Shafer 2006:26). He also suggests that "the absence of fine engraved pottery would be expected in small hunting camps," while larger villages on the Brazos and various tributaries would have a "variety of vessels in both form and decoration" (Shafer 2006:10).

One of the important attributes in recognizing Prairie Caddo sites is Early Caddo period pottery, obviously, but pottery that was produced by local Caddo groups on the prairie, and thus not representing trade goods from Caddo peoples to Central Texas groups. As Shafer (2006:25) notes, most of the Caddo pottery found on Central Texas sites is either grog- or bone-tempered, perhaps the product of "two different technological styles" among Caddo potters. The pottery from the George C. Davis site is primarily grog-tempered (see Newell and Krieger 1949), but bone-tempered Caddo pottery is common in several areas in East Texas (see Perttula 2015a:Figure 11), most notably in the Angelina and mid-Sabine River areas, but especially after ca. A.D. 1400.

While not found in great numbers, engraved sherds (as well as sherds with different decorative methods) from vessels of apparent Caddo origin have been found at a number of sites in Central Texas (see Watt 1953; Jelks 1962; Sorrow et al. 1967; Stephenson 1970; Ricklis and Collins 1994; Turner 1997; Perttula et al. 2003; Shafer 2006), particularly sites "restricted to the eastern margin of the Edwards Plateau and the prairie environment immediately to the east and northeast of the plateau" (Ricklis and Collins 1994:305 and Figure 155). Creel et al. (2013:66) corroborate this distribution in their INAA study of ceramics from Central Texas sites, noting that "essentially all Caddo pottery samples with substantial probabilities of membership in a Central Texas compositional group (as well as in Caddo chemical compositional groups)" are from the Waco, Belton, to Austin area, mostly from the vicinity of 
Waco, Temple, and Belton (see Figures 89-91 and 93). These engraved wares, and other decorated wares, are from contexts that in East Texas Caddo sites would date from Early Caddo (ca. A.D. 900-1200) to Historic Caddo (ca. A.D. 1680-1800) times, but with an apparent peak in Caddo style engraved pottery in Central Texas prairie sites dating before ca. A.D. 1300 (cf. Shafer 2006). My review of the 163 sites in Central Texas that have Caddo ceramic vessel sherds indicate that engraved pottery is just as common after ca. A.D. 1400 as it is before A.D. 1300, however.

Pottery on Central Texas sites is "not nearly as common in prairie sites as they are in sites in the Caddo heartland" (Shafer 2006:25), likely because of mobility and transportation constraints on these Prairie Caddo groups, since they were relatively mobile hunter-gatherers. According to Shafer (2006:25):

Ceramics, while often used, played a far less significant role than in the sedentary sites in the Caddo heartland. Jars were used for cooking and, when broken, were not replaced as they were in the heartland. Bottles carried as canteens were broken in village and outlier sites, and likewise not replaced. The general paucity of ceramics in Prairie Caddo sites is partly due to the fact that there was no replacement rate for the imported styles. It remains to be demonstrated that locally made ceramics replaced broken imported vessels.

What Shafer (2006:25) suggests is that "Caddo parties leaving Davis after ceremonial occasions [and returning to the Central Texas prairies] brought pottery with them obtained through various mechanisms of exchange and used the pottery essentially for domestic roles." He further suggests that the analysis of the ceramic assemblages from prairie Caddo sites should:

look for the presence of fine engraved pottery in central Texas collections. The absence of fine engraved pottery would be expected. Central Texas sites are mostly small campsites that were probably short-term hunting and gathering localities. Ceramics in such instances would be for practical rather than presentational purposes. Jars that are either plain or with wet-paste decorations for practical uses around the hearth would be expected (Shafer 2006:38).

This East Texas Caddo pottery found on Central Texas Prairie Caddo sites ought to be identifiable, among various analyses, through a comparison of ceramic decorative motifs and elements from the George C. Davis site to the Prairie Caddo sites, as well as through the instrumental neutron activation analysis (INAA) and petrographic analysis of a sample of pottery sherds from the George C. Davis site (see Descantes et al. 2005; Perttula 2017b) and ceramic sherds with Early Caddo period styles from Prairie Caddo sites (see Shafer 2006:26).

Shafer (2006) has suggested that Prairie Caddo artifact assemblages dating before ca. A.D. 1200 (including Caddo style ceramics, large Gahagan bifaces, beaming tools, bone pins, and Alba-Bonham arrow points) are most common in the area between the Brazos and Colorado rivers in Central Texas counties; post-A.D. 1400 Caddo style ceramics are also found there. Boyd et al. (2014:133) comment on how there must have existed social boundary maintenance practices and traditions between western Caddo and eastern Edwards Plateau hunter-gatherer groups at different times, and to account for Caddo pottery sherds in Central Texas areas they posit that (1) Caddo groups were present on the Blackland Prairie for bison hunts; (2) Caddo groups were just one of a number of groups that encamped in this area: (3) a defined boundary zone may have been present that was occasionally marked by interpersonal violence. Carpenter et al. $(2010: 102,106)$ posit the emergence of complex regional integration of Caddo and non-Caddo Central Texas peoples after ca. A.D. 800 in response to both climatic and cultural environmental changes. 
More recently, Carpenter (2017; see also Carpenter et al. 2012:233-246, 255, 260-262) has argued that post-A.D. 1250 Toyah phase sites and artifact assemblages "emerged from a Caddo material culture in a small area on the Brazos River" (Carpenter et al. 2012:233) and that "the Toyah toolkit was likely employed by the Caddo, Jumano, and Rockport peoples, among others, on a seasonal basis for shortterm, long-range territorial mobility when targeting high-ranked resources" (Carpenter 2017:138). This argument is hard to credit given the considerable differences that exist between Toyah ceramics - plain bone-tempered bowls, jars, and ollas - and ancestral Caddo ceramics of the same ages: grog, bone, and hematite-tempered vessels of many forms and sizes, the majority of which have wet paste decorations on utility ware vessels and engraved and slipped decorations on fine ware vessels, unless one accepts the idea that Toyah pottery was used by Caddo potters for "ad hoc purposes" (Carpenter 2017:148), such as grease rendering, and chose not to use their utility wares and fine wares for such purposes. A problem with this argument is that ancestral Caddo utility and fine ware ceramic vessel sherds are present in these same Toyah sites, where they obviously had been in use, but have been sourced to East Texas production locales. If Caddo groups were bringing their ceramic vessels from their East Texas settlements, would not they have been used as appropriate for tasks associated with bison hunting, procurement, and processing? A more parsimonious argument is that Toyah and ancestral Caddo pottery were made by different peoples in different locales, one likely of non-Caddo ethnic origin (Toyah pottery) and made locally in Central Texas, and Caddo pottery made in East Texas settlements were used on Toyah sites like Leon Plain wares were.

Lastly, Carpenter (2017:151) asserts that there are connections between Caddo groups and Toyah area sites because they share "basic stylistic and technological traits, such as bone-tempered ceramics." While some ancestral Caddo pottery is commonly tempered with burned bone (Perttula 2015a:Figure 11), as is Leon Plain in Toyah assemblages, there the similarities end. Typically, Toyah ceramics are more than 95 percent bone-tempered, while Caddo assemblages when they are bone-tempered typically have no more than 40-50 percent bone-tempered vessel sherds. But it is stylistically that Toyah and Caddo ceramics are quite different: Toyah wares are plain wares (see Kenmotsu and Boyd 2012:12-13), while ancestral Caddo wares have wet paste and dry paste decorations of considerable complexity and symbolic meaning. It would not be easy to trace the evolution of Toyah ceramics from an ancestral Caddo ceramic tradition that began more than 350 years before Toyah complexes even existed. However, it is considered likely that Toyah folks gained knowledge about ceramic technology from ancestral Caddo populations, and that the adoption of pottery, as among other hunter-gatherers (cf. Finley et al. 2017), may have been the result of economic intensification associated with hot rock cooking and the procurement and processing of bison hides and meat for more than 450 years (ca. A.D. 1250-1700).

\section{Other Perspectives}

Another possibility is that Caddo vessels manufactured in a number of different regions in East Texas (see Perttula et al. 2003:Figure 16) were only very occasionally traded or exchanged for various reasons (not just feasting) with aboriginal hunter-gatherer groups whose territorial range included the Central Brazos river basin. These same hunter-gatherer groups, many affiliated with the Toyah phase, did make their own pottery, likely inspired by Caddo pottery then in use (cf. Johnson 1994:242; Creel et al. 2013:32), primarily a plain bone-tempered ware as well as probably a brushed-punctated utility ware (Boothe Brushed) that closely resembles Bullard Brushed in character. On the basis of a stylistic, petrographic, and chemical analysis of sherds from 11 Central Texas sites (Perttula et al. 2003:Figure 1), Perttula et al. (2003:63) concluded that:

The generally low number of Caddoan [sic] pottery sherds found on many central Texas sites, and the fact that the pottery was not made from central Texas clays, indicates that the sherds are from vessels traded to local central Texas hunter-gatherers, not vessels produced by Caddoan [sic] peoples who had settled in or were periodically using the central Texas region. 
Fields (2017:16-17) has suggested that the movement of Caddo pottery westward from East Texas into Central Texas communities is associated with the eastward movement of arrow points and knives manufactured from high quality Central Texas lithic raw materials, and that the "pattern of connection between the eastern margin of central Texas and the eastern part of the state was a persistent one rooted in long-held traditions." These traditions are the product of interaction, exchange, and trade between nonCaddo and ethnically Caddo peoples, not between East Texas Caddo peoples and Prairie Caddo peoples. Fields (2017:18) also points out that the benefits of trade between these different peoples was to help establish cooperative alliances, and reduce competition and violence in the region, and that such alliances were established and maintained by the Caddo over a long period of time, not just during the ca. A.D. 1100-1300 putative period of the Prairie Caddo:

Such alliances could have allowed the Caddo free rein for trips west of their homeland to hunt bison, as well as to procure the coveted arrow tips and knife blades, and congregate with other people for trade at certain locales near the Balcones Escarpment.

Two such likely places of group congregation in Central Texas, namely the Chupik (41ML44) and Asa Warner (41ML46) sites (see Fields 2017:18), both have a relatively abundant assemblage of Caddo ceramic vessel sherds that represent long-term use of these places. At Chupik, for example, the decorated ceramics suggest use of the site primarily before ca. A.D. 1200, but there is evidence of post-A.D. 1200 use there, while at the Asa Warner site, the ceramics are primarily from a ca. A.D. 1200-1300 component, but there is evidence in the decorated sherds for use at the site after ca. A.D. 1400 and after ca. A.D. 1680. Surely there are other trade congregation sites not yet identified in the sample of sites in Central Texas discussed herein with ancestral Caddo ceramics.

Toyah phase sites with bison occur in a number of spatial clusters in Central and South Texas (see Mauldin et al. 2012:Figure 5.1 and Table 5.2; Mauldin et al. 2010:Figure 8.6; Carpenter et al. 2012:Figure 13.8), particularly sites in the Brazos and Colorado River basins east of the Balcones Escarpment and in the Edwards Plateau. Where the bison bone has been directly dated, the bison dates to two periods, ca. A.D. 1300-1450 and A.D. 1630-1800 (Jon Lohse, February 2018 personal communication). Ancestral Caddo vessel ceramics occur on a number of these Toyah sites, and as previously noted, most of the ceramics on these sites date after ca. A.D. 1400. It seems likely that the occurrence of post-A.D. 1400 Caddo ceramics on Central Texas sites represent material evidence of the interaction, exchange, and trade between certain Central Texas hunter-gatherers and Caddo farmers that were engaged in bison hunting and/or trade for meat, hides, and bone tools on the Central Texas landscape. Bison hunting provided different aboriginal populations in East and Central Texas a considerable opportunity for interaction, exchange, and trade of other goods (such as ceramic vessels made by East Texas Caddo potters) through the $15^{\text {th }}, 16^{\text {th }}, 17^{\text {th }}$, and $18^{\text {th }}$ centuries, if not beyond.

In East Texas Caddo sites with bison $(\mathrm{n}=24)$, bison remains are much more common in Caddo sites in East Texas dating after ca. A.D. 1430 (see Perttula 2015c:Table 1). Five sites (21 percent), were occupied between ca. A.D. 1430-1550, and another four sites (17 percent) were occupied between ca. A.D. 1550-1690. One other Late Caddo site in East Texas with bison has only broader temporal estimates, unfortunately: being occupied between ca. A.D. 1430-1680. This period is also the time when Caddo pottery is more common in areas of Central and East Central Texas where Caddo groups were hunting bison (Creel et al. 2013:74). In the historic Caddo period, four of the East Texas sites with bison bones (17 percent) were occupied between ca. A.D. 1680-1750. The last of the known Caddo sites in East Texas with bison bones was occupied between ca. A.D. 1750-1775. 
Historic records concerning the Caddo exploitation of bison are illuminating as various Spanish accounts indicate that from the 1690 s to the mid- $18^{\text {th }}$ centuries, if not earlier as well as later, East Texas Caddo groups had been hunting bison herds between the Trinity and Colorado rivers in prairie habitats (Foster 1995:40, 112). Fray Casanas, who lived among the Hasinai Caddo groups in East Texas in 1690, noted that the Caddo men traveled west (in the Brazos and Colorado River basins) to hunt bison (Casanas 1968:44; Creel et al. 2013:75). Sites with Historic Caddo ceramic vessel sherds are present in both river basins (see Figure 93). The cooler and wetter climates at that time period created vegetation conditions "sufficient to sustain sizeable herds of the large animals" (Foster 1995:236). In 1768, Solis noted that bison herds were not found east of the Trinity River. Earlier, Nasoni Caddo hunters from Red River communities had taken 46 bison during a two-week hunt in 1719 north of the Red River in the Kiamichi River valley in southeastern Oklahoma (Smith 1959:382). In later historic times among the Kadohadacho, namely in the early $19^{\text {th }}$ century (before 1830), bison were noted to occur in large herds in the Bodcau Prairie in the Red River basin in Northwestern Louisiana (Webb 1959:10). 


\section{References Cited}

Abbott, J. T. and W. N. Trierweiler (editors)

1995 NRHP Significance Testing of 57 Prehistoric Archeological Sites on Fort Hood, Texas. 2 Vols. Archeological Resource Management Series, Research Report No. 34. United States Army Fort Hood, Fort Hood, Texas.

Arnold, D. E.

2008 Social Change and the Evolution of Ceramic Production and Distribution in a Maya Community. University Press of Colorado, Boulder.

Assad, C. and D. R. Potter

1979 An Intensive Archaeological Survey of Enchanted Rock State Natural Area, Llano and Gillespie Counties, Texas. Archaeological Survey Report No. 84. Center for Archaeological Research, The University of Texas at San Antonio.

Aten, L. E. and C. N. Bollich

2002 Late Holocene Settlement in the Taylor Bayou Drainage Basin: Test Excavations at the Gaulding Site (41JF27), Jefferson County, Texas. Studies in Archeology 40, Texas Archeological Research Laboratory, The University of Texas at Austin, and Special Publication No. 4, Texas Archeological Society, San Antonio.

Atlee, W. A.

2004 Caddoan Ceramics and Associated Artifacts from Cement Hill Site No. 2 (41ML66), McLennan County, Texas. The Record 51:1-13. Dallas Archeological Society, Dallas.

Barkwill-Love, L.

n.d. Petrographic Analysis of Pottery Sherds from 41HM51. MS on file, Prewitt and Associates, Inc., Austin.

Barr, J.

2011 Geographies of Power: Mapping Indian Borders in the "Borderlands" of the early Southwest. William and Mary Quarterly 68(1):5-46.

Beach, S. D.

2015 Wichita Women and Their Roles in the World Economy: How Postcontact Ceramics Inform Culture Change in the Southern Plains. Master's thesis, Department of Anthropology, University of Oklahoma, Norman.

Bell, R. E. and T. Bastian

1967 Preliminary Report upon Excavations at the Longest Site, Oklahoma. In A Pilot Study of Wichita Indian Archeology and Ethnohistory, assembled by R. E. Bell, E. B. Jelks, and W. W. Newcomb, pp. 54-118. Final Report for Grant GS-964, National Science Foundation, Washington, D.C.

Bell, R. E., E. B. Jelks, and W. W. Newcomb (assemblers)

1967 A Pilot Study of Wichita Indian Archeology and Ethnohistory. Final Report for Grant GS-964, National Science Foundation, Washington, D.C. 
Black, S. L.

1986a The Clemente and Herminia Hinojosa Site, 41JW8: A Toyah Horizon Campsite in Southern Texas. Special Report No. 18. Center for Archaeological Research, The University of Texas at San Antonio.

1986b Prehistoric Ceramics. In The Prehistoric Sites at Choke Canyon Reservoir, Southern Texas: Results of Phase II Archaeological Investigations, by G. D. Hall, T. R. Hester, and S. L. Black, pp. 337-391. Choke Canyon Series, Volume 10. Center for Archaeological Research, The University of Texas at San Antonio.

Black, S. L., L. W. Ellis, D. G. Creel, and G. T. Goode

1997 Hot Rock Cooking on the Greater Edwards Plateau: Four Burned Rock Midden Sites in West Central Texas. Studies in Archeology 22, 2 Vols. Texas Archeological Research Laboratory, The University of Texas at Austin.

Bolton, H. E.

1920 The Spanish Borderlands: A Chronicle of Old Florida and the Southwest. Yale University Press, New Haven.

Bond, C. L.

1978 Three Archeological Sites at Hoxie Bridge, Williamson County, Texas. Report No. 43. Anthropology Laboratory, Texas A\&M University, College Station.

Boyd, D. K., J. E. Dockall, K. W. Kibler, G. Mehalchick, and L. M. Short

2014 Data Recovery Investigations at the Tank Destroyer Site (41CV1378) at Fort Hood, Coryell County, Texas. Reports of Investigations No. 172, Prewitt and Associates, Inc. and Report No. 149, Archeological Studies Program, Texas Department of Transportation, Austin.

Brown, D. O. (compiler)

1987 Archeology at Aquilla Lake: 1978-1982 Investigations. 3 Vols. Research Report 81. Texas Archeological Survey, The University of Texas at Austin.

Brown, D., R. Watson, D. Peter, and V. Rawn-Schatzinger

1987 The McDonald Site-41HI105. In Archeology at Aquilla Lake: 1978-1982 Investigations, compiled by D. O. Brown, pp. 38-1 to 38-145. 3 Vols. Research Report 81. Texas Archeological Survey, The University of Texas at Austin.

Bryan, F.

1935 A Resume of the Prehistoric Human Cultural Remains so far Discovered in Central Texas. Bulletin of the Central Texas Archeological Society 1:5-10.

1936 Preliminary Report on the Archeology of Western Limestone County. Bulletin of the Central Texas Archeological Society 2:81-92.

1937 A Preliminary Report on the Archeology of Western Navarro County and some Camp Sites in Hill and McLennan Counties. Central Texas Archeologist 3:70-79. 
Carpenter, S. M.

2017 The Toyah complex of south and central Texas: Long-range mobility and the emergence of dual economies. Plains Anthropologist 62(242):133-156.

Carpenter, S., C. T. Hartnett, J. D. Lowe, and K. A. Miller

2010 Data Recovery Investigations on the Cowdog Crossing Site: A Study of the End of the Archaic, Fort Hood, Coryell County, Texas. Research Report No. 56. Archeological Resource Management Series, United States Army Fort Hood, Texas.

Carpenter, S. M., K. A. Miller, C. D. Frederick, L. G. Cecil, M. C. Cody, and A. Peyton

2012 The Little Paint Site: A Classic Toyah Camp on the South Llano River, Kimble County, Texas. Report No. 148. Archeological Studies Program, Texas Department of Transportation, and Report No. 12-429. SWCA Cultural Resources Report, SWCA Environmental Consultants, Austin.

Casanas, F.

1968 Relacion sobre los indios del este de Texas. In Primeras Exploraciones y Poblamiento de Tejas (1686-1694), Noticias Geograficos e Historicas del Noreste de Mexico, edited by L. Gomez Canedo, pp. 39-69. Instituto Technologico y de estudios superiors de Monterrey, Mexico.

Chandler, C. K.

1995 A Ceramic “T”-Shaped Pipe from Kerr County, South Central Texas. La Tierra 22(3):24-28.

Cook, G. and J. Dunbar

2008 Mapping an Eighteenth-Century Wichita Village Site. In "Land of Our Ancestors: Studies in Protohistoric and Historic Wichita Cultures," edited by T. G. Baugh and S. M. Perkins, pp. 487502. Memoir 40, Plains Anthropologist 53, No. 208.

Creel, D.

1990 Excavations at 41TG91, Tom Green County, Texas, 1978. Publications in Archaeology Report No. 38. Highway Design Division, Texas State Department of Highways and Public Transportation, Austin.

Creel, D., J. R. Ferguson, and N. A. Kenmotsu

2013 A Compositional Analysis of Central Texas Hunter-Gatherer Ceramics and Its Implications for Mobility, Ethnic Group Territory, and Interaction. Bulletin of the Texas Archeological Society 84:29-83.

Descantes, C., D. Creel, R. J. Speakman, S. Wilson, and M. D. Glascock

2005 Instrumental Neutron Activation Analysis of Pottery from the George C. Davis Site, Texas. North American Archaeologist 25(2):121-138.

Dillehay, T. D.

1972 An Experimental Comparative Approach to Primitive Ceramic Materials from the Chupik Site (41ML44) and Nearby Raw Clay Sources in McLennan County, Texas. MS on file, Texas Archeological Research Laboratory, The University of Texas at Austin. 
Duffield, L. F. and E. B. Jelks

1961 The Pearson Site: A Historic Indian Site in Iron Bridge Reservoir, Rains County, Texas. Archelogy Series No. 3. Department of Anthropology, University of Texas, Austin.

Ellis, L. W.

1997 Prehistoric Ceramics. In Hot Rock Cooking on the Greater Edwards Plateau: Four Burned Rock Midden Sites in West Central Texas, by S. L. Black, L. W. Ellis, D. G. Creel, and G. T. Goode, pp. 560. Studies in Archeology 22, 2 Vols. Texas Archeological Research Laboratory, The University of Texas at Austin.

2013 Woodland Ceramics in East Texas and a Case Study of Mill Creek Culture Ceramics. Bulletin of the Texas Archeological Society 84:137-180.

Feathers, J. K.

2003 Use of Luminescence Dating in Archaeology. Measurement Science and Technology 14:14931500 .

Ferguson, J. R. and M. D. Glascock

n.d. Neutron Activation Analysis of Toyah Ceramics from 41HM51, Hamilton County, Texas (GST238-248): A comparison to the recent study of over 600 Central Texas ceramics previously analyzed by NAA. Archaeometry Laboratory, Research Reactor Center, University of Missouri, Columba. MS on file, Prewitt and Associates, Inc., Austin.

Field, A.

1956 Archeological Investigations in Lampasas, Burnet, Llano, and San Saba Counties, Texas. Bulletin of the Texas Archeological Society 27:161-184.

Fields, R. C.

2017 The Prairie Caddo Model and the J. B. White Site. Caddo Archeology Journal 27:5-19.

Finley, J. B., C. J. Ideker, and T. Rittenour

2017 Single-Grain Optically Stimulated Luminescence Ages of Brownware Pottery in the Middle Rocky Mountains and the Spread of Numic Ceramic Technology. American Antiquity 82(4):761780.

Flynn, P.

1976 A Study of Red-Filmed Pottery from the Clement Site (Mc-8), McCurtain County, Oklahoma. Bulletin of the Oklahoma Anthropological Society 25:127-134.

Forrester, R. E.

1985 Horn Shelter Number 2: The North End, A Preliminary Report. Central Texas Archeologist 10:21-35.

Foster, W. C.

1995 Spanish Expeditions into Texas, 1689-1768. University of Texas Press, Austin.

Fox, A. A. and K. M. Ulrich

2008 A Guide to Ceramics from Spanish Colonial Sites in Texas. Special Publication No. 33. Center for Archaeological Research, The University of Texas at San Antonio. 
Gadus, E. F.

n.d. Descriptions of Ceramics from Data Recovery and Test Excavations at the Jayroe Site (41HM51). MS on file, Prewitt and Associates, Inc., Austin.

Gadus, E. F., R. C. Fields, and K. W. Kibler

2006 Data Recovery Excavations at the J. B. White Site (41MM341), Milam County, Texas. Reports of Investigations No. 145. Prewitt and Associates, Inc., Austin.

Girard, J. S., T. K. Perttula, and M. B. Trubitt

2014 Caddo Connections: Cultural Interactions Within and Beyond the Caddo World. Rowan \& Littlefield, Lanham, Maryland.

Green, L. M. and T. R. Hester

1973 The Finis Frost Site: A Toyah Phase Occupation in San Saba County, Central Texas. Bulletin of the Texas Archeological Society 44:69-88.

Greer, J. W.

1976 Neo-American Occupation at the Wheatley Site, Pedernales Falls State Park, Blanco County, Texas. Bulletin of the Texas Archeological Society 47:89-169.

Griffith, T. B., K. W. Kibler, and D. K. Boyd

2010 National Register Testing at 41BQ285, Bosque County, Texas: FM 56 Bridge Replacement at the North Bosque River. Reports of Investigations No. 160. Prewitt and Associates, Inc., Austin.

Harris, R. K., I. M. Harris, J. C. Blaine, and J. Blaine

1965 A Preliminary Archeological and Documentary Study of the Womack Site, Lamar County, Texas. Bulletin of the Texas Archeological Society 36:287-363.

Hart, J. P.

2014 An Analysis of the Aboriginal Ceramics from the Washington Square Mound Site, Nacogdoches County, Texas. Stephen F. Austin State University Press, Nacogdoches.

Hartley, J. D. and A. F. Miller

1977 Archaeological Investigations at the Bryson-Paddock Site: An Early Contact Period Site on the Southern Plains. Archaeological Site Report No. 32. Oklahoma River Basin Survey, University of Oklahoma Office of Research Administration, Norman.

Hays, T. R. (editor)

1982 Archaeological Investigations at the San Gabriel Reservoir Districts, Central Texas. Vols. 1-3. Institute of Applied Sciences, North Texas State University, Denton.

Henderson, J.

2001 Excavations at the Rainey Site (41BN33), A Late Prehistoric Sinkhole Site in Bandera County, Texas. Report 5. Environmental Affairs Division, Archeological Studies Program, Texas Department of Transportation, Austin. 
Henry, D. O., F. E. Kirby, A. B. Justen, and T. R. Hays

1980 The Prehistory of Hog Creek: An Archaeological Investigation of Bosque and Coryell Counties, Texas. Laboratory of Anthropology, University of Tulsa, Tulsa.

Hester, T. R.

1989 Perspectives on the Material Culture of the Mission Indians of the Texas-Northeastern Mexico Borderlands. In Columbian Consequences, Volume 1: Archaeological and Historical Perspectives on the Spanish Borderlands West, edited by D. H. Thomas, pp. 213-229. Smithsonian Institution Press, Washington, D.C.

Hester, T. R. and R. C. Parker

1970 The Berclair Site: A Late Prehistoric Component in Goliad County, Southern Texas. Bulletin of the Texas Archeological Society 41:1-23.

Highley, C. L.

1986 Archaeological Investigations at 41LK201, Choke Canyon Reservoir, Southern Texas. Choke Canyon Series, Volume 11. Center for Archaeological Research, The University of Texas at San Antonio.

Highley, C. L. and D. Lenefeld

1977 Preliminary Investigations at the Wolf Site, Blanco County, Texas. La Tierra 4(4):16-19.

Hoffman, M. P.

1967 Ceramic Pipe Style Chronology Along the Red River Drainage in Southwestern Arkansas. The Arkansas Archeologist 8(1):4-14.

Inman, B. J., T. C. Hill, Jr., and T. R. Hester

1998 Archeological Investigations at the Tortuga Flat Site (41ZV155), Zavala County, Southern Texas. Bulletin of the Texas Archeological Society 69:11-33.

Jackson, A. T.

1938 The Fall Creek Sites and Reconnaissance in the Basin. In Annual Report of WPA and the University of Texas Archaeological Research, Lake Buchanan, 1936-1937, edited by J. E. Pearce, pp. 11-118. Anthropological Papers Vol. 3(1). University of Texas at Austin.

Jelks, E. B.

1953 Excavations at the Blum Rockshelter. Bulletin of the Texas Archeological Society 24:189-207.

1962 The Kyle Site: A Stratified Central Texas Aspect Site in Hill County, Texas. Archaeology Series 5. Department of Anthropology, University of Texas at Austin.

1970 Appendix B: Documentary Evidence of Indian Occupation at the Stansbury Site (41-39B1-1). Bulletin of the Texas Archeological Society 41:277-286.

2017 Archeology vs. History. Bulletin of the Texas Archeological Society 88:1-2.

Jensen, H. F., Jr.

1967 The Gas Plant Site. In A Pilot Study of Wichita Indian Archeology and Ethnohistory, assembled by R. E. Bell, E. B. Jelks, and W. W. Newcomb, pp. 45-50. Final Report for Grant GS-964. National Science Foundation, Washington, D.C. 
John, E. A. H.

1975 Storms Brewed in Other Men's Worlds, The Confrontation of Indians, Spanish, and French in the Southwest, 1540-1795. Texas A\&M University Press, College Station.

Johnson, L., Jr.

1994 The Life and Times of Toyah-Culture Folk as Seen from the Buckhollow Encampment, Site 41KM16, of Kimble County, Texas. Office of the State Archeologist Report 38. Texas Department of Transportation and Texas Historical Commission, Austin.

Jones, R. S.

2009 Archeological Survey and Testing at Lake Whitney, Bosque and Hill Counties, Texas. Ecological Communications Corporation, Austin.

Karbula, J.

2003 The Toyah Bluff Site (41TV441): Changing Notions of Late Prehistoric Subsistence in the Blackland Prairie Along the Eastern Edge of the Edwards Plateau, Travis County, Texas. Bulletin of the Texas Archeological Society 74:55-81.

Kehl, C.

1987 Urban Archaeology: Pepper Creek Watercourse, Temple, Bell County, Texas. Master's thesis, Department of Anthropology, Baylor University, Waco.

1990 Radiocarbon Dates from Pepper Creek Sites, Temple, Bell County, Texas. Texas Archeology 34(2):8.

Kelley, J. C.

1986 Jumano and Patarabueye Relations at La Junta de los Rios. Anthropological Papers No. 77. Museum of Anthropology, University of Michigan, Ann Arbor.

Kenmotsu, N. A. and J. W. Arnn III

2012 The Toyah Phase and the Ethnohistorical Record: A Case for Population Aggregation. In The Toyah Phase of Central Texas: Late Prehistoric Economic and Social Processes, edited by N. A. Kenmotsu and D. K. Boyd, pp. 19-43. Texas A\&M University Press, College Station.

Kenmotsu, N. A. and D. K. Boyd

2012 The Toyah Phase in Texas: An Introduction and Retrospective. In The Toyah Phase of Central Texas: Late Prehistoric Economic and Social Processes, edited by N. A. Kenmotsu and D. K. Boyd, pp. 1-18. Texas A\&M University Press, College Station.

Kibler, K. W.

2002 An Overview of Archeological and Paleoenvironmental Research Potential of Caves and other Karst Features at the Camp Bullis Military Reservation, Bexar and Comal Counties, Texas. Letter Report No. 531. Prewitt and Associates, Inc., Austin.

2012 The Role of Exotic Materials in Toyah Assemblages in a Late Prehistoric Economic and Social System. In The Toyah Phase of Central Texas: Late Prehistoric Economic and Social Processes, edited by N. A. Kenmotsu and D. K. Boyd, pp. 76-89. Texas A\&M University Press, College Station. 
Kibler, K. W. and C. J. Broehm

2005 Data Recovery at Site 41HM51, Hamilton County, Texas. Current Archeology in Texas 7(1):1822.

Krieger, A. D.

1946 Culture Complexes and Chronology in Northern Texas. Publication No. 4640. University of Texas, Austin.

Lakeman, J. B.

2001 An Analysis of the Ceramic Assemblage from Mission Espiritu Santo de Zuniga (41VT11), Victoria County, Texas. Master's thesis, Department of Anthropology, The University of Texas at Austin.

Locke, C. E.

1975 An Approach to X-Ray Diffraction Analysis of Prehistoric Ceramics. MS on file, Texas Archeological Research Laboratory, The University of Texas at Austin.

Long III, J. K.

1961 Three Central Texas Aspect Sites in Hill County, Texas. Bulletin of the Texas Archeological Society 30:223-252.

Lynott, M. J.

1978 Bear Creek Shelter. Archaeology Research Program, Southern Methodist University, Dallas.

1980 Hypothesis Testing and Historic Preservation at Bear Creek Shelter, Hill County, Texas. Bulletin of the Texas Archeological Society 51:209-241.

Mahoney, R. B. and S. A. Tomka

2001 National Register Eligibility Testing of 41 MM340 and 41MM341, along Little River, Milam County, Texas. Archeological Studies Program, Report No. 30, Environmental Affairs Division, Texas Department of Transportation, Austin, and Archaeological Survey Report No. 303, Center for Archaeological Research, The University of Texas at San Antonio.

Malof, A. F.

2001 Feast or Famine: The Dietary Role of Rabdotus Species Snails in Prehistoric Central Texas. Master's thesis, Department of Anthropology, The University of Texas at San Antonio.

2009 Site Stabilization at 41BL116, the Bowmer project. Texas Archeology 53(2):18-20.

Malof, A. F. and S. Evans

2016 Project 42. 15 T-120 Kendall to Fredericksburg Transmission Line Overhaul Project. In LCRA Annual Report of Cultural Resource Investigations for 2015, by D. J. Prikryl et al., pp. 619-627. Lower Colorado River Authority, Austin.

Marceaux, P. S.

2011 The Archaeology and Ethnohistory of the Hasinai Caddo: Material Culture and the Course of European Contact. Ph.D. dissertation, Department of Anthropology, The University of Texas at Austin. 
Mauldin, R. P. R. D. Greaves, J. L. Thompson, C. Munoz, L. Kemp, B. Meissner, B. Moses, and S. A. Tomka

2010 Archeological Testing and Data Recovery at 41ZV202, Zavala County, Texas. Report No. 21. Archeological Studies Program, Texas Department of Transportation, Austin, and Archaeological Survey Report No. 409. Center for Archaeological Research, The University of Texas at San Antonio.

Mauldin, R., J. Thompson, and L. Kemp

2012 Reconsidering the Role of Bison in the Terminal Late Prehistoric (Toyah) Period in Texas. In The Toyah Phase of Central Texas: Late Prehistoric Economic and Social Processes, edited by N. A. Kenmotsu and D. K. Boyd, pp. 90-110. Texas A\&M University Press, College Station.

Mehalchick, G. and K. W. Kibler

2008 Hunters and Gatherers of the North Bosque River Valley: Excavations at the Baylor, Britton, McMillan, and Higginbotham Sites, Waco Lake, McLennan County, Texas. Reports of Investigations No. 156. Prewitt and Associates, Inc., Austin.

Mehalchick, G., K. Killiam, S. C. Caran, and K. W. Kibler

2003 Geoarcheological Investigations and National Register Testing of 57 Prehistoric Archeological Sites on Fort Hood, Texas: The 1999 Season. Archeological Resource Management Series Research Report No. 44. United States Army Fort Hood.

Meroney, W. P.

1936 A Mass Burial near Waco. Bulletin of the Central Texas Archeological Society 2:39-60.

Miller, E. O. and E. B. Jelks

1952 Archeological Excavations at the Belton Reservoir, Coryell County, Texas. Bulletin of the Texas Archeological and Paleontological Society 23:168-217.

Mounger, M. A.

1959 Mission Espiritu Santo of Coastal Texas: An Example of Historic Site Archeology. Master's thesis, Department of Anthropology, The University of Texas at Austin.

Neff, H. and M. D. Glascock

2005 Compositional Variation in Aboriginal Ceramics from Central Texas: Results of Instrumental Neutron Activation Analysis. In Analysis and Reporting for 41FY135, the Sandbur Site, Fayette County, Texas, by A. J. Kalter, R. M. Rogers, and M. N. Smith, pp. C-5 to C-35. Archeological Studies Program Report No. 73. Texas Department of Transportation, Environmental Affairs Division, Austin.

Neureuther, R.

1984 A Pictograph Site on the Guadalupe River in Kendall County, Texas. La Tierra 11(3):2-11.

Newell, H. P and A. D. Krieger

1949 The George C. Davis Site, Cherokee County, Texas. Memoir No. 5. Society for American Archaeology, Menasha, Wisconsin. 
Nickels, D. L., C. B. Bousman, and J. L. Hurley (assemblers)

2010 An Archaeological Survey of 3,445 Acres at Camp Swift, Bastrop County, Texas. Archaeological Studies Report No. 11. Center for Archaeological Studies, Texas State University, San Marcos.

Odell, G. H.

2002 La Harpe's Post: A Tale of French-Wichita Indian Contact on the Eastern Plains. University of Alabama Press, Tuscaloosa.

Olds, D. L.

1965 Report on Materials from Brawley's Cave, Bosque County, Texas. Bulletin of the Texas Archeological Society 36:111-144.

Perkins, J. L.

1956 Tonk Creek Shelter. Central Texas Archeologist 7:41-47.

Perttula, T. K.

2001 Prehistoric Ceramic Sherds from 41MM341. In National Register Eligibility Testing of 41 MM340 and 41MM341, along Little River, Milam County, Texas, by R. B. Mahoney and S. A. Tomka, pp. 124-125. Archeological Studies Program Report No. 30. Environmental Affairs Division, Texas Department of Transportation, Austin.

2002a Archaeological Evidence for the Long-Distance Exchange of Caddo Indian Ceramics in the Southern Plains, Midwest, and Southeastern United States. In Geochemical Evidence for LongDistance Exchange, edited by M. D. Glascock, pp. 89-107. Bergin and Garvey, Westport, Connecticut.

2002b Native American Ceramics. In Archaeological Investigations at the last Spanish Colonial mission established on the Texas frontier: Nuestra Senora del Refugio (41RF1), Refugio County, Texas, Volume I Archaeological Investigations, by C. L. Tennis, pp. 233-260. Archeological Studies Program, Report No. 39, Environmental Affairs Division, Texas Department of Transportation, Austin, and Archaeological Survey Report No.315, Center for Archaeological Research, The University of Texas at San Antonio.

2009a Bone-tempered Plain Ware Ceramic Sherds from 41BX254, 41BX256, and 41BX1628 along the San Antonio River, Bexar County, Texas. Report submitted to Ecological Communications Corporation, Austin.

2009b Analysis of the Aboriginal Ceramic Sherds from the Bowmer Site (41BL116) and the Bowmer 3 Site (41BL110), Bell County, Texas. MS on file, Archeological \& Environmental Consultants, LLC, Austin.

2011 The Ceramic Artifacts from the Lang Pasture Site (41AN38) and the Place of the Site within an Upper Neches River Basin Caddo Ceramic Tradition. In Archeological Investigations at the Lang Pasture Site (41AN38) in the Upper Neches River Basin of East Texas, assembled and edited by T. K. Perttula, D. B. Kelley, and R. A. Ricklis, pp. 145-320. Archeological Studies Program Report No. 129, Texas Department of Transportation, Environmental Affairs Division, Austin.

2012 An Analysis of the Aboriginal Ceramic Sherds from the Bowmer Site (41BL116) and the Bowmer 3 Site (41BL110), Bell County, Texas. Archeological Journal of the Texas PrairieSavannah 2:38-59. 
2013 Caddo Ceramics in East Texas. Bulletin of the Texas Archeological Society 84:181-212.

2015a East Texas Caddo Ceramic Sherd Database. Journal of Northeast Texas Archaeology 51:1-46.

2015b Caddo Ceramic Vessels from the Goode Hunt (41CS23) and Clements (41CS25) Sites in the East Texas Pineywoods. Special Publication No. 42. Friends of Northeast Texas Archaeology, Austin and Pittsburg.

2015c Bison Remains and Tools on East Texas and Northwest Louisiana Caddo Sites. Journal of Northeast Texas Archaeology 58:15-34.

2016a Caddo Ceramic Sherds from Leon River Valley Sites in Coryell County, Texas. Journal of Northeast Texas Archaeology 66:51-58.

2016b Prairie Caddo Sites in Coryell and McLennan Counties in Central Texas. Journal of Northeast Texas Archaeology 58:41-66.

2017a Documenting East Texas Caddo Pottery in Central Texas. The Newsletter of The Friends of the Texas Archeological Research Laboratory March 2017:4.

2017b (assembler) Specialized Ceramic Analyses of the George C. Davis Site (41CE19) Ceramic Assemblage, Cherokee County, Texas. Report of Investigations No. 146. Archeological \& Environmental Consultants, LLC, Austin.

2017c The Distribution of East Texas Caddo Pottery Found in Archaeological Sites in the General Central Texas Region. La Tierra 41:69-82.

2017d Caddo Landscapes in the East Texas Forests. Oxbow Books, Oxford, England.

2018 Ceramic Vessels and Other Funerary Objects in the H.R. Taylor (41HS3) Cemetery, Harrison County, Texas. Special Publication No. 46. Friends of Northeast Texas Archaeology, Austin.

Perttula, T. K. (editor)

1999 The Hurricane Hill Site (41HP106): The Archaeology of a Late Archaic/Woodland and earlyMiddle Caddoan Settlement in Northeast Texas. 2 Vols. Special Publication No. 4. Friends of Northeast Texas Archaeology, Austin and Pittsburg.

2005 Archeological Investigations at the Pilgrim's Pride Site (41CP304), a Titus Phase Community in the Big Cypress Creek Basin. 2 Vols. Report of Investigations No. 30. Archeological \& Environmental Consultants, LLC, Austin.

2008 Lake Naconiche Archeology, Nacogdoches County, Texas: Results of the Data Recovery Excavations at Five Prehistoric Archeological Sites. 2 Vols. Report of Investigations No. 60. Archeological \& Environmental Consultants, LLC, Austin.

Perttula, T. K. and J. R. Ferguson

2010 The Chemical Variation in Prehistoric and Early Historic Caddo Ceramics in Eastern Texas. In Studies on the Instrumental Neutron Activation Analysis of Woodland Period and Caddo Tradition Ceramics from Eastern Texas, compiled by T. K. Perttula, pp. 3-1 to 3-62. Special Publication No. 17. Friends of Northeast Texas Archaeology, Pittsburg and Austin. 
Perttula, T. K. and P. Marceaux

2018 The Lithic and Ceramic Artifacts from the Spradley Site (41NA206), Nacogdoches County, Texas. Special Publication No. 50. Friends of Northeast Texas Archaeology, Austin and Pittsburg.

Perttula, T. K. and R. Z. Selden, Jr.

2014 Ancestral Caddo Ceramics in East Texas. Journal of Northeast Texas Archaeology 48:9-58.

Perttula, T. K. and H. J. Shafer

2016 Another Look at the Urbankte Site (41CV26) in Coryell County, Texas. Journal of Northeast Texas Archaeology 66:47-50.

Perttula, T. K., S. A. Iruegas, and H. Neff

2003 Caddoan Pottery in Central Texas: Geochemical Analyses of Ceramics from Fort Hood and Vicinity. Research Report 51. Archeological Resource Management Series, U.S. Army, Fort Hood.

Perttula, T. K., D. G. Robinson, J. R. Ferguson, and M. D. Glascock

2010 Analysis of Aboriginal Ceramic Sherds. In National Register Testing at 41BQ285, Bosque County, Texas: FM 56 Bridge Replacement at the North Bosque River, by T. B. Griffith, K. W. Kibler, and D. K. Boyd, pp. 85-104. Archeological Studies Program, Report No. 101. Environmental Affairs Division, Texas Department of Transportation, Austin.

Prewitt, E. R.

1974 Archeological Investigations at the Loeve-Fox Site, Williamson County, Texas. Research Report No. 49. Texas Archeological Survey, The University of Texas at Austin.

1982 The 1982 TAS Field School, Rowe Valley, Texas. Texas Archeology 26(3):2-4.

1983a 1982 TAS Field School. Texas Archeology 27(2):7-8.

1983b Rowe Valley Revisited: The 1983 TAS Field School. Texas Archeology 27(3):2-4.

19841984 TAS Field School, Rowe Valley Site, June 9-17. Texas Archeology 28(2):14-16.

2012 Toyah: Reflections on Evolving Perceptions. In The Toyah Phase of Central Texas: Late Prehistoric Economic and Social Processes, edited by N. A. Kenmotsu and D. K. Boyd, pp. 181203. Texas A\&M University Press, College Station.

Prikryl, D. J., A. F. Malof, C. A. Hixson, and D. K. Utley

2010 An Intensive Cultural Resources Survey of the Lower Colorado River Authority's Proposed San Saba River Nature Park Project, San Saba County, Texas. In LCRA Annual Report of Cultural Resource Investigations for 2010, compiled by C. A. Hixson, pp. 141-210. Lower Colorado River Authority, Austin.

Quigg, J. M. and J. Peck

1995 The Rush Site (41TG346), A Stratified Late Prehistoric Locale in Tom Green County, Texas. Technical Report No. 816C. Mariah Associates, Inc., Austin. 
Reese-Taylor, K.

1995 Petrographic Analysis of Ceramic Thin Sections. In NRHP Significance Testing of 57 Prehistoric Archeological Sites on Fort Hood, Texas, edited by J. T. Abbott and W. N. Trierweiler, pp. E-1 to E-11. Research Report No. 34. Archeological Resource Management Series, United States Army Fort Hood.

Reese-Taylor, K., J. Hageman, and R. A. Ricklis

1994 Preliminary Paste Analysis of Ceramic Samples from the Mustang Branch Site (41HY209) and Barton Site (41HY202). In Archaic and Late Prehistoric Human Ecology in the Middle Onion Creek Valley, Hays County, Texas, by R. A. Ricklis and M. B. Collins, pp. 549-568. Studies in Archeology 19, 2 Vols. Texas Archeological Research Laboratory, University of Texas at Austin.

Rice, P. M.

1987 Pottery Analysis: A Sourcebook. University of Chicago Press, Chicago.

Richmond, J. A., W. L. Richmond, and J. W. Greer

1985 Texas Archeological Society Field Schools 1962-1982. Bulletin of the Texas Archeological Society 54:105-184.

Ricklis, R. A.

1995 The Ceramics of the Toyah Horizon and the Rockport Phase as Indicators of some Basic Sociocultural Patterns. Bulletin of the Texas Archeological Society 66:195-203.

1999 Archeological Testing at 41GD112, La Villa de la Bahia: An Early Historic Site in Goliad County, Texas. Studies in Archeology 34, Texas Archeological Research Laboratory, The University of Texas at Austin, and Archeology Studies Program, Report No. 15, Environmental Affairs Division, Texas Department of Transportation, Austin.

2000 Archaeological Investigations at the Spanish Colonial Missions of Espiritu Santo (41GD1) and Nuestra Senora del Rosario (41GD2), Goliad County, Texas. Coastal Archaeological Studies, Inc., Corpus Christi.

Ricklis, R. A. and M. B. Collins

1994 Archaic and Late Prehistoric Human Ecology in the Middle Onion Creek Valley, Hays County, Texas. Studies in Archeology 19, 2 Vols. Texas Archeological Research Laboratory, University of Texas at Austin.

Riemenschneider, L.

1996 The Davis Hackberry Spring Site (41 $\left.{ }^{\text {ST}} 87\right)$, Sterling County, Texas. The Cache, Collected Papers in Texas Archeology, Volume 3:13-26.

Rogers, R. M. and T. K. Perttula

2005 Ceramics. In Analysis and Reporting for 41FY135, the Sandbur Site, Fayette County, Texas, by A. J. Kalter, R. M. Rogers, and M. N. Smith, pp. 201-216. Archeological Studies Program Report No. 73. Texas Department of Transportation, Environmental Affairs Division, Austin.

Rush, H. E., E. R. Prewitt, C. B. Bousman, and L. L. Bush

2015 Dating the Upper Toyah Component at Rowe Valley (41WM437) Or establishing A New Temporal Context for Subsistence and Site Use at Rowe Valley. Bulletin of the Texas Archeological Society 86:109-130. 
Saylor, R. H.

1974 An Archeological Report on the Trotter Site in Mills County. MS on file, Texas Archeological Research Laboratory, The University of Texas at Austin.

Scott, A. M., K. W. Kibler, and M. E. Blake

2002 National Register Testing of Nine Archeological Sites at Waco Lake, McLennan County, Texas. Reports of Investigations No. 132. Prewitt and Associates, Inc., Austin.

Schuetz, M. K.

1966 The Granburg Site: An Archaic Habitation in Bexar County, Texas. Studies 1. Witte Memorial Museum, San Antonio.

Shafer, H. J.

1969 Archeological Investigations in the Robert Lee Reservoir Basin, West Central Texas. Papers No. 17. Texas Archeological Salvage Project, University of Texas at Austin.

2006 People of the Prairie: A Possible Connection to the Davis Site Caddo. Archeological Studies Program, Environmental Affairs Division, Texas Department of Transportation and Prewitt and Associates, Inc., Austin.

2012 Miscellaneous Notes and Remembrances: Starting an Archaeological Career in Central Texas. $L a$ Tierra 39:39-52.

Shafer, H. J. and T. R. Hester

2014 The Legacy of Dee Ann Story. Bulletin of the Texas Archeological Society 85:9-30.

Shafer, H. J., D. A. Suhm, and J. D. Scurlock

1964 An Investigation and Appraisal of the Archeological Resources of Belton Reservoir, Bell and Coryell Counties, Texas: 1962. Miscellaneous Papers No. 1. Texas Archeological Salvage Project, The University of Texas at Austin.

Skelton, D. W.

1977 Archeological Investigations at the Fayette Power Project, Fayette County, Texas. Research Report No. 60. Texas Archeological Survey, The University of Texas at Austin.

Skinner, S. A. (assembler)

1972 The Natural and Cultural Environmental Resources of the Aquilla Creek Watershed, Hill County, Texas. Institute for the Study of Earth and Man, Southern Methodist University, Dallas.

Skinner, S. A. and J. Gallagher

1974 An Evaluation of the Archaeological Resources at Lake Whitney, Texas. Contributions in Anthropology No. 19. Southern Methodist University, Dallas.

Smith, F. T.

2000 The Wichita Indians: Traders of Texas and the Southern Plains, 1540-1845. Texas A\&M University Press, College Station.

Smith, J. E. II, J. C. Blaine, K. Gilmore, R. K. Harris, and I. M. Harris

1993 The Vinson Site (41LT1): A Norteno Focus Indian Village in Limestone County, Texas. Bulletin of the Texas Archeological Society 64:65-162. 
Smith, R. A.

1959 Account of the journey of Benard de la Harpe: Discovery made by him of several nations situated in the West. Southwestern Historical Quarterly 62(1-4).

Smith, V. J.

1936 The Pottery Horizons of Texas. Bulletin of the Texas Archeological and Paleontological Society 8:94-112.

Sorrow, W. M.

1970 Archeological Investigations at the Barker Site. Research Report No. 1. Texas Archeological Salvage Project, The University of Texas at Austin.

Sorrow, W. M., H. J. Shafer, and R. E. Ross

1967 Excavations at Stillhouse Hollow Reservoir. Papers of the Texas Archeological Salvage Project No. 11. Texas Archeological Salvage Project, The University of Texas at Austin.

Stephenson, R. L.

1970 Archeological Investigations in the Whitney Reservoir Area, Central Texas. Bulletin of the Texas Archeological Society 41:37-286.

Stokes, J. and J. Woodring

1981 Native-Made Artifacts of Clay. In Archeological Investigations at the George C. Davis Site, Cherokee County, Texas: Summers of 1979 and 1980, edited by D. A. Story, pp. 135-238. Occasional Paper No. 1. Texas Archeological Research Laboratory, The University of Texas at Austin.

Story, D. A.

1985 The Walton Site: An Historic Burial in McLennan County, Texas. Central Texas Archeologist 10:66-96.

1990a Cultural History of the Native Americans. In The Archeology and Bioarcheology of the Gulf Coastal Plain, by D. A. Story, J. A. Guy, B. A. Burnett, M. D. Freeman, J. C. Rose, D. G. Steele, B. W. Olive, and K. J. Reinhard, pp. 163-366. Research Series No. 38. Arkansas Archeological Survey, Fayetteville.

1990b Radiocarbon Assays. In The Archeology and Bioarcheology of the Gulf Coastal Plain, by D. A. Story, J. A. Guy, B. A. Burnett, M. D. Freeman, J. C. Rose, D. G. Steele, B. W. Olive, and K. J. Reinhard, pp. 658-733. Research Series No. 38. Arkansas Archeological Survey, Fayetteville.

2000 Introduction. In The George C. Davis Site, Cherokee County, Texas, by H. P. Newell and A. D. Krieger, pp. 1-31.2nd Edition. Society for American Archaeology, Washington, D.C.

Story, D. A. and H. J. Shafer

19651964 Excavations at Waco Reservoir, McLennan County, Texas. Miscellaneous Papers No. 6. Texas Archeological Salvage Project, University of Texas at Austin.

Story, D. A., B. Barber, E. Barber, E. Cobb, H. Cobb, R. Coleman, K. Gilmore, R. K. Harris, and N. Hoffrichter

1967 Pottery Vessels. In "The Gilbert Site: A Norteno Focus Site in Northeastern Texas," edited by E. B. Jelks. Bulletin of the Texas Archeological Society 37:112-187. 
Suhm, D. A.

1955 Excavations at the Collins Site, Travis County. Bulletin of the Texas Archeological Society 26:754.

1956 Archeological Excavations at the Collins and Smith Sites, Travis County, Texas. Master's thesis, Department of Anthropology, The University of Texas at Austin.

1957 Excavations at the Smith Rockshelter, Travis County, Texas. Texas Journal of Science 9(1):26-58.

Suhm, D. A. and E. B. Jelks (editors)

1962 Handbook of Texas Archeology: Type Descriptions. Special Publication No. 1, Texas Archeological Society, and Bulletin No. 4, Texas Memorial Museum, Austin. Reprinted in 2009, Gustav's Library, Davenport, Iowa.

Teltser, P. A.

1993 An Analytic Strategy for Studying Assemblage-Scale Ceramic Variation: A Case Study from Southeast Missouri. American Antiquity 58(3):530-543.

Thomas, G. B.

1978 A Survey and Assessment of the Archeological Resources of Fort Hood, Texas. Bulletin of the Texas Archeological Society 49:195-240.

Tomka, S. A.

n.d. Comparison of the Petrographic and INAA Analysis Results, 41HM51. MS on file, Prewitt and Associates, Inc., Austin.

Treece, A. C., C. Lintz, W. N. Trierweiler, J. M. Quigg, and K. Miller

1993 Cultural Resource Investigations in the O. H. Ivie Reservoir, Concho, Coleman, and Runnels Counties, Texas, Volume 4: Data Recovery from Ceramic Sites. Technical Report 346-IV. Mariah Associates, Austin.

Trierweiler, W. N. (editor)

1996 Archeological Testing at Fort Hood, 1994-1995. 2 Vols. Archeological Resource Management Series, Research Report No. 35. United States Army, Fort Hood.

Turner, R. L., Jr.

1997 Analysis of the Asa Warner (41ML46) Ceramics. Bulletin of the Texas Archeological Society 68:231-239.

Turner-Pearson, K.

2008 The Stone Site: A Waco Indian Village Frozen in Time. In "Land of Our Ancestors: Studies in Protohistoric and Historic Wichita Cultures," edited by T. G. Baugh and S. M. Perkins, pp. 565576. Memoir 40, Plains Anthropologist 53, No. 208. 
Ulrich, K. M.

2005 Formal, Technological, and Stylistic Analysis of Goliad Ceramics. In Archeological Investigations at Mission Espiritu Santo (41GD1), Goliad County, Texas, by K. M. Ulrich, A. L. Figueroa, J. L. Thompson, A. A. Fox, J. M. Hunziker, S. A. Tomka, and C. M. Munoz, pp. 41-50. Archeological Report No. 356. Center for Archaeological Research, The University of Texas at San Antonio.

2006 Native Ceramics from 41VT8. Bulletin of the Texas Archeological Society 77:123-130.

Valastro, S., Jr. and E. M. Davis

1970 University of Texas at Austin Radiocarbon Dates VII. Radiocarbon 12(1):249-280.

Veni, G., W. R. Elliott, A. M. Scott, R. S. Toomey III, and J. R. Reddell

1998 Hydrogeologic, Biological, and Archeological Investigations of Caves and Karst Features, and Continued Biological Monitoring of Four Edwards Limestone Caves, Camp Bullis, Texas. Report prepared for Prewitt and Associates, Inc., Austin. George Veni and Associates, San Antonio.

Voltin, J. E.

1996 Archaeological Testing of 41BL116. MS on file, Texas Archeological Research Laboratory, The University of Texas at Austin.

Walter, T. L.

2007 Espiritu Santo de Zuniga: A Frontier Mission in South Texas. University of Texas Press, Austin.

Walters, $\mathrm{M}$.

2006 The Lake Clear (41SM243) Site and Crotalus horridus atricaudatus. Caddoan Archeology Journal 15:5-41.

Watt, F. H.

1941 Preliminary Report on Potsherds from the Chupek Site. Newsletter 4:17-19. Central Texas Archaeological Society, Waco.

1941b Preliminary Report on Warner Site Number 2, Part I. Central Texas Archeological Society Newsletter, December, Part 3-III.

1942 Preliminary Report on Warner site Number 2, Part 2. Central Texas Archeological Society Newsletter, January, Part 3-IV.

1953 Pottery Diffusions of the Central Brazos Valley. Central Texas Archeologist 6:57-85.

1956 Archeological Materials from the Asa Warner Sites. Central Texas Archeologist 7:7-29.

1965 Notes on the Clark Site, McLennan County, Texas. Bulletin of the Texas Archeological Society 36:99-110.

1978 Radiocarbon Chronology of Sites in the Central Brazos Valley. Bulletin of the Texas Archeological Society 49:111-138.

Webb, C. H.

1959 The Belcher Mound, a Stratified Caddoan Site in Caddo Parish, Louisiana. Memoirs No. 16. Society for American Archaeology, Salt Lake City. 
Webb, C. H. and R. R. McKinney

1975 Mounds Plantation (16CD12), Caddo Parish, Louisiana. Louisiana Archaeology 2:39-127.

Weinstein, R. A. (editor)

2015 Archaeological and Geological Test Excavations at Site 41HM61, Hamilton County, Texas: Middle Archaic through Late Prehistoric Occupation in the Leon River Valley of Central Texas. Archeological Studies Branch Report No. 169. Environmental Affairs Division, Texas Department of Transportation, Austin.

Wright, J. F.

1997 The Asa Warner Site (41ML46), McLennan County, Texas. Bulletin of the Texas Archeological Society 68:215-261.

Young, D.

1988 An Osteological Analysis of the Paleoindian Double Burial from Horn Shelter, Number 2. Central Texas Archeologist 11:11-115. 


\title{
Appendix 1
}

\section{Megascopic and Ceramic Petrographic Analysis of a Prehistoric Caddo Sherd from Williamson County, Central Texas}

\author{
David Glen Robinson and Timothy K. Perttula
}




\section{Introduction}

A Caddo ceramic vessel sherd from Williamson County, Texas, was submitted for petrographic analysis by the senior author at the Texas Archeological Research Laboratory at The University of Texas at Austin (TARL) in 2017. The sherd came from an unrecorded site on private property near the San Gabriel River, and the avocational archaeologist that found the sherd brought the item to the attention of archaeologists. This approximate find spot of the sherd was well more than one hundred miles from the outskirts of conventionally delimited Caddo territory in Northeast Texas, and consequently the find held immediate interest for archaeological researchers. Analysis of the decorative elements on the sherd by Perttula identified the sherd as coming from an Early Caddo period (ca. A.D. 900-1200) Holly Fine Engraved ceramic vessel (Suhm and Jelks 1962:76-79) (see Figure 85, this volume). Further detailed analysis of the sherd could possibly indicate source areas in Caddo country or the alternative situation of local production of a ceramic vessel that closely resembles a Caddo vessel. The implications of the findings either way will illuminate issues of trade and transport of material culture items within and outside of the Caddo area of Northeast Texas.

\section{Geological Background}

Deposits along the San Gabriel River near the site are Quaternary in age, along with some Tertiary alluvial materials derived from the Cretaceous rock outcrops to either side and upstream on the river. Nearby lie the consolidated rocks of the Cretaceous Navarro Group. These rocks are largely undivided members of the Upper Taylor Marl and the Lower Taylor Marl, consisting of dense calcite deposits with abundant montmorillonitic clays and widely distributed rounded silt-sized quartz and rare glauconite, phosphate, pyrite, and hematite particles. Upstream, the widespread Cretaceous Austin Chalk has dense micro-granular calcite deposits with marine shell fossils, bentonite seams, and common pyrite nodules (Bureau of Economic Geology 1981).

\section{Methods}

\section{Megascopic Analysis}

Megascopic analysis is close examination of an artifact to identify relevant technical and cultural variables manifest in the artifact. In this case, the analysis relied on observation of the object with a stereoscopic binocular microscope in magnifications up to 10 power (10X). Colors were recorded by use of Munsell Color Charts.

\section{Petrographic Analysis}

The petrographic analysis applied the near-standard method of point counting 200 bodies or species in a thin section of the sherd prepared by National Petrographic Inc. of Houston (Chayes 1949; Shepard 1942, 1976). Point counting gives an accurate picture of the proportions of all the rocks, minerals, and voids in the section, as well as baseline information about the ceramic matrix of the vessel. The microscope work was conducted on an Olympus $\mathrm{OH} 2$ stereographic petrographic microscope at TARL.

\section{Results}

The megascopic analysis recorded variables of color, texture, and forms of decoration on the original sherd and vessel (Table A-1). The exterior surface is well burnished following the engraving of the design 
on the bottle sherd. The interior surface is roughened. Patches of grayish carbonate scale or caliche coating obscure parts of the sherd's interior surface.

Table A-1. Color recordings using Munsell Soil Color charts of the Williamson County sherd.

Sherd thickness

$7 \mathrm{~mm}$

Exterior surface colors (interior surface colors same)

2.5YR6/4 light reddish-brown

2.5YR5/4 reddish-brown

Core colors - thick carbon streak

5YR6/1 gray

5YR5/1 gray

The sherd core is taken up by a wide carbon streak. The paste texture is rough to slightly rolling. The paste also has a very fine silt component, likely resident in the original clay. Additional particles include medium sand-sized angular gray and black bodies, probably pieces of grog temper. There are also white, red, and black sub-rounded particles that may be additional tempering (bone particles). Altogether the matrix and the aplastic inclusions look strongly like Caddo ceramic pastes found on sites in Northeast Texas.

The petrographic analysis even more closely aligns the sherd with Caddo ceramics (Table A-2). The paste is moderately silty with rounded to very angular quartz silt, and it is tempered with bone and grog. The grog itself is tempered with quartz temper, with the exception of one particle that also contains a fine sand-sized particle of bone. Bone temper, the white particles identified in the megascopic analysis, ranges in size from medium sand to very coarse sand, and its colors under plane-polarized light are blue, turquoise, and brown. Minor minerals include common quartz, composite quartz, felsite (i.e., a generic term for many types of light-colored felsic fine-grained rock), and iron stain. This last body is a class of iron oxide, technically a soft form of hematite, that appears in the section as rounded, small, fine sand masses with blurry, indistinct edges, that give the material the look of a dye stain on the paste. Two voids had organic material in them, but they lacked dark rims around the voids. Mica, a very common regionwide marker for some Caddo pottery, is lacking in the section. Feldspar, an occasional telltale mineral, is also absent from the section.

Table A-2. Ceramic petrography of a Williamson County Caddo sherd: proportions of a 200 point count.

\begin{tabular}{ll} 
Attributes & Value \\
\hline Sherd ID & Wlmnco1 \\
Color ppl & dark brown \\
Color xpl & black \\
Isotropy & isotropic \\
Matrix & 26 \\
Voids & 13 \\
Common quartz & 18.5
\end{tabular}


Table A-2. Ceramic petrography of a Williamson County Caddo sherd: proportions of a 200 point count, continued.

\begin{tabular}{ll}
\hline Attributes & Value \\
\hline Composite quartz & 1 \\
Bone temper & 5.5 \\
Grog temper & 6.5 \\
Fe-stain & 11.5 \\
Woody burnout & 1 \\
Felsite & 0.5 \\
\hline
\end{tabular}

\section{Distributional Analysis}

The sherd and its contents contrast strongly with the carbonate landscape and substrate geology on which it was found. The sherd lacked any carbonate minerals or rocks in its interior; the interior surface carbonate scale is a post-depositional addition as would be expected on a calcium-rich, caliche-producing landscape. The search for a locality of origin of the specimen must look outside the Williamson County region.

The most distinctive direct finding of the ceramic petrographic analysis is the combination of bone and grog temper. These co-tempers are not uniformly distributed across prehistoric ceramic assemblages in Texas. Crushed bone was used as a temper in the Caddo area, the prairie zone of North and Central Texas, and in West and Southwest Texas vessels. Grog temper (i.e., crushed sherds) was used commonly in the Caddo area, but not in the prairies or the Central, West, and Southwest regions of Texas. Typically, the finding of a grog-tempered ceramic in any of those areas is sufficient to define the sherd as being from a Caddo-manufactured vessel. Currently, wares routinely tempered with grog are not known in the western half of Texas. The combination of grog and bone temper is a rare combination, with intermittent distributions only in the Caddo area. It is not known definitively if grog temper and grog and bone temper are strictly non-native ceramic traits of prairie and western Texas peoples, but a few recent studies have brought forward some archaeological evidence that may be of use in determining this.

In a comparative study of 118 Leon Plain ware (western) sherds and 68 Caddo sherds, all studied by the petrographic method, Lori Barkwill-Love (2012:Table F4) reported a complete absence of grogtempered western sherds, but abundant grog temper in the Caddo sherds, along with frequent occurrences of bone/grog temper. Bone temper by itself was common in the western sherds.

In a smaller study of five sherds excavated from 41BQ285 on the North Bosque River in Bosque County, Robinson (2010) identified grog temper in a sherd identified as of Caddo manufacture beforehand because the sherd had an engraved decorative element. The other four sherds were western types similar to Leon Plain. The Caddo sherd also had a greenish-gray paste and higher amounts of hematite than the western sherds. The western sherds had prevailing red-brown paste colors and were tempered with varieties of crushed quartz. Interestingly, none of the five studied sherds contained bone temper. 
Iruegas (Perttula et al. 2003:23-31) conducted a petrographic analysis of 27 identified Caddo sherds collected from sites distributed across four Central Texas counties, all located southeast of Bosque County. Grog tempering was definitive of some of his paste groups, and organic materials including bone were common in the collection; presumably some of the bone was deliberate temper. The study was not comparative, focusing on Caddo sherds from Central Texas sites, and western, Leon Plain ceramics, were not examined.

Bone and grog temper are found as co-tempers in some sub-areas of the Caddo area of Northeast Texas, but not in others. Sites with considerable proportions of grog-bone temper are found in Smith, Rusk, Titus, Franklin, Panola, San Augustine, Delta, Marion, Harrison, Camp, and Nacogdoches counties, among others. With regard to bone temper alone, however, the use of burned animal bone for the temper of ceramic vessels is a distinctive characteristic of some Northeast Texas Caddo ceramic sherd assemblages, and most ceramic assemblages in the region have some bone-tempered sherds. However, sherd assemblages with high proportions ( $>40$ percent of the sherd assemblage) of bone temper are concentrated in only a few locales across Northeast Texas, most notably in the Toledo Bend Reservoir area along the middle Sabine River and in sites in the Angelina River basin. Bone-tempered sherds are not a notable feature of Caddo ceramic assemblages in the Neches, Big Cypress, Sulphur, or Red River basins (Perttula 2015).

Pre-A.D. 1400/1450 Caddo sites with a high proportion of bone temper are found only in a few areas in the middle Sabine River basin, including the Redwine site (41SM193). Late Caddo (ca. A.D. 14001680) sites and assemblages with high proportions of bone temper are found in one site in the Trinity River basin (41HE70, Story 1965), and in several sites in the mid-Sabine and Angelina River basins. In fact, these sites are part of a previously identified Late Caddo period bone-tempered and brushed ceramic tradition (Perttula 2011:Figure 6-71 and 2015:Figure 11). Historic Caddo sites (dating from ca. A.D. 1700-1830) with high percentages of bone temper use are known only in the upper and middle Sabine River basins, and in the lower Angelina River basin (Perttula 2015).

The combined megascopic and petrographic analysis reported here establishes the Williamson County sherd clearly as deriving from a Caddo ceramic vessel and not from a vessel of local Central Texas manufacture. However, a more precise determination of its point of origin in the Caddo area of East Texas awaits further research.

\section{References Cited}

Barkwill-Love, L.

2012 Appendix F. Petrographic Analysis of Leon Plain and Caddoan Ceramics. In Archeological Testing and Data Recovery at the Flatrock Road Site, 41KM69, Kimble County, Texas, by J. L. Thompson, R. P. Mauldin, S. A. Tomka, and E. Oksanen. Archeological Studies Program, Report No. 133. Texas Department of Transportation, Environmental Affairs Division, Archeological Studies Program. Austin, and Archaeological Survey Report No. 419. Center for Archaeological Research, The University of Texas at San Antonio.

Bureau of Economic Geology

1981 Geologic Atlas of Texas, Austin Sheet. The University of Texas at Austin.

Chayes, F.

1949 A Simple Point-Counter for Thin Section Analysis. American Mineralogist 34:1-11. 
Perttula, T. K.

2011 The Ceramic Artifacts from the Lang Pasture Site (41AN38) and the Place of the Site within an Upper Neches River Basin Caddo Ceramic Tradition. In Archeological Investigations at the Lang Pasture Site (41AN38) in the Upper Neches River Basin of East Texas, assembled and edited by T. K. Perttula, D. B. Kelley, and R. A. Ricklis, pp. 145-320. Archeological Studies Program Report No. 129, Texas Department of Transportation, Environmental Affairs Division, Austin.

2015 East Texas Caddo Ceramic Sherd Database. Journal of Northeast Texas Archaeology 51:1-46.

Perttula, T. K., S. Iruegas, and H. Neff

2003 Caddoan Pottery in Central Texas: Geochemical Analyses of Ceramics from Fort Hood and Vicinity. Archeological Resource Management Series, Research Report No. 51. United States Army, Fort Hood.

Robinson, D. G.

2010 Ceramic Petrographic Analysis of Five Pottery Sherds from Site 41BQ285, Bosque County, North-Central Texas. Appendix B in National Register Testing at 41BQ285, Bosque County, Texas, FM56 Bridge Replacement at the North Bosque River, by T. B. Griffith. Reports of Investigations No. 160. Prewitt and Associates, Inc., Austin.

Shepard, A. O.

1942 Rio Grande Glaze Paint Ware: A Study Illustrating the Place of Ceramic Technological Analysis in Archaeological Research. Contributions to American Anthropology and History 7(9). Carnegie Institution of Washington, Washington, D.C.

1976 Ceramics for the Archeologist. 8th printing. Publication 609. Carnegie Institution of Washington, Washington, D.C.

Story, D. A.

1965 The Archeology of Cedar Creek Reservoir, Henderson and Kaufman Counties, Texas. Bulletin of the Texas Archeological Society 36:163-257.

Suhm, D. A. and E. B. Jelks (editors)

1962 Handbook of Texas Archeology: Type Descriptions. 2009 Reprint Edition. Texas Archeological Society, San Antonio. 